\title{
What Role Can an International Financial Centre’s Law Play in the Development of a Sunrise Industry? The Case of Hong Kong and Solar Powered Investments
}

\author{
Bryane Michael, University of Hong Kong \\ Simon Zhao, University of Hong Kong and \\ Dariusz Wojcik, University of Oxford
}

\begin{abstract}
How can international financial centres like Hong Kong increase assets under management - and thus their size and ranking? Most policymakers and their advisors wrongly answer this question by focusing on financial institutions, and the law that governs them. Instead, policymakers need to start by looking at actual markets. What new tastes and technologies need funding? How can such funding fit into already existing geographies of production, distribution and finance? In this paper, we show how a focus on funding sunrise industries can help increase assets under management for the financial institutions operating in an international financial centre like Hong Kong. We show using the specific example the photovoltaic (solar power) sector - how changes in financial law need to be contingent on market needs. We specifically show how legal changes which promote the securitisation of solar assets (and the sale of these securities) can help increase Hong Kong's financial institutions' assets under management. By using this specific case, we hope to provide insight into the broader question of how technological change, geography, and financial law interact.
\end{abstract}

JEL Codes: K22, G18, O44

Keywords: solar energy, cleantech, international financial centre, securitisation

This paper has been funded in part by a research grant from the University Grants Council as part of the project Promoting Hong Kong as an International Financial Centre. 


\section{Contents}

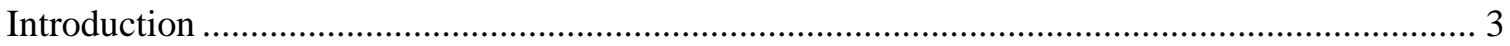

Financial Law as a Technology for Funding New Tastes and Technologies ................................ 5

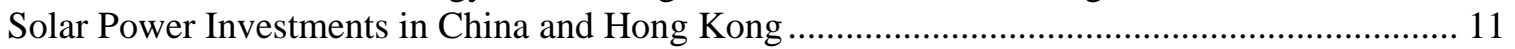

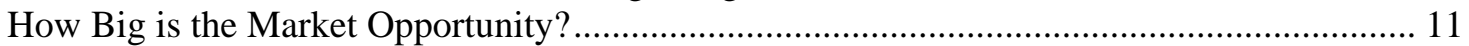

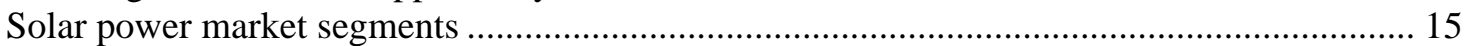

Solar power financing segments and the varieties of solar securitisation ................................. 18

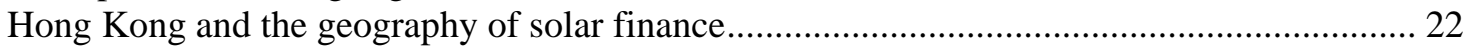

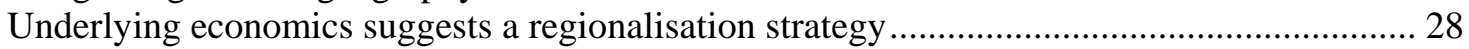

Securitising Mainland Solar Assets through Stocks, Bonds and More Exotic Securities ............. 32

Hong Kong attracts less interest from solar equity investors than expected............................ 32

Gains from packaging solar shares into Hong Kong mutual funds....................................... 38

Solar companies have enough debt to develop active bond and ABS markets....................... 42

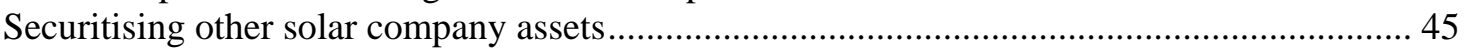

Hong Kong as a Mainland Solar Company Securitisation Centre ........................................... 52

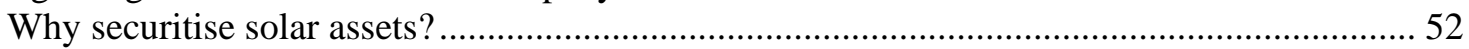

Lessons of the Minibond Scandal for Developing a Hong Kong Solar Market........................ 59

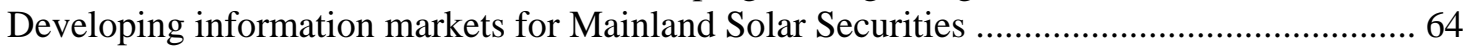

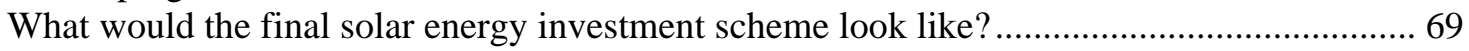

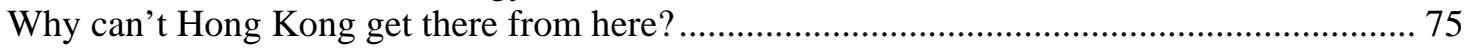

Financial Law in the Service of Demand for Sunrise Industry (and Solar) Securities.................. 77

Special purpose vehicles and issuers in asset-backed sunrise industry securities..................... 77

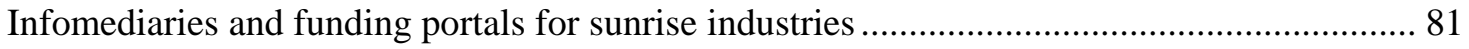

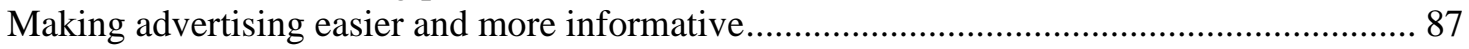

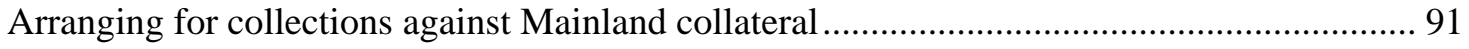

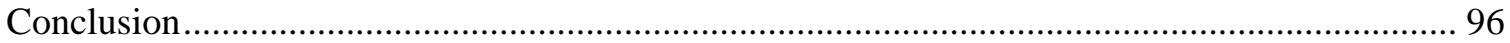

Appendix I: Solar Company Finance and the Financial Services Development Council's Business

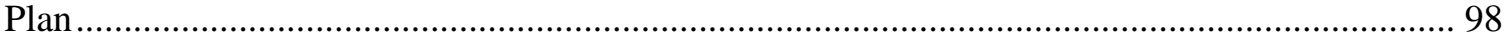

The FSDC should provide public goods which make solar securitisation possible.................. 98

Establishing and updating the web portal about investments in solar assets ........................... 99

Syndicating data to third-party users (like Yahoo) and developing online infomediaries ...... 100

Working with the Hong Kong Stock Exchange on webcast syndications ............................ 101

Underwriting the Bauhinia Solar Investment Fund and other securities................................ 102

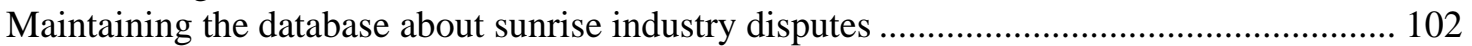

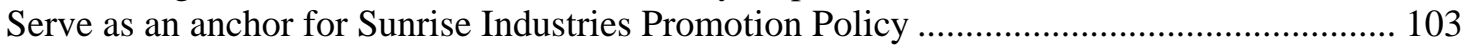

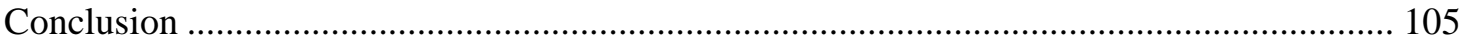

Appendix II: Regulatory Provisions Implementing a Sunrise Industries Promotion Policy ....... 106

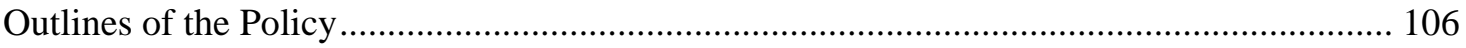

HKMA Statutory Guideline on Debt and Securities-Backed Instrument Reporting ............... 108

SFC Code on the Electronic Offer of Asset-Backed Securities in Sunrise Industries ............ 111

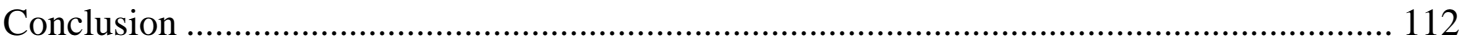




\section{What Role Can an International Financial Centre's Law Play in the Development of a Sunrise Industry? The Case of Hong Kong and Solar Powered Investments Bryane Michael, Simon Zhao and Dariuz Wojcik}

\section{Introduction}

International financial centres have traditionally emerged around new technologies. Booming industries in New York, Chicago, London, Paris and Berlin made the development of financial centres around those urban spaces important. Yet, many policymakers and their advisors focus on the financial institutions and financial flows themselves - rather than what those flows hope to accomplish. These policy advisors have forgotten the reason international financial centres - and the financial law which underpins them -- emerge in the first place. Their "structuralist" view of financial centre development sees financial centres emerging as the result of legal (and other institutional) change. Regulate the banks correctly, they argue, and the money will come. These policymakers, and their academic advisors, need to return to a more "contingency-based view" of financial centre development. Such a view sees financial law and international financial centre development revolve around the tastes and technologies they finance in the first place.

In such a contingency-based view, financial sector regulators focus on helping financial institutions fund existing and new tastes and technologies in the actual geographical spaces where those tastes and technologies lie. Such a view does not copy legal "best practice” or compare current financial flows with best-in-class financial centres. Such a view also does not even necessarily focus on the financial sector itself - through creating better and more efficient foreign exchange trading departments, tax incentives and rightregulating derivatives markets and so forth. Instead, such a view asks; where are savers and investors? How can the financial institutions operating in the international financial centre add value to the existing "geography of production, distribution and investment"? What competencies can these institutions provide - and thus add value?

In this paper, we illustrate how a focus on contingency-based financial law can potentially improve the competitiveness of an international financial centre like Hong Kong. We argue that financial law needs to actively encourage an international financial centre's financial institutions to seek out providers of funds to new technologies and facilitate the risk-adjusted value of such flows. ${ }^{1}$ We illustrate this view with the case of Hong Kong and the role its financial intermediaries can play in intermediating investments in local and Mainland-based solar-based (photovoltaic) energy generation technologies. We show how Hong Kong's financial law can respond to market needs, rather than simply rely on prescriptive advice focused at implementing "international best practice" or general advice focused on the financial sector itself. By showing several areas where a contingency-based view of financial law serves the objective of creating an

\footnotetext{
${ }^{1}$ We do not deny the important macroprudential role regulation needs to play. Instead, we argue that policies can serve macroprudential objectives also by encouraging financial intermediation in the economically and socially-beneficial production of goods and services (instead of just shifting money around, like in the Minibond case which we describe later).
} 
international financial centre better than a structuralist-based view, we hope to contribute to the larger debate about how to create and promote an international financial centre.

We organise the paper as follows. The first section positions our work in the broader debate about international financial centres - and the role that technological progress, geography and financial law play in the development of such centres. We argue against the increasing streak of "structuralist" analysis - which focuses on financial institutions themselves and the law that regulates them. The academic literature finds resoundingly for a contingency-based view of international financial centres. Their development traditionally has served to identify companies catering to new tastes and technologies and to efficiently deliver capital to these companies at a profit. ${ }^{2}$ The second section describes the solar energy market on the Mainland. We describe market segments and methods of financing investments in these segments in order to motivate the discussion on securitisation that follows. Stocks and bonds are just two methods, among many, of converting assets and liabilities into tradable securities. The third section describes the extent to which Hong Kong's financial institutions have succeeded in attracting money to the Mainland's solar energy sector. We argue that the lack of a contingency-based approach to financial regulation in Hong Kong has led to too little use of Hong Kong's capital markets to bring money to Mainland solar companies through equity, debt and other forms of finance. The fourth section describes Hong Kong's potential role in securitising Mainland solar companies' assets and liabilities. We describe why solar assets are particularly amenable to securitisation and why a contingency-based (or marketing) approach to financial regulation can help secure Hong Kong's place as an international solar securitisation centre. The fifth section describes the changes to Hong Kong's financial law needed to increase the depth of debt and asset securitisation. Some of these changes -- like to HKMA and SFC's rules -- focus on making marketing sunrise industry investments easier. Other changes, like changes in mediation reporting and the enforcement of civil judgments on the Mainland, make such investments safer. The final section concludes.

We should provide several caveats before we begin. First, we use an inductive rather than deductive method of argument - showing how a particular case (the finance of the Mainland's photovoltaic industry) shows us some something interesting about broader themes in international financial centre development (and the financial law that guides such development). Hong Kong provides a useful case study, as the city-state possesses a separate legal system from the Mainland. Such an arrangement provides for a useful "natural experiment" showing how technological change occurring across the Hong Kong-Mainland border affects the financial law of a jurisdiction quickly harmonising

\footnotetext{
${ }^{2}$ The reader with a background in marketing will recognise this statement as an adaptation of the standard definition of marketing. Banks market capital, and international financial institutions market capital internationally. Avlonitis et al. provide an empirically-based formulation of Philip Kotler's classic definition of marketing in a financial services context. Authors like Berger et al. have argued that bank regulation needs to take into account these important marketing aspects. See George Avlonitis, Paulina Papastathopoulou and Spiros Gounaris, An empirically-based typology of product innovativeness for new financial services: Success and failure scenarios, 18 J. OF PROD. INNOVATION MANAGE. 5, 2001. See also Allen Berger, Richard Herring, and Giorgio Szego, The role of capital in financial institutions, $19 \mathrm{~J}$. OF BANK. \& FIN. 3-4, 1995.
} 
with its wider nation-state. Second, we do not discuss the macroprudential aspects of financing solar energy projects on the Mainland. The Hong Kong government and many other scholars focus very heavily on managing financial system risks. ${ }^{3}$ In order to limit the size of our paper, we also avoid discussing other relevant issues related to our topic. Reducing taxation on capital gains and other benefits accruing from solar investments to foreigners (particularly US citizens), the development of insurance markets for solar energy, changes in Hong Kong's intellectual property rights regime to encourage $R \& D$, and regulations which make solar-related open-ended investment companies easier to establish represent some obvious areas of potential discussion. ${ }^{4}$ However, we avoid these topics to focus our paper on the topic at hand. Fourth (and finally) we refer to (and advocate) adopting US and UK experience -- an approach which appears more "structuralist" than "contingency-based." We refer to their experience to show how they adopted legal changes (like the Dodd-Frank Act or the CROWDFUND Act) to better match savers with companies. We do not argue that Hong Kong should follow these examples because they represent best practice. Instead, we provide concrete examples of laws to illustrate what changes to Hong Kong’s law might look like.

\section{Financial Law as a Technology for Funding New Tastes and Technologies}

International financial centres - at their heart - represent a technology for channelling capital from savers into growing economic sectors. ${ }^{5}$ Yet, many policymakers and their advisors lose sight of this basic principle as they seek to develop their own international financial centres. Figure 1 provides examples of reports offering advice to several current or aspiring international financial centres. These reports tend to follow three archetypical approaches in analysing an international financial centre's competitiveness and drawing conclusions based on such analysis. ${ }^{6}$ Following the first approach, many of these reports argue that macroeconomic conditions and conditions in specific financial markets help determine the depth/liquidity of specific financial sub-sectors (like debt, equity, derivatives and so forth). Reports by Deloitte and the World Bank on Moscow and Istanbul reflect most strongly this approach. ${ }^{7}$ Using the second approach, analysts assess

\footnotetext{
${ }^{3}$ For an overview, see Dong He, Hong Kong's Approach to Financial Stability, 9 INT'L J. OF CENTRAL BANKING 1, 2013, available online.

${ }^{4}$ Even citing these issues would require a lengthy footnote. For the reader interested in the general issues, see K.H. Solangi, M.R. Islam, R. Saidur, N.A. Rahim, and H. Fayaz, A review on global solar energy policy, 15 RENEW. \& SUSTAIN. ENERGY REV. 4, 2011.

${ }^{5}$ Several authors have commented on the need for international financial centres as a way of channelling savings from some countries toward investment opportunities in others. For a recent overview of thinking about this issue, see Philip Lane and Gian-Maria Milesi-Ferretti, The Drivers of Financial Globalization, 98 AMER. ECON. REV. 2, 2008.

${ }^{6}$ In practice, most reports include elements of all three approaches. These reports often also include a historical review of the development of other financial centres. As most academic authors rightly point out, the specific circumstances of each financial centre's development - and particularly its geography -- makes transplanting similar policies in other jurisdictions difficult. Indeed, leaving out the geographical parts of the analysis misses much of the reason for the development of an international financial centre in the first place. See Roger Lee and Ulrich Schmidt-Marwede, Interurban competition? Financial centres and the geography of financial production, 17 INT’L J. OF URBAN \& REGIONAL RES. 4, 1993.

${ }^{7}$ See Deloitte, Istanbul International Financial Centre Feasibility Study, 2007, available online. See also World Bank, Russian Federation Analysis and Diagnosis of the Financial, Regulatory and Institutional Policies Required for Becoming an International Financial Center, 2012, available online.
} 
legal provisions governing an international financial centre’s banks and broker-dealers and compare these provisions with other centres' law and/or best practice as promulgated by organisations like the Financial Stability Board. Mumbai’s and New York’s reports follow such an approach. ${ }^{8}$ In the third approach, writers focus on the broader aspects of a financial centre's competitiveness - like quality of life, trade facilitation and so forth. Authors then draw conclusions based on the centre's broader competitiveness. Assessments like Z/Yen's regular assessments of international financial centres and a recent Dubai report focus heavily on such an approach. ${ }^{9}$

\section{Figure 1: Advice on International Financial Centre Development Focuses on Centres Themselves Instead of their Target Markets}

\begin{tabular}{|c|c|c|c|}
\hline City & Focus of development as an international financial centre & Focus* & Link \\
\hline Mumbai & $\begin{array}{l}\text { Mumbai report focuses on Mumbai as a business process outsourcing } \\
\text { destination for other international financial centres' financial institutions. } \\
\text { Strategy adopted consists of looking at gap between other financial centres' } \\
\text { financial law (and other institutions) and Mumbai's. Also focuses on tax } \\
\text { policy and infrastructure. }\end{array}$ & $1 / 2$ & * \\
\hline Dubai & $\begin{array}{l}\text { Report focuses on quality of Dubai's various financial and business markets. } \\
\text { No consideration of what funding from/for an international financial centre } \\
\text { would actually be used for. }\end{array}$ & $1 / 3$ & $\stackrel{*}{-}$ \\
\hline $\begin{array}{l}\text { Hong } \\
\text { Kong }\end{array}$ & $\begin{array}{l}\text { Another gap analysis - comparing Hong Kong's various financial service } \\
\text { sub-sectors with what they could be. Analysis of general opportunities on the } \\
\text { Mainland, but no detailed discussion of specific markets. }\end{array}$ & $2 / 3$ & * \\
\hline Istanbul & $\begin{array}{l}\text { Provides overview of macroeconomic indicators, case studies from other } \\
\text { international financial centres and brief discussion of Istanbul's regulatory } \\
\text { and institutional "gap” with other centres. }\end{array}$ & $1 / 3$ & * \\
\hline Moscow & $\begin{array}{l}\text { This World-Bank led assessment provides perhaps the best example of an } \\
\text { analysis which analyses the depth and growth of various sub-sectors of a } \\
\text { financial services industry and provides recommendations in terms of } \\
\text { adopting international financial regulatory "best practice." }\end{array}$ & $1 / 2$ & * \\
\hline $\begin{array}{l}\text { New } \\
\text { York }\end{array}$ & $\begin{array}{l}\text { The report focuses on the country's national priorities and the way that the } \\
\text { development of New York, as an international financial centre, "fits" those } \\
\text { priorities. The solutions offered focus on legal (regulatory) changes - } \\
\text { without an analysis of the markets New York's financial institutions serve. }\end{array}$ & $2 / 3$ & * \\
\hline ma & $\begin{array}{l}\text { acroeconomics and the depth/liquidity of particular financial services sub-s } \\
\text { ocus on comparing existing regulation with an ideal as represented by othe } \\
\text { nendations by organisations like the Financial Stability Board, } 3=\text { focus on } \\
\text { conditions, like a qualified labour force, high quality of life, macroeconon }\end{array}$ & der & d \\
\hline
\end{tabular}

\footnotetext{
${ }^{8}$ See Indian Ministry of Finance, Report of the High Powered Expert Committee on Making Mumbai an International Financial Centre, 2007, available online. See also Bloomberg and Schumer, Sustaining New York's and the US' Global Financial Services Leadership, 2007, available online.

${ }^{9}$ See Z/Yen, The Global Financial Centres Index 14, 2013, available online. See also Stephen Thomas, Kamaldeep Panesar and Christina Makris, Dubai as an international financial centre: Threats and opportunities, 2013, available online.
} 
Such reports omit three aspects of international financial centre development which most long-term analysts of these centres (like academics) stress. First, most of these reports fail to use the traditional marketing analysis that the banks and broker-dealers in these centres might themselves use. ${ }^{10}$ Such an analysis would focus on customers, their demand for financial services and changes in tastes and technologies which create market opportunities. ${ }^{11}$ Second, an international financial centre develops as the result of a position in geographical space and located in a broader geography of social, trade, and financial networks. ${ }^{12}$ Surprisingly, most of the pundits we previously described fail to account for such a simple thing like geography. Third, these centres exist in broader systemic networks. Some financial centres remain small because they do not serve a vital role in bridging or bonding other centres together. ${ }^{13} \mathrm{By}$ analysing these centres directly (rather than the industries these centres finance), these pundits fail to see how their particular international financial centre contributes to a larger structure and flow of capital. ${ }^{14}$

The studies provided by the pundits ignore important findings from academic scholarship. Scholars have studied the nexus between financial centre development, technical innovation and legal change for a long time. As early as the $18^{\text {th }}$ century, policymakers knew that laws governing the way London and New York (among other places) financial institutions operated had to change with changing technologies. ${ }^{15}$ Railroads, enginedriven boats, electricity and steel required stock-holding organisational forms and larger banks to lend to these large industrial undertakings. ${ }^{16}$ The industrial revolution and future

\footnotetext{
${ }^{10}$ The financial services sector represents far more than simply banks and securities broker-dealers. We avoid discussing other organisations, insurance companies, in order to focus our paper. .

${ }^{11}$ Europe Economics' recent report on London as an international financial centre represents a welcome exception. See Europe Economics, The Value of Europe's International Financial Centres to the EU Economy, 2011, available online.

${ }^{12}$ We will describe many of these geographical features - in the specific context of solar company investment - throughout this paper. For an overview of the importance of these geographies, see Harry Garretsen, Michael Kitson and Ronald Martin, Spatial circuits of global finance, 2 CAMBRIDGE. J. OF REG., ECON., \& SOC 2, 2009.

${ }^{13}$ von Peter represents a prime example of such analysis. Yet, like many non-academic analysts of international financial centres, he focuses too much on the financial aspects of financial flows between these centres. He thus ignores the important real economy (and flows of goods and services) that these links supposedly support. See Goetz von Peter, International banking centres: a network perspective, 7 BIS QUART. REV. 4, 2007, available online.

${ }^{14}$ Tracing out global production networks, authors like Coe et al. show how international financial centres emerge and develop to foster the production, intermediation and consumption of new products. Such studies - in contrast to von Peter's -- represent good practice in analysing these centres. See Neil Coe, Karen Lai, \& Dariusz Wojcik, Integrating Finance into Global Production Networks, 48 REG. STUD. 5, 2014.

${ }^{15}$ As recently as the 1990s, scholars understood that technology and legal (among other) institutions change together. Authors like Nelson launched an entirely new literature in describing the "co-evolution" of technology, institutions, and international competitiveness. Unfortunately, without a legal background, Nelson had no way of analysing the institutions he described in the abstract. See Richard Nelson, Coevolution of Industry Structure, Technology and Supporting Institutions, and the Making of Comparative Advantage, 2 INT’L J. OF ECON. OF Bus. 2, 1995.

${ }^{16}$ See Simon Deakin, Legal origin, juridical form and industrialization in historical perspective: the case of the employment contract and the joint-stock company, 7 SocIO-ECON. REV. 1, 2009. See also Marco Da Rin \& Thomas Hellmann, Banks as Catalysts for Industrialization, 11 J. OF FIN. INTERMED. 4 ,2002. For a
} 
waves of innovation led to changes in banking, securities and corporate law. ${ }^{17}$ What lessons does the literature hold for thinking about the ways that Hong Kong's financial law can adapt in order to provide an attractive platform for capital going to new industries - like the Mainland's photovoltaic (solar) sector?

The literature divides into roughly five approaches of interest. Figure 2 shows the way we have roughly classified the literature. In the social network approach, authors look at the way that social relationships between innovators and financiers help determine the development of an industry. ${ }^{18}$ Many of these studies look at networks around successful geographically-defined areas, like Silicon Valley. ${ }^{19}$ Others look at biotech firms and Route $128 .^{20}$ Some studies look only at financial networks - but these are relatively rare. ${ }^{21}$ We use this approach later in our study to show how social relationships used to fund the Mainland's photovoltaic industry are bypassing Hong Kong.

\section{Figure 2: Most Academic Approaches to Thinking About the Nexus Between Technological Innovation, Financial Centre Development and Changes in Financial Law Look at the Way Legal Rules Are Contingent on Changes in Tastes and Technologies}

\begin{tabular}{l} 
View \\
Social Network \\
Approach \\
Comparative \\
Law and Finance \\
Approach \\
Endogenous \\
Growth \\
Approach \\
Clusters \\
Approach \\
\hline
\end{tabular}

Description

Summary: The flow of capital to new technologies depends on the social networks that inventors and bankers develop.

Methods: Social network analysis as the preferred method of analysis.

The law shapes financial centre and industrial sector development as much as these developments shape the law. Usually focuses on the incentives and institutions (as rules of the game) around particular statutes or provisions.

Methods: Game theory often preferred method of analysis

Summary: Focuses on the role of financiers in fomenting knowledge spill-overs and cluster formation. Heavy neo-classical economic focus.

Methods: Linear regression often the preferred method of empirical analysis.

Summary: Focuses on the way certain industrial clusters develop - usually as the result of the convergence of labour, capital, input and rival markets. Takes a business school approach.

Methods: Case studies often the preferred method of analysis.

more descriptive and historical view, see J. Bradford DeLong, Did J. P. Morgan's Men Add Value? An Economist's Perspective on Financial Capitalism, In Peter Temin, InsIDE THE BusINESS ENTERPRISE: HistORICAL PERSPECTIVES ON THE USE OF INFORMATION, 1991, available online.

${ }^{17}$ For a fuller description see Zorina Khan, Technological Innovations and Endogenous Changes In U.S. Legal Institutions: 1790-1920, NBER WP 10346, available online.

${ }^{18}$ For an overview of part of this literature, see Patricia Thornton and Katherine Flynn, Entrepreneurship, Networks, and Geographies, In Zoltan Acs and David Audretsch, HANDBOOK OF ENTREPRENEURSHIP RESEARCH, 2003.

${ }^{19}$ See Timothy Sturgeon, What really goes on in Silicon Valley? Spatial clustering and dispersal in modular production networks, 3 J. OF ECON. GEO. 2, 2003. See also Michel Ferrary \& Mark Granovetter, The role of venture capital firms in Silicon Valley's complex innovation network, 38 ECON. \& SoC. 2, 2009.

${ }^{20}$ See Walter Powell, Kenneth Koput, James Bowie \& Laurel Smith-Doerr, The Spatial Clustering of Science and Capital: Accounting for Biotech Firm-Venture Capital Relationships, 36 REG. STUD. 3, 2002. See also Steven Casper, How do technology clusters emerge and become sustainable?: Social network formation and inter-firm mobility within the San Diego biotechnology cluster, 36 RES. POL. 4, 2007.

${ }^{21}$ See Sabine Dorry, Luxembourg's specialisation as a financial centre within the global value networks of investment funds, CEPS/INSTEAD WP 2012-40, available online. 
Institutionalismof-Capitalism Approach
Summary: Often takes a historical approach - focusing on the way that particular events, persons, friendships and animosities shape the development of industries and the persons/institutions that finance them. These events shape the future rules-of-the game.

Methods: Historical analysis with a mix of political and legal analysis. Summary: Classical legal scholarship does not allow for the type of positive and predictive theorizing needed to develop a theory of technological, financial and legal change. As such, they focus on relatively narrow areas of financial law.

Methods: Legal analysis (sometimes with comparative law thrown in)

The comparative law and finance approach looks at the way legal rules of finance evolve in different jurisdictions. By choosing jurisdictions with differing economic and business sectors, the literature indirectly tells something about the way that differences in legal provisions correlate with (and possibly even affect) the development of economic sectors -- and visa-versa. Most of these studies deal with broad issues - like whether legal origin affects a particular type of finance (and thus the development of certain sectors or the entire economy). ${ }^{22}$ Some studies have recently looked at how differences in particular provisions from labour law, corporate law and civil/bankruptcy law across countries can impact on economic development and other factors. ${ }^{23}$ In this school, as in the others, legal change usually allows financial institutions to expand financing of activities previously over-regulated by financial law. ${ }^{24}$ We use tools from this approach as we later analyse parts of Hong Kong's securitisation rules which have resisted change to better serve investors and companies.

The endogenous growth approach focuses on the micro-level decisions of entrepreneurs to take money, and financiers' incentives to give it. Usually relying on game theoretic models, this approach often explains the simultaneous development of large-scale financial centres and entrepreneurial clusters from these micro-level interactions. Clustering (in terms of geographical distance, social distance or both) leads financial institutions to increase the flow of funds - through better assessing and pooling risks as well as matching profiles of payments and reimbursements to the revenue streams generated by the borrowers' (investees') businesses. ${ }^{25}$ Such clustering also allows for better information flow. ${ }^{26}$ Michalopoulos and co-authors in particular find a strong correlation between new sector development and changes in financial law as, "technological innovation and economic growth will eventually stop unless financiers innovate”. ${ }^{27}$ We use tools from this approach in later understanding how Hong Kong’s

\footnotetext{
${ }^{22}$ For an example, see Thorsten Beck, Asli Demirguc-Kunt and Ross Levine, Law and Firms' Access to Finance, 7 AM. L. \& ECON. REV. 1, 2005.

${ }^{23}$ See J. Armour, S. Deakin, P. Sarkar, M. Siems, and A. Singh, Shareholder protection and stock market development: an empirical test of the legal origins hypothesis, 6 J. OF EMPIR. LEG. STUD. 1, 2009.

${ }^{24}$ For an example and discussion, see Rainer Haselmann, Katharina Pistor and Vikrant Vig, How Law Affects Lending, 23 REV. FinANC. STUD. 2, 2010.

${ }^{25}$ For an example of such a study, see Thomas Hellmann, Laura Lindsey and Manju Puri, Building Relationships Early: Banks in Venture Capital, 21 REV. OF Fin. STUD 2, 2008.

${ }^{26}$ See Joseph Engelberg, Pengjie Gao, Christopher Parsons, Friends with money, 103 J. OF Fin. ECON. 1 2012.

${ }^{27}$ Their model, which relates most closely to our own question, shows that the rate of technological change depends on the rate of financial innovation. In other words, changes in the law governing the rate banks in a financial centre give money to talented entrepreneurs depends on market needs, not diffusion of "best
} 
financial institutions (and its law) have failed to respond to the development of solar panel clusters on the Mainland -- particularly around Shanghai and Shenzhen.

The institutionalism-of-capitalism approach focuses on the way that banks and other financial institutions have adopted to changes in tastes and technologies over time. Many studies focus on the way that financial capital shifts into growing sectors - and the way that such capital assists with the rapid rise of new industries. ${ }^{28}$ Financial institutions cluster together, partly to take advantage of a market too large for any one firm to handle - and partly because of agglomeration and/or network externalities. ${ }^{29}$ At the risk of over-generalising this large and complex literature, much financial innovation comes about as the result of changes in regulations - themselves affected by the needs of technological change. ${ }^{30}$ In a project perhaps closest to our own, Knox-Hayes looks at why London and New York serve as financial centres for emerging carbon markets. ${ }^{31}$ They find that "London and New York provide not only resources and financial infrastructure, but also institutional proximity that develops routines and practices between complementary firms." ${ }^{32}$ We use tools from this school of thought later in this paper to propose changes in Hong Kong's financial law.

The legal school looks at how technological innovation leads to changes in contracts and (in the common law jurisdictions) how court rulings shape the development of financial (banking and securities) as well as commercial (civil) law. Some legal innovations come from the resolution of these disputes which then become codified into law. ${ }^{33}$ Others are imported from abroad - with varying degrees of success. ${ }^{34}$ Unfortunately, following the

practice” or other "structuralist” methods. See Stelios Michalopoulos, Luc Laeven, Ross Levine, Financial Innovation and Endogenous Growth, NBER WP 15356, 2009. See also Anjan Thakor, Incentives to innovate and financial crises, 103 J. OF FIN. ECON. 1, 2012.

${ }^{28}$ For example, see Carlota Perez, TeChnOlogiCAl REvolutions And FinAnCiAl CAPITAL: THE DyNAMICS OF BuBBLES AND GOLDEN AGES, 2003.

${ }^{29}$ For an example looking specifically at Chinese financial services, see Lin Liang, Shanglang Lin, and Yong Li, How Agglomeration in the Financial Services Industry Influences Economic Growth: Evidence from Chinese Cities, DP 6, 2014, available online. Brulhart and Mathys argue against multi-industry clustering as causing the growth in financial services. They find -- at least in the European context -- that clustering in financial services results from scale effects which are independent of clustering in other sectors. See Marius Brulhart and Nicole Mathys, Sectoral Agglomeration Economies in a Panel of European Regions, 38 Reg. Sci. \& Urban Econ. 4, 2008, available online.

${ }^{30}$ For an example of a recent study, see W. Scott Frame and Lawrence White, Technological Change, Financial Innovation, and Diffusion in Banking, FBR OF ATLANTA WP 2009-10, available online.

${ }^{31}$ See Janelle Knox-Hayes, The developing carbon financial service industry: expertise, adaptation and complementarity in London and New York, 9 J. OF ECON. GEO. 6, 2009.

${ }^{32}$ Id at 1.

${ }^{33}$ See Christian Kirchner, Evolution of Law: Interplay between Private and Public Rule-Making - A New Institutional Economics-Analysis, 4 ERASMUS L. REV. 161, 2012. For an analysis about a new industry (the internet), see Gillian Hadfield, Delivering Legality on the Internet: Developing Principles for the Private Provision of Commercial Law, 6 AM LAW ECON REV 1, 2004. .

${ }^{34}$ Many scholars in the 1990s and 2000s obsessed about what factors made "legal transplants" (or laws copied from other jurisdictions) more successful. As more than a decade of evidence flows in, we still do not really know. All we know is that transplants work worse than hoped for. See Eirini Galinou, Legal Borrowing: Why Some Legal Transplants Take Root and Others Fail, 25 CoMP. LAB. L. \& POL'Y. J. 1, 2004. See also Jeremy Kingsley, Legal Transplantation: Is This What the Doctor Ordered and Are the Blood Types Compatible, 21 ARIZ. J. INT'L \& COMP. L., 493, 2004. 
legal approach, this school can only look at positive rather than normative factors in deciding on the desirability of legal change. ${ }^{35}$ We naturally use legal analysis when assessing the changes needed to make Hong Kong a more competitive centre for solar company securities finance. However, the school - reflecting the limits of the disciple -provides little normative theory to guide our recommendations. In this way, the legal school provides the closest basis for a "structuralist" analysis of international financial centres’ financial law.

In the following sections, we look at how changing Hong Kong's securitisation laws can help its financial institutions match foreign (US, EU, ASEAN and other) investors with Mainland. We review the current development of the Mainland's solar panel industry. We assess the extent to which Hong Kong-based financial institutions can help provide money to this industry (and sunrise industries like it). We specifically discuss how securitising this industry's assets and liabilities can provide a key way of channelling such finance. We also discuss how legal change can facilitate such securitised-based finance.

\section{Solar Power Investments in China and Hong Kong}

\section{How Big is the Market Opportunity?}

China represents one of the world's largest solar energy markets - potentially providing a revenue-generating bonanza for potential investors. ${ }^{36}$ Estimates of current solar (photovoltaic) production on the Mainland place the value China's solar industry at about $€ 37$ billion -- representing roughly $40 \%$ of the world's solar panel production. ${ }^{37}$ Geometrically extrapolating China's photovoltaic sector production at current growth rates leads to market sizes of at least $€ 100$ billion by $2017 .{ }^{38}$ Figure 3 shows several major solar projects on the Mainland - and key facts about installed and marginally added capacity. Unsurprisingly, much of this capacity has been brought online in the Western regions - far from China's traditional financial centres (like Beijing, Shanghai

\footnotetext{
35 "Positive" relates to what-is whereas "normative" relates to what should-be. For example, Vedder analyses EU renewable energy policy -- looking at how law constrains EU political and administrative support for renewable energies (like solar power). In the legal paradigm, no abstract factors (outside of values and existing law) drive policy recommendations. See Hans Vedder, EU Law and the Financing of New Energy Infrastructure, U. OF GRONINGEN RP 14, 2013, available online.

${ }^{36}$ Throughout this paper, we ignore the difficulties in obtaining the necessary permissions for solar projects. We assume that, over time, economic incentives will either drive investors to pay the costs of obtaining the relevant permissions, or encourage the Government to reduce the number of authorisations and rules governing solar exploitation. For an overview of the relevant rules on the Mainland, see Carolyn Dong and Stephen Webb, Solar PV projects in China, DLA PIPER BRIEF, 2013, available online.

${ }^{37}$ See Honghua Xu, Charlie Dou, Sicheng Wang, and Fang Lu, National Survey Report of PV Power Applications in China: 2011, IEA Rep., 2012, available online. We describe the value of consumption later in this paper.

${ }^{38}$ China's $12^{\text {th }}$ Five Year Plan backs up these extrapolations, planning for large increases in the production and consumption of solar power. See $12^{\text {th }}$ Five-Year Plan for the Solar Photovoltaic Industry, available online. For one of the many analysts that see such geometric growth occurring into the foreseeable future, see Arnulf Jager-Waldau, PV Status Report 2013, JCR SCIENTIFIC AND POLICY REPORT, 2013, available online.
} 
and Hong Kong). Provinces like Xingjian and Inner Mongolia have the largest amount of sun (as measured by mega-joules per meter-squared of solar panel surface). These also represent China's least financially developed regions. As such, China had to rely on financial centres to agglomerate and channel financial capital (money) for solarrelated tastes in these regions (and technologies going to these regions).

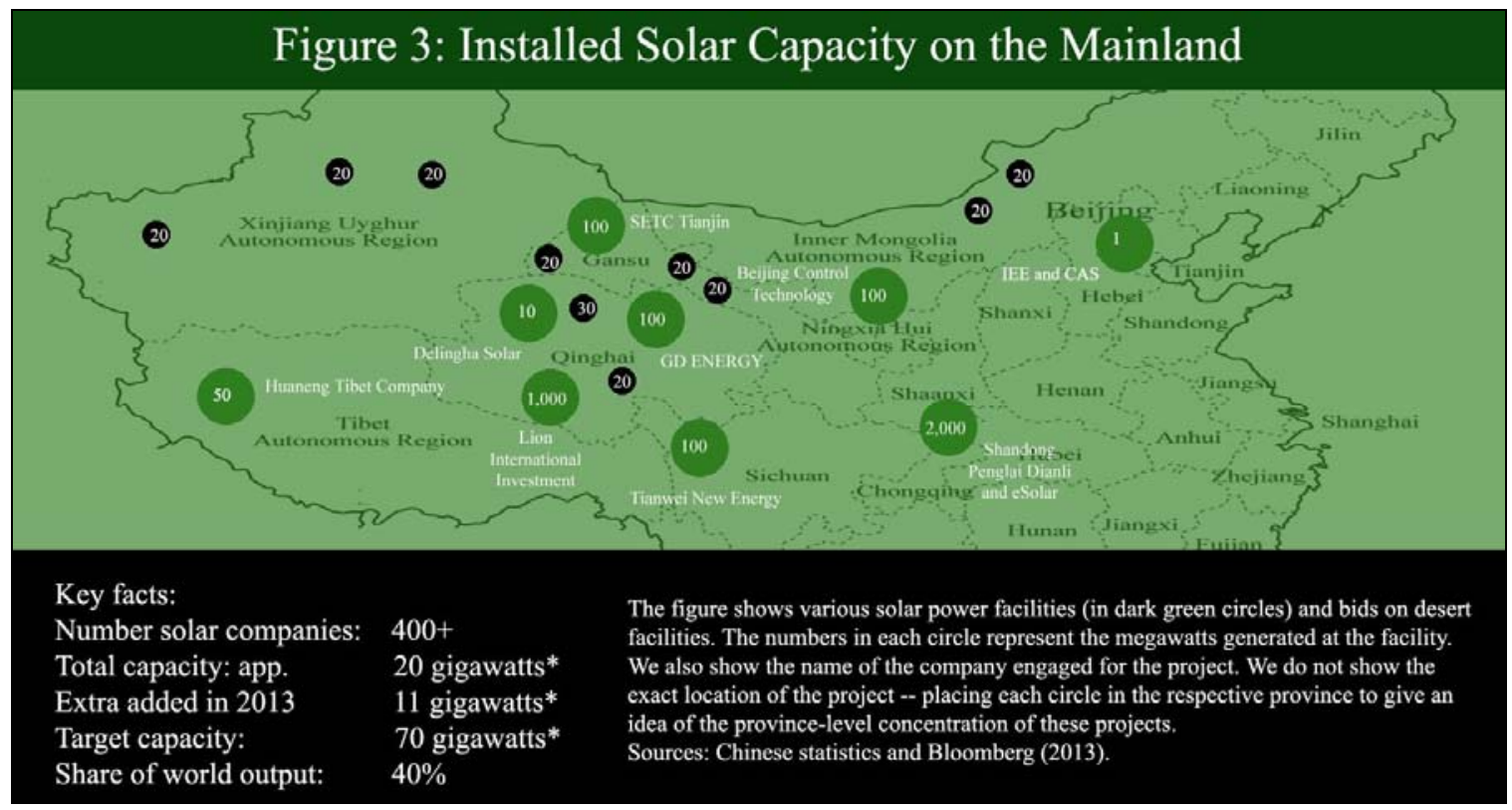

Chinese solar production represents a large and growing piece of a global industry. ${ }^{39}$ As shown in Figure 4a, Mainland solar production capacity has risen to about $40 \%$ of global photovoltaic cell production in 2012. ${ }^{40}$ Such market share has come at the expense mostly of German and Japanese producers. Roughly 31 gigawatts of solar power came online in 2012 - from solar panels using a variety of technologies to convert solar energy into electricity. Figure 4b shows the major technologies used, and Chinese producers' share of global production in the niches where its solar companies have a revealed comparative advantage. ${ }^{41}$ The US has a clear advantage in polysilicon - with $34 \%$ of global production. The Pacific Asia region (excluding China) produces 62\% of the world's TF modules. China exercises a dominant market position in three technologies wafers, C-Si cells and modules. Mainland companies like LDK Solar (which make polysilicon) may not have a global advantage (compared with the US). However, JA

\footnotetext{
${ }^{39}$ For an overview of the broader development of China's solar industry, see Mark Ng, Economic Impact of the Photovoltaic Industry in China After the Financial Crisis of 2009, 44 CHIN. ECON. 3, 2011.

${ }^{40}$ See Ranjit Deshmukh, Ranjit Bharvirkar, Ashwin Gambhir, and Amol Phadke, Changing Sunshine: Analyzing the dynamics of solar electricity policies in the global context, 16 RENEW. \& SUSTAIN. ENER. REV. 7, 2012, available online.

41 "Revealed comparative advantage" refers to cost advantages which we can not measure directly -- and thus must infer from gains in market share. For an econometrically derived analysis of such revealed comparative advantages in the photovoltaic space across countries, see Bernardina Algieri Antonio Aquino, Marianna Succurro, Going "green": trade specialisation dynamics in the solar photovoltaic sector, 39 ENERGY POL. 11, 2011.
} 
Solar (a global leader in the industry) does. ${ }^{42}$ Such production levels suggest that Chinese solar companies will have large financing needs into the foreseeable future.
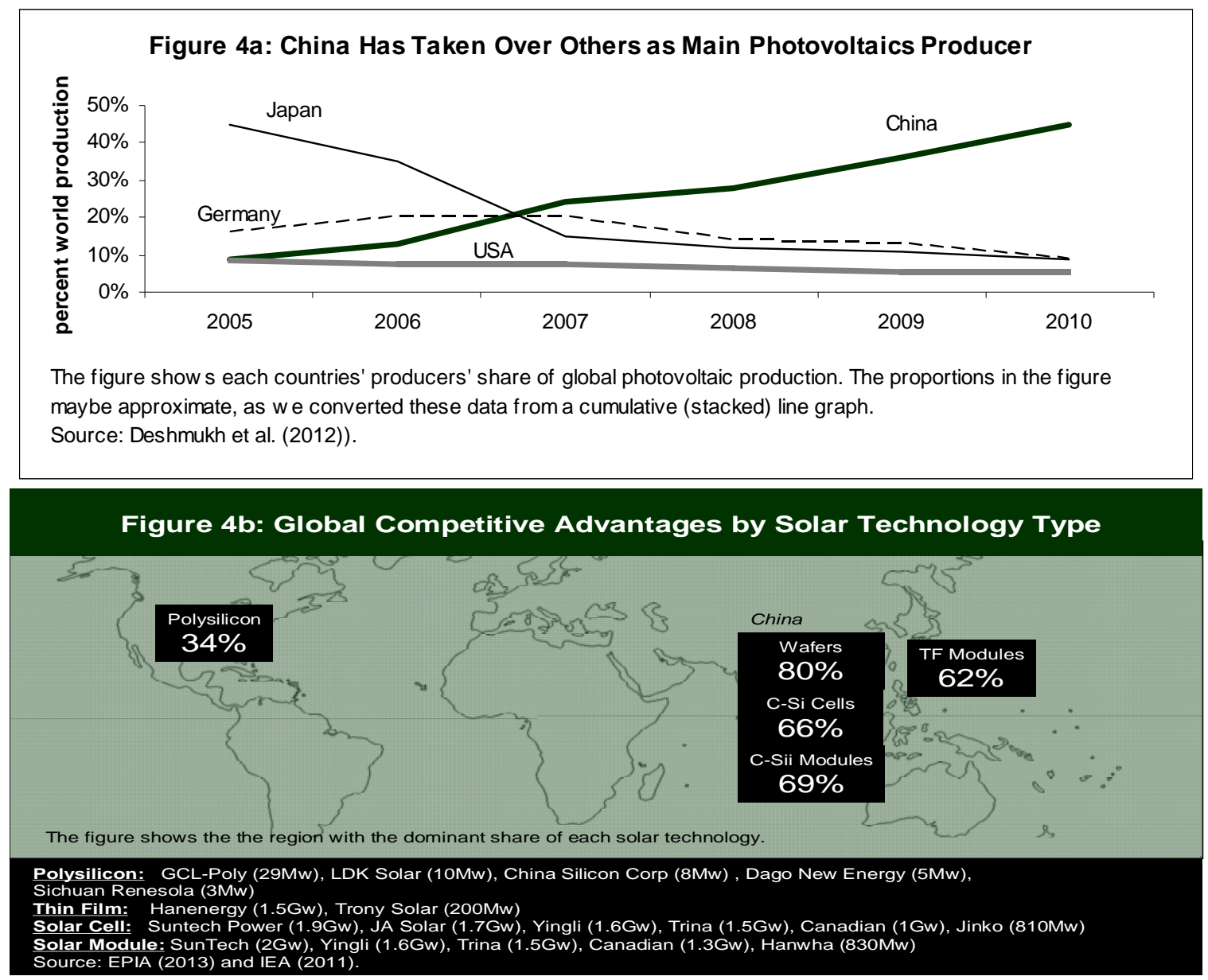

The Mainland's structure of solar panel exports also reveals several things about future expected national and international financial flows tied to solar consumption and production. Figure 5 shows China's main solar panel export markets (on the top panel) and Hong Kong's (on the bottom panel). First, the Dutch, Germans and Americans receive a large relative amount of solar cell imports from China. These flows suggest relatively constrained domestic solar cell production runs (at least compared with a world in which China does not export such large volumes and values of solar cells). ${ }^{43}$ In simpler terms, we will see less investment in Dutch, Germany and US producers (and thus markets) as money flows to Chinese producers. ${ }^{44}$ Second, Hong Kong possesses a

\footnotetext{
${ }^{42}$ For a detailed analysis of the Chinese photovoltaic market, see Thilo Grau, Molin Huo, Karsten Neuhoff, Survey of Photovoltaic Industry and Policy in Germany and China, DIW DP 1132, available online.

${ }^{43}$ Several studies show that reductions in Chinese imports would like constrain domestic solar consumption in places like the US. Burr, in particular, finds that a $25 \%$ tariff on Chinese solar imports chocks off supply and reduces consumption by US 30\%. See Chrystie Burr, Subsidies, Tariffs and Investments in the Solar Power Market, 2012, available online.

${ }^{44}$ As we mentioned in the previous footnote, lower Chinese production might actually also imply less US and other foreign production. In practice, we will observe both income and substitution (or trade creation
} 
solar industry of its own sufficiently integrated with the Mainland to provide a platform for solar industry related finance. Any cluster of financial institutions specialising in solar-industry related finance should draw on (and have local access to) individuals with specific knowledge in the field. The figure shows Hong Kong clearly has a relatively large "touch" to the solar panel industry -- be it indigenous or merely as a re-export market. Third, if the Mainland serves as Hong Kong's largest photovoltaic trading partner, its other markets (the US and Japan) represent a tiny fraction of these exports. Hong Kong has not developed any large and sustainable solar market of its own worth financing. Few opportunities exist to develop trade finance and other services for solar trade with other countries. Such numbers indicate that financial services aimed at sunrise industries like solar must be targeted abroad (and particularly at China).

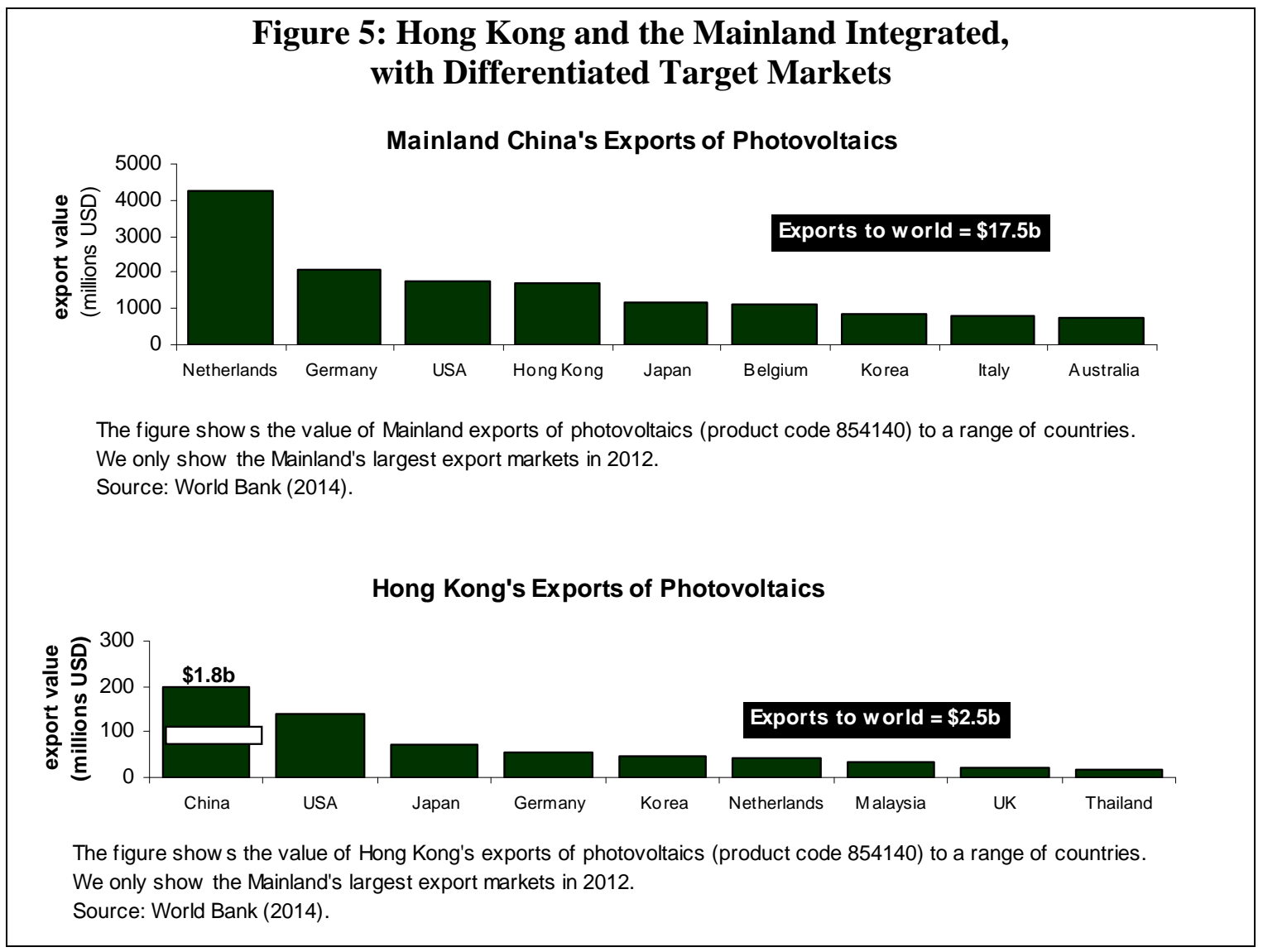

This pattern of development provides Hong Kong investors with potential opportunities. First, however deep China's pockets are - the Chinese Ministry of Science and Technology and other state-affiliated parties can not provide enough finance to meet all of production and distribution needs. Solar energy currently makes up less than $5 \%$ of all of China's electricity production. ${ }^{45}$ In order to achieve the government's pollution reduction, energy security and other policies, solar energy investments will need to

and diversion) effects as Dutch, Germany and US producers cater to an expanding market. We do not data to estimate the size of solar cell producers if China did not exist.

${ }^{45}$ See Furkan Dincer, The analysis on photovoltaic electricity generation status, potential and policies of the leading countries in solar energy, 15 REN. \& SUSTAIN. ENER. REV. 1, 2011. 
increase by at least another $€ 40$ billion. $^{46}$ If government financing enabled the first wave of solar energy generation on the Mainland, private sector investment must enable future waves. ${ }^{47}$ Second, the State-Owned Assets Supervision and Administration Commission will most likely eventually sell shares in China's state-owned solar companies (and even possibly the state power companies that distribute their power). ${ }^{48}$ Many publicly traded Chinese entities (both state-owned and completely privately owned) started as non-traded state-owned companies. ${ }^{49}$ Hong Kong investors will likely profit as privatisation spreads to China's state-owned solar companies as well as its grid power providers. ${ }^{50}$ Third, Hong Kong provides a potential beach-head for further investment on the Mainland. CLP Holdings - a Hong Kong power company - has investments on the Mainland and a market capitalisation of over HK\$160 billion. Three of the five major Chinese power companies have subsidiaries listed on the Hong Kong Stock Exchange. ${ }^{51}$ Hong Kong companies like CLP could provide useful partners and investors in China's lumbering solar giants. ${ }^{52} \mathrm{CLP}$, as an investment for foreign investors like US and EU funds, thus provides a potential conduit for further investment in Mainland solar.

\section{Solar power market segments}

The photovoltaic industry consists of a range of sub-sectors with their own production and financing needs. Figure 6 shows the various companies which contribute megawatts to each major part of the solar panel supply chain. ${ }^{53}$ Generally speaking, the production

\footnotetext{
${ }^{46}$ We rely on investment amounts per gigawatt to arrive at this estimate. For one of many sources providing information about capacity additions and the cost of adding such capacity, see REN21, Renewables 2014: Global Status Report, 2014, at Figure 14, available online.

${ }^{47}$ The Ministry of Science and Technology, China Development Bank and other government-affiliated bodies probably couldn't continue to offer subsidies and preferred access to capital even if they wanted to. Both US and EU authorities have complained and started to impose sanctions against Chinese photovoltaic manufacturers for receiving such benefits. See John Deutch and Edward Steinfeld, $A$ Duel in the Sun: The Solar Photovoltaics Technology Conflict between China and the United States, MIT REPORT, 2013, available online.

${ }^{48}$ At least, the trend has been to develop companies under partial or total state ownership of share capital, and then sell part or all of these shares. See Jean Chen, Determinants of capital structure of Chinese-listed companies, 57 J. OF Bus. REs. 12, 2004, available online.

${ }^{49}$ For more on China's build, operate and transfer approach to privatisation, see Henry Sanderson and Michael Forsythe, ChinA's SuPERBANK: DeBT, OIL AND InfLuENCE - How CHINA DEVELOPMENT BANK IS REWRITING THE RULES OF FINANCE, 2013.

${ }^{50}$ Liu provides an overview of China's electricity sector, while Nan and Moseley provide and prospects for further privatisation. See Zhenya Liu, EleCtRIC Power AND ENERGY IN CHINA, 2013. See also Yi-jia Nan and Mark Moseley, The Expansion of China's Generation Capacity, 1 PPP InsIGHTs 1, 2011, available online.

${ }^{51}$ China Power International Development, Huadian Power International Corporation, and Datang International Power Generation Company have Hong Kong listings. They represent independent power producing subsidiaries of larger non-traded state-owned enterprises.

${ }^{52}$ From the very limited publicly available data, we show later that Hong Kong institutional investors have tended to avoid large stakes in Mainland solar companies.

${ }^{53}$ See Thilo Grau, Molin Huo, and Karsten Neuhoff, Survey of Photovoltaic Industry and Policy in Germany and China, DIW WP 1132, 2011, available online. The schema we provide in this paper only represents the broadest generalisation of the inputs into solar panel production. For an excellent, detailed analysis of these inputs, their costs, and contributions to market prices (in the US context), see Jacob Funk,
} 
of solar panels requires four major value chain segments - silicon harvesting, the creation of silicon ingots and wafers, the creation of solar cells into modules, and assembly of modules into electricity-producing units. ${ }^{54}$ In China, silicon harvesting tends to involve a different set of companies than in the other parts of the supply chain. ${ }^{55}$ Potential investors in each segment of the supply chain have a range of companies to choose from. Investors interested in across-chain exposure might focus on Baoding and Trina. Investors interested in niche suppliers might focus on companies like Xinguang. Many of these companies do not trade on public exchanges - making private placement and asset securitisation investments the only ways of getting exposure to these companies.

\section{Concentrated competencies will need to be developed in an international financial centre to assess and price these investments.}

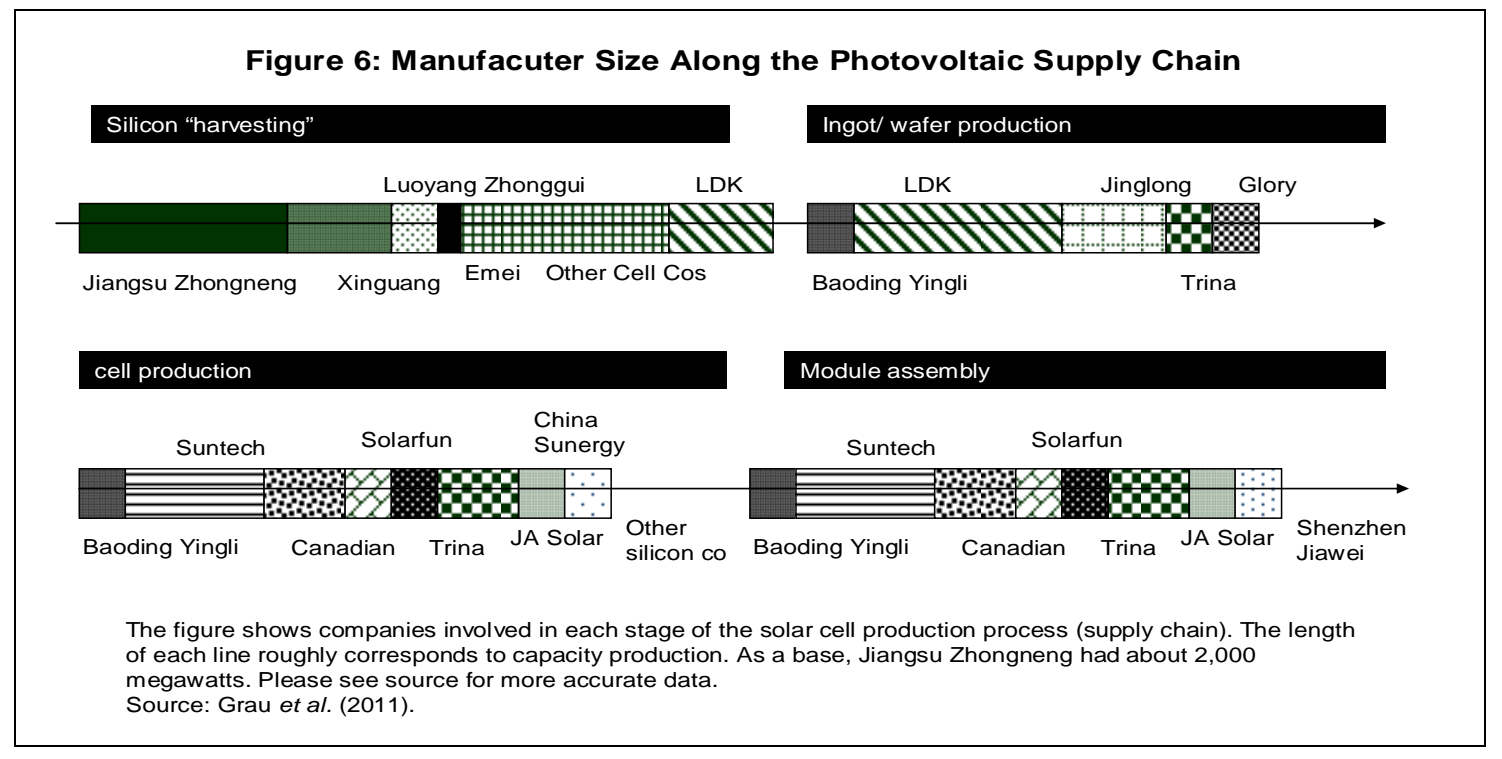

As many analysts have already pointed out, China's solar industry requires consolidation. Figure 7 shows the number of companies and employment in the major segments of China's photovoltaic supply chain. A large range of producers and suppliers occupy each segment of the supply chain - suggesting the need for consolidation. ${ }^{56}$ The Chinese photovoltaic industry employs easily over 6,000 workers - with many of these in "bloated” cells and ingots-wafers segments. ${ }^{57}$ Dropping prices and increasing debt

Kirkegaard, Thilo Hanemann, Lutz Weischer, and Matt Miller, Toward a Sunny Future? Global Integration in the Solar PV Industry, PIIE WP 10-6, 2010, available online.

${ }^{54}$ For a description of the process (and description of the market factors governing each step of the production process), see John Deutch and Edward Steinfeld, A Duel in the Sun: The Solar Photovoltaics Technology Conflict between China and the United States, MIT Report, 2013, available online.

${ }^{55}$ For an overview and contrasting perspectives from the US, see Michaela Platzer, U.S. Solar Photovoltaic Manufacturing: Industry Trends, Global Competition, Federal Support, CONGRESSIONAL RES. SERV. 75700 R42509, 2012, available online.

${ }^{56}$ Falling margins and increasing probabilities of default of Chinese photovoltaic manufacturers have been widely cited signs of overcapacity. See Wayne Ma, China to Promote Solar-Power Consolidation, WSJ DEC. 19, 2012, available online.

${ }^{57}$ For a description of such "bloating," see Abheek Bhattacharya, Clouds Shroud China's Bloated Solar Sector, WSJ MARCH 12, 2014, available online. 
burdens have represented clear signals of such a bloat. Yet, at the time of this writing, many analysts already believed much of the industry shake-up had already occurred. ${ }^{58}$

Figure 7: Major Players in a Piece of China's Photovoltaic Supply Chain

\begin{tabular}{|c|c|c|c|c|c|}
\hline Segment & silicon & $\begin{array}{l}\text { ingots and } \\
\text { wafers }\end{array}$ & cells & modules & a-Si \\
\hline $\begin{array}{l}\text { Company } \\
\text { (asterisks } \\
\text { mean a } \\
\text { dominant } \\
\text { player) }\end{array}$ & $\begin{array}{l}\text { Shuangliang* } \\
\text { Shanghai * } \\
\text { Morimatsu } \\
\text { Liaoning } \\
\text { Kaiyuan }\end{array}$ & $\begin{array}{l}\text { Beijing Hualin } \\
\text { CETC } 48 \\
\text { CETC } 2 \\
\text { Seven Star } \\
\text { CETC } 45 \\
\text { Jingyuantong* } \\
\text { Huasheng } \\
\text { Tianlong } \\
\text { Naitek } \\
\text { Hanhong } \\
\text { Crystal Growing } \\
\text { Boostsolar } \\
\text { Jinchen solar }\end{array}$ & $\begin{array}{l}\text { Beijing Hualin } \\
\text { CETC } 48 \\
\text { CETC } 2 \\
\text { Seven Star } \\
\text { CETC 45 } \\
\text { Langfang } \\
\text { Wanhe } \\
\text { Wuhan DR } \\
\text { Laser } \\
\text { Shenzhen SC } \\
\text { Exact } \\
\text { Equipment * } \\
\text { Qingdao } \\
\text { Sunred } \\
\text { Fulinfeng }\end{array}$ & $\begin{array}{l}\text { Beijing Hualin } \\
\text { Langfang } \\
\text { Wanhe } \\
\text { Shuangliang } \\
\text { Minitester } \\
\text { Shang } \\
\text { Technology } \\
\text { Solar Hope } \\
\text { Boost Solar } \\
\text { Jinchen Solar } \\
\text { Yuanguang }\end{array}$ & $\begin{array}{l}\text { Qingdao } \\
\text { Sunred } \\
\text { Beiyi } \\
\text { Innovation * } \\
\text { Polar PV* }\end{array}$ \\
\hline Total & 500 & 2200 & 1400 & 850 & 850 \\
\hline $\begin{array}{l}\text { Number in } \\
\text { Germany }\end{array}$ & $3 * *$ & $7 * * *$ & $10 * * *$ & 17 & -- \\
\hline
\end{tabular}

The figure shows employment in a range of companies comprising the Mainland's photovoltaic supply chain. We numbers are approximate (please see source for exact data). Companies with asterisks indicate they account for a relatively large proportionate share of employment in their sub-sector.

** indicates one firm has more than $90 \%$ of production capacity (measured in megawatts)

*** usually the same companies.

Source: Grau et al. (2011).

The development of Hong Kong as a solar-industry financial centre can help alleviate these problems in three ways. First, Hong Kong's “better” M\&A regulations could provide a forum for richer and prosperous firms to acquire failing firms. Many commentators have argued that the Chinese government plans to deal with the problem of over-capacity (and too many companies competing) by letting companies fail. ${ }^{59}$ By listing in Hong Kong and using its internationally-savvy financial institutions, many of these companies could merge, offer themselves for purchase and/or sell their assets and liabilities. ${ }^{60}$ Second, Hong Kong provides a ready-to-use English-language financial

\footnotetext{
${ }^{58}$ For a detailed analysis, include an analysis of the 180 companies most likely to exit the market, see Shyam Mehta, Global PV Module Manufacturers 2013: Competitive Positioning, Consolidation and the China Factor, 2012. For a popular media view, see Eric Ng, China's solar sector bounces back: Industry consolidation and soaring demand have helped mainland panel makers to return to profitability after a painful slump, SCMP 10 MARCH, 2014, available online.

${ }^{59}$ For one example, see Leslie Hook, Suntech clouds China solar sector outlook, FT 19 MARCH, 2013, available online.

${ }^{60}$ Estimates on credit and subsidies given to Mainland solar firms top $\$ 70$ billion in recent years. Reselling some of the non-collectible debt at a discount would help reduce the impact on China's already debt-burden budgets and possibly even allow for the continuation of economically-viable but highly indebted Mainland
} 
media ready to provide coverage and analysis of these companies - including a very active presence by Bloomberg and Reuters. Wide spread and in-depth reporting of publicly-traded companies might encourage solar company management to take more profitable pricing, debt-load, and other decisions. ${ }^{61}$ Third, only a deep and sophisticated financial centre can trade the complex structured and asset-backed securities the solar industry likely needs to use to develop. ${ }^{62}$ As we describe later, Hong Kong provides the best venue for developing specialised financial services for the companies occupying each segment of China's solar supply chain.

\section{Solar power financing segments and the varieties of solar securitisation}

The photovoltaic market consists of a range of suppliers, producers, intermediaries and complementary service providers that bring solar energy to final business and residential consumers. Figure 8 shows a partial value chain (more like an ecosystem) that would require financing from Hong Kong's financial institutions - both in China and potentially in other jurisdictions. ${ }^{63}$ The major segments include the R\&D companies which create the innovations that make solar power an increasing viable method of electricity generation, equipment manufactures (like solar cell and module producers), operations and maintenance companies and distributors (wholesalers and retailers). ${ }^{64} \mathrm{R} \& \mathrm{D}$ functions occur either in publicly funded bodies or often subsumed into the larger photovoltaic manufactures who can afford to fund large R\&D programmes. ${ }^{65}$ Increasingly, the market

photovoltaic firms. See Bloomberg, Chinese Zombies Emerging After Years of Solar Subsidies, BLOOMBERG SEPT. 9, 2013, available online.

${ }^{61}$ We say "might" because we could not find econometric studies assessing the effect of financial reporting on company managements' decisions. In theory, vibrant media coverage should help the market impose discipline on management. In practice, non-public insider information may provide a superiour basis for disciplining management. We discuss how to create such a more vibrant information market in Hong Kong later in this paper.

${ }^{62}$ Financing arrangements for the solar industry involve not only structured and other kinds of complex financial instruments, but supporting financial services like insurance. Hong Kong's already developed insurance markets provide a superiour platform for growing solar-industry related products. For the role of insurance in the solar industry, see Bethany Speer, Michael Mendelsohn, and Karlynn Cory, Insuring Solar Photovoltaics: Challenges and Possible Solutions, TECH. REP. NREL/TP-6A2-46932, 2010, available online.

${ }^{63}$ We underline "value" to highlight the difference between a value chain and a supply chain. We include finance provision as part of the value chain (though naturally not part of the supply chains we described in the previous section). For a US analysis, see Thomas Maslin, Strategic Analysis of the Downstream of the US Photovoltaic Value Chain, 2008, available online. For a China analysis, see also Tomoo Marukawa, The Compressed Development of China's Photovoltaic Industry and the Rise of Suntech Power, DPRIETI DP 12-E-051, available online.

${ }^{64}$ Mainland data suggest that integration across value chain segments helps increase gross profit margins which hover at about $20 \%$ over the range of Chinese photovoltaic producers. See China Greentech Initiative, CHINA' S SOLAR PV VALUE CHAIN, 2011, at 8.

${ }^{65}$ We do not describe the Chinese government's photovoltaic R\&D expenditures to keep this paper reasonable short. For a US perspective and description (in order to see where the sector might be heading), see Rosalie Reugg and Patrick Thomas, Linkages from DOE's Solar Photovoltaic R\&D to Commercial Renewable Power from Solar Energy, 2011, available online. See also Christian Breyer, Christian Birkner, F. Kersten, A. Gerlach, Jan Christoph Goldschmidt, G. Stryi-Hipp, D.F. Montoro, and Moritz Riede, RESEARCH AND DEVELOPMENT INVESTMENTS IN PV - A Limiting FACTOR FOR A FAST PV DifFUSION?, available online. 
is opening to small R\&D companies looking to receive patent licensing revenues. ${ }^{66}$ Equipment manufacturers (the part of the value chain we have spent the most space analysing) provide equipment for use at home and export abroad. Operations and maintenance companies oversee the installation and upkeep of these residential and industrial solar panels (and complexes). ${ }^{67}$ Solar panel providers deliver panels either to residential customers or to industrial size consumers, like utilities, that transfer electricity on to business and residential customers. ${ }^{68}$

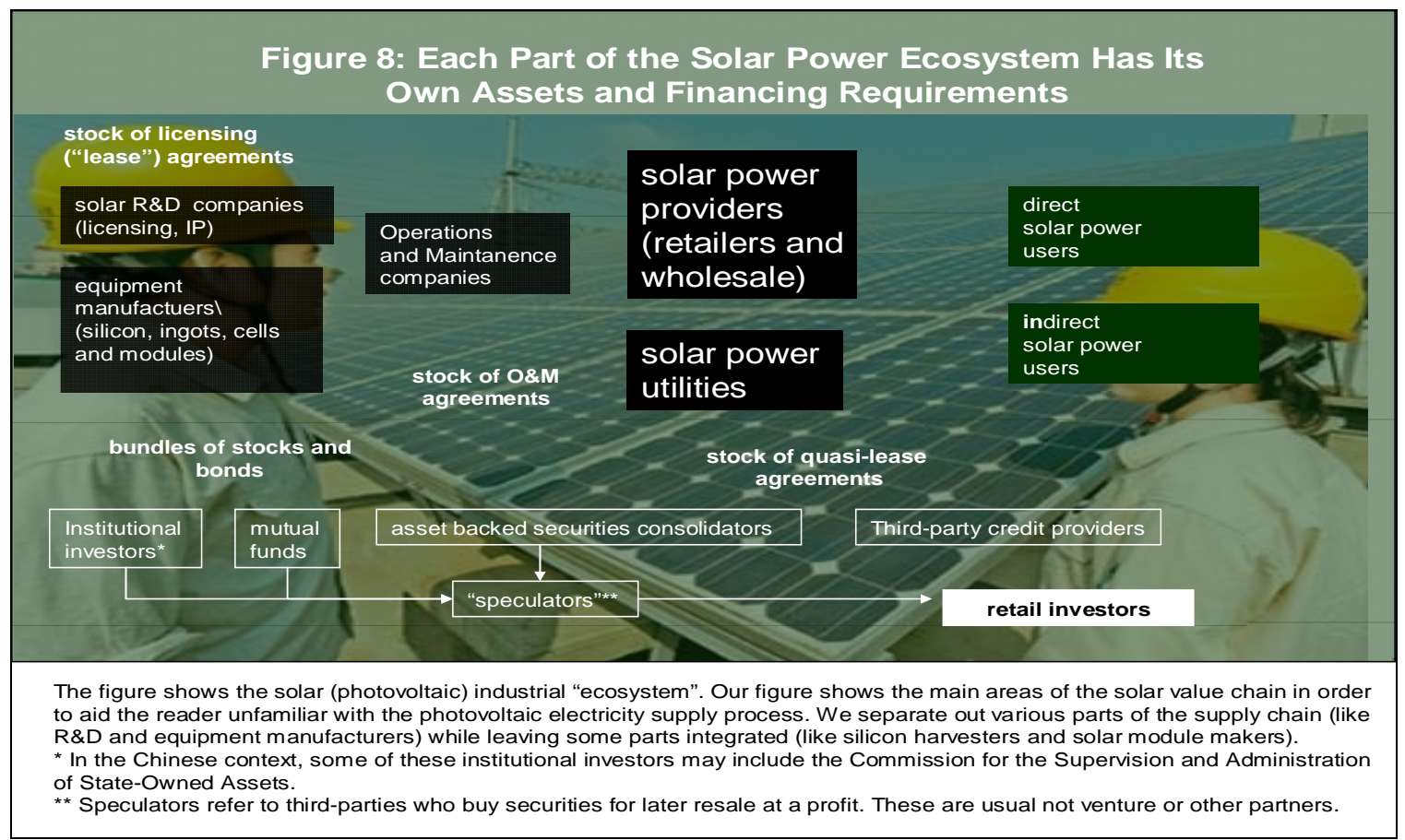

Within this ecosystem stand a number of financial intermediaries who provide funding. Institutional investors, mutual funds and banks/broker-dealers hold equity and debt in China's consolidated R\&D, manufacture, and operations/maintenance companies. ${ }^{69}$ In 2012 for example, roughly \$1 billion in new renewables investments appeared on the

\footnotetext{
${ }^{66}$ The solar R\&D industry represents an exciting and important future industry - where Hong Kong (and other) investors could fund firms similar to today's biotech firms which mainly develop patents. For an overview of this space, see Christian Breyer, Christian Birkner, Jan Meiss, Jan Christoph Goldschmidt, and Moritz Riede, A top-down analysis: Determining photovoltaics $R \& D$ investments from patent analysis and $R \& D$ headcount, 62 ENERGY POLICY 1, 2003.

${ }^{67}$ Operations and maintenance represent only one part of this industry. Companies like Europe-China Power (a Dutch subsidiary of Hanergy) provides project management and development consulting services. For an analysis of the industrial side of this market, see Cedric Brehaut, Megawatt-Scale PV Plant Operations and Maintenance: Services, Markets and Competitors 2013-2017, GTM Research, 2013. For a more general overview, see Nadav Enbar and Tom Key, Addressing Solar Photovoltaic Operations and Maintenance Challenges: A Survey of Current Knowledge and Practices, EPRI WP, 2010, available online. ${ }^{68}$ For an analysis of photovoltaic marketing channels in China and world-wide, see QYR Research Reports, Global and China Photovoltaic Solar Panel Industry 2014 Market Research Report, 2013.

${ }^{69}$ We provide data about these holdings in the next section. Broker-dealers hold most shares in the Mainland's solar companies on behalf of ultimate investors - making ultimate economic interests in these companies extremely difficult to ascertain.
} 
Shanghai Stock Exchange and \$100 million on the Shenzhen Exchange. ${ }^{70}$ These "bundles of stocks and bonds" (as we have labelled them in the figure) can stay in the hands of the institution or transfer to final owners who can represent other companies and retail investors. The other major part of the financing market includes various debt obligations and notes of credit as well as receivables (promises to pay for solar panels, maintenance and other goods and services). Particularly in the US, a side market in solar panel purchase and lease financing has begun to develop in order to provide funds to the consumer (rather than producer) side of the market. ${ }^{71}$ In the US, equity has accounted for about half of solar companies' finance - with private equity and venture capital comprising much of the remaining share. ${ }^{72}$ Even in the US, debt accounted for only about $10 \%$ of solar investment finance.

Each of these market segments can use a range of financial securities in order to raise funds and pass along risks. Figure 9 shows the range of securities which various companies in solar companies' value chains can use. Simple equities and debt (bonds) represent the most prosaic varieties of securities. However, other securities -- like assetbacked and debt-backed obligations) represent increasingly useful securities. As we describe later, because of Mainland solar companies' existing capital structures, debt instruments would likely swamp trade in equities. Most importantly, solar companies (and related solar finance companies) make excellent candidates for securitising their assets and liabilities and offering them directly. Such a direct offer provides investors with targeted exposure to the risks and returns on those assets (like a machine which presses silicon chips for example). Why buy equities which bundle all kinds of management, macroeconomic, operational and other risks, when investors can purchase directly securities which only give them risks-returns related to those silicon pressing machines?

\footnotetext{
${ }^{70}$ We could not obtain detailed information about the types of renewables (including solar) and the specific types of securities listed. See Frankfurt School-UNEP, Global Trends in Renewable Energy Investment 2013, 2013, available online.

${ }^{71}$ Increasingly, finance companies provide money to consumers looking to buy or lease solar panels. We do not describe this in much detail. For a US perspective, see Bethany Speer, Residential Solar Photovoltaics: Comparison of Financing Benefits, Innovations, and Options, NREL/TP-6A20-51644, 2012, available online. See also Jason Coughlin and Karlynn Cory, Solar Photovoltaic Financing: Residential Sector Deployment, NREL/TP-6A2-44853, 2009, available online.

72 See Charles Jennings, Robert Margolis, John Bartlett, A Historical Analysis of Investment in Solar Energy Technologies (2000-2007), NREL/TP-6A2-43602, 2008, available online.
} 


\section{Figure 9: Solar Market Funding Instruments and Maximum Contributions to Assets-Under-Management by Hong Kong Financial Intermediaries}

\begin{tabular}{|c|c|c|}
\hline $\begin{array}{l}\text { type of } \\
\text { security }\end{array}$ & areas of ecosystem & $\begin{array}{l}\max \\
\text { market } \\
\text { size for } \\
\text { HK }\end{array}$ \\
\hline $\begin{array}{l}\text { Common } \\
\text { stocks } \\
\text { (equities) }\end{array}$ & $\begin{array}{l}\text { For R\&D companies, O\&M providers, manufacturers as well as the finance } \\
\text { side (residential finance companies and banks providing loans to utilities), } \\
\text { stocks still represent the best "base" securitisation to provide access to these } \\
\text { companies’ underlying risks and returns. }\end{array}$ & $\$ 5 b$ \\
\hline $\begin{array}{l}\text { Preferred } \\
\text { stocks } \\
\text { (equities) }\end{array}$ & $\begin{array}{l}\text { For companies looking to pay steady income (and investors looking to } \\
\text { receive a steady stream) while giving away residual risks. Particularly suited } \\
\text { to solar retail distributors and utility providers. }\end{array}$ & $\$ 4 b$ \\
\hline Senior debt & $\begin{array}{l}\text { For investors looking for yield while reducing risks. All companies in } \\
\text { "ecosystem” will need to issue debt as part of optimal capital structure. }\end{array}$ & $\$ 2.5 b$ \\
\hline $\begin{array}{l}\text { Sub-ordinated } \\
\text { debt }\end{array}$ & $\begin{array}{l}\text { For savers looking for debt instruments which allow them to share company } \\
\text { risks (like equity holders). Need to pay higher yields attractive for risky } \\
\text { high-return new internal ventures. }\end{array}$ & $\$ 1.5 b$ \\
\hline $\begin{array}{l}\text { Commercial } \\
\text { paper }\end{array}$ & $\begin{array}{l}\text { Solar companies and solar finance companies will have relatively large very } \\
\text { short-term financing needs. Such paper can also serve as collateral in } \\
\text { repurchase markets. }\end{array}$ & $\$ 500 m$ \\
\hline $\begin{array}{l}\text { Asset (and } \\
\text { receivables)- } \\
\text { based } \\
\text { obligations } \\
\text { (asset-backed } \\
\text { obligations) }\end{array}$ & $\begin{array}{l}\text { Mainland solar companies have large amounts of receivables and assets (like } \\
\text { plant, property, IP and so forth). Such securities offer a better targeting of } \\
\text { risks/returns for R\&D license fees and residential and utility-level solar } \\
\text { payments. Why should investors hold stocks when they can get targeted } \\
\text { returns on these assets directly? }\end{array}$ & $\$ 9 b$ \\
\hline $\begin{array}{l}\text { Collateralised } \\
\text { debt } \\
\text { obligations }\end{array}$ & $\begin{array}{l}\text { Mainland solar companies have a fair amount of debt (both short-term and } \\
\text { long-term). Why should banks only be allowed to participate in receiving } \\
\text { returns on such debt? By hiving off such debt in tradable securities, } \\
\text { companies can lower borrowing costs. Investors get more targeted loans. } \\
\text { Best for solar equipment, O\&M equipment service providers and others } \\
\text { needing to "smooth" payments over time. }\end{array}$ & $\$ 5 b$ \\
\hline $\begin{array}{l}\text { Equity-linked } \\
\text { derivatives } \\
\text { and options }\end{array}$ & $\begin{array}{l}\text { Provides useful "state contingent" payoffs ideal for insurance and gambling } \\
\text { (for speculators). These derivatives and options can help normal equity and } \\
\text { debt investors hedge out risks (like buying puts on stock). }\end{array}$ & $\$ 60 \mathrm{~m}$ \\
\hline $\begin{array}{l}\text { insurance and } \\
\text { asset-credit } \\
\text { default swaps }\end{array}$ & $\begin{array}{l}\text { Solar manufacturers, distributors and even finance firms represent relatively } \\
\text { capital-intensive enterprises. Paying out } 1 \%-2 \% \text { of the value of assets for } \\
\text { insurance can protect from large-scale, low-probability risks. }\end{array}$ & $\$ 150 \mathrm{~m}$ \\
\hline
\end{tabular}

The figure shows various securities that companies in solar company producers' value chains can use to raise funds and pass-off risks. We show estimated maximum achievable market sizes for the securitisation of various Mainland solar companies' assets and liabilities, on the assumption that all equity, debt and securitisation of these assets and liabilities trade through Hong Kong intermediaries. We make numerous assumptions about investors' preferences for packaged securities in order allocate certain market sizes to particular classes of securities. For example, from the total value of equity finance (priced at market values in June 2014), we allocate part of that to preferred (rather than ordinary) shares based on assumptions about the overall market's risk aversion and desire for steady-stream payments.

Methodology: Our methodology consisted of the following. We obtained market valuations for all Mainland solar companies traded in Hong Kong in June 2014 (about \$4 billion). We further found the total assets and liabilities reported by all non-US listed Mainland photovoltaic producers (as we report in Figures 28, 33a and other figures later in the paper). We then allocate the total value of equity, debt, short and longterm assets and liabilities to various tradable securities shown in the figure. Insurance estimates come from the estimated premiums paid on the total value of insured assets (including financial assets) which come to about $50 \%$ of total.

Source: authors - based on data from WRDS (2014). 
The maximum achievable market size for trade in Mainland solar companies financial assets and liabilities in the short-term comes to about \$20 billion. Such an estimate assumes Hong Kong financial intermediaries can securitize all assets and liabilities of non-US listed Mainland solar companies. If Hong Kong companies could generate 1\% of the value of these financial assets in commissions, fees, capital gains (from sales) and so forth, the revenue generated from these assets could amount to $\mathbf{\$ 2 0 0}$ million per year. Moreover, by specialising in solar finance, Hong Kong's financial intermediaries can provide cheaper and easier financing than rivals in Beijing, Shanghai and Shenzhen. ${ }^{73}$ Such specialisation could help ensure Hong Kong's financial institutions receive this lucre.

Such computations also tell us something useful about writing the financial law which underpins Hong Kong as an international financial centre. These estimates suggest exactly which types of securities policymakers need to regulate (and which to encourage). In this case, legal changes which develop Hong Kong's debt markets appear as a priority. We also see that the unique profile of solar companies' assets and liabilities makes their securitisation (and the sale of these securities) a profitable and socially useful function. Looking at solar market financial needs provides a much better guide for making financial law in Hong Kong than “structural” approaches like resorting to best practice.

\section{Hong Kong and the geography of solar finance}

Why should Mainland solar companies use Hong Kong-based financial intermediaries instead of those located closer to them? Indeed, Chinese photovoltaic production tends already to centre on areas of Chinese finance. Figure 10 shows major areas of photovoltaic production on the Mainland. As we saw in a previous figure, most of the actual electricity generation occurs in China's western provinces (close areas of high solar irradiation). Yet, production tends to occur close to financial and industrial centres in China's eastern provinces. ${ }^{74}$ The greater Shanghai area clearly represents a cluster - its photovoltaic companies developing around a sustainable source of finance - with assets totalling 33.9 billion RMB (or about $\$ 5.4$ million). The next largest cluster centres on Tianjin - geographically close to Beijing (the banking centre of China). ${ }^{75}$ The third largest centre lies around Shenzhen - a third financial centre. The geographical location of solar companies on the Mainland generally follows the location of finance. ${ }^{76}$

\footnotetext{
${ }^{73}$ Arner et al. (2014) provides an overview of the strengths and weaknesses of China's other major financial centres.

${ }^{74}$ For a more detailed description, see Mark Ng, Economic Impact of the Photovoltaic Industry in China After the Financial Crisis of 2009, 44 CHINESE ECON. 3, 2011.

${ }^{75}$ As we describe in a separate paper, Beijing, Shanghai, Shenzhen and Hong Kong have (to some extent) sought complementary financial services - with Beijing focusing on banking, Shanghai on equities and debt, Shenzhen on initial public offerings and Hong Kong of international shares. See Arner et al. (2014).

${ }^{76}$ We described several theories of economic geography in the previous section. In this case, government policy has played an important role in the sector's development, with plans dictating where certain solar companies locate. For a description of the way Chinese government policies influenced the location of solar companies' activities, see Sufang Zhang and Yongxiu He, Analysis on the development and policy of solar PV power in China, 21 ReNEW. \& SuStAin. EneRgy ReV. 1, 2013. See also Mo-lin Huo and Dan-wei Zhang, Lessons from photovoltaic policies in China for future development, 51 ENER. POL. 1, 2012.
} 


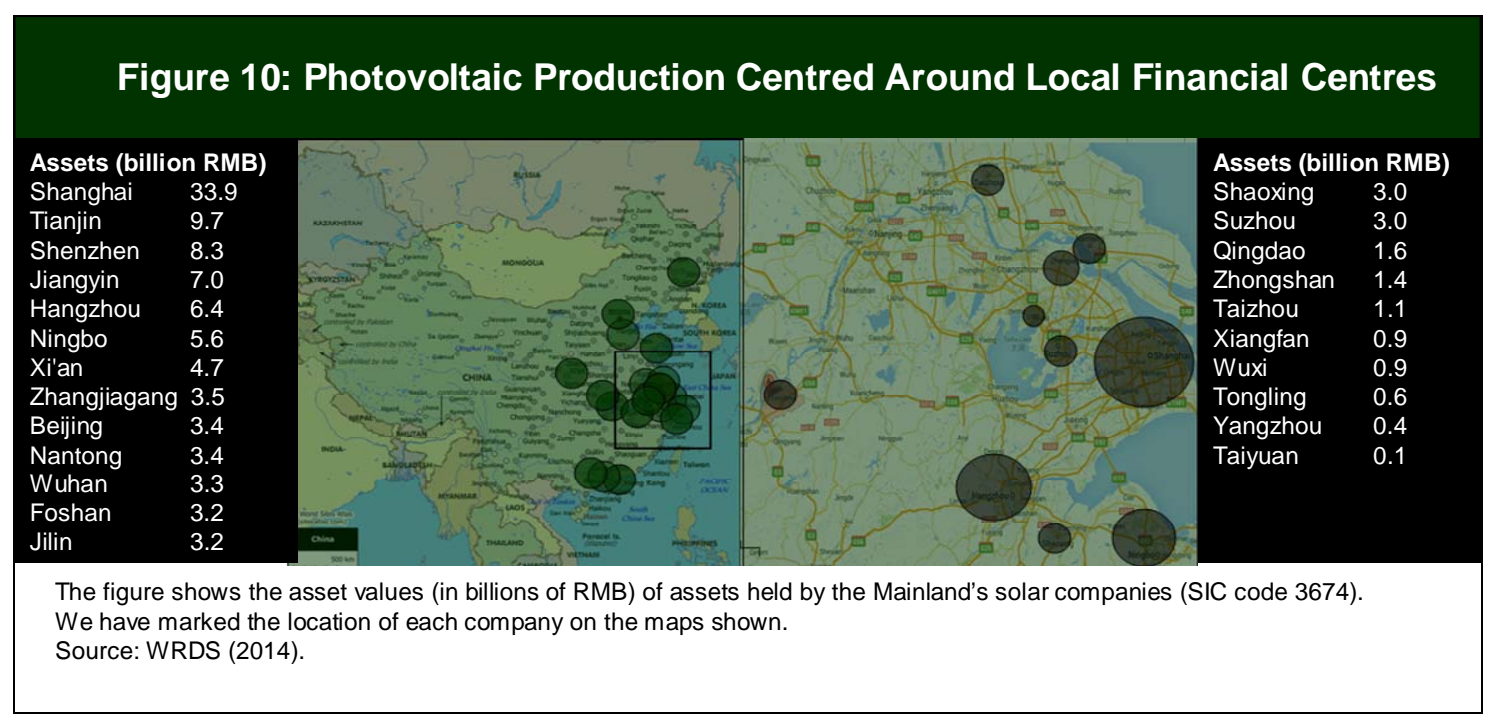

Does the smallness and distance of Hong Kong's own solar panel industry preclude its financial institutions from playing a pivotal role in financing the Mainland's solar industry? Not necessarily. Much research from the US suggests that companies looking for capital do not necessarily use the financial institutions in their same city or geographical area. Chen et al. for example, find a higher success rate for private equity investments in companies located outside the venture capitalist's own city. ${ }^{77}$ In $14.5 \%$ of the cases, these financiers make investments in companies which eventually result in an initial public offering located outside the city where the venture capitalist's headquarters lies. Initial public offerings from investments made outside of cities where venture capitalists have offices weigh in at about $17 \%$ of the total. Moreover, investor networks tend to form "barbell" patterns, with a clustering of investors who make geographically distant investments. ${ }^{78}$ If Hong Kong and China follow this pattern, we can expect a clustering of Hong Kong-based solar energy investment firms.

The literature suggests that such "barbell” pattern may develop in the geography of solar investment between Hong Kong (as a financial centre) and Shanghai (as a solar company centre) for several reasons. Figure 11 provides a summary of some of the literature pointing to the development of such a pattern. Financial firms -- like all firms -- benefit from knowledge spillovers and reduced transactions costs as they locate together. ${ }^{79}$ However, authors like Tykvova and Schertler (2010) might argue that a solar energy

\footnotetext{
${ }^{77}$ See Henry Chen, Paul Gompers, Anna Kovner, and Josh Lerner, Buy Local? The Geography of Successful and Unsuccessful Venture Capital Expansion, HBS WP 09-143, 2009, available online.

${ }^{78}$ For an early view of this pattern, see Olav Sorenson and Toby Stuart, Syndication Networks and the Spatial Distribution of Venture Capital Investments, 106 AMER. J. OF SOC. 6, 2001.

${ }^{79}$ Chen et al. (2009), which we have cited above, provides one of most relevant studies for our purposes. For other evidence focusing on London, see Gary Cook, Naresh R. Pandit, Jonathan Beaverstock, Peter Taylor, Kathy Pain, The Clustering of Financial Services in London, ERSA WP 04P49, 2004, available online.
} 
financial cluster can not exist in isolation. ${ }^{80}$ They find evidence of such a "barbell" effect -- with a more geographical proximate financial cluster developing and interacting with a distant one. As we show later, Hong Kong can clearly serve as the "local” solar financing cluster interacting with the large Mainland solar company investment clusters in New York and Chicago. Sorenson and Stuart provide another study showing that financial cluster development occurs with some geographical distance from the sunrise industries they fund. ${ }^{81}$ Indeed, their "bridging" role in bringing new ideas, technologies and money to a sunrise industry cluster, necessitates a fair amount of distance. Hong Kong provides the advantage of being not too far, but not too close, to Mainland solar panel producers and other value chain members.

\section{Figure 11: Hong Kong Should (in theory) provide a deep financial centre for Mainland solar company finance}

Factor

clustering effects

Chen et al. (2009)

complementarities

between local

investors and

internationals

Tykvova and

Schertler (2011)

intermediate

distance effects

Sorenson and

Stuart (2001)

"portfolio effects"

Devigne et al

(2013)

positive and

negative rivalry

effects

Bengtsson and

Ravid (2009)

culture and

institutions effect

Dai et al. (2012)

winner takes most

effects

Wojcik (2010)

\section{Description (as modified to reflect solar investment)}

Knowledge spillovers occur as firms with competencies in solar finance cluster.

Location clearly affects financiers' sizes and/or number of deals done. Suggests that Hong Kong solar finance companies need to amass both size (scale and diversity) in order to compete effectively with local Shanghai-based investors.

Local investors will look for international investors with greater experience and deeper pockets. Local investors will bring local knowledge and proximity. Suggests complementary between Shanghai and Shenzhen local investors and Hong Kong financial institutions as "foreign" partners. Or Hong Kong could serve as the "local” financial centre - dealing with large Mainland solar investors in the EU and US.

Probability of investment declines with distance. Beyond a certain point (around 10 miles) the marginal decrease in probability is close to zero. Such a finding means that investees happy to take money from a partner 100 miles as much as one 1000 miles away. Implies that Mainland solar companies may see little difference between Hong Kong-based and Nebraska-based investors.

Companies in a venture capitalist's portfolio may exhibit complementarities over time. Solar panel investors with already existing investments in integrated circuits, electricity and other sectors would like build up investing competencies hard to emulate on the Mainland.

Venture capitalists balance positive and negative rivalry effects. On the one hand, intense rivalry encourages financiers to focus more intently on solar companies' needs. On the other hand, intense rivalry among investors - and large amounts of funding opportunities -- encourages the development of investee unfriendly contract terms.

More investment occurs with similarities between investors' and investees' culture and institutions. Implies Hong Kong preferred because of similar culture. Yet, Hong Kong's institutions more similar to New York and London -- making uncertain as to whether a "bonding" or "bridging" effect exists.

Securities centres tend to displace banking and insurance centre concentration.

Larger securities centres tend to displace smaller centres. Suggests that Hong Kong needs to develop solar finance competencies quickly to compete effectively against Shanghai and Shenzhen.

\footnotetext{
${ }^{80}$ See Tereza Tykvova and Andrei Schertler, Geographical and institutional distances in venture capital deals: How syndication and experience drive internationalization patterns, ZEW DP 11-022, 2011, available online.

${ }^{81}$ See Olav Sorenson and Toby Stuart, Syndication Networks and the Spatial Distribution of Venture Capital Investments, 106 Amer. J. of Soc. 6, 2001.
} 
The figure shows statistically significant effects (at the 95\% level or "better") from a range of studies analysing the geography of investment. We translate their findings from other industries in other countries (usually the US) to the Hong Kong context into a solar industry context. As usual, readers should interpret such comparisons cautiously, as effects observed in other countries and sectors may not apply to Hong Kong.

Other effects militate against Shanghai or other financial centre serving the Mainland's burgeoning solar industry. One of these effects includes the development of "financing finickiness" among financiers located too close to the sunrise industry. Using Silicon Valley as an example, Bengtsson and Ravid find a "California Effect" which discourages sunrise industries there from obtaining funding locally. ${ }^{82}$ If a similar "Hong Kong Effect" operates like in California, we can expect Hong Kong to be the preferred location of solar finance. Indeed, again if the US experience serves as any guide, Hong Kong companies specialising in financing the Mainland's solar companies might develop a competitive advantage due to their already existing portfolios. ${ }^{83}$ From this perspective, Hong Kong companies already fund Mainland science, technology and other companies. Such preexisting holdings can complement new investments in solar -- increasing returns across the portfolio. Most of these studies imply that Hong Kong needs to race to develop a size and scale needed to offer solar investments before Shanghai and Shenzhen do.

Yet, not all the evidence point inextricably toward Hong Kong’s role as a solar financing centre. A number of scholars point to the important role culture and institutions play in the development of a financial centre focused on particular sunrise industries ${ }^{84}$ Hong Kong shares a similar culture to the Mainland's - and increasingly institutions which "harmonize" with Mainland institutions. ${ }^{85}$ Such an explanation however, ignores the complementary nature of Hong Kong's institutions. As we explain later in the paper, Hong Kong may represent an ideal solar financing centre because of differences in its legal and other institutions with the Mainland. Moreover, Hong Kong may lose out if Shanghai and Shenzhen if its lawmakers do not develop its securitisation markets. Wojcik has noticed the trend that securities markets tend to push out insurance and banking markets. ${ }^{86}$ As securitisation develops, companies and investors move their banking and insurance business to shadow banks (which provide the same services through securitised lending and insurance). Hong Kong has quickly lost its regional role as a securities centre. ${ }^{87}$ Thus, securitisation represents Hong Kong's best bet to grow

\footnotetext{
${ }^{82}$ See Ola Bengtsson and S. Abraham Ravid, The Geography of Venture Capital Contracts, 2009, available online.

${ }^{83}$ See David Devigne, Tom Vanacker, Sophie Manigart, and Ine Paeleman, The role of domestic and crossborder venture capital investors in the growth of portfolio companies, 40 SMALL BUS. ECON. 3, 2013.

${ }^{84}$ See Na Dai, Hoje Job and Sul Kassicieh, Cross-border venture capital investments in Asia: Selection and exit performance, 27 J. OF Bus. VentuRING 6, 2012.

${ }^{85}$ Hong Kong administrators have already begun the process of "harmonising" (to take a word from the EU context) Hong Kong laws and institutions with those in the Mainland. Such harmonisatiion has not been without controversy. See Simon Denyer, Beijing reminds Hong Kong residents that it remains 'the real boss', WASH. POST JUNE 11, 2014, available online.

${ }^{86}$ See Dariusz Wojcik, Securitization and its footprint: the rise of the US securities industry centres 1998 2007, J. OF ECON. GEO., 2011.

${ }^{87}$ Arner et al. (2014) documents these trends in detail.
} 


\section{a scale of solar company finance needed to solidify its position as an international financial centre.}

The geographical profile of investment in the larger Chinese photovoltaic companies suggests that Hong Kong has not built up significant investment competencies in this sector. ${ }^{88}$ Figure 12 shows the location and holdings of major mutual fund and institutional investors in the New York-listed Jinko Solar (a Shanghai-based photovoltaic company) - to take one example which represents the broader universe of Mainland solar companies. ${ }^{89}$ We show the number of shares held by mutual funds and institutions rather than brokers and custodians. ${ }^{90}$ Of the $13 \%$ of total company shareholders who report their holdings publicly, Hong Kong-based investors hold a relatively large proportion of the companies assets (about 12\%). ${ }^{91}$ However, institutional investors from other cities hold more than $75 \%$ of these shares. Hong Kong companies' relatively meagre holding represents both a benefit and cost to Hong Kong as an international financial centre. On the upside, having less Hong Kong-centred investment in Jinko benefits the company -as it draws from range of different holders able to bring new perspectives (and gain diversification in return). On the downside, if Jinko represented such a good investment, why don’t more Hong Kong investors take more and larger stakes? Hong Kong institutions and funds are either unwilling or unable to invest in solar companies like Jinko to the same extent as their foreign rivals. In either case, Hong Kong investors clearly do not serve as a value-adding intermediary for local and foreign Mainland solar company investors.

\footnotetext{
${ }^{88}$ Academics have long known that certain investment centres build-up particular competencies in making sunrise industry investments. Investment usually represents a vector by which companies gain access to new skill sets, markets and risk appetites. For a discussion involving equity investment, see Marco Pagano, Ailsa Roell, and Josef Zechner, The Geography of Equity Listing: Why Do Companies List Abroad? 57 J. OF FIN. 6, 2001. For a venture capital perspective, see Henry Chen, Paul Gompers, Anna Kovner, and Josh Lerner, Buy Local? The Geography of Successful and Unsuccessful Venture Capital Expansion, HBS WP 1420371, 2009.

${ }^{89}$ We provide some data on the most concentrated shareholders in various Mainland solar companies later in this paper. We do not provide full data to keep the paper focused on our main argument. We encourage readers to look up the data for themselves to confirm that this case represents the broader whole.

90 Two pieces of public information exist on a company's shareholders - holdings by professional fund managers and (in Hong Kong) holdings by custodians/broker-dealers. The data in the figure show the sliver of shares held by institutions which must publicly report their holdings. They hold roughly $13 \%$ of all of Jinko’s traded shares.

${ }^{91}$ Central Asset Investments represented the main holder of Jinko’s equity among Hong Kong domiciled funds and institutions at around $12 \%$ of assets.
} 
Figure 12: Why Don't More International Investors Get Exposure to Jinko through Hong Kong?

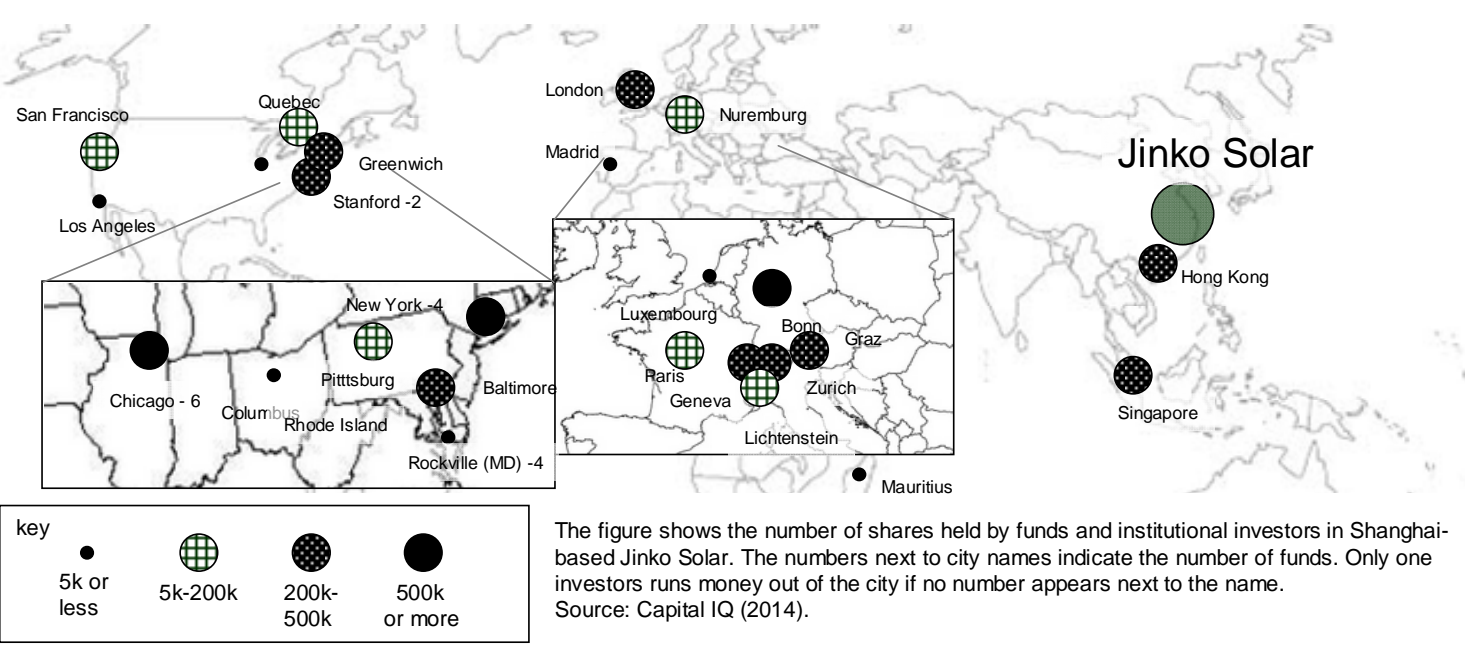

If Hong Kong develops as one end of the "barbell" it will likely serve as a pass-through conduit for real investors located in other jurisdictions. Continuing with our Jinko Solar, we see one example of such a pass-through. Figure 13 shows the nationality of Hong Kong-based custodians holding Jinko Solar's shares. By number of custodians, Hong Kong national broker-dealers represent the majority. However, by shareholding, US and UK firms registered and domiciled in Hong Kong hold the majority of Jinko's shares. Hong Kong serves as a pass-through for other international investors rather than as hub for solar (and other kinds of) local investors.

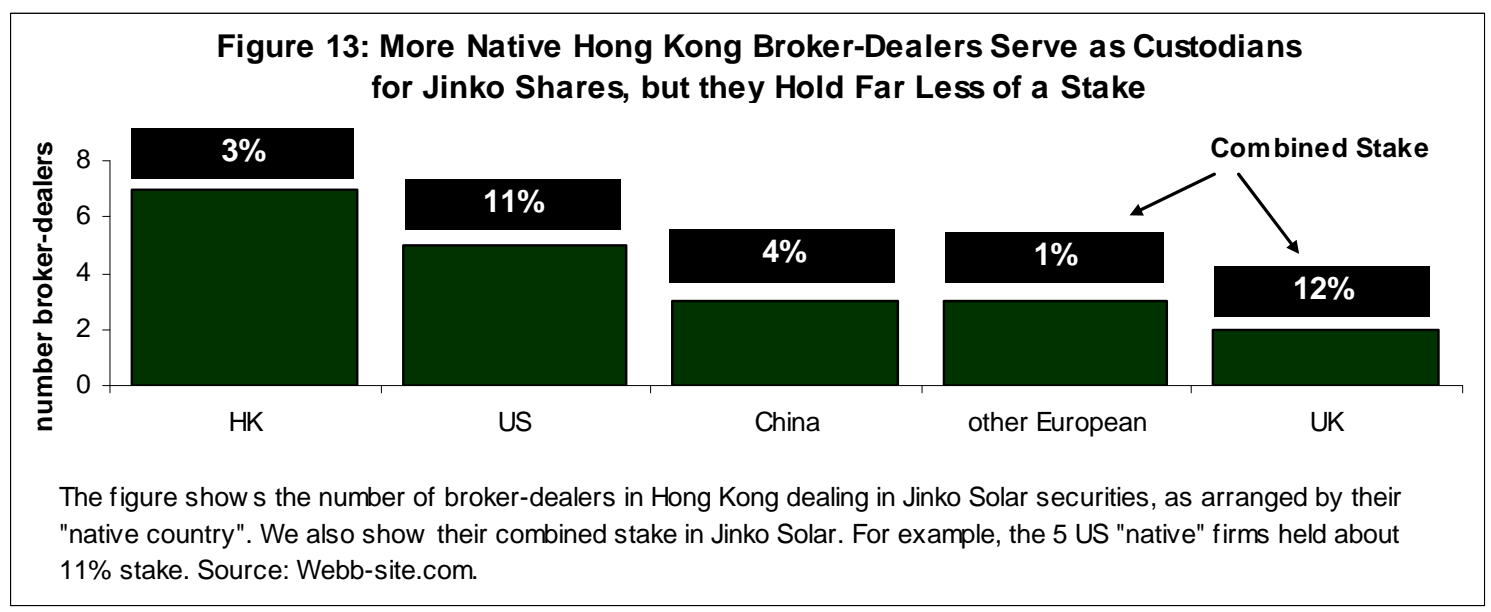




\section{Underlying economics suggests a regionalisation strategy}

Hong Kong's needed leadership as a solar industry finance centre comes into focus when considering the size of future regional solar consumption. Outside of Europe, Chinese markets represented the largest markets for photovoltaics (roughly $35 \%$ in 2012) ${ }^{92}$ Yet, these amounts only represent the tip of the iceberg. Figure 14 shows the potential value of solar energy consumption in the Asian region alone over the next ten years. ${ }^{93}$ In other words, the figure assesses the likely customer spending on photovoltaically-generated electricity over the next 10 years, given a set of assumptions which we chose in order to make economics of the market easier to understand. China represents the largest market at $\$ 470$ billion in potential revenue over the next decade ${ }^{94}$ Russia and India represent the next 2 largest markets with about $\$ 140$ billion in spending between them. Spending in Hong Kong should come to $\$ 430$ billion - a paltry figure in comparison. All together, the value of photovoltaic energy revenues in Asia alone could top half a trillion dollars. Despite claims to the contrary, China's large energy needs mean that the sun won't set on the China solar power industry for quite some time. ${ }^{95}$

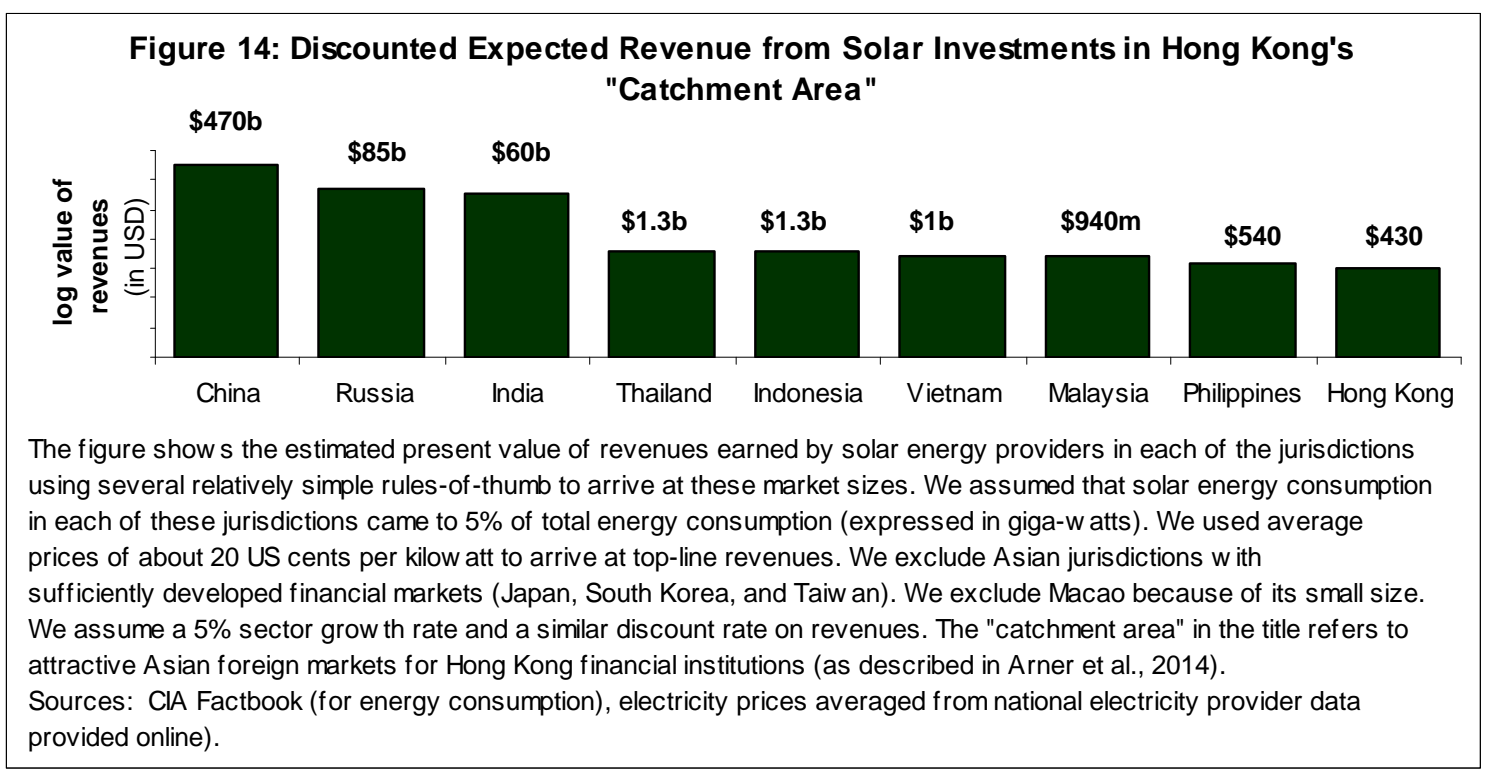

\footnotetext{
${ }^{92}$ See European Photovoltaic Industry Association, Global Market Outlook for Photovoltaics 2013-2017, at Figure 18, available online.

${ }^{93}$ The figure uses rule of thumb values for solar energy consumption and the price per kilowatt in order to keep the paper relatively simple (so it does not turn into a doctoral dissertation sizing solar electricity consumption markets regionally). We refer in the figure to a study of Hong Kong's attractiveness as an international financial centre. See Douglas Arner, David Donald, Say Goo, Richard Hu, Chen Lin, Bryane Michael, Frank Song, Wilson Tong, Chenggang Xu, Dariusz Wojcik, and Simon Zhao, Assessing Hong Kong as an International Financial Centre, 2014, available online.

${ }^{94}$ The growth (or marginal) change in these market sizes come to about $\$ 155$ billion by 2018. Other market size estimates confirm our own estimates. For example, see Matthew Feinstein and Chen Liu, Market Size Update 2013: Return to Equilibrium, 2013.

${ }^{95}$ See Knowledge@Wharton, Why Is the Sun Setting on China's Solar Power Industry?, 2013, available online.
} 
Yet, these amounts only represent the beginning. Solar energy represents less than $5 \%$ of most of the world's energy production (and in most Asian countries represents even 2\% or less). ${ }^{96}$ If countries like the Philippines, India, the Philippines and others manage to expand access to electricity beyond current levels (rather than simply replace coal, gas and oil with solar), market sizes could be much bigger. Many countries politicians are already looking for ways to increase their production (and thus consumption) of photovoltaically generated electricity. ${ }^{97}$ Thus, the market for solar power could be much, much bigger if financial institutions in a place like Hong Kong could figure out ways of providing flexible and low-cost finance to solar technology producers and users. Figure 15 shows electricity usage across the Asia region. As household incomes increase, the price of solar electricity declines and taxes rise on tax carbonemitting electricity production methods, the markets shown in the figure will become more profitable. However, both consumers and producers will need ways of financing such growth. ${ }^{98}$ If Hong Kong's financial institutions can help lower the costs of electricity and provide finance which makes access to electricity more wide-spread, Hong Kong's role as an international financial centre can only increase.

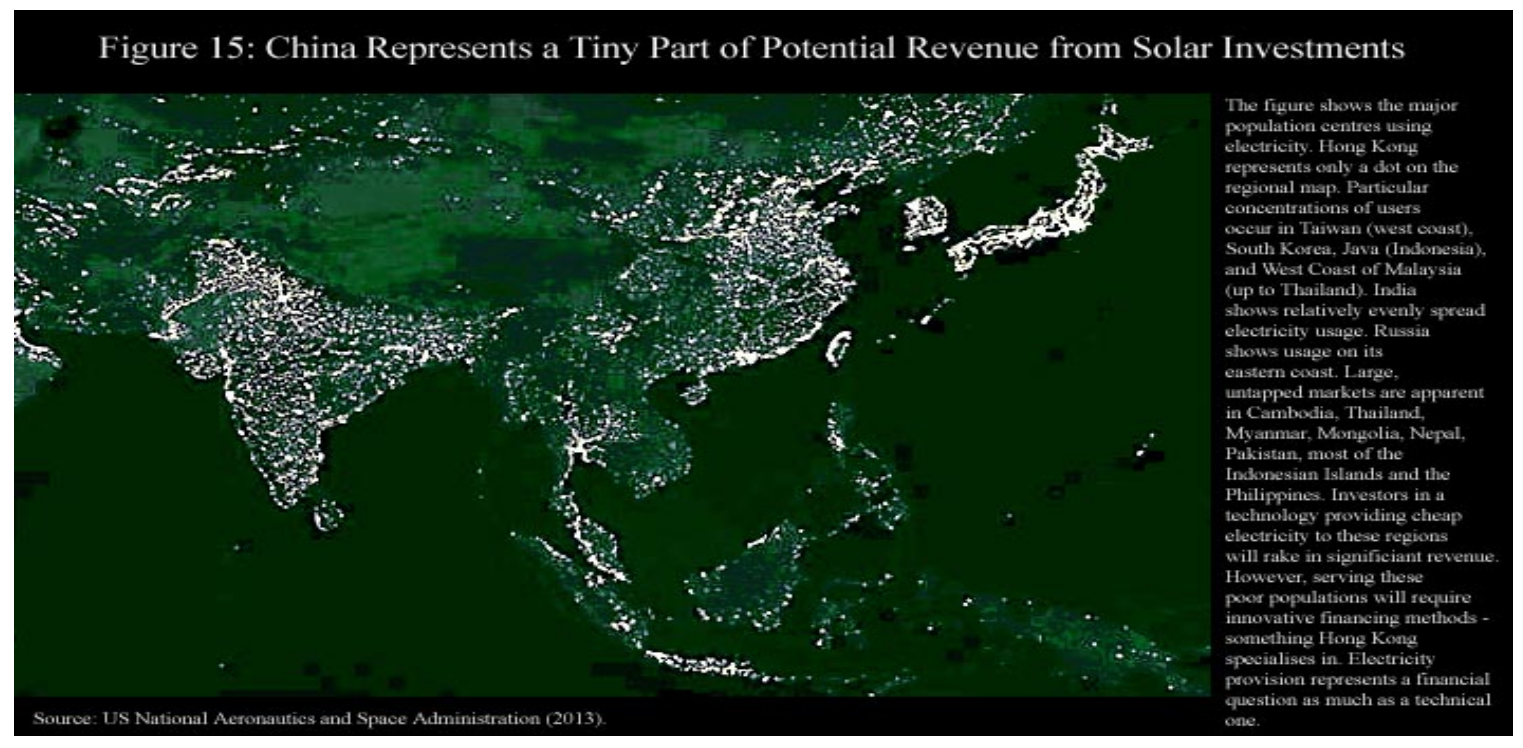

\footnotetext{
${ }^{96}$ See REN21, Renewables 2014: Global Status Report, 2014, at Figure 14, available online.

${ }^{97}$ To that end, the IEA has produced a roadmap to help countries - like those we show on the map - to expand their use of solar energy. See IEA, Technology Roadmap: Solar photovoltaic energy, 2012, available online. Many analysts assume that solar energy would replace electricity generated from coal, oil and other sources. Yet, according to the latest data available, roughly $70 \%$ of the Philippines' population has access to electricity and 75\% of India's has access. As such, the market for solar-generated electricity could expand by serving consumers without access to electricity of any kind.

${ }^{98}$ For more on the way that financing methods affects both supply and demand for electricity in developing countries, see Mahirah Kamaludin, Electricity Consumption In Developing Countries, 2 AsIAN J. OF SOC. SCI. \& HUMANITIES 2, 2013.
} 
Once solar energy costs reach parity with other forms of electricity, solar could provide far more than 5\% of the region's (or world's) energy needs. Current estimates place such cost parity at the end of the decade. ${ }^{99}$ At present, solar power electricity in China is 3 times more expensive than the cheapest alternative (hydropower at 4.21 cents per kilowatt hour) and up to two times more expensive than the next most expensive form of electricity generation (biomass at 11.90 cents per kilowatt hour). ${ }^{100}$ Affirming Reichelstein and co-authors' analysis, Zhao and co-authors find that if cost decreases continue on their current trajectory, solar power should reach parity with the cheapest by the end of the decade. ${ }^{101}$ Most authors agree that solar energy costs will come down to represent the cheapest forms of electricity generation - making photovoltaics the preferred method of electricity generation. Once photovoltaic reach cost parity with other forms of electricity generation, the total market potential over the decade could easily reach \$1-\$2 trillion. If Hong Kong financial institutions provide even $10 \%$ of that finance, such finance would increase the size of Hong Kong's portfolio assets under management by $30 \%$-- but still not even getting Hong Kong close to the league of Japan or Germany as an international financial centre. ${ }^{102}$

Hong Kong financial institutions can also play a role in helping Mainland solar companies regionalise. A number of commentators have pointed to Chinese companies' setting up production facilities in other Asian countries, as labour costs increase on the Mainland. ${ }^{103}$ Figure 16 shows the factors driving such regionalisation - by showing the various components of China's photovoltaic cost advantage vis-à-vis US producers. ${ }^{104}$ Equipment and materials discounts, economies of scale, low labour costs, subsidies and tax holidays represent the various components of China's photovoltaic sector cost advantages. As the Mainland economy heats up, discounts, labour-cost advantages, subsidies and tax holidays will likely disappear. The Mainland's solar companies will thus look for countries providing these advantages - like Vietnam, Myanmar, Indonesia and other low-cost jurisdictions. Interesting the Mainland's cost of finance (both debt and equity) serve to reduce its cost advantages. To the extent Hong Kong's financial institutions can provide cheaper debt and equity finance to Mainland solar companies, such finance would help promote the Mainland's solar competitive advantage.

\footnotetext{
${ }^{99}$ See Stefan Reichelstein and Michael Yorston, The Prospects for Cost Competitive Solar PV Power, 2012, available online.

${ }^{100}$ Zhen-yu Zhao, Shuang-Ying Zhang, Bryan Hubbard, Xue Yao, The emergence of the solar photovoltaic power industry in China, 12 RENEW. \& SUSTAIN. ENER. REV. 1, 2013.

${ }^{101}$ See Id at Figure 6.

${ }^{102}$ Our estimate of \$1-\$2 trillion comes from doubling the net present value of financial transactions tied to financing solar electricity (as shown in Figure 14) and increasing penetration in the financing of electricity markets in the region (Figure 15). Our estimate of portfolio assets under management comes from Figure 2.2a of Arner et al. (2014).

${ }^{103}$ Even as early as the 2000s, academics noticed increasing Chinese outsourcing to Southeast Asian countries. See Stephen Frost, Chinese outward direct investment in Southeast Asia: how big are the flows and what does it mean for the region? 17 PAC. REV. 3, 2004.

${ }^{104}$ See Alan Goodrich, Douglas Powell, Ted James, Michael Woodhouse, and Tonio Buonassisi, Assessing the drivers of regional trends in solar photovoltaic manufacturing, ENERGY ENVIRON. SCI 6.,2013, available online.
} 


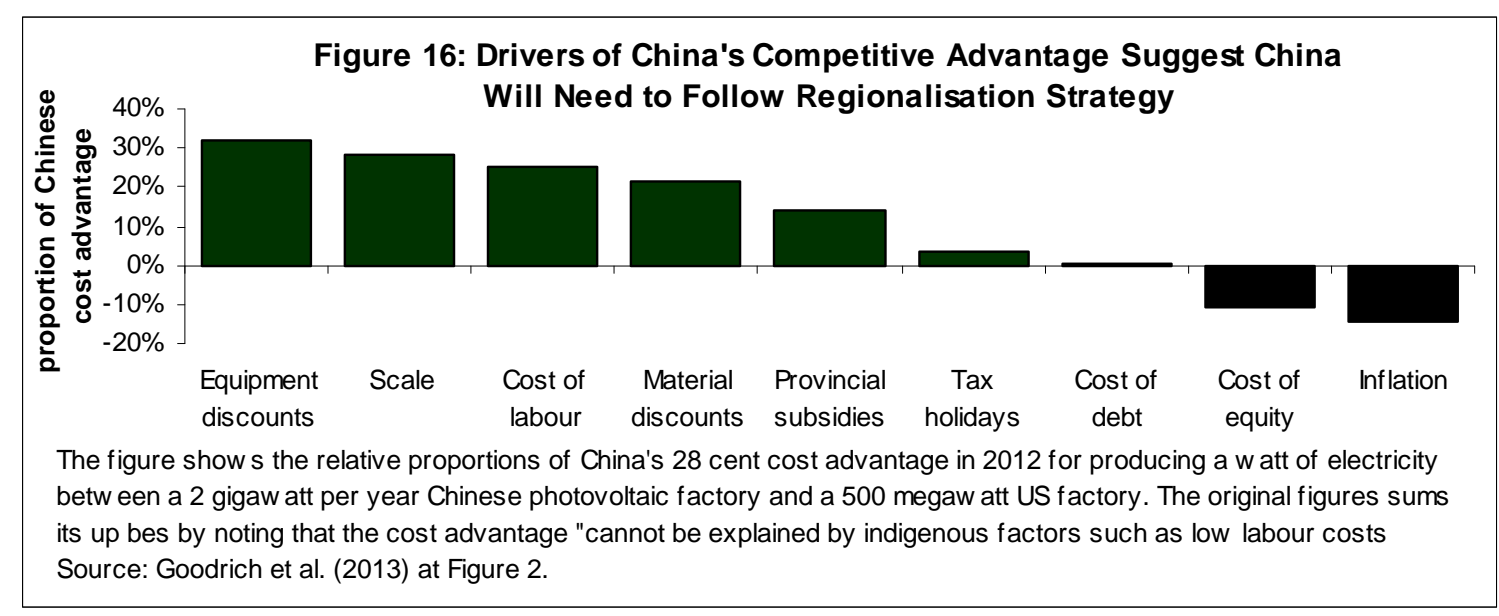

Hong Kong's value as an international financial centre consists of bringing low-cost capital to high photovoltaic-cost jurisdictions. Figure 17 provides a "heat map" for solar energy funding - showing where the cost of capital is cheapest and where the cost of solar electricity is highest. ${ }^{105}$ As we have previously note, an international financial centre represents a technology for bringing low cost capital to fund expensive new tastes and technologies. As shown in the figure, the US and UK represent jurisdictions with some of the lowest costs of capital in the photovoltaic space. Countries like China, India, and Hong Kong itself represent areas where the cost of producing solar energy remains relatively high. The role of international financing institutions (like banks and brokerdealers) consists of helping to provide capital which brings down the cost of such electricity - through economies of scale, financing of research and development, funding licensing agreements and so forth. Given Hong Kong's slightly higher cost of capital, the best strategy consists of intermediating in funding relationships between the US/UK and the Mainland as well as other large electricity users in the region.

\footnotetext{
${ }^{105}$ See Janosch Ondraczek, Nadejda Komendantova and Anthony Patt, WACC the Dog: The Effect of Financing Costs on the Levelized Cost of Solar PV Power Contents, HAMBURG U. SGCRU WP FNU-201, 2013, available online.
} 


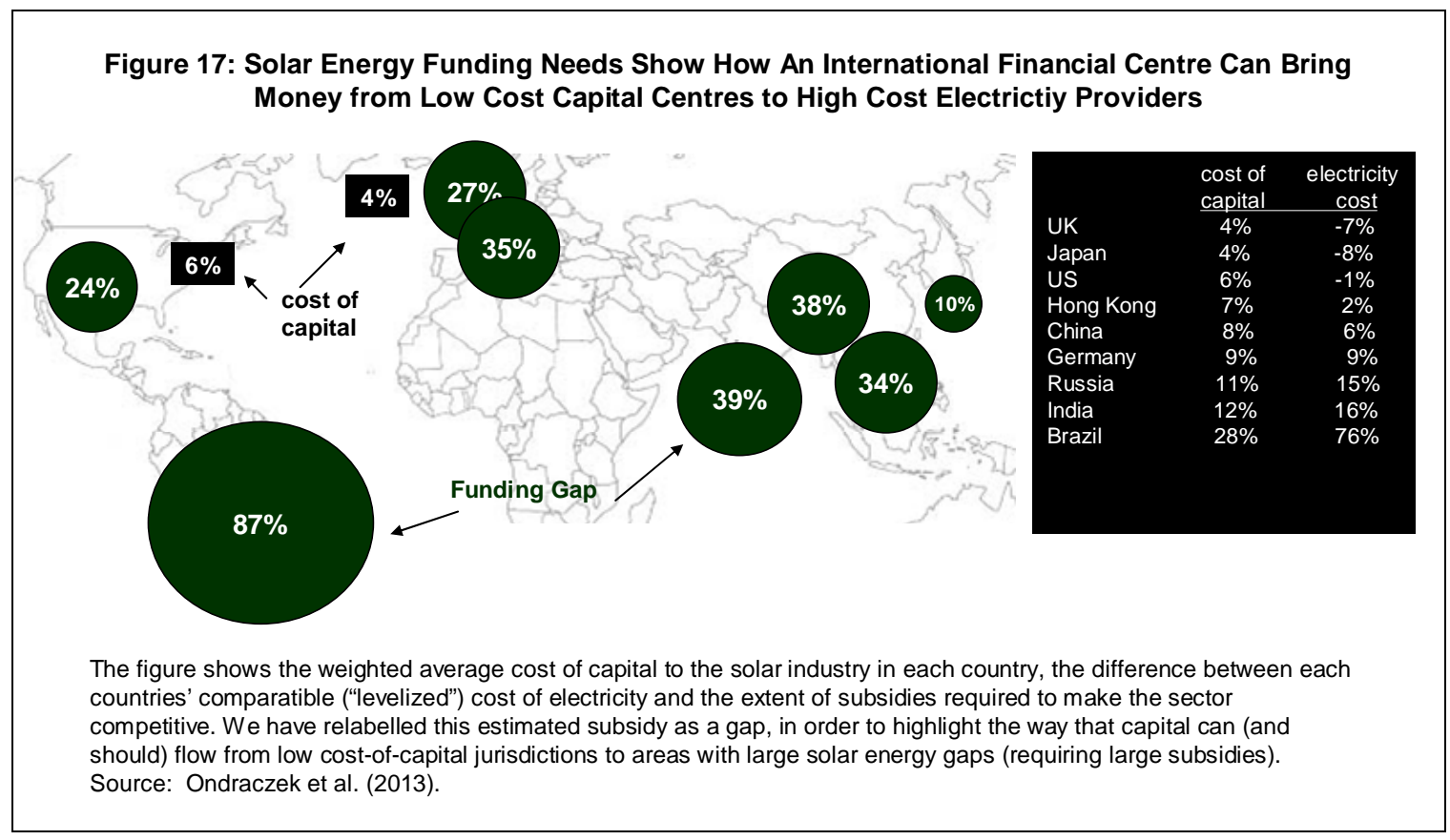

How can Hong Kong's financial institutions intermediate (by putting themselves in the middle of) financing relationships between UK/US financiers and the Mainland's solar companies. As we have shown previously, many Mainland solar producers list in the US - and a number of US funds and institutions buy Mainland shares (listed anywhere) for resale in solar-branded funds. How can Hong Kong financial firms step into funding chains? Hong Kong's financial institutions need to provide financial services which American and British funders can not easily provide. Hong Kong's stock exchange and bonding trading is shallower than the US and UK's. Instead, Hong Kong institutions can help Mainland solar firms "squeeze” more return out of their assets. Securitization probably represents the most important way of squeezing more risk-adjusted returns out of Mainland solar company assets (and liabilities). ${ }^{106}$.

\section{Securitising Mainland Solar Assets through Stocks, Bonds and More Exotic Securities}

\section{Hong Kong attracts less interest from solar equity investors than expected}

Solar equity markets provide for a profile of risks and returns potentially useful for international investors. From a regulatory viewpoint, lawmakers in an international financial centre care about whether regulations help encourage equity prices to move in a way which helps allocate capital to companies efficiently. ${ }^{107}$ They also care about

\footnotetext{
${ }^{106}$ Other services include advising solar companies (like private equity firms do), providing insurance and other services not easily available on the Mainland. We focus on securitisation to keep our paper focused on a critical area of finance - not only for solar firms themselves, but also for Hong Kong's development as an international financial centre.

${ }^{107}$ For these criteria and the extent to which various countries' stock markets fit into these criteria, see Ana Carvajal and Jennifer Elliott, Strengths and Weaknesses in Securities Market Regulation: A Global Analysis, IMF WP 7259, 2007, available online.
} 
whether such prices contain information about companies' risks as well as potential returns. Moreover, they want regulation which promotes the depth needed to ensure valuations do not excessively reflect investors' income rather than companies' fundamental value. ${ }^{108}$ A cursory glance at solar companies' equities prices shows no obvious signs that listing in Hong Kong reduces a solar companies’ prospects for attracting investors (or investors' prospects of profiting from their investments). ${ }^{109}$

A prima facia view of Hong Kong-listed Mainland solar companies' equity prices fail to uncover obvious problems in the way the Hong Kong stock exchange likely allocates capital to these companies. ${ }^{110}$ Figure 18 in particular provides an overview of the way solar companies' equities prices in recent years have reflected the underlying fundamentals driving the supply and demand for solar company shares (across countries and across the industry). From around 2012, the value of the NYSE Bloomberg Global Solar Energy Index (reflecting photovoltaic companies' share prices) has risen with the value of equity markets in general. Yet, even during a time of rapid equity price inflation, the global solar index has fallen. Such a fall reflected sectoral over-capacity and supply as well as supply-side factors. ${ }^{111}$ Since the second quarter of 2013, the index has risen significantly - potentially providing gains to investors who bought in there (but still not recovering losses for those buying at the beginning of 2011).

\footnotetext{
${ }^{108}$ Few economists have recently conducted rigorous econometric analysis of the factors that drive Hong Kong equity returns. For two examples, which clearly show that factors other than companies' fundamental value, drive equity returns, see Michael McKenzie \& Olan Henry, The Determinants of Short Selling in the Hong Kong Equities Market, U. Melbourne Econ. Dept. RP 1001, 2007, available online. See also Alexandros Garefalakis, Augustinos Dimitras, Dimitris Koemtzopoulos and Konstantinos Spinthiropoulos, Determinant Factors of Hong Kong Stock Market, 62 INT’L RES. J. OF FIN. \& ECON. 1, 2011, available online.

${ }^{109}$ Our study broadly supports other findings about the quality of Hong Kong's financial markets. See Fabian Lipinsky and Li Lian Ong, Asia's Stock Markets: Are There Crouching Tigers and Hidden Dragons? IMF WP 14/37, available online.

${ }^{110}$ Evidence suggests that investors use London for liquidity purposes and Hong Kong for information purposes. See Sumit Agarwal, Chunlin Liu, Ghon Rhee, Where does price discovery occur for stocks traded in multiple markets? Evidence from Hong Kong and London, 1 J. OF INT'L MON. \& FINANCE 18, 2006

${ }^{111}$ In other words, equity prices broadly reflected investors' changing perceptions of discounted cash flows coming from solar equities. To trace changes in equities prices with changing supply and demand conditions, see IEA, A Snapshot of Global Photovoltaic Market 1992-2012, available online.
} 


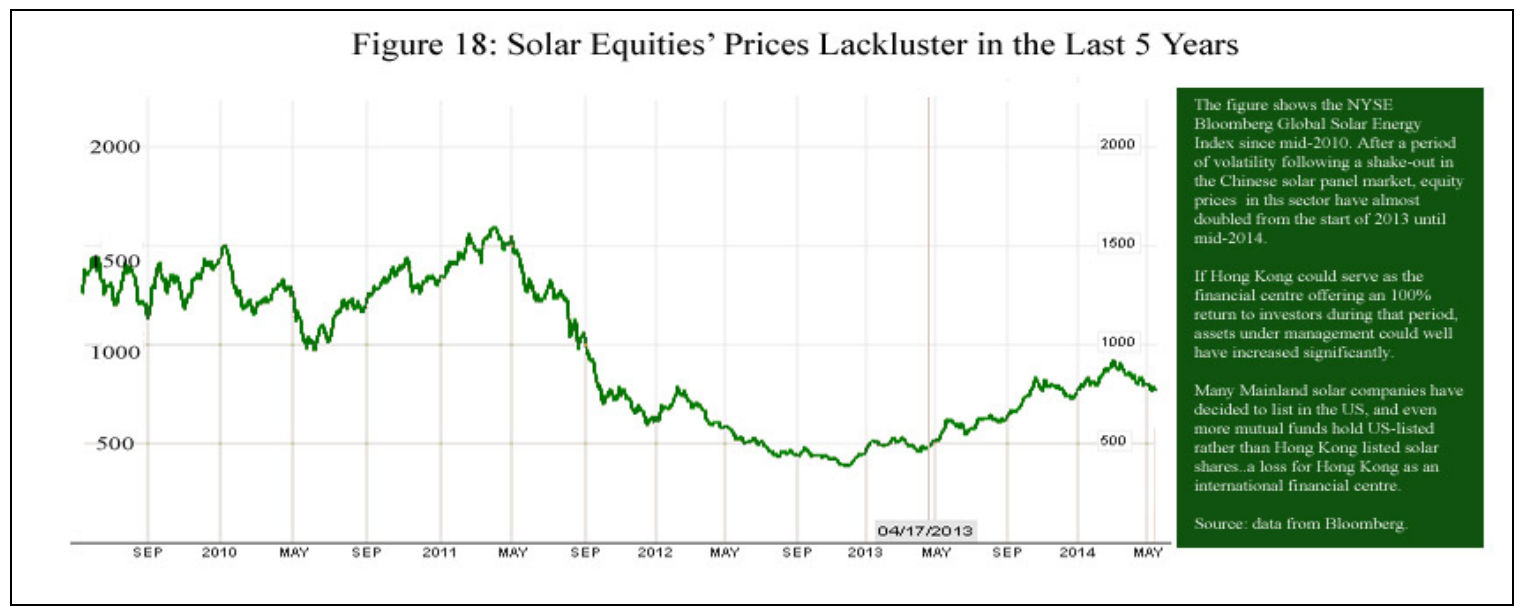

Price changes in Mainland solar shares listed in Hong Kong exhibit no obvious differences from those listed in New York. Figure 19 provides a look at the potential risks, returns and liquidity of trading in several Mainland solar companies' shares. As shown, risk (as represented by these shares' beta) has no obvious correlation across exchanges. Price-to-sales (revenues) ratios also seem higher for Hong Kong listed shares - though the small and non-random nature of this sample almost surely accounts for such differences. ${ }^{112}$ Average volumes traded also seem more influenced by each companies' news rather than factors specific to each exchange. ${ }^{113}$

\section{Figure 19: Nothing Obviously Different In Way Listing in Hong Kong Affect Solar Stocks' Risks and Returns}

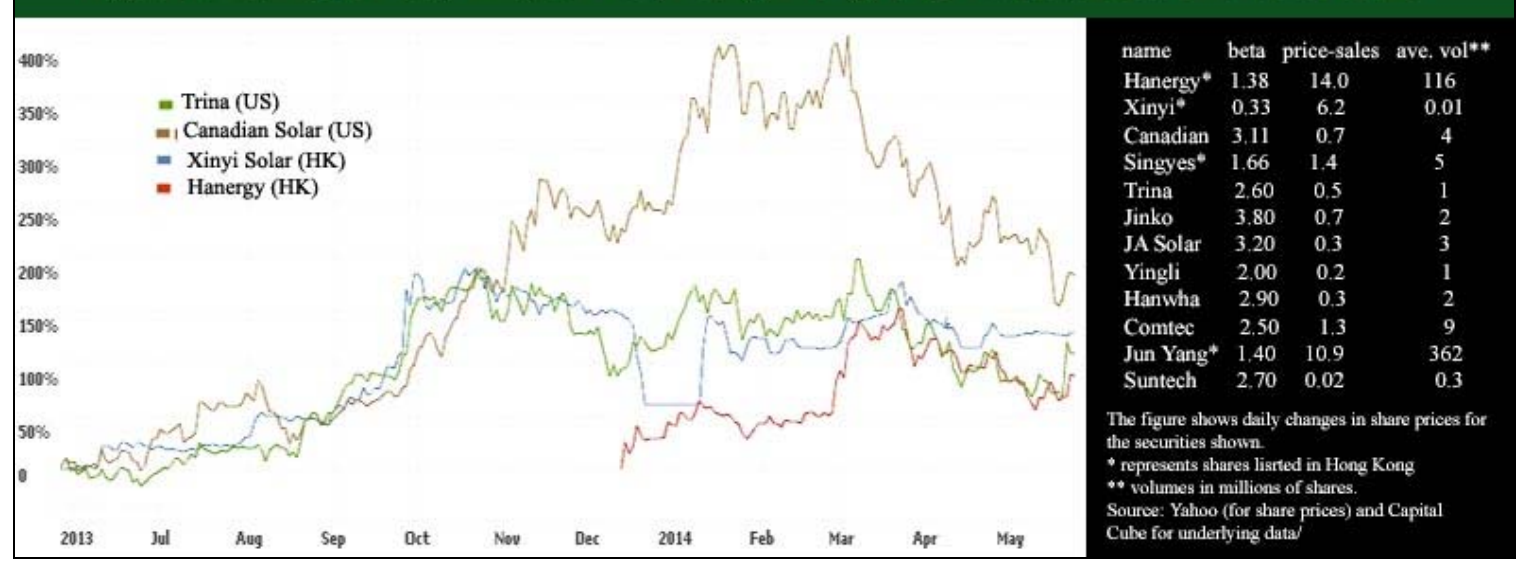

\footnotetext{
${ }^{112}$ Such a finding is consistent with other findings. Interestingly, Li and Chen show that developments on the New York Stock Exchange (NYSE) affect those on Hong Kong's exchange, but the converse is not true - suggesting that new information and innovations occur in New York, making it the "better" exchange. See Shuangfei Li and Shou Chen, The Transmission of Pricing Information of Dually-Listed between Hong Kong and New York Stock Exchange, 2 J. SERV. SCI. \& MANAGE. 1, 2009.

${ }^{113}$ A rigorous approach toward analysing these differences might consist of testing similarities in means between these two groups, using a range of parametric or non-parametric statistics. Given the small sample sizes and the range of variables which likely confound the relationship between listing venue and these equities' risks/returns, we do not include these more complex statistical analyses.
} 
No obvious differences exist in the market capitalisations of Mainland solar shares listed in New York as opposed to Hong Kong. Figure 20 shows the distribution of the roughly $\$ 9$ billion in market capitalisation in the photovoltaic sector across the range of Mainland solar companies. The Hong Kong-listed Hanergy and Xinyi have market capitalisations in excess of the other companies. However, companies like Canadian and Trina have market capitalisations likely to equal or surpass their Hong Kong-listed rivals in the future. ${ }^{114}$ Price-to-earnings ratios vary significantly across companies, appearing slightly higher for US-listed firms than Hong Kong-listed ones. However, no obvious differences suggest that structural issues account for these differences. ${ }^{115}$

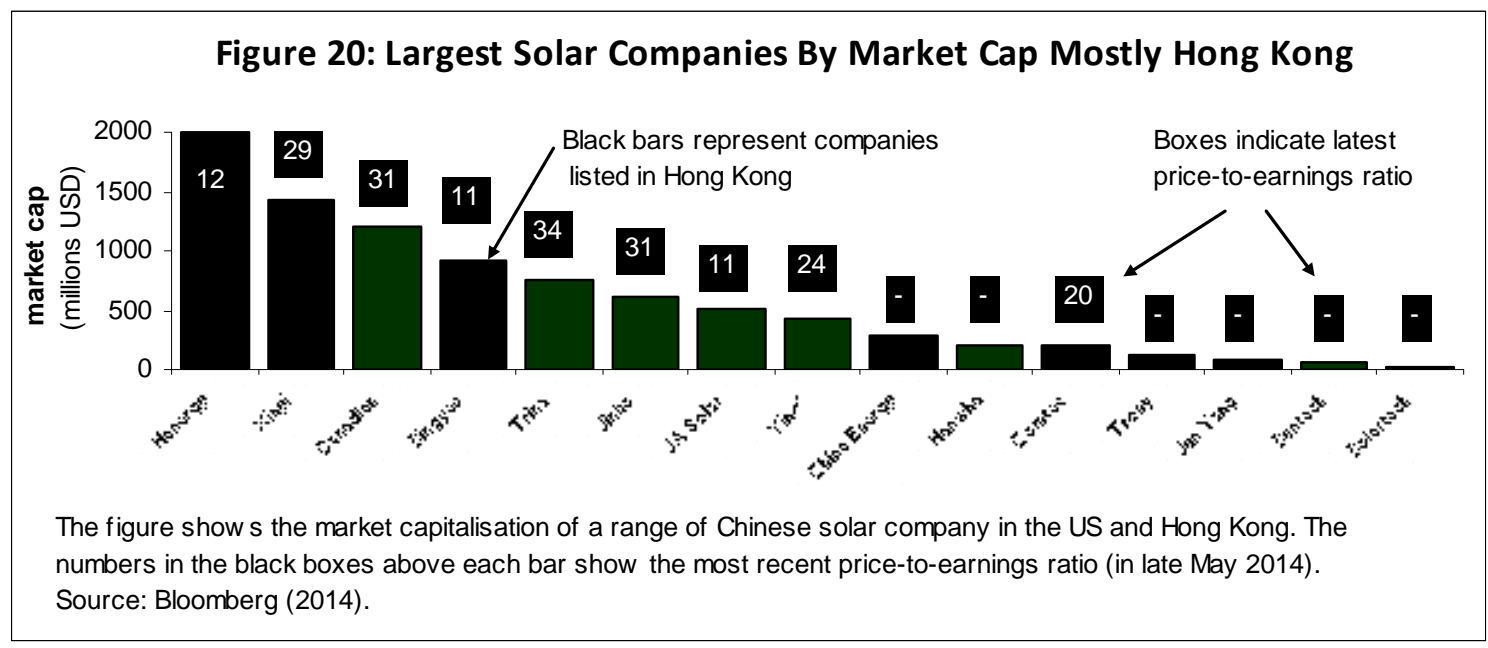

Solar investment "touching” Hong Kong falls far short of what it should - given Hong Kong's geographical and cultural proximity to the Mainland. ${ }^{116}$ Given Hong Kong's close proximity with the Mainland, Hong Kong seems the likely choice of venue for a "foreign" listing aimed at tapping capital outside the Mainland. Yet, as we have seen, only a handful of solar companies list in Hong Kong. Far fewer list on the Shanghai and Shenzhen exchanges. ${ }^{117}$ Those listed on these exchanges have had rather public difficulties. $^{118}$

\footnotetext{
${ }^{114}$ Hong Kong listed companies have attracted about $\$ 1$ billion more in funding than US-listed shares (at about $\$ 5$ billion).

${ }^{115}$ Price-to-earnings ratios reflect companies' potential performance as well as general market sentiment. When these ratios remain too low over the longer term, such levels may signal inefficiencies in the stock exchange's operation. For a discussion in the Mainland context, see Alan Huang and Tony Wirjanto, Is China's P/E Ratio too Low? Examining the Role of Earnings Volatility, 2010, available online.

${ }^{116}$ A number of authors have commented on the trend for international portfolio investors to invest in markets with similar language, culture and history. See Raj Aggarwal, Colm Kearney, and Brian Lucey, Gravity and culture in foreign portfolio investment, 36 J. OF BANK. \& FIN. 2, 2012. See also Selen Guerin, The Role of Geography in Financial and Economic Integration: A Comparative Analysis of Foreign Direct Investment, Trade and Portfolio Investment Flows, 29 WORLD ECON. 2, 2006.

${ }^{117}$ Finding English-language information about sharing trading on the Shanghai and Shenzhen exchanges proves a far more difficult task - given the far fewer English-language intermediaries writing about these solar companies.

${ }^{118}$ Trading for Chaori Solar - listed on the Shenzhen exchange - has recently been suspended. Himin Solar delayed listing plans on the Shanghai Exchange amid bribery allegations. Hareon Solar and EGing
} 
Similarly, Hong Kong-listed Mainland solar companies seem to have few institutional investors at home (in Hong Kong). Figure 21 shows the geographic dispersion of investors in Hanergy - a Mainland solar company listed on the Hong Kong Stock Exchange. Hanergy's largest investors (in terms of number of shares held) reside in New York, Chicago and San Francisco. ${ }^{119}$ Yet, large funds and institutional investors span the globe from Topeka Kansas (Security Investors, LLC) to Nuremburg Germany (CATUS AG Vermögensverwaltung). Investment seems to follows the already established clusters of competence in collective investment creation and marketing in Chicago, Boston, Frankfurt, Luxembourg, Paris and Tokyo; more than any affiliation based on geography or competencies in the solar sector specifically. However, new bases in Fresno, San Francisco and Austin (centres of the US's high tech boom which generated significant investable funds) represent new investment centres. Investment centres locate around places that have seen a technological wave (boom) in the past.

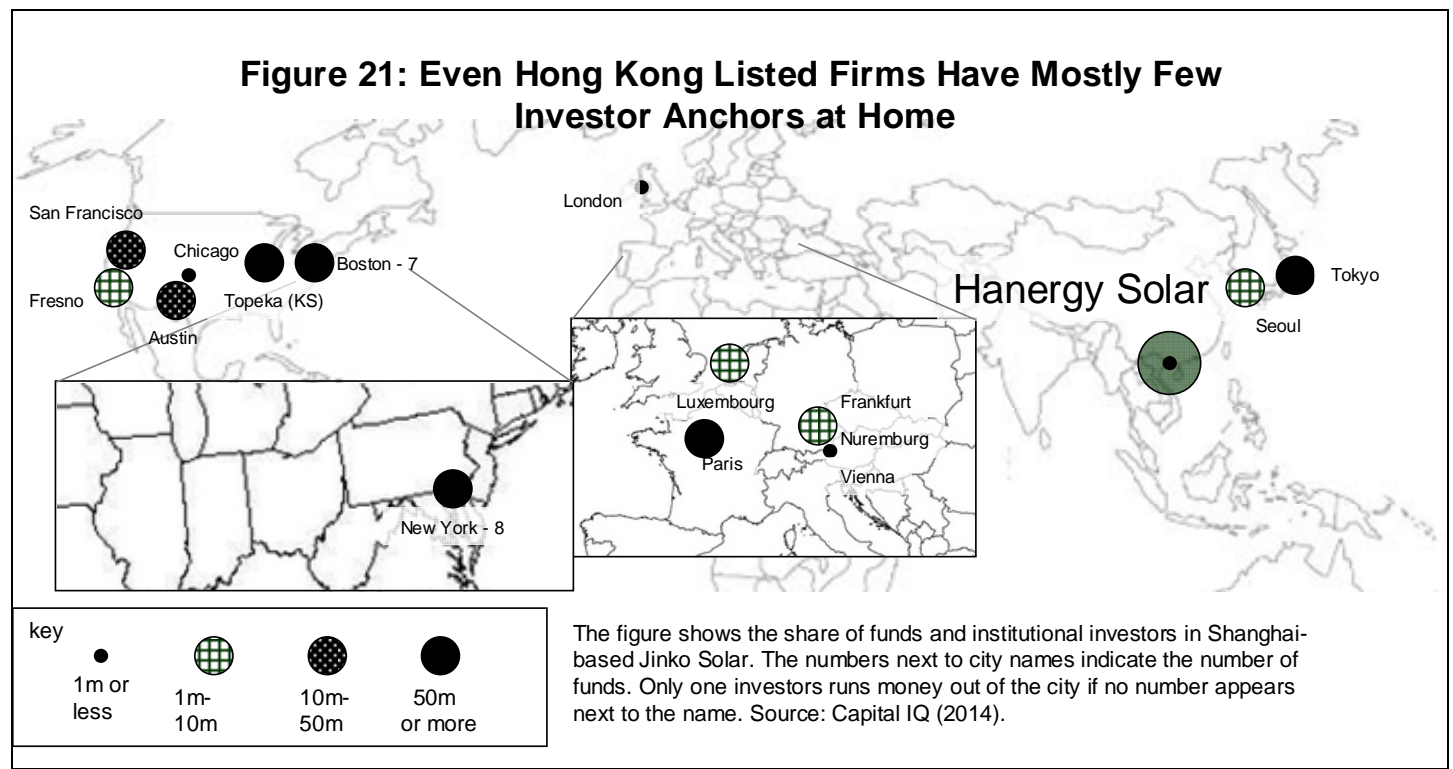

Hong Kong's investors also hold relatively small shares of Mainland solar company investments compared with foreign investors. Figure 22 shows the concentration of holdings in these large Chinese solar manufacturers in funds' and institutions' portfolios. As shown, Hong Kong ranks third - with a higher overall percent of asset holding than New York and London. However, Singapore and Chicago-based investors have taken higher stakes in the major Chinese solar panel producers than Hong Kong-based institutions and funds. ${ }^{120}$ By number of offerings, Chicago remains the undisputed

Photovoltaic (on the Shanghai exchange) as well as Jiawei Photovoltaic (on the Shenzhen exchange) represent companies that have done okay so far.

${ }^{119}$ A specific break-down of these holdings include: Guggenheim Solar (7\%), Guggenheim Funds Investment Advisors (4\%), Guggenheim China Technology ETF (3\%), Market Vectors Solar Energy ETF (7\%), Van Eck Associates Corporation (4\%), iShares Global Clean Energy (4\%).

${ }^{120}$ We do not trace the final (ultimate) ownership interest in these companies. It could be that Hong Kong investors use Chicago-based or Singapore-based funds or institutions to make these investments.

Conversely, institutions and/or funds domiciled in Hong Kong may represent ultimate economic interests in 
champion - with 59 different incorporated funds and institutions offering shares in the Mainland's solar companies. Both Shanghai and Shenzhen represent markets with few solar shares mongered by professional asset managers.

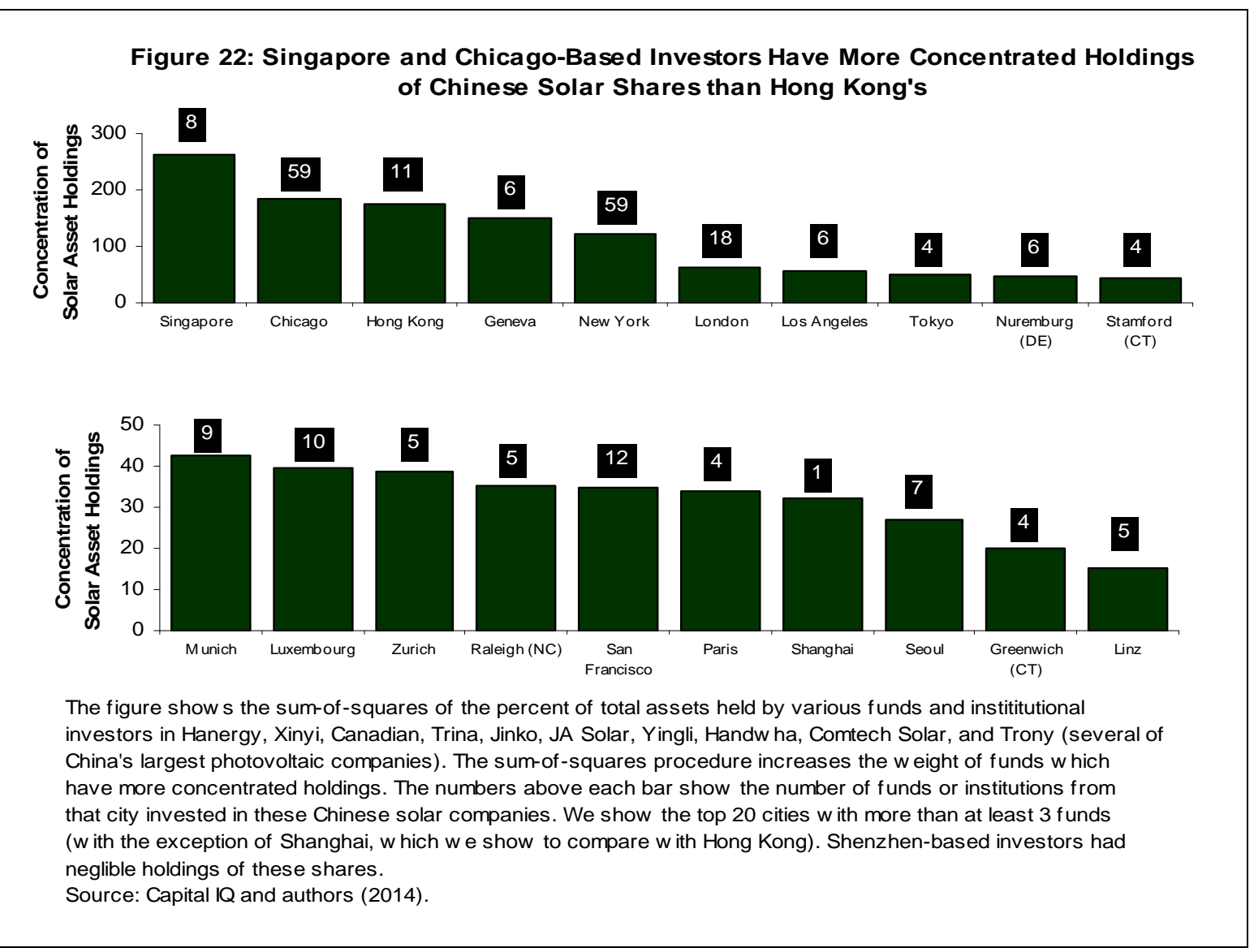

These data point to three things about Hong Kong's financial law. First, Hong Kong markets, while efficient from a technical point of view, generally do not market to foreigners as well as possible. If Hong Kong had superiour methods of marketing Mainland solar companies' shares to US and other investors, they would not need to go through Chicago, San Francisco and New York-based intermediaries. ${ }^{121}$ Something about Hong Kong law must discourage Hong Kong financial intermediaries from developing such marketing competencies...or using them. Second, Hong Kong-based investors do not have sufficient incentives to take larger stakes. Mainland solar companies provide interesting enough risks and returns for Hong Kong-based funds to buy and hold. Yet, we observe relatively low holdings -- and the evidence suggests that some of these shares pass-through Hong Kong on their way abroad. Something about Hong Kong's financial

New York or London. Without more detailed data, we can not guess as to which financial centres’ ultimate investors hold shares in these companies.

${ }^{121}$ US investors would still prefer to buy securities from a US-based broker-dealer. However, if Hong Kong financial institutions had superiour marketing abilities, they could package solar companies and sell them to US retail brokers. In this case, we would observe Hong Kong-based intermediaries ranked among the most concentrated brokers-dealers, instead of US firms. 
law (amid a range of other factors) must be causing Hong Kong investors to prefer other kinds of investments. Third, as we discuss later, something about Hong Kong's financial law clearly discourages Hong Kong intermediaries from packaging both existing securities -- and creating new ones -- for sale at home and abroad. We show later than funds like Market Vectors and Guggenheim have positioned themselves prominently in Mainland solar equity investment relationships with exchange-traded funds, open-ended and close-ended funds. Hong Kong must (and does!) discourage such fund development in the city.

\section{Gains from packaging solar shares into Hong Kong mutual funds}

No Hong Kong financial institution has stepped forward as a specialist investor in the Mainland solar cell sector. As we show shortly, Guggenheim Solar and the Market Vectors Solar Energy represent the two largest funds on record investing in Mainland solar companies. ${ }^{122}$ Figure 23 shows the major Hong Kong based custodians for shares of Hong Kong-listed Mainland solar companies. For example, Standard Chartered served as custodian for about $17 \%$ of Hanergy's shares at the end of May 2014. Of the publicly traded shares, 355 different institutions served as custodians - ranging from Standard Chartered largest share to Futu Securities' smallest. Kingston Securities represented the "go to" broker for Solartech shares - holding shares in street name for $51 \%$ of its shares at the end of May 2014. Yet, roughly 428 different organisations held Solartech's shares. No one intermediary holds a large stake in Hong Kong-listed Mainland solar companies.

\section{Figure 23: No obvious solar investment intermediaries present in Hong Kong markets}

\begin{tabular}{|c|c|c|}
\hline $\begin{array}{l}\text { Solar } \\
\text { Company }\end{array}$ & $\begin{array}{l}\text { Major custodians } \\
\text { (percentages reflect proportion of shareholding) }\end{array}$ & total* \\
\hline Hanergy & $\begin{array}{l}\text { Standard Chartered (17\%), CITIC Securities (15\%), Haitong (11\%), HSBC } \\
(10 \%)\end{array}$ & 355 \\
\hline Solartech & $\begin{array}{l}\text { Kingston Securities (51\%), Bank of China ( } 8 \%) \\
\text { HSBC (22\%), Standard Chartered (12\%), BOCI Securities (11\%), Deutsche }\end{array}$ & 428 \\
\hline Singyes Solar & Bank (6\%) & 205 \\
\hline Trony & BNP Paribas (37\%), ICBC (12\%), HSBC (8\%) & 415 \\
\hline Comtec & JP Morgan (19\%), HSBC (11\%), Guotai Junan (9\%) & 323 \\
\hline Jun Yang & $\begin{array}{l}\text { HSBC (9\%), Standard Chartered (4\%) } \\
\text { HSBC (16\%), Bank of China (15\%), Standard Chartered (10\%), Fordjoy } \\
(8 \%)\end{array}$ & 401 \\
\hline
\end{tabular}

* total custodians refer to the total number of institutions listed.

Source: Webb-Site (2014).

\footnotetext{
${ }^{122}$ We say "on record" as information about shareholders can be notoriously difficult to obtain. US funds disclose far more information about holdings than Hong Kong and other countries' funds. As such, the dominance of these funds may simply reflect reporting (visibility) rather than actual importance. As we discuss throughout this paper though, public transparency and disclosure represents an important way to attract funding to sunrise industries like solar.
} 
The initial data suggest that US-based funds are inserting themselves as key intermediaries in bringing these shares to retail investors. Figure 24 shows the network of broker-dealer holdings of Mainland solar company shares. Hong Kong broker-dealers like HSBC and Standard Chartered hold a relatively larger value of Hong Kong-listed Mainland solar companies' shares than US broker-dealers with specific solar offerings like Blackrock (iShares), Van Eck (Market Vectors), and Guggenheim. Yet, these brokerdealers have positioned themselves in investment networks more centrally (with centrality defined as holdings in the widest number of Mainland solar companies). ${ }^{123}$ They hold relatively large concentrations of these companies' shares and hold larger ranges of solar companies' shares than Hong Kong-based intermediaries. Clearly Guggenheim Solar and Market Vectors Solar ETF represent go-to funds for investors looking to invest in global solar.

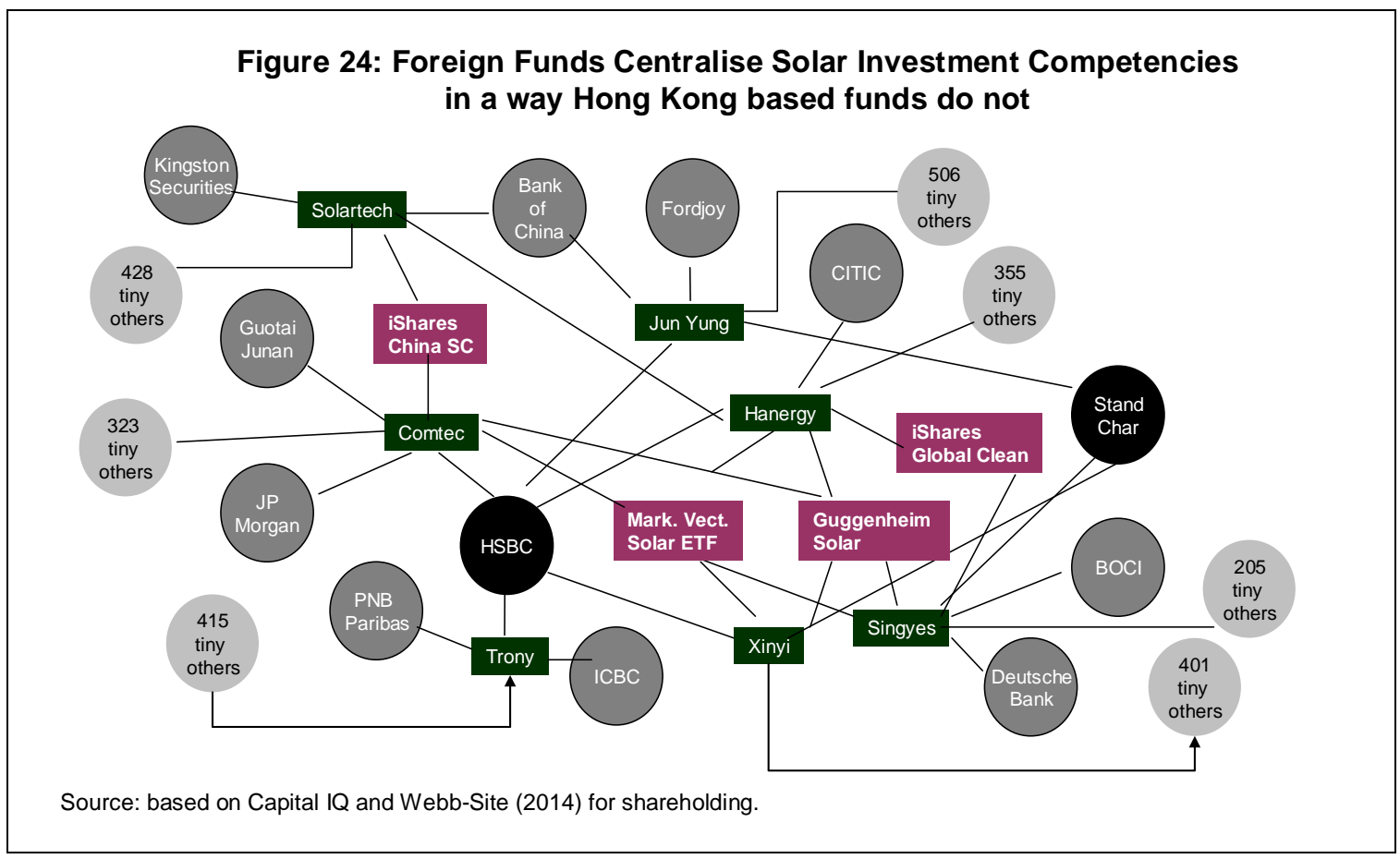

Something about Hong Kong financial law clearly impedes the packaging and distribution of solar investments. Lack of regulations allowing for the establishment of open-ended investment vehicles clearly represents one part of the problem. However, simply following the "structuralist" approach to financial sector development would not

\footnotetext{
${ }^{123}$ We do not provide social network statistics (like centrality, modularity and so forth) in order to keep our discussion simple. Even a non-quantitative look at the investment networks around Mainland solar companies listed in Hong Kong clearly shows the centrality of foreign collective investments, followed by relatively central roles played by HSBC and Standard Chartered as larger holding broker-dealers. Quantitative analysis also confirms our qualitative network diagram more generally, Hong Kong has not become a more central exchange. See Nicola Cetorelli and Stavros Peristiani, Prestigious Stock Exchanges: A Network Analysis of International Financial Centers, 37 J. OF BANK. \& FIN. 5, 2013, available online.
} 
solve the problem. ${ }^{124}$ Namely, introducing laws which make creating mutual funds -- or undertakings for the collective investment in transferable securities (UCITS) in the EU context - would not solve the problem. Local securities firms have incorporated these mutual funds abroad and sold them in Hong Kong for a long time. The problem lies in marketing - as no Hong Kong institution has the incentive or demonstrated the competencies needed to identify foreign investors potentially interested in solar investments - and provide them with such investments at a profit. ${ }^{125}$ A marketing-based contingency view of financial centre development is required.

Intermediation of Hong Kong-based financial institutions custodial and ultimate ownership holdings of Mainland solar company investments could provide investors with cost-effective exposure to these companies. As we showed above, investors used over 700 different Hong Kong-based broker-dealers to purchase shares in the major Mainland solar companies. Each of these broker-dealers had to find out about the companies, make suitability determinations and potentially even find customers (if they took the shares on their own accounts). Each of these 700 had to conduct research on these solar companies and/or provide for third-party research for their clients -- a significant duplication of time and effort. A mutual fund (or other solar intermediary) making these investments could provide better monitoring, buy shares in larger quantities, and provide for the advantages widely noted in the literature. ${ }^{126}$

A Hong Kong-based mutual fund could provide diversification even while keeping current broker-dealers holdings. What if a Hong Kong broker-dealer pooled all existing investments in Mainland solar companies into a solar mutual fund? Figure 25 shows the proportional holdings of such a solar mutual fund (which we call the Bauhinia Solar Fund only to make the idea more concrete). The fund shown in the figure assumes that Hong Kong-based broker-dealers in such a scheme hold the same value in the fund as their percentage overall holdings for individual Mainland solar companies. The figure also assumes their customers want more diversified holdings of Mainland solar companies' equities -- thus accept swapping their current shareholdings for equivalent shares of the Bauhinia Solar Fund. Broker-dealers, like Chief Securities, could offer their customers greater diversification without having to buy individual shares in each Hong Kong listed solar company directly.

\footnotetext{
${ }^{124}$ At the time of this writing, the Government and outside parties have submitted a range of proposals for creating the legal framework allowing for the establishment such open-ended investment vehicles in Hong Kong.

${ }^{125}$ We have used the canonical definition of marketing to reinforce the idea that Hong Kong's weaknesses stem from marketing rather than legal "gaps."

${ }^{126}$ No data exist on the effectiveness of concentrated shareholding specifically in the solar industry. However, a range of findings show that institutional investors and mutual funds add value. For a discussion of the issues, see Massimo Massa, Why so many mutual funds? Mutual funds, market segmentation and financial performance, INSEAD WP, 1998, available online.
} 


\title{
Figure 25: A Bauhinia Solar Fund Could Help Allocate Fragmented Investments in Hong Kong's Solar Companies More Efficiently
}

\author{
Share* Companies \\ $6 \%+\quad$ Chief Securities, Shanghai Commercial Bank, Bank of East Asia, Wing Lung Securities, \\ Masterlink Securities, Fordjoy Securities and Futures, Chiyu Banking Corporation \\ $5 \%-6 \%$ \\ $4 \%-5 \%$ \\ $3 \%-4 \%$ \\ $2 \%-3 \%$ \\ $1 \%-2 \%$ \\ RHB OSK Securities, Guoyuan Securities Brokerage \\ Enlighten Securities \\ Industrial Securities \\ SG Securities \\ Boom.Com, Quam Securities, China Everbright Securities, Merrill Lynch Far East, Ubs \\ Securities, Ping An Of China Securities, Wing Hang Bank, Hsbc, Standard Chartered, Kgi \\ Securities, First Shanghai Securities, Deutsche Bank, Huatai Financial Holdings. \\ $0.5 \%-$ \\ Morgan Stanley, Credit Suisse Securities, Citic Securities Brokerage, Tiger Securities Asset \\ $1 \%$ \\ Management, Hang Seng Securities, HSBC Broking Securities, Grand Investment (Securities), \\ China Merchants Securities, BOCI Securities, Bank of Communications Trustee, Haitong \\ International Securities, Citibank, CCB International Securities. \\ $0.2 \%-$ \\ $0.5 \%$ \\ Hantec Securities, Bank Of China, Cinda International Securities, DBS Bank, Fu Yip \\ Securities and Investment, Shun Heng Securities, South China Securities, FB Securities, ABCI \\ Securities, CSC Securities, Emperor Securities, China Galaxy International Securities, Hang \\ Seng Bank, Fulbright Securities Ltd, Guosen Securities Brokerage, Skyway Securities \\ Investment, Celestial Securities, Tung Tak Securities. \\ $0.1 \%$ and \\ all other 288 brokers and intermediaries \\ less \\ The figure shows the proportional holdings of various Hong Kong broker-dealers in a hypothetical mutual \\ fund which would merge all existing investments in Hong Kong-listed Mainland solar companies. We first \\ add the value of all Hong Kong broker-dealer holdings in Hong Kong-listed Mainland solar companies. We \\ report each broker-dealers' proportional holdings of that aggregate value, given the value and distribution \\ of each broker-dealers' current holdings.
}

If existing shareholding patterns serve as a guide to investors' preferences, the market could support at least 4 solar mutual funds - though two funds could probably serve to match existing preferences for holding Mainland solar assets. Each Hong Kong broker dealers' clients might desire a different mix of Mainland solar companies. Figure 26 shows the proportions of Hong Kong broker-dealers' holdings of various Mainland solar companies. Firms with clients like China Merchant's have most of their holdings in Hanergy. In contrast, Bank of Singapore's clients have invested (on a proportional basis) more heavily in Singyes Solar. BNP Paribas' clients have invested in Trony, while Macquarie's client's in Xinyi. Many of these broker- dealers' clients will want concentrated holdings in just one company. ${ }^{127}$ However, to the extent they want diversification, Hong Kong's broker-dealers can provide such diversification more cheaply through local intermediation. ${ }^{128}$

\footnotetext{
${ }^{127}$ We assume in the figure that each individual client holds a "representative" (proportionate) share of the allocation/distribution of solar companies held by the custodian broker-dealer in the aggregate. For example, if Xinyi Solar represents 25\% of the Wing Hang's total holdings of Mainland solar stocks and Comtec another $25 \%$, then we assume each client would want a $25 \%$ share of their individual portfolio in Xinyi and another $25 \%$ in Comtec. Naturally, many individual clients will want allocations which differ from the aggregate proportions held by the broker-dealer itself.

${ }^{128}$ We stress local because we have talked about geography. Using a US-based mutual fund makes less sense for Hong Kong and Mainland-based investors.
} 


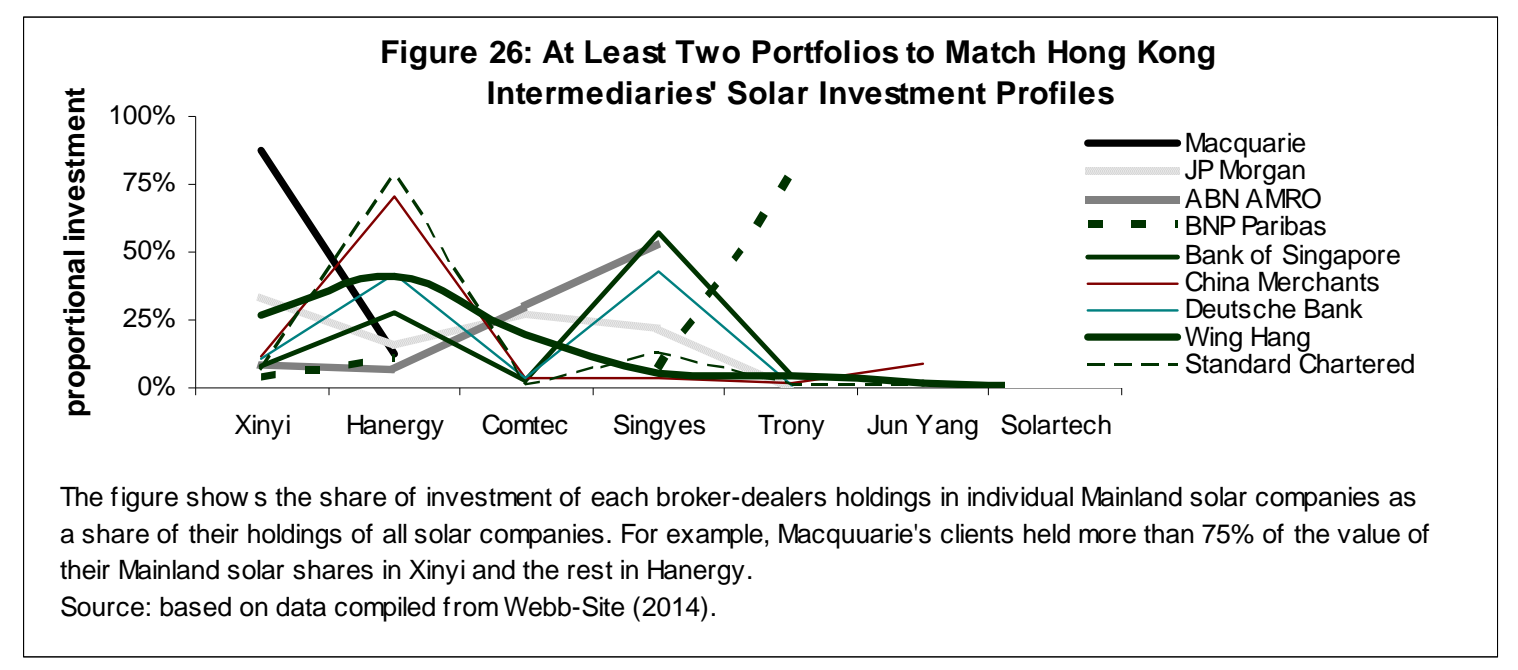

If each custodian's aggregate holdings represents individual investors' portfolio preferences, four solar mutual funds can adequately match existing preferences for holding Mainland solar equities. The first fund would match Standard Chartered and China Merchants holdings -- with its focus on Hanergy. The second fund would replicate Bank of Singapore's and ABN AMRO's holdings -- with their focus on holding higher proportions of Singyes. Most of the large broker-dealers' holdings most closely match the proportion of investment holdings intimated by these two funds. As such, these two funds would probably represent most of collective investments in Hong Kong-listed Mainland solar companies. A third fund could match JP Morgan's relatively even (by comparison) distribution of Mainland solar companies' holdings. The forth fund could spread holdings relatively evenly -- like we observe Wing Hang's and China Merchant's holdings of Comtec, Singyes, Trony, Jun Yang and Solartech. Investors could buy individual shares replicating holdings Macquerie's concentrated holdings in Xinyi and BNP Paribas' holdings of Trony outside of a mutual fund structure. ${ }^{129}$ Clearly, investors could mixand-match these funds to replicate the allocations present in existing broker-dealers' portfolios. For example, if Deutsche Bank bought shares of the mutual fund which focused on the "first fund" and "second fund," such holdings would replicate its existing custodial holdings. Hong Kong financial law should provide better incentives to provide such packages.

\section{Solar companies have enough debt to develop active bond and ABS markets}

Hong Kong could serve as a solar company corporate bond hub if investors had more and better information about the fixed income opportunities present. Solar fixed-income provides sufficient yields to make investors potentially keen on the sector. Figure 27 shows the yields of various solar companies. ${ }^{130}$ With yields above $5 \%$, Mainland solar

\footnotetext{
${ }^{129}$ Mutual funds which invest in only one or two securities would provide few benefits and impose additional and unnecessary costs on investors. As such, not every holding distribution profile shown in the figure represents a viable mix for a separate mutual fund.

${ }^{130}$ The graph does not represent a yield curve for any company or the sector in general. Lack of information forced us to plot several different companies and maturities without controlling for factors like
} 
companies' corporate debt could provide an attractive option for both institutional and retail investors. Some of this yield reflects a risk premium - both around the solar industry in general and investing in Chinese-based manufacturers. Yet, yields drive demand for investments. Clearly a financial centre like Hong Kong able to offer large quantities of high-yield solar assets would attract significant amounts of portfolio assets.

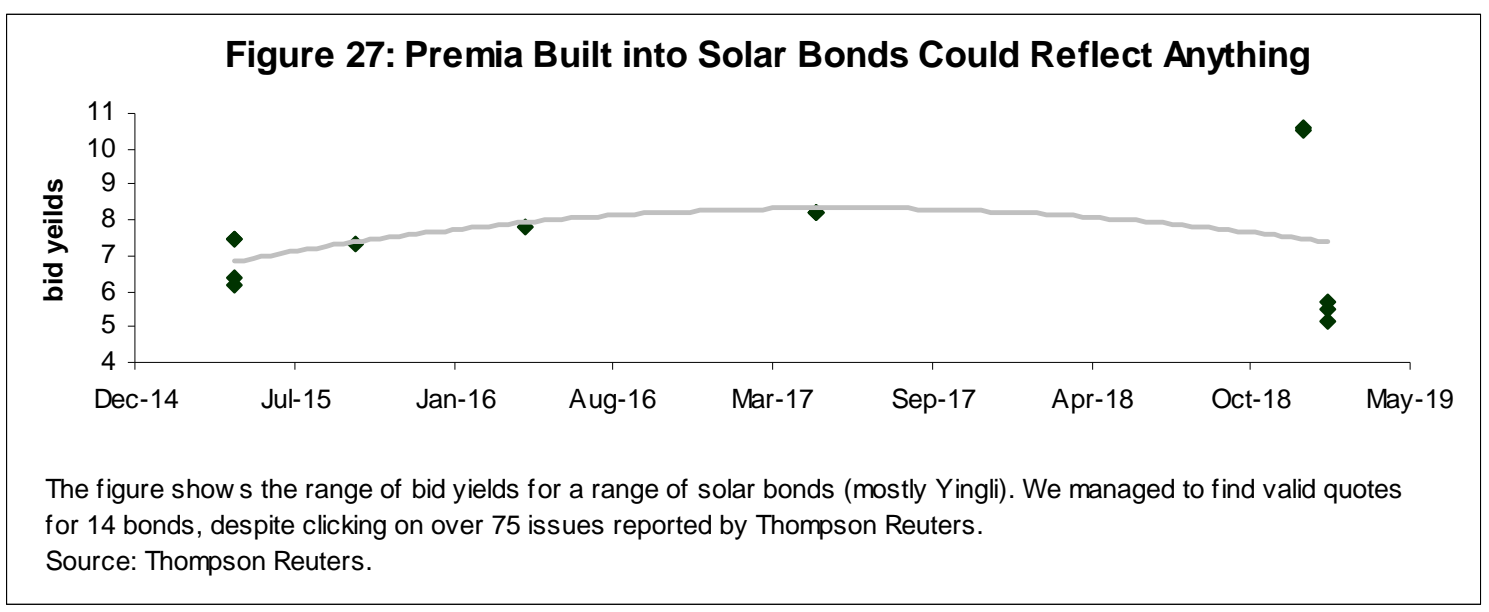

The underlying assets and liabilities of Mainland solar companies (excluding those listed in the US) come to over $\$ 70$ billion. Figure 28 shows total assets and total liabilities for the roughly 60 Mainland photovoltaic producers we could find financial data for. ${ }^{131}$ Total assets (as shown on the y-axis) came to $\$ 43$ billion at the end of 2012. Total liabilities came to $\$ 28$ billion. These assets and liabilities reflect the span of potential securities which Hong Kong intermediaries could offer. As we will describe in more detail shortly, both solar assets and liabilities can be securitised and sold to third-parties. Solar companies' debt in particular represents a fertile ground for securitisation. Undoubtedly, the banks and other intermediaries holding the loans of Mainland solar companies would happily part with some of these loans' risk in exchange for a receiving a slightly lower interest rate.

liquidity or default risk. In many cases, we found incomplete information, large differences between ask and bid prices and even negative yields.

${ }^{131}$ We limited our search to Standard Industrial Classification code 3674 in order to avoid including companies which did not provide solar energy equipment. As such, our data does not represent the entire industry. We include US listed companies in the figure -- but generally exclude these US-listed companies in our later analysis. We exclude these companies as US financial firms are clearly (as we show throughout the paper) better at securitising and selling assets of all kinds. Thus, these companies would not want to securitize assets and sell them in Hong Kong. 


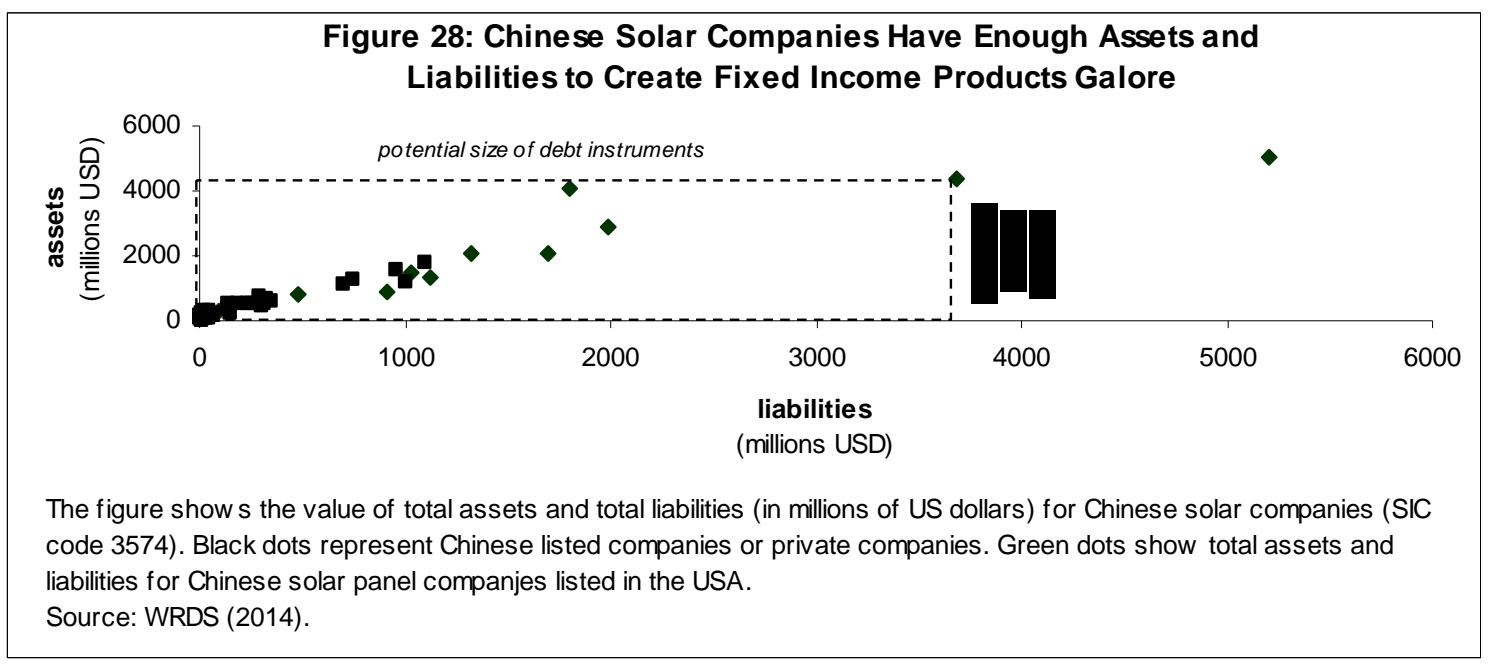

Hong Kong's inability to provide information about even bonds (much less other more exotic types of debt instruments) makes the city an unlikely venue for debt securitisation and trading. Finding information on Mainland solar debt instruments proves an almost impossible task. The HKMA and SFC provide aggregate information about bond purchases and sales. However, sources of information about specific bonds remains lacking. Interestingly, lack of information on bond availability correlates with geography. Figure 29 shows the differences in the way each jurisdiction's major exchange lists bonds. The UK clearly serves as best practice - with an ease in finding and using bond information clearly applicable for all kinds of investors.

\section{Figure 29: Differences in Public Accessibility of Information about Exchange- Traded Debt Instruments}

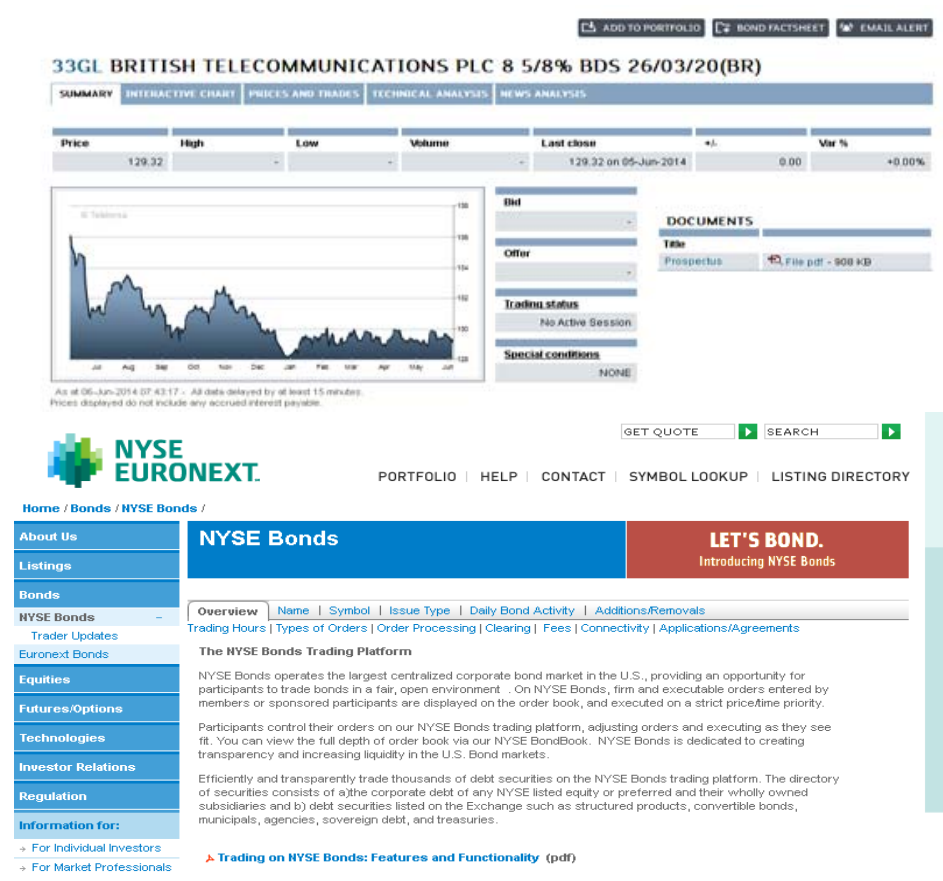

The London Stock Exchange provides a one-stop shop for bond investors. Investors can download data, prospectuses and other analytical information. Special site apps allow for customisable analysis.

The NYSE provides a platform for finding information about bonds. The java app did not work when we tried

it. However, bond information appears all over the internet suggesting vigorous contracts with info-mediaries who redistribute bond information through sites like Morningstar and Yahoo. 


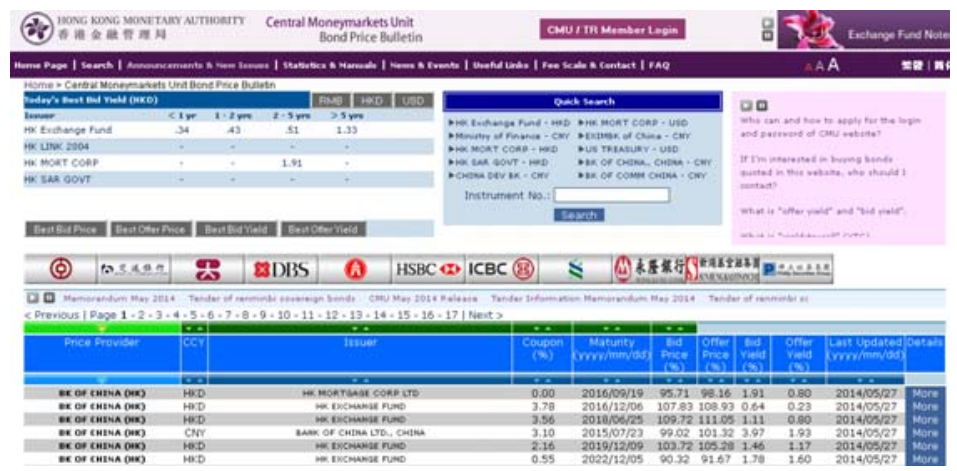

The HKMA Moneymarkets Unit

provides information on bonds, but

without a search and without

integration with intermediary price

providers. As such, the investor must

go to the site to find non-

downloadable information.

Why does the Hong Kong exchange - and its regulators like the HKMA and SFC - fail to provide the same level of service as the other exchanges? The "structuralist view" (which we described earlier in the paper) of Hong Kong as an international financial centre wrongly views Hong Kong Stock Exchange, the HKMA and SFC staff as too stupid (for lack of a better word) to adopt more advanced web-based software. Such a silly view assumes either regulators do not know about the difficulties the lack of such software poses, do not know how to hire the workers needed to put such a system in place or do not know how to pass regulation needed to collect and disseminate such information.

A "contingency-based view" of financial regulation in Hong Kong clearly provides a better explanation for Hong Kong's lagging bond information reporting practices. First, the government remains split on whether to focus its marketing efforts on the Mainland or in the US/EU. Only recently have "road shows" started - and any internet presence directed specifically at non-Hong Kong residents is clearly lacking. Such an attitude reflects Hong Kong's geography - with close ties to the Mainland. Second, jurisdictional issues between the SFC and HKMA may weaken incentives for one of these organisations to take the lead in requiring the collection and dissemination of bond prices. If bond trading succeeds in Hong Kong, it is unclear who would get the credit. As such, neither the HKMA nor SFC have a strong incentive to require the Hong Kong Exchange to develop public information in bond trading. Regulations which encourage the regulators to adopt a marketing perspective (as we describe in this paper) would improve trading in Mainland solar liabilities and other kinds of securities in Hong Kong.

\section{Securitising other solar company assets}

Solar panels themselves represent a \$100 million dollar financing opportunity for Hong Kong financial institutions ready to work in this market. Figure 30 shows the potential electricity generated in various Mainland administrative regions - according to the sunlight that region receives. As shown, much of the electricity (and thus demand for solar panels) falls in the West. ${ }^{132}$ New solar panel production in 2015-2016 should equal roughly 20 gigawatts (according to the national plan and estimates from sources we have

\footnotetext{
${ }^{132}$ In practice, the actual demand for these panels may lie in the Eastern provinces (which want the electricity generated and profits from that generation). We simplify away the issue of cross-country power transmission for now -- as very long-distance electricity transport remains relatively under-developed.
} 
already cited). We conservatively estimate average cost to the customer of about $\$ 5$ per watt. ${ }^{133}$ If an average solar panel produces 200 watts, then 20 billion watts (or 20 gigawatts) requires the equivalent of 100 million solar panels. One-hundred million panels represent 100 million assets which residential or commercial customers can either buy outright or lease. Of course, these simplistic and potentially misleading estimates conceal almost as much as they reveal. Nonetheless, for our purposes, such an estimate suffices for understanding the order-of-magnitude of the potential financing opportunities posed to Hong Kong-based financial intermediaries.

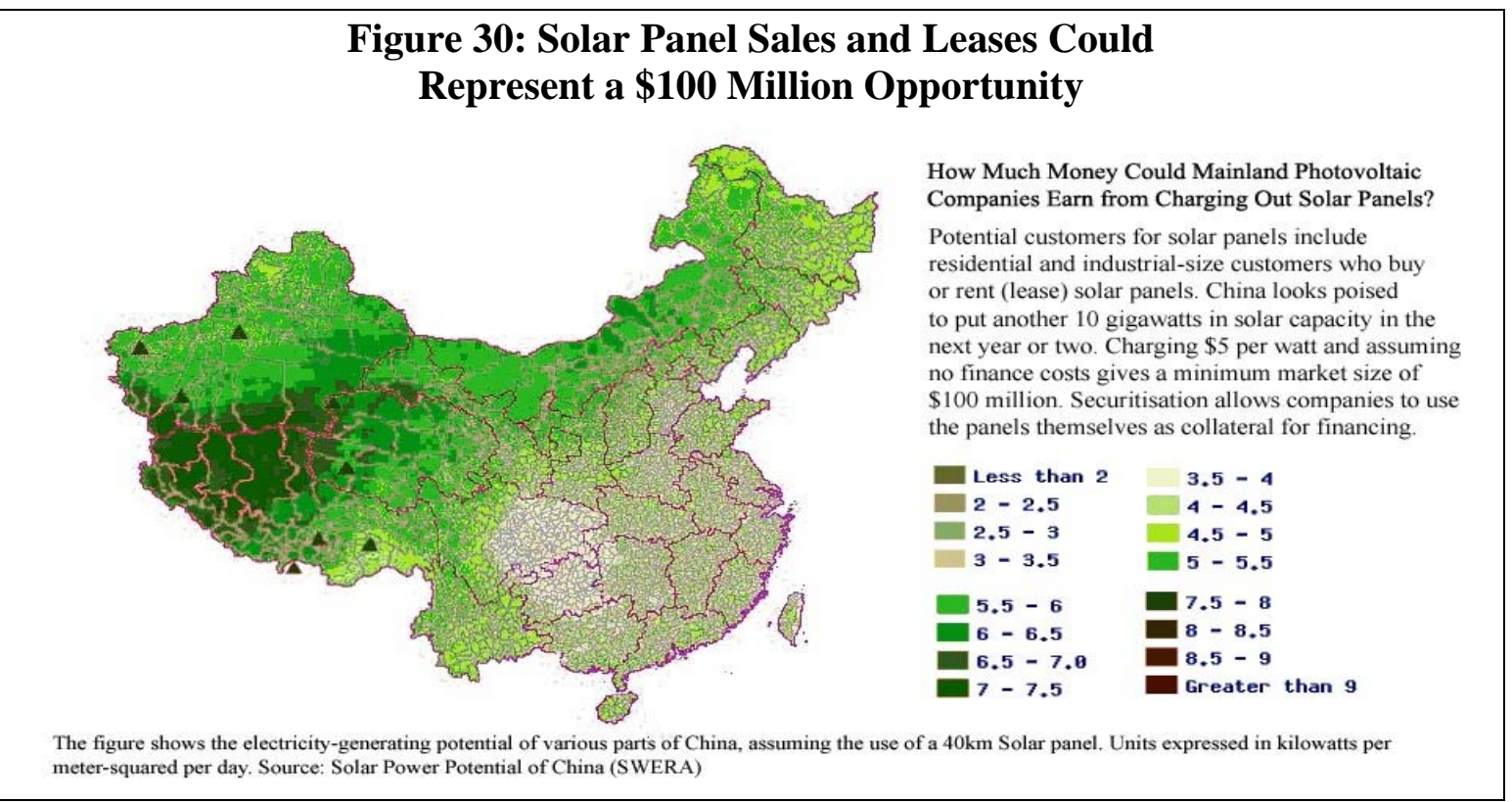

Hong Kong (and other) finance companies can provide value to solar electricity consumers because of the geographical and inter-temporal (across time) mismatch between solar production and incomes. Figure 31 shows the distribution of GDP per capita across the Mainland's various administrative units. As shown. most solar production should occur in the West (given sunlight intensities). However, most of the country's income lies in the Eastern provinces. Moreover, like any investment, a residential investment of about $\$ 20,000$ pays itself back only over a number of years (15 or more depending on the amount of sunlight the area receives). Finance providers help investors in Chinese Western regions raise money they do not possess. They also help solar panels come into existence today based on income lying in the future.

\footnotetext{
${ }^{133}$ The figure shows the amount of sunlight various Chinese regions receive. To arrive at our $\$ 1$ billion market size, we started with estimated new solar panel production in 2015-2016 (of about 20 gigawatts). We then arrived at an average cost to the customer of about \$5 per watt, based on global trends and assuming a constant geometric decline in solar panel prices based on historical experience. See K. Branker, M. Pathak and J. Pearce, A review of solar photovoltaic levelized cost of electricity, RENEW. \& SUSTAIN. ENER. REV.15, 2011. .
} 


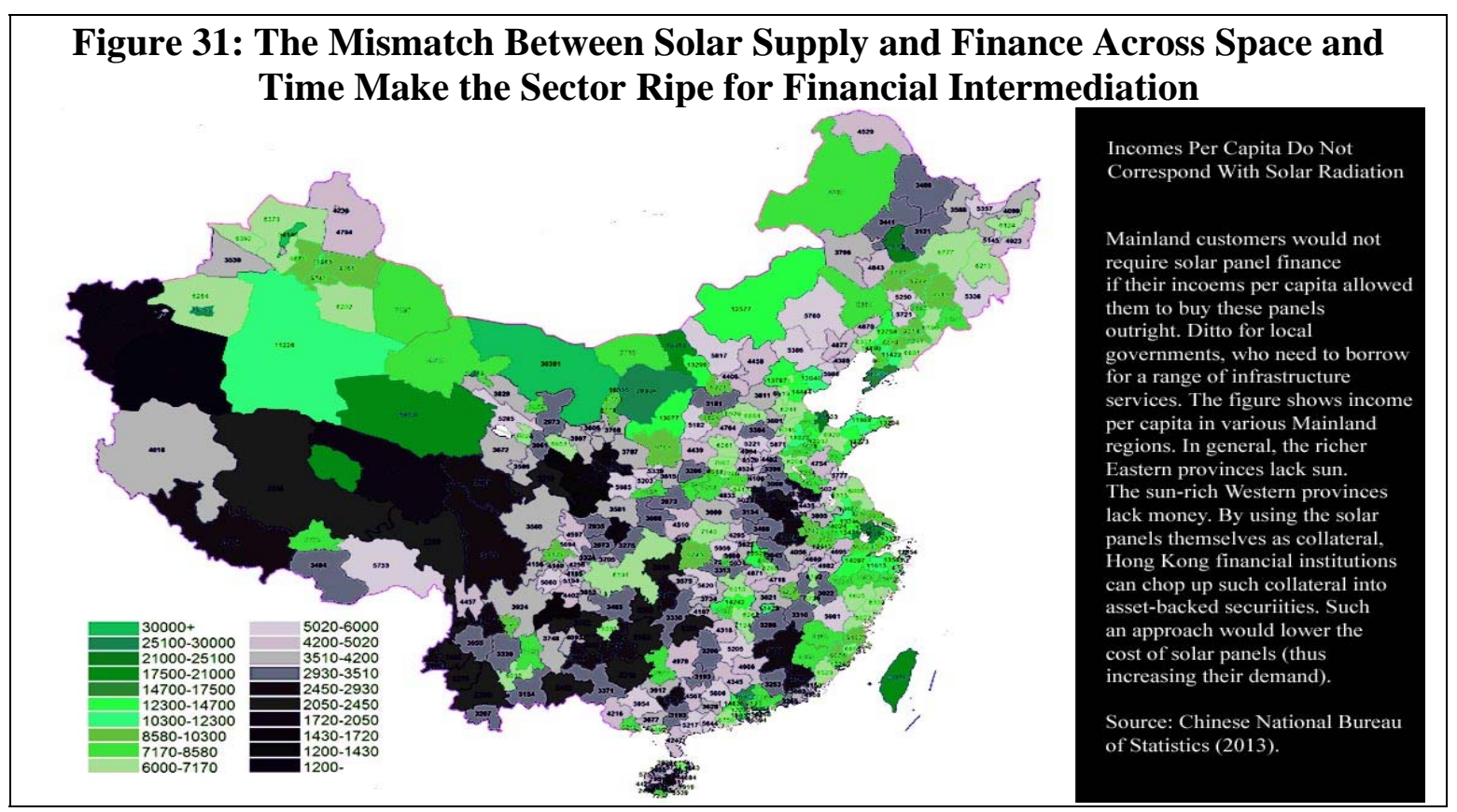

Packaging solar panel assets into bundles (based and risk and resold to other investors) can help improve returns and match risks. More risk-tolerant investors will want higher returns (and thus willingly assume higher levels of risk) from photovoltaic asset investments than highly risk averse ones. ${ }^{134}$ How might Hong Kong-based financial institutions slice the Mainland's roughly $\$ 100$ million in solar panel assets into tranches? Figure 32 shows the possible tranches associated with a broader offer of Mainland solar panel assets (both residential and commercial). ${ }^{135}$ Just like in the US, Mainland solar panel producers can sell (or lease) the panels to retail-facing companies on the Mainland. ${ }^{136}$ Just like in the US, finance companies (or the producers themselves) can sell securities having these panels (and their associated income streams) as collateral. Breaking these panels assets (and their income streams) into securitised tranches clearly helps focus risks and returns offered to investors.

\footnotetext{
${ }^{134}$ Fink describes how US law and practice in solar securitisation helps match securitized tranches with the risk-return profiles of photovoltaic investors. See Andrew Fink, Securitize Me: Stimulating Renewable Energy Financing by Embracing the Capital Markets, 12 U. OF NH LR 1, 2014, available online.

${ }^{135}$ We have treated residential and commercial solar panels similarly to make our analysis easy to understand. Naturally, photovoltaic technologies have large differences in materials, operation, size, lay-out and other features within and between residential and commercial sectors. Providing readers with more detailed (and thus accurate) estimates increases our argument's complexity enormously, without adding extra insight.

${ }^{136}$ We ignore the possibility of Mainland companies creating subsidiaries or affilitates with would sell and lease solar panels in other markets like India, Thailand and other promising markets we have previously identified.
} 


\section{Figure 32: Hypothetical Offering of Solar Panel-Backed Securities}

\begin{tabular}{|c|c|c|c|c|}
\hline $\begin{array}{l}\text { Tai Yang } \\
\text { Solar } \\
\text { Series }\end{array}$ & Description & offering & $\begin{array}{l}\text { risk } \\
\text { (prob. of } \\
\text { default) }\end{array}$ & yield \\
\hline Series 1 & $\begin{array}{l}\text { uses solar panels with safest collateral, } \\
\text { high income and low government debt } \\
\text { regions }\end{array}$ & $\$ 40 \mathrm{~m}$ & $1 \%$ & $7 \%$ \\
\hline Series 2 & 4 & $\$ 20 \mathrm{~m}$ & $3 \%$ & $9 \%$ \\
\hline Series 3 & & $\$ 15 m$ & $5 \%$ & $12 \%$ \\
\hline Series 4 & & $\$ 13$ & $7 \%$ & $14 \%$ \\
\hline Series 5 & $\nabla$ & $\$ 7$ & $12 \%$ & $17 \%$ \\
\hline Series 6 & $\begin{array}{l}\text { collateralises panels without collateral and } \\
\text { with high debt governments/households }\end{array}$ & $\$ 5$ & $20 \%$ & $35 \%$ \\
\hline \multicolumn{5}{|c|}{$\begin{array}{l}\text { The figure shows a hypothetical asset-backed securities offer in Hong Kong for a series of Mainland solar } \\
\text { panel asset-backed securities. We have allocated panel values to each of six possible series. Series differ } \\
\text { depending on the risk of solar panel purchasers defaulting on solar panel loans (or outright purchase) or } \\
\text { lease agreements. The yield reflects the extra financing costs solar panel users need to pay (and thus } \\
\text { interest going to the holders of these asset-backed securities). }\end{array}$} \\
\hline
\end{tabular}

Hong Kong financial institutions can create value by securitising other kinds of assets as well. On the asset side of Mainland photovoltaic company balance sheets sit receivables, plant, property and equipment, investments in partner companies and so forth. Pawning off these assets (or revenue flows attached to these assets) in packaged securities can help improve photovoltaic companies’ balance sheets. ${ }^{137}$ Selling liabilities can also help improve cash flow while potentially saving on financing costs (we previously showed that the cost of capital for Mainland solar electricity providers is relatively high). In general, the prospects for securitising various forms of Mainland solar assets look promising. The overall securitisation market looks poised to reach 3 trillion RMB in the next 4 years. ${ }^{138}$ Mainland Chinese law makes securitisation difficult - providing strong incentives to cut up and sell such assets in Hong Kong instead. ${ }^{139}$ While surrogate methods of securitisation exist on the Mainland (like the creation and sale of covered bonds), Hong Kong provides a much better venue for slicing, dicing and selling these types of solar-backed securities. ${ }^{140}$

Mainland photovoltaic producers' securitizable assets and liabilities (like accounts receivables and payable) come in at 650 billion RMB. Figure 33a shows the value of

\footnotetext{
${ }^{137}$ In theory, Mainland photovoltaic companies might improve their balance sheets by keeping the underlying assets and selling off residual cash flows from those assets. Short-term cash flow would improve (at the expense of future cash flow) - increasing book and market values of these companies in the near-term.

${ }^{138}$ See Daniel Ren, Market for asset-backed securities could reach 3tr yuan by 2018, SCMP 2 JUNE, 2014, available online.

${ }^{139}$ Asset securitisation remains extremely new on the Mainland. Much rulemaking about securitisation focused on inter-bank credit asset securitisation. See E\&Y, Securitization in China, 2014, available online.

${ }^{140}$ We do not focus on the legal technicalities of Chinese financial law (and particularly the comparative advantages of securitisation as opposed to the issue of covered bonds) in order to focus on our paper's main topic. For a discussion of covered bonds as a superiour method of offer asset-backed securities in China, see Steven Schwarcz, Securitization, Structured Finance, and Covered Bonds, 39 J. CoRP. L. 129, 2014.
} 
some of these assets and liabilities. Of these, some of the most risky solar companies (as measured by ratios of total liabilities to total assets) represent more than half of the total value of such securitizable assets and liabilities. ${ }^{141}$ Securitising assets and liabilities from the safer and less leveraged photovoltaic companies can provide guaranteed cash flow and hive off collection risk to risk neutral. ${ }^{142}$ Selling assets and liabilities from the more highly leveraged photovoltaic companies can provide higher yields to investors - and even reduce the risk of bankruptcy of some of the more highly leveraged companies. Figure 33b shows the value of one of the most tangible types of asset which Hong Kong financial institutions can securitise - namely plant, property and equipment. The value of these "hard assets" alone comes to $\$ 7$ billion. The figure also shows rates of return on assets (as measured by retained earnings) for companies binned into each risk category. Companies with the lowest liabilities-to-asset ratios also had the highest returns - of roughly $13 \%$ at the end of 2012. Yet, the medium-leveraged photovoltaic companies had the highest returns - of about $17 \%$. Investors who could sequester particular assets from this group would have returns (and thus risks) different from simply investing in photovoltaic companies individually or as a group.

\footnotetext{
${ }^{141}$ We measure riskiness of investing in the these solar companies underlying assets and liabilities by total liabilities-to-assets ratios as a simple measure. Building more advanced risk models would exponentially increase the complexity of our paper -- without adding any insights. The reader should keep in mind though that the risk measure we use represents a simple "heuristic" to help us spin our argument.

${ }^{142}$ Chinese law still poses obstacles to the collection of such receivables. As such, we talk about a future situation where the various issues around contracting for third-party ownership of receivables liabilities has been settled. See Jon Woo-Jung, The Assignment of Receivables under the Chinese Contract Law and Some Suggestions, 3 PEKING U. J. Legal STUD. 119, 2012.
} 


\section{Figure 33a: Range of Mainland Solar Companies' Assets and Liabilities Provide the a Rich Basis for Securitisation}

\begin{tabular}{|c|c|c|c|c|c|}
\hline & & & & $\begin{array}{l}\text { penulti- } \\
\text { mately } \\
\text { risky }\end{array}$ & \\
\hline accounting item & anche & & & tranche & Why interesting for investors \\
\hline $\begin{array}{l}\text { Current Assets Total } \\
\text { (millions) }\end{array}$ & 6,210 & $\mathbf{8 , 4 7 0}$ & 15,475 & 24,590 & $\begin{array}{l}\text { collateralisation against short-term debts } \\
\text { and offer revenue streams }\end{array}$ \\
\hline $\begin{array}{l}\text { Long-term assets ex. } \\
\text { PPE }\end{array}$ & 320 & 1,740 & 1,675 & 4,595 & $\begin{array}{l}\text { Long term assets provide long term } \\
\text { collateral as well as revenue streams } \\
\text { with different profile of risks and returns }\end{array}$ \\
\hline Accounts Payable & 315 & 1,250 & 3,325 & 10,520 & $\begin{array}{l}\text { Payables can be factored. Also } \\
\text { securitisation of these payables allows } \\
\text { for potentially lower financing costs } \\
\text { Capital expenditures provide for collateral }\end{array}$ \\
\hline Capital Expenditure & 580 & 760 & 2,310 & 5,560 & $\begin{array}{l}\text { as well as basis for lending at below- } \\
\text { prime interest rates } \\
\text { Attractive for cash management services }\end{array}$ \\
\hline Cash & 4,545 & 4,670 & 6,530 & 7,360 & $\begin{array}{l}\text { and other financial advisors } \\
\text { Securitisation (known as "shadow } \\
\text { banking") can provide resources for }\end{array}$ \\
\hline Cost of Goods Sold & 910 & 4,410 & 7,905 & 23,590 & $\begin{array}{l}\text { expanding scale of production } \\
\text { Some companies provide financing and }\end{array}$ \\
\hline $\begin{array}{l}\text { Financing Activities - } \\
\text { Net Cash Flow }\end{array}$ & 520 & 775 & 2,200 & 5,650 & $\begin{array}{l}\text { others accept -- both providing } \\
\text { opportunities for financial intermediaries }\end{array}$ \\
\hline $\begin{array}{l}\text { Notes Payable - Short } \\
\text { Term borrowing }\end{array}$ & 37 & 280 & 2,430 & 11,390 & $\begin{array}{l}\text { Provides for higher interest rate and } \\
\text { higher risk lending opportunities }\end{array}$ \\
\hline Total Gross PPE & 1,424 & 8,220 & 14,955 & 30,010 & $\begin{array}{l}\text { Provides lower risk collateral for } \\
\text { securitisation } \\
\text { Provides another basis for factoring - with } \\
\text { various forms of receivables possessing } \\
\text { differing dearees of risk }\end{array}$ \\
\hline & & & & & differing degrees of risk \\
\hline
\end{tabular}

millions of RMB (SIC code 3674) at the end of 2012. We divided companies into potential tranches based on risk of default as proxied by total liabilities-to-assets ratios. We used total liabilities to asset ratios of $10 \%, 25 \%, 50 \%$ and $75 \%$ as the thresholds for defining which companies' assets belonged to which tranche. Returns to assets show the weighted average of each companies' retained earnings in 2012 expressed as a percent of total assets (with each companies' proportion of total assets in each tranche as the weighting factor).

Figure 33b: Value of Plant, Property and Equipment Assets in Non-US Listed Mainland Solar Sector Tops US\$7 Billion

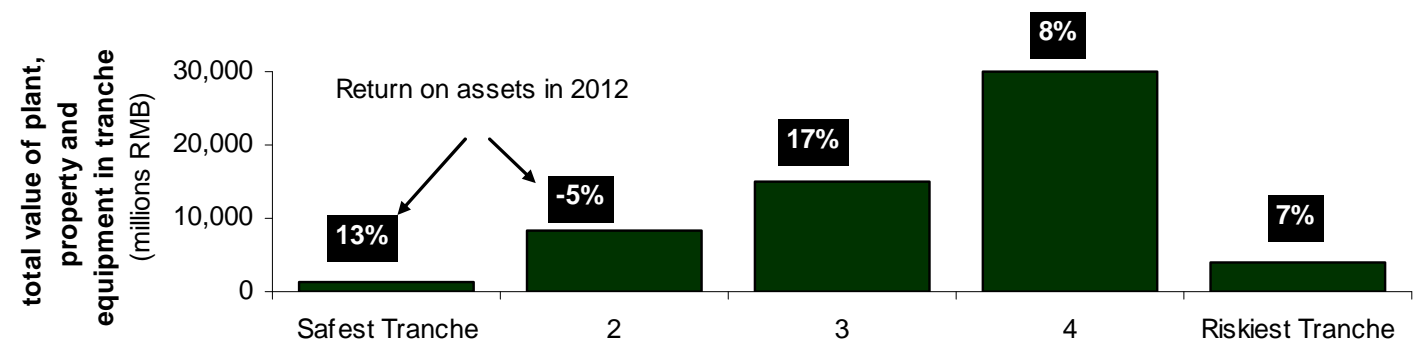

The figure show s the total value of non-US listed Mainland solar companies' plant, property and equipment (SIC code 3674) at the end of 2012. We divided companies into potential tranches based on risk of default as proxied by total liabilities-to-assets ratios. We used total liabilities to asset ratios of $10 \%, 25 \%, 50 \%$ and $75 \%$ as the thresholds for defining which companies' assets belonged to which tranche. Returns to assets show the w eighted average of each companies' retained earnings in 2012 expressed as a percent of total assets (w ith each companies' proportion of total assets in each tranche as the w eighting factor).

Source: WRDS (2014), w ith calculations by authors. 
The use of securitised receivables provides an excellent illustration of how Mainland solar assets can contribute to a balanced portfolio. Figure 34 shows "risks" of investing in Mainland solar companies (with risks defined as the variance in the streams of such receivables). We compare these risks with the correlation between these receivables and the Hong Kong market index. Companies in the integrated circuit-photovoltaic space provide total receivables which positively and negatively vary with the Hang Seng Index (as well as those whose receivables had little or no correlation with the Index). Moreover, Mainland photovoltaic companies’ receivables have risk profiles which may make them useful investments for foreign investors. These companies' total receivables had a correlation coefficient of 0.43 with the FT North American Index and -0.50 with the FT Japan Index in the last 10 years. Such data mean that for North Americans, securities which provide exposure to Mainland photovoltaic companies' receivables would offer a partial hedge against market risk. In Japan, these receivables would have provided an extremely effective hedge. Hong Kong-based financial institutions able to package these securities and sell them to these American and Japanese investors would have created value - by increasing investors' returns and reducing portfolio risk.

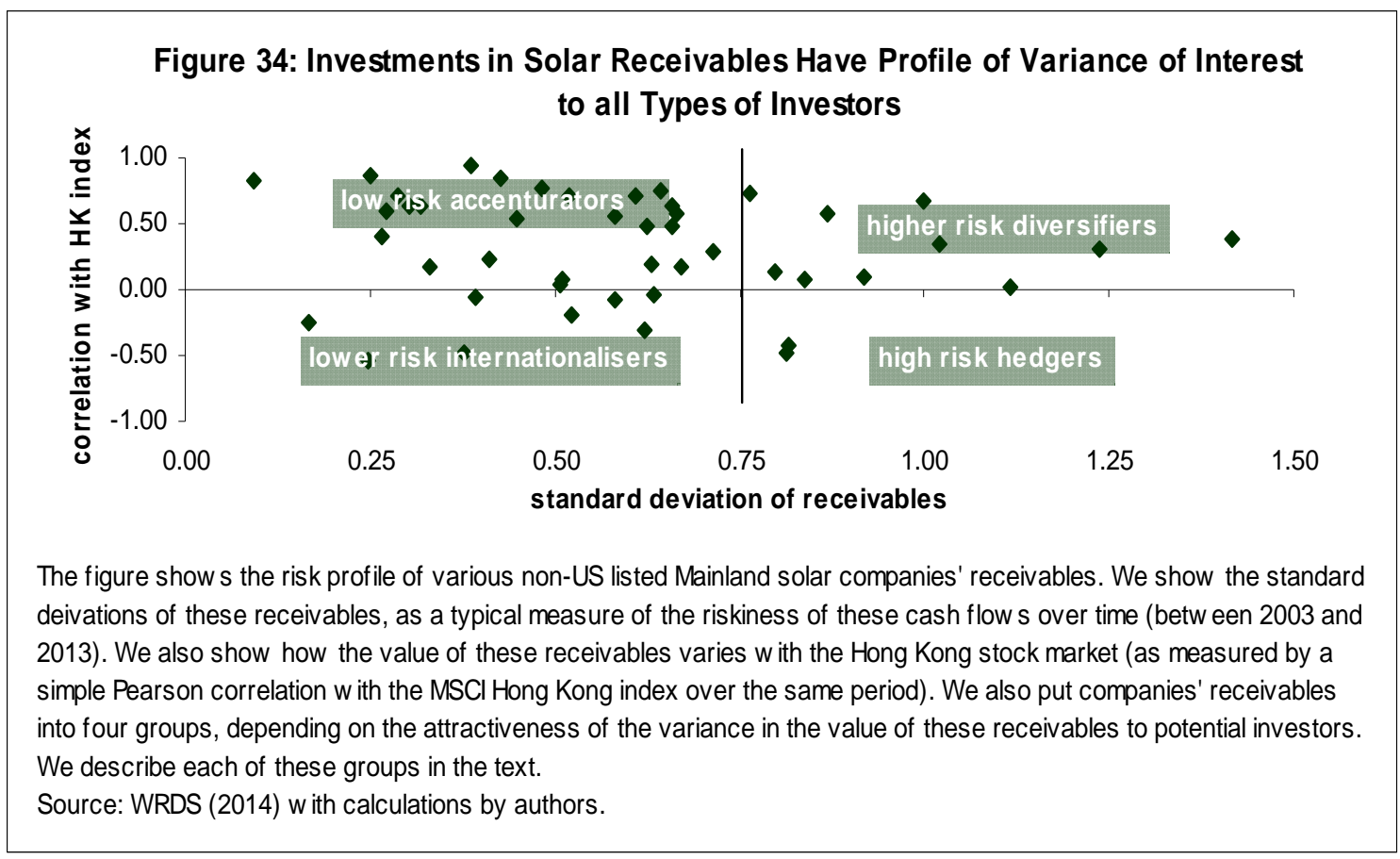




\section{Hong Kong as a Mainland Solar Company Securitisation Centre}

\section{Why securitise solar assets?}

The decrease in global asset securitisation - combined with the potential of solar company asset securitisation - provides amble opportunities for Hong Kong investors. ${ }^{143}$ Figure 35a shows the value of asset-backed commercial paper, collateral debt obligations and asset-backed securities world-wide. ${ }^{144}$ Until 2009, the value of these securities easily amounted to over \$1 trillion. After the crisis, the value of new securitisations has fallen. Such securitisation can only deepen Hong Kong's financial markets. Asset-backed securities and obligations represent an important part of the swap trades which provide short-term liquidity to banks and companies alike. Hong Kong holds roughly $\$ 94$ billion of US government agency asset-backed securities and about \$1 billion of corporate ones. ${ }^{145}$ Yet, we "make" very little of these asset-backed securities (outside of the mortgage sector) by ourselves. The total value of these securitized assets weigh in at less than half of their pre-crisis level. If Hong Kong financial institutions can originate and sell these types of securities, they can profitably participate in the recovery of a multi-billion dollar industry.

Figure 35a: Global Collapse in Securitisations Represents an Opportunity for Hong Kong

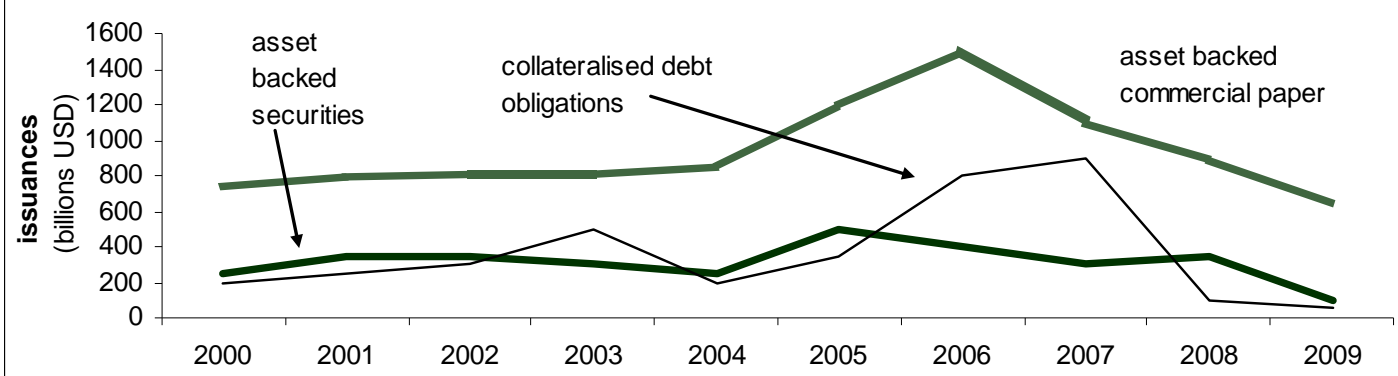

The figure show s the issuance of "private label" securitisation by type.

Source: Kiff et al. (2009) at Figure 2.2

\footnotetext{
${ }^{143}$ Securitisation in general provides many advantages for companies like those in the Mainland's photovoltaic industry. Skarabot, as early as 2002, showed that asset-backed securities may return more money to investors in a bankruptcy than typical equity shares. Gorton and Souleles show that asset-backed securities may match far more closely with individual investors' risk and reward appetites than other types of securities. Unlike under an equity shareholding arrangement, investors in asset-backed securities can pick exactly which assets (and thus market opportunities) they want exposure to. See Jure Skarabot, Securitization and Special Purpose Vehicle Structures, available online. See also Gary Gorton and Nicholas Souleles, Special Purpose Vehicles and Securitization, In Mark Carey and Rene Stulz, THE RISKS OF FINANCIAL INSTITUTIONS, 2004, available online.

${ }^{144}$ See John Kiff, Andy Jobst, Michael Kisser, and Jodi Scarlata, Restarting Securitization Markets: Policy Proposals and Pitfalls, In IMF, Global Financial Stability RePORT: NAVigating The FinANCIAL CHALLENGES AHEAD, 2009, available online.

145 See Federal Reserve Board, Value of foreign holdings of U.S. securities, by major investing country and type of security as of June 30, 2012, at Table 6, available online.
} 
Within the asset-based securitisation sector, solar securities probably have the most room to grow. Figure 35b shows the value of solar structured assets, compared with other kinds of structured securities in the US. ${ }^{146}$ Auto loan, credit card and student loan securitisations make up the bulk of such securitisations in the US- with potential solar securitisations representing only a fraction of the market total. If solar-backed assets growth to the same level as level as securitisations on assets like human capital (student loans) or equipment, and if Mainland markets look anything like their US counterparts, the market for solar-backed securities should grow by at least $\mathbf{\$ 2 0}$ billion. HMoreover, the experience from securitising and selling solar-backed securities can help Hong Kong's financial institutions grapple with the complexities of selling proven lucrative assets like auto loans and credit card asset-backed securities (originated on Mainland assets of course). ${ }^{147}$

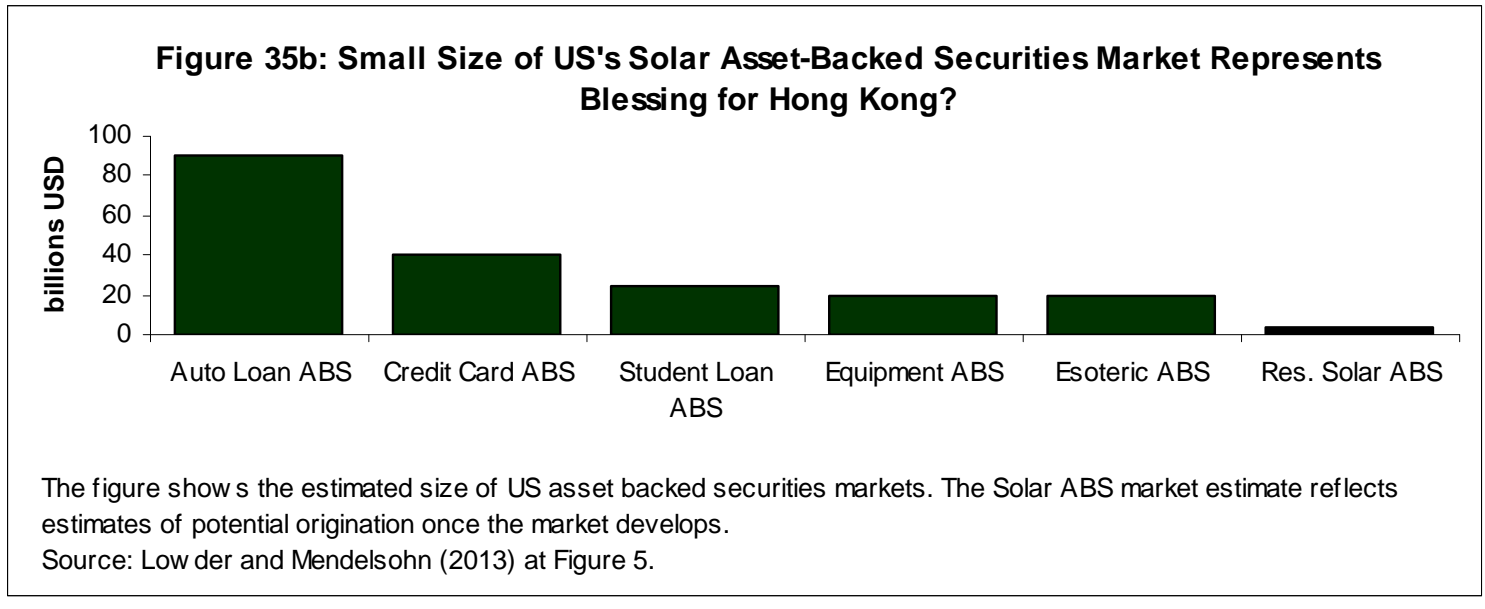

Yet, Hong Kong's financial institutions have a long way to go before they can hope to compete in the creation and sale of asset-backed and debt-backed securities. We know very little about how much of these securities Hong Kong financial institutions actually make. ${ }^{148}$ Yet, some data do exist. Figure 35c shows the number of single security assetbacked securities issued in Hong Kong (as a proxy for the importance of Hong Kong's structured securities internationally). ${ }^{149}$ As shown, Hong Kong securitisation comes in far below those of other international financial centres on the sale of single-stock derivative contracts. Reassuringly however, China ranks even lower. As such, Hong Kong's

\footnotetext{
146 See Travis Lowder and Michael Mendelsohn, The Potential of Securitization in Solar PV Finance, Technical Report, NREL/TP-6A20-60230, 2013, available online.

${ }^{147}$ Market sizes in Hong Kong are too small to make such securitisation very profitable for Hong Kong situated assets. Thus, the rapid development of Hong Kong's securitisation sector relies on access to Mainland markets (and underlying assets like credit card and auto debt).

148 The HKMA provides regular monitoring of debt, derivatives and structured securities. However, they include mortgage-backed securities in their analysis - leaving the analyst unable to figure out the volume of "productive assets" be securitised, structured and sold. See HKMA, Results of surveys on selected debt securities and off-balance sheet exposures to derivatives and securitisations, 2013, available online.

149 See Daniel Bergstresser, The retail market for structured notes: Issuance patterns and performance, 1995-2008, HBS WP, 2008, available online.
} 
financial institutions can compete in the cross-border sale of securities written on Mainland assets and liabilities -- though their competition will likely come from UK and German interlopers rather than native companies.

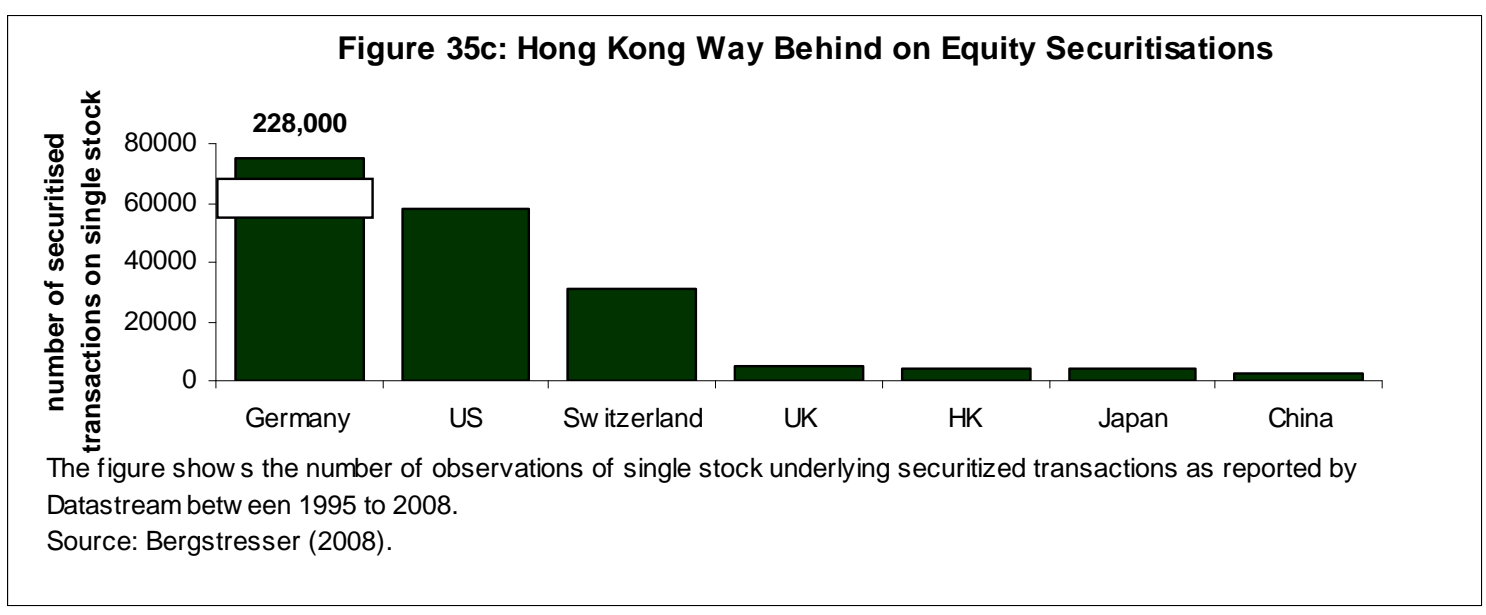

Despite its large potential, solar securitisations appear unlikely on the Mainland for the foreseeable future. Mainland regulators have made significant progress in putting regulations in place which govern such securitisation - after a significant hiatus in the post-crisis period. ${ }^{150}$ Despite Schwartz's plea to open the Golden Sun Demonstration Project's assets for securitisation, such prospects seem remote. ${ }^{151}$ A number of issues remain - including institutional support, credibility, and an adequate regulatory structure putting into practice regulations like Administrative Measures on Pilot Projects of Credit Assets Securitisation as well as the Regulatory Measures on Financial Institutions Undertaking Credit Assets Securitization (among others) ${ }^{152}$ Even in the US, the recent sale of "sunshine-backed bonds" shows the market has a long way to go. ${ }^{153}$ If Hong Kong can tap these markets during the Mainland's adjustment period, securitisation markets will likely stay with Hong Kong.

Securitisation lowers solar companies’ costs, making funding through securitisation a preferred method of finance for many types of solar assets and liabilities. Figure 36 shows the levelised cost of solar-generated electricity under a range of financing options. ${ }^{154}$ Debt financing - and specifically financing through selling asset-backed obligations - results in cheaper solar finance than traditional finance. Equity, while

\footnotetext{
${ }^{150}$ See Takeshi Jingu, Significance of Restart of Asset Securitisation in China, NRI WP 176, 2013, available online.

${ }^{151}$ See Louis Schwartz, Securitization of Solar Assets in China, available online.

${ }^{152}$ For an overview of some of these rules, see Yuwa Wei, Asset-Backed Securitization in China, 6 Rich. J. GLOBAL L. \& BUS. 225, 2007.

${ }^{153}$ Tracy Alloway, Sunshine-backed bond to go on sale, FT, 2013, available online. See also Diane Cardwell, Bonds Backed by Solar Power Payments Get Nod, available online.

${ }^{154}$ Levelised cost of electricity refers to the price which electricity providers need to charge in order to pay their inputs and give investors a market rate of return. For the figure, see Michael Mendelsohn and David Feldman, Financing U.S. Renewable Energy Projects Through Public Capital Vehicles: Qualitative and Quantitative Benefits, NREL/TP-6A20-58315, 2013, available online.
} 
providing cheaper money, can also actually increase the cost of capital to photovoltaic cell producers (if the US experience applies to the Mainland). These findings suggest that simply listing on the Hong Kong Exchange may not improve Mainland solar companies' competitiveness (by lowering their cost of capital). Hong Kong financial law and government policies needs to find ways of encouraging financial institutions to create and trade debt and debt-based securities in order to provide competitive capital to the Mainland's (and others') solar companies.

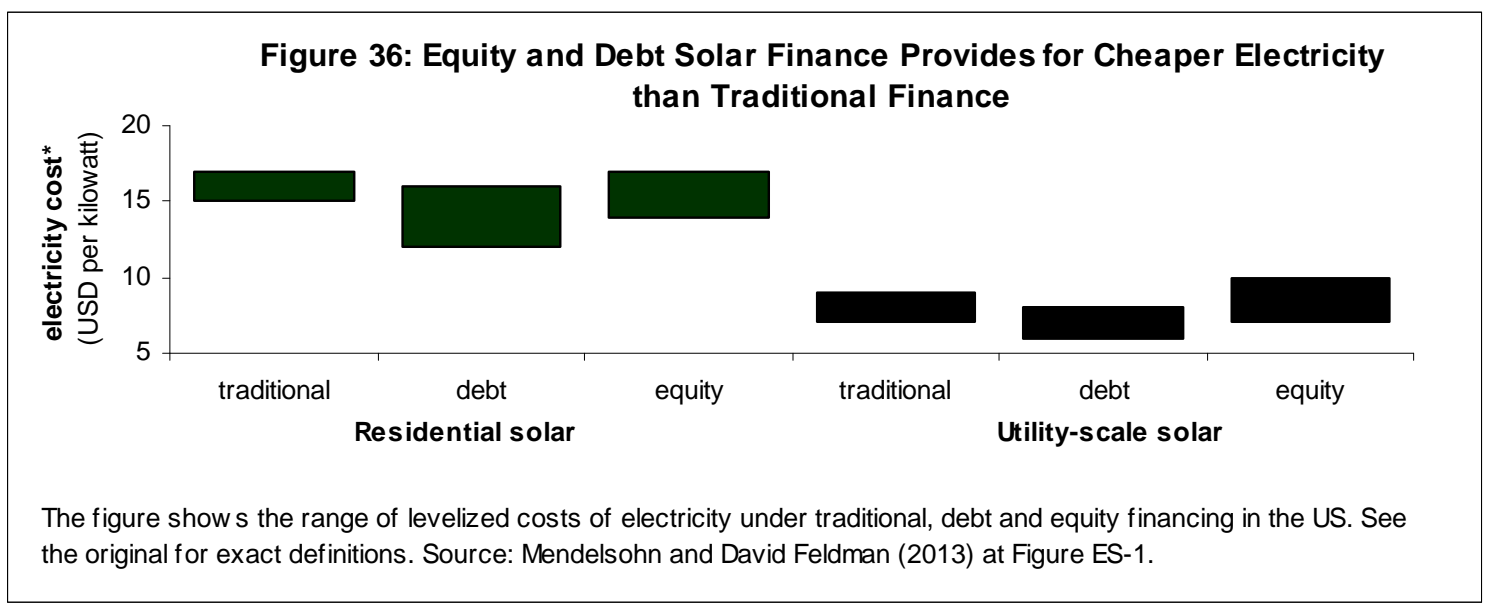

Many analysts agree that securitisation represents the best form of finance for solar investments. Unlike conventional bank or stock investments, the sale of securitised assets would allow for a larger investor base and better targeting of risk-return profiles. ${ }^{155}$ If the US experience serves as any guide, the Mainland solar energy provision and financing markets will likely segment along geographical lines. Figure 37 shows the development of solar finance companies across the US. ${ }^{156}$ We focus on finance companies -- rather than solar panel or electricity distributors -- in order to discuss the consumer financing side of the industry. As shown, some companies (like Sun Edison) and Clean Power Finance offer services nationally. Yet, we see a range of companies which specialise on regions (groups of states) -- like Solar City, Skyline Innovations, and Tioga. Others focus only on one state -- like BGE Hone and CT Solar Lease. Such differentiation between solar finance providers strongly suggests differences in consumers' preferences and needs across states which one or more national finance providers can not serve (at least not yet). If each of companies we list in the figure issues stocks, bonds, and asset-backed securities, this would generate 57 different issues. ${ }^{157}$

\footnotetext{
${ }^{155}$ For a fuller discussion, see Samantha Jacoby, Solar-Backed Securities: Opportunities, Risks, and the Specter of the Subprime Mortgage Crisis, 162 U. PA. L. REV. 203, 2014, available online.

${ }^{156}$ See Steve Horton, Solar Finance: List of Solar Finance and Leasing Companies, available online. See also Samantha Jacoby, Solar-Backed Securities: Opportunities, Risks, and the Specter of the Subprime Mortgage Crisis, 162 U. PA. L. REV. 203, 2014, available online.

${ }^{157}$ Namely, we assume that Amberjack Solar would have its own traded shares, bonds and asset-backed securities (3 different issues), BGE Home similarly (for 3 more) and so forth. Naturally, if these companies issue preferred shares, different types of debt instruments and different types of asset-backed securities, the number of issues can easily exceed 100 types of instruments that investors can buy to gain exposure to the risks and returns in the solar finance sector.
} 
Figure 37: Niche Solar Finance Companies Provide Access to Geographically Specific Risks as well as Differing Risk/Return Profiles

\begin{tabular}{|c|c|c|c|}
\hline $\begin{array}{l}\text { Solar Financing } \\
\text { Company }\end{array}$ & Available in: & $\begin{array}{l}\text { Solar Financing } \\
\text { Company }\end{array}$ & Available in: \\
\hline Amberjack Solar & $\mathrm{MA}, \mathrm{NJ}$ & Solar City & CA, MA, MD, WA \\
\hline BGE Home & MD & Soltage & CT, MA, NJ \\
\hline BrightGrid Solar & AZ, CA,CO, HI, NJ & Skyline Innovations & $\begin{array}{l}\text { AZ, CA, FL, Mid-Atlantic } \\
\text { states }\end{array}$ \\
\hline Citizenre & $\begin{array}{l}\text { AR, CT, DE, GA, HI, LA, MA, } \\
\text { MD, ME, MN, NH, NJ, NY, OK, } \\
\text { OR, RI, VA, VT, WA, WY }\end{array}$ & Sun Edison & Nationwide \\
\hline CentroSolar & $\mathrm{AZ}, \mathrm{CA}, \mathrm{NJ}$ & SunPower & $\begin{array}{l}\text { AZ, CA, CO, HI, MA, NJ, } \\
\text { NY, PA }\end{array}$ \\
\hline $\begin{array}{l}\text { Clean Power } \\
\text { Finance }\end{array}$ & Nationwide & Sun Run & $\begin{array}{l}\text { AZ, CA, CO, HI, MA, NJ, } \\
\text { OR, PA }\end{array}$ \\
\hline $\begin{array}{l}\text { Constellation En } \\
\text { ergy/ BGE Home }\end{array}$ & MD & Sungevity & $\begin{array}{l}\text { AZ, CA, CO, DE, MA, } \\
\text { NY, NJ, MD }\end{array}$ \\
\hline CT Solar Lease & CT & $\begin{array}{l}\text { Technology Credit } \\
\text { Corporation }\end{array}$ & MA \\
\hline $\begin{array}{l}\text { First Light Solar } \\
\text { (FLS Energy) }\end{array}$ & NC, SC, GA and TN & Tioga & $\begin{array}{l}\text { AZ, CA, CO, CT, HI, MA, } \\
\text { MD, NJ, NV, OR, OR, PA }\end{array}$ \\
\hline $\begin{array}{l}\text { Mercury Solar - } \\
\text { Financing }\end{array}$ & CT, MA, NJ, NY, PA & Vivint Solar & NY, HI, UT \\
\hline GroSolar & PA & & \\
\hline
\end{tabular}

Note: Solar production in 2012 reached the following levels: California (983Mw), Arizona (709Mw), New Jersey (391 Mw), Nevada (226), Massachusetts (123), North Carolina (122Mw), Hawaii (114), Colorado (103), Maryland (80), New York (56), others (434). Total equals $3341 \mathrm{Mw}$.

Sources: Horton (2013) and Jacoby 2013 at Fig. 2.

The geographical spread of solar finance companies in the US suggests three things for Hong Kong as it develops its solar securities markets. First, Hong Kong's financial institution can create literally hundreds of different securities from the likely range of solar R\&D, producer, operations, finance and other parts of the value chain. In the US example, we argued that ambitious securitizers could produce 57 different issues of solar finance-based securities. For Hong Kong-based financial firms looking to do the same for Mainland-based producers and financiers, we could expect similar numbers. ${ }^{158}$

Second, providing securities based on the securitised assets and liabilities of these kinds of solar financing firms could provide Hong Kong, Mainland and international investors with focus on particular geographical markets they want to take solar risks and returns in, while offering diversification. Third, we could even see securities aggregators issuing mixtures of these securities in different combinations as pre-packaged products. Let's continue with our example as illustrated above. If investors wanted exposure only to Pennsylvania, Massachusetts, and Maryland, they could buy a pre-packaged fund with securities only from GroSolar, Technology Credit Corp., and BGE Home. Diversity in the underlying tastes and technologies of solar financing alone suggest Hong Kongbased financial institutions could offer literally hundreds of different securitised

\footnotetext{
${ }^{158}$ China has fewer provinces than the US has states. However, the diversity between Chinese provinces (and thus differences in tastes and technologies) greatly exceeds that of the US in general (though of course US states have large differences in types of consumers within states and even buildings!).
} 
products. ${ }^{159}$

A financial centre also provides the analytical tools which can help keep Mainland photovoltaic companies' cost of capital low. Solar project costs of capital usually rise if finance clients (the households and companies using the solar panels) default on their loans/leases and if the company must keep excess capital to cover obligations implicit in its asset-backed securities. ${ }^{160}$ Having some Hong Kong financial firms which focus on solar investments can help ensure solar-backed risks are correctly priced -- thus lowering Mainland solar companies' cost of capital. Figure 38 shows the wedge between the rate that investors want and the rate that photovoltaic manufacturers must pay for capital. ${ }^{161}$ These wedges increase as default rates among solar panel users (borrowers) increase and as companies need to increase the value of panels they bundle into securities. ${ }^{162}$ If companies or financiers miscalculate these values, costs of capital can rise (as financiers over-provision capital or over-estimate investors' required returns).

Figure 38: Excess Capital Costs Paid on Solar Projects Due to Early Contract Termination and Excess Collateral Requirements

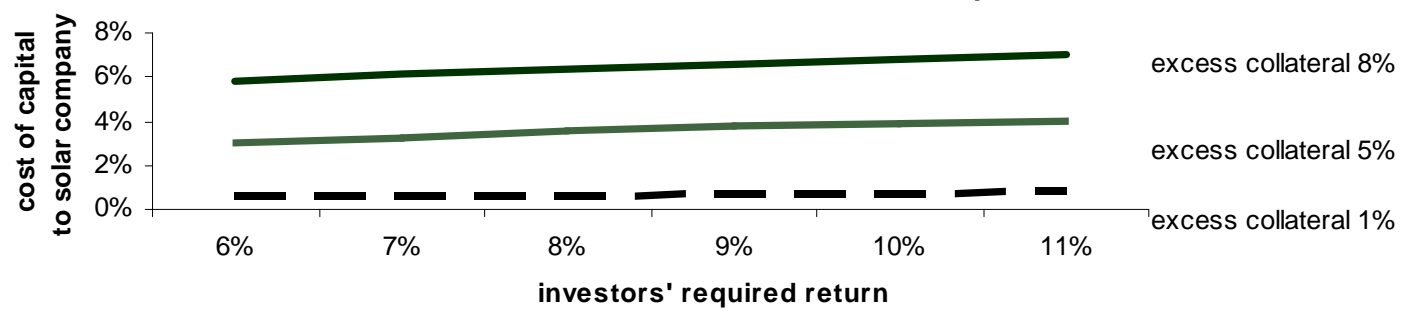

The figure show s the cost of capital to photovoltaic producers for a 5\% early contract termination rate and the effect of over-collateralisation. Solar projects need to over-collateralise (or pledge the value of solar assets in excess of the value of the securities) in order to receive a sufficiently high credit rating.

Source: Alafita and Pearce (2014) at Table 2.

\footnotetext{
${ }^{159}$ We exclude in our discussion "covered bonds" - which provide guarantees of repayment in case of default or non-payment in the underlying assets. Some analysts have suggested that Chinese securities laws make recovery easier for covered bonds than securitised assets. As our paper is already complex enough, we do not want to explore this issue further. See Robert Freedman \& Patricia Hammes, US Solar: Of PPA Securitisations, horizons \& hurdles, INFRASTRUCTURE J. , 2011, available online.

${ }^{160}$ A wide variety of factors determine the cost of capital. We talk about those factors that policy can affect. See Geoffrey Klise, Jamie Johnson, and Sandra Adomatis, Valuation of Solar Photovoltaic Systems Using a Discounted Cash Flow Approach, Appraisal J., 2013.

Geoffrey Klise, Jamie Johnson, and Sandra Adomatis,

${ }^{161}$ For a calculation of the range of values, see Alafita and J.M. Pearce, Securitization of residential solar photovoltaic assets: Costs, risks and uncertainty, Energy Policy, 2014, available online.

${ }^{162}$ Asset-backed securities posses solar panel as underlying assets. The prices of these panels may vary depending on age, supply and demand and other factors. An asset-backed security traded for $\$ 1,000$ which allows investors to recover $\$ 1,100$ worth of solar panels at current prices will naturally have a better rating than one which allows investors to recover only $\$ 900$ worth of underlying solar panels.
} 
Hong Kong provides additional opportunities for securitising solar assets which are unavailable in the US. First, Hong Kong-based (and/or listed) solar financing firms have a stronger implicit guarantee of bailouts in case of financial difficulty. The international media reported extensively on Chaori Solar's default. ${ }^{163}$ Yet, at roughly the same time, LDK Solar received loans from China Development Bank (a state-owned and controlled financial institution) after its bond default. ${ }^{164}$ While Chaori's default tests the Government's resolve to support solar companies, no one believes the Chinese state has completely removed implicit support for solar companies. ${ }^{165}$ Such a guarantee thus should cover Hong Kong investors putting their money in these companies. Second, Hong Kong financing and securitisation firms can offer economies of scale in securitisations which US investment firms would find hard to match. ${ }^{166}$ As we previously showed, the solar financing market in the US still rests at a nascent stage - with markets divided by state. These Chinese experience shows vividly that scaling-up can occur quickly -- offering a potentially larger market China than even the US or the EU. Third, and related to these points, the lack of customer credit histories represents a far less problem for Hong Kong investors than US investors. Credit rating agencies - like Standard \& Poor's - have noted that lack of credit histories for solar assets make these assets hard to rate (and thus price). ${ }^{167}$ Given implicit guarantees by the Mainland government and potential to attract investors who best know the risks, the risks seem remote. $^{168}$

Hong Kong provides a superiour venue for selling solar securities than the US for other reasons as well. First, the reliability of long-term cash flows has bedevilled the US solar market for some time. ${ }^{169}$ With rental contracts at 20 years and average home ownership tenures at 13 years, the mismatch between ownership tenure and lease period creates a risk. However, such moves are less frequent on the Mainland. Second, solar panel producer and operations companies achieve significant cost-savings (and thus higher profitability) from larger scales. We already provided data showing China's strong advantages in certain export markets and parts of the solar supply chain. We also showed data indicating that the largest Chinese solar companies split their listings between Hong Kong and New York. As the Mainland solar industry consolidates, having a single source

\footnotetext{
163 See Bloomberg, China Gets 1st Onshore Bond Default as Chaori Doesn't Pay, 2014, available online.

${ }^{164}$ See Bloomberg, LDK Solar Gets 2 Billion Yuan Bank Loans After Bond Default, 2014, available online.

165 Recent declarations by the State Council (China's supreme executive body) clearly signal the government's resolve to continue to support the industry. See Sydney Morning Herald, China reaffirms support for solar PV industry, 2014, available online.

${ }^{166}$ Borod worries that that even the US's potentially large market for securitised solar assets would not achieve sufficient scale to attract demand and sufficiently lower origination costs. Citing Bloomberg in 2011, he claims that bond values for securitised rooftop solar panel contracts would come to only about $\$ 430$ million. The securitisation of all commercial rooftop contracts only bring about \$730 million in new solar bonds. These amounts come to much less than the values we presented earlier for securitisations on the Mainland. See Ronald Borod, The Devil in the Details of Solar Securitization, 39 PRACTICAL INTERNATIONAL CORPORATE FINANCE STRATEGIES 7, 2013, available online.

${ }^{167}$ See Andrew Giudici, Jeong-A Kim, Brian Yagoda, Will Securitization Help Fuel the U.S. Solar Power Industry? 2012, available online.

${ }^{168}$ Increasing Hong Kong’s securities markets will, hopefully, attract more Mainland institutional investors who can monitor risks more closely.

${ }^{169}$ See Borod at 2.
} 
of equity, debt and securitised debt funding (namely Hong Kong) could provide benefits for aggregators and specialists working in Hong Kong. ${ }^{170}$ Third, solar financing could benefit from standardized documentation and systematized due diligence - both of technological specifications as well as the financing documents underpinning the installation of that technology. Such standardisation is much easier in a city-state than a country spanning 50 different legal systems and hundreds of solar entities (namely the US). If Hong Kong can quickly settle on such standards for the Mainland before US firms can agree on such a standard, Hong Kong standards could even affect the trajectory of market development. Fourth, the US Dodd-Frank Act requires the sponsor to hold at least $5 \%$ of the risks associated with any securitisation. ${ }^{171}$ Hong Kong does not require such potentially costly risk-retention -- making Hong Kong a more attractive jurisdiction.

\section{Lessons of the Minibond Scandal for Developing a Hong Kong Solar Market}

Despite the promise of photovoltaic securitisation in Hong Kong, many investors do not think of Hong Kong as a securitisation centre due to recent scandals - particularly the Lehman Minibond scandal. Why should investors invest in securitised assets in Hong Kong when such investments have a poor track record? A recent review of securitisation sums up the current situation, "securitisation professionals are continuing to have to look elsewhere in the region for deals given the extremely low level of activity in Hong Kong." 172 The financial crisis - combined with the Lehman mini-bond crisis - led to regulators' and buyers' wariness of structured investments - including asset-backed securities of all types. ${ }^{173}$ Such wariness comes from lumping together asset-backed securities with structured products. Asset-backed securities (like solar bonds) use assets as collateral and as underlying producer of the revenue streams ultimately thrown-off by the securities themselves. To take an example from a recent SolarCity solar bond, "the trust estate [the legal entity used to hold the underlying asset] will consist primarily of all rights, title, and interest of the issuer in a portfolio of solar assets, including customer agreements, solar equipment, permits, manufacturer's warranties, and cash flow associated with the ownership of such assets" (bracketed material ours). ${ }^{174}$ Solar Funding I and Solar Funding II also represent examples of securities (in this case debt-securities) using secured assets to back a medium-term note. ${ }^{175}$ Structured finance usually involves the use of derivatives whose pay-offs depend on particular events - like the continuing existence and operation of a particular solar company or asset. ${ }^{176}$ Packagers often structure these securities like bets -- in order to provide investors with "pure” exposure to

\footnotetext{
170 Borod refers to this as an "aggregation facility."

${ }^{171}$ See Borod at 2.

${ }^{172}$ See Adrienne Showering and Paul McBride, Securitisation in Hong Kong, In Stephen Jaques, GLOBAL SECURITISATION AND STRUCTURED FinANCE 2008, 2008, available online.

${ }^{173}$ We do not have the space to describe the Minibond scandal. For an overview, see Freshfields Bruckhaus Deringer, An overview of the Lehman Brothers minibonds saga, available online.

${ }^{174}$ For an analysis of the instrument, see Xilun Chen and Weili Chen, SolarCity LMC Series I LLC (Series 2013-1), available online.

${ }^{175}$ For these notes’ prospectus, see Solar Funding I and II, 2010, available online.

${ }^{176}$ For more, see Joshua Coval, Jakub Jurek and Erik Stafford, The Economics of Structured Finance, HBS WP 09-060, 2008.
} 
certain risks (and rewards) that holding assets and liabilities directly can not provide. ${ }^{177}$ Solar assets might be structured through "tranching” asset-backed securities (like receivables) into groups with differing risk profiles (as we have illustrated in the examples in the previous sections). In theory, underwriters can write derivatives which pay (or don't pay) depending on any risk chosen in the structured product document.

Yet, the Minibond crisis illustrates our thesis - that Hong Kong's policymakers must focus on structural issues (how to encourage the marketing of productive investments in the real economy) rather than simply tweak financial law governing the process of securities sales. The marketing materials themselves provide a perfect illustration of how the structured product promoters did not market to the right people with the right product. Figure 39 shows an example of an ad used to market the Lehman minibonds. ${ }^{178}$ The ad illustrates our paper's thesis - that policy should encourage banks and broker-dealers in a financial centre to focus on targeting the right investors with the right products. Financial sector policy (and thus law) encouraged marketing minibonds to the general public rather than target individuals who could use their profile of risks and returns to complement other portfolio holdings. ${ }^{179}$ Structured products did not cause the mini-bond crisis. The nature of the minibonds and the marketing process itself caused the scandal.

Figure 39: Minibonds Sold Speculative Bets, Not Shares of Productive Investment

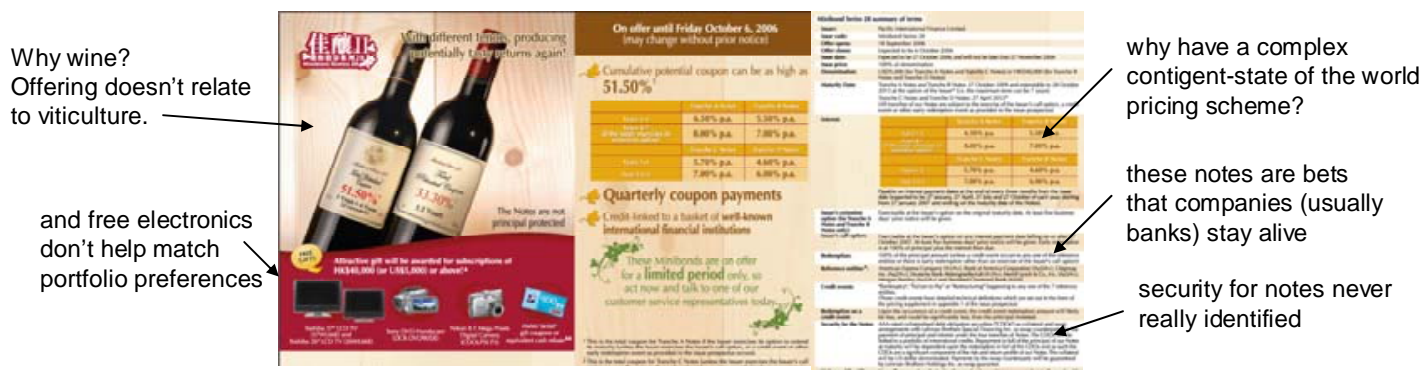

\footnotetext{
${ }^{177}$ For example, a solar-backed structured product could pay 5\% if the underlying solar assets yield 9\% or nothing if they yield less. Such a bet allows investors to increase their risks (and thus returns) -- while offering the securities' originators the opportunity in profit in case the assets are only mildly profitable. ${ }^{178}$ We provide a superficial description of the problems associated with these advertisements in order to focus on our own paper's thesis. For a detailed discussion of the problems with the advertising regime in place at the time, see Andrew Godwin, The Lehman Minibonds Crisis in Hong Kong: Lessons for Plain Language Risk Disclosure, 32 UNSW L. J. 2, 2009, available online.

${ }^{179}$ The SFC, looking for legal rather than structural problems, cited misrepresentation in the sales process, the complexity of the structured products themselves and lack of suitability assessment as the main drivers of the scandal. Their response consisted of increasing the hurdles to purchase, while remaining faithful to a regulatory regime based on disclosure rather than ex-ante rules. If policymakers stepped back and asked what the sale of structured products hoped to achieve in the broader financial system, their recommendations might have been more similar to the ones we make in this paper. See SFC, Issues Raised by the Lehman Minibond Crisis: Report to the Financial Secretary, 2008, available online.
} 
The nature of the minibonds (and other structured products) sold show how the very philosophy of Hong Kong's structured products market has moved away from intermediating funds and towards betting. Figure 40a shows the types of Lehman Brother structured products offered during the Minibond crisis; while Figure 40b shows the companies which had to go bankrupt in order for the bonds not to pay off. ${ }^{180}$ The value of Lehman Minibonds equalled roughly the annual turnover of the Las Vegas Sands (casinos). Each of the series amassed large amounts of investments in securities without any solid underlying assets. Moreover (as shown in the second part of the figure), investors in Hong Kong bet primarily on banks located thousands of miles away. Standard Chartered, HSBC, Citigroup and Bank of America represented the most frequent "reference entities" which investors would wager would not go bankrupt. Hutchinson Whimpoa represents the only "productive" (from the perspective of making goods and services) company on the list. ${ }^{181}$ Financial regulation did not represent the core problem of the crisis. Financial and other institutions which stoked demand and encouraged the supply of inherently unproductive financial securities led to the crisis.

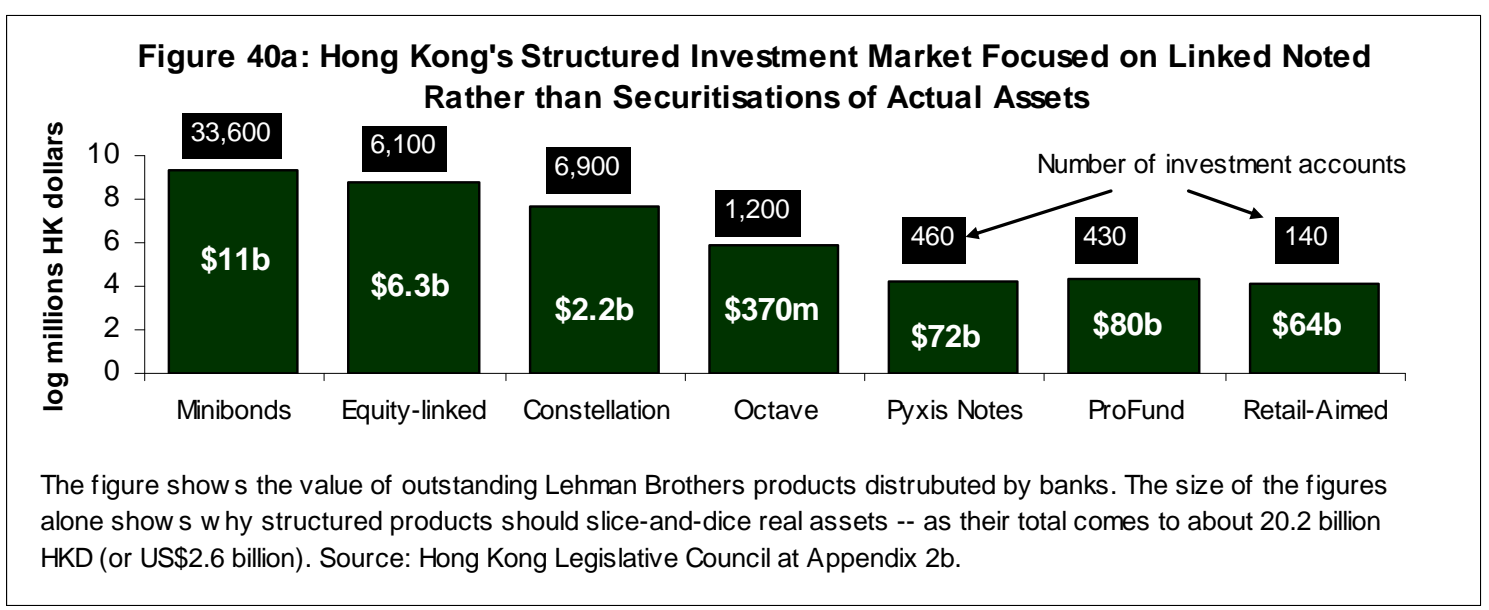

\footnotetext{
${ }^{180}$ See Legislative Council, Report of the Subcommittee to Study Issues Arising from Lehman Brothersrelated Minibonds and Structured Financial Products, 2012, available online.

${ }^{181}$ Economists see the resources spent by banks and other sectors like security services as "transactions costs." In this view, these intermediaries produce nothing directly - instead allow for other sectors of the economy to operate more efficiently.
} 


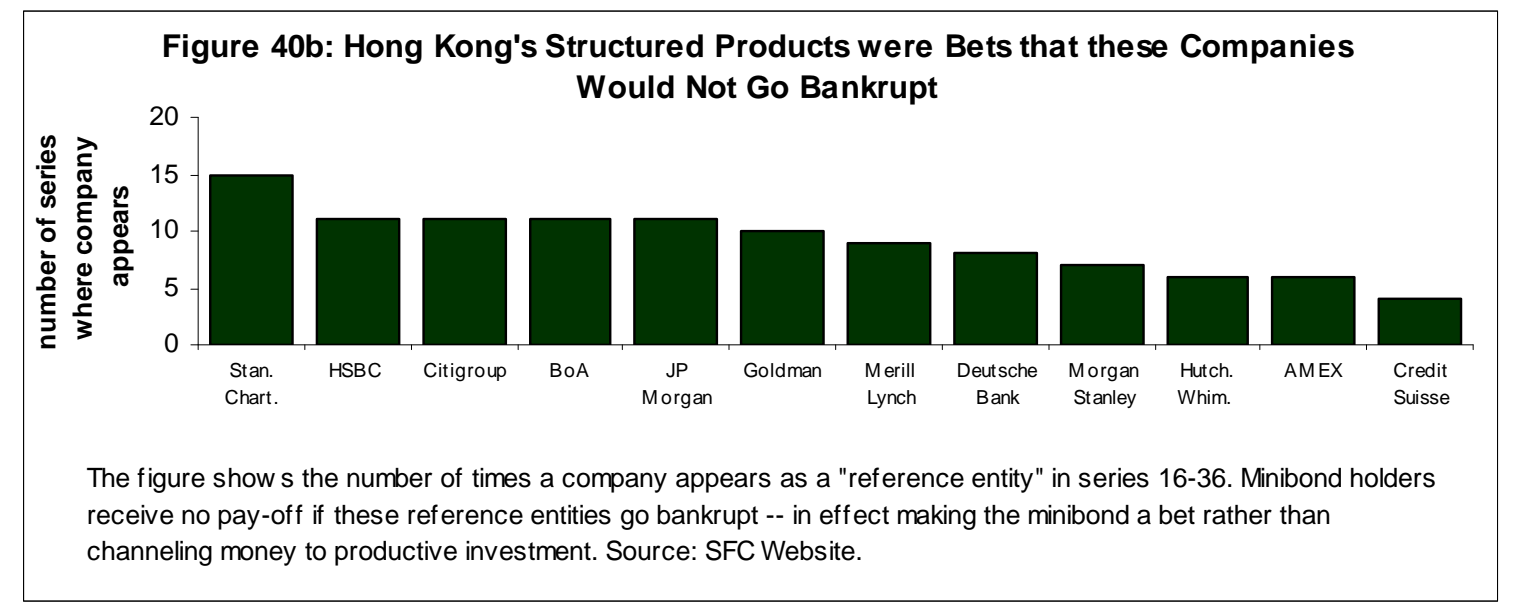

The Government's "structuralist” approach (focusing on best practice sales processes and legal provisions) - rather than taking a "contingency-based" view of the marketing of structured products in general - will not help develop Hong Kong's financial markets. ${ }^{182}$ The Legislative Council and Securities and Futures Commission have claimed that "many lessons have been learnt" from the crisis. Figure 41 summarises the major regulatory changes based on the lessons from the Minibond scandal. ${ }^{183}$ In order to make our discussion more concrete, we focus our discussion of these proposed changes on their likely effect on the development of vibrant financial markets in solar (photovoltaic) assets. Many of the Government's proposed reforms will likely make the offer of photovoltaic structured instruments more difficult - without increasing investors' safety.

Figure 41: Selected Proposed Reforms Still Don't Focus on Real Economy

\begin{tabular}{|c|c|}
\hline Item & n and Impact on Solar \\
\hline Single SFC & Adoption of single rulebook presumably consolidates rulemaking and increases \\
\hline Handbook & compliance. In itself, a cosmetic remedy. \\
\hline Key Fact & Plain-language, fact statements will allow investors to more easily assess \\
\hline Statements & $\begin{array}{l}\text { investment risks and returns. A glance at these statements show, despite plain } \\
\text { English, still long and complex. }\end{array}$ \\
\hline $\begin{array}{l}\text { Oversight of } \\
\text { product arrangers }\end{array}$ & $\begin{array}{l}\text { Product arrangers should be based in Hong Kong and overseeable by SFC. Such an } \\
\text { action focuses on enforcement, and not on SFC's role in promoting development of } \\
\text { cooperation with those it regulates. }\end{array}$ \\
\hline $\begin{array}{l}\text { Eligibility for } \\
\text { issuers, guarantors }\end{array}$ & $\begin{array}{l}\text { Prohibits these classes of arrangers from engaging in activities if they have } \\
\text { disciplinary action against them. Naturally, this would help solar market }\end{array}$ \\
\hline and arrangers & $\begin{array}{l}\text { providers - particularly if plan to make requirements easier for retail access to solar } \\
\text { securities. }\end{array}$ \\
\hline Collateral & $\begin{array}{l}\text { Securitised issuers would need to hold collateral against securitisations. Collateral } \\
\text { would raise costs and hurt securitisations. }\end{array}$ \\
\hline Investo & Requires testing of investors' product knowledge and risk profit (suitability). For \\
\hline
\end{tabular}

\footnotetext{
${ }^{182}$ Linklaters provides an excellent overview of the proposals made in response to the Minibond crisis and the Government's focus on sales processes and potential fraud. See Linklaters, Legco Report-Impact on Providers and Distributors of Structured Financial Products, 2012, available online.

${ }^{183}$ See Alan Ewins, Catherine Husted, Juliana Lee and Joyce Woo, The Lehman Aftermath: Hong Kong and Singapore Regulatory Reforms in the Structured Product Markets World, 5 CAP. MAR. L. J. 3, 2010.
} 
classification

Disclosure of commissions

Post-sale obligations Cooling-off period

Safe harbours

Authorisation for marketing materials

Based on Ewins et al. (2010) mis-selling would help. But wouldn't help protect investors who want to take genuine risks.

Securitised products' distributors should disclose commissions. Such disclosures probably very important if target retail and international investors in a special regime (as we propose in this paper).

Requires on-going communication of updated financial information, potential risks, liquidity and so forth.

Provides investors with chance to change their mind (within a certain number of days). Probably good for solar investors - as risk of losses low and need investors which understand their purchase.

Hong Kong has had difficulty in defining safe harbour areas. As we describe in this paper, extending safe harbour provisions probably good for markets.

Given increased SFC surveillance, can move to post-vetting system - fining firms marketing solar products which violate requirements.

Most commentators rightly - if maladroitly - point out that a regulatory regime which discouraged the production and use of simple and useful information helped add fire to the scandal. Godwin represents one of the most vocal academics arguing for the simplest possible descriptions of the securitised products that investors buy. ${ }^{184}$ Most commentators further point out that the SFC's proposed rules will not increate the clarity, simplicity and usefulness of investor information. ${ }^{185}$ Neither will the HKMA's recommendations - which aim at everything -- from producing "health warnings" labels on documents, producing audio recordings of sales meetings and detailed customer risk assessments. ${ }^{186}$ Nothing in the recommendations addresses the fact that structured product information materials do not tell investors what assets they are buying and whether they match the investors' portfolio needs. ${ }^{187}$

Current structured products materials on file with the SFC probably reduce participation in structured products without necessarily improving investors' knowledge of the mechanics of the investment. Figure 42 shows a sample of investor materials from the SFC's List of Investment Products. As shown from this random sample, the informational materials - while written in simple English - still provide a great deal of information without simple overviews of how the investment works. These voluminous materials use plain English. However, they clearly seem written in a way which protects the writer from liability, rather than informing clients what their money is used for.

\footnotetext{
${ }^{184}$ See Andrew Godwin, The Lehman Minibonds Crisis in Hong Kong: Lessons for Plain Language Risk Disclosure, 32 UNSW L. J. 2, 2009, available online.

${ }^{185}$ See Will Shen, When Complexity Impairs Disclosure - A Critique of SFC's Proposal to Strengthen the Disclosure Regime after the Lehman Minibonds Incident in Hong Kong, 23 EURO. BuS. L. REV. 6, 2012.

${ }^{186}$ HKMA, Report of the Hong Kong Monetary Authority on Issues Concerning the Distribution of Structured Products Connected to Lehman Group Companies, 2011, available online.

187 The SFC's recommendations encouraged investment advisors to conduct suitability checks, in part based on observations from authors like Chang et al. - who find that investors buy more structured products when investment advisors do not check for suitability. As we argue, investors should not merely be "suitable." Structured products should contribute a risk-return profile to their existing portfolio in a way that adds value to the investors' portfolios and provides the company which securitised its assets some competitive market advantage. See Eric Chang, Yongjun Tang and Miao Zhang, Suitability Check and Household Investments in Structured Products, 2013, available online.
} 


\section{Figure 42: Structured Product Investment Materials in Plain English, But Still Don't Describe the Actual Investments}

\begin{tabular}{|c|c|c|}
\hline Instrument & Information and structure & \\
\hline $\begin{array}{l}\text { Non-Principal Protected Unlisted Daily Accrual Equity } \\
\text { Linked Investments Linked to a Basket of Securities } \\
\text { with Call Feature and Optional Knock-In Feature }\end{array}$ & Product booklet - & 229 pages \\
\hline DBS Bank Ltd. & Programme Memorandum - & 29 pages \\
\hline Non-Principal Protected Unl & Financial Disclosure Document - & 177 pages \\
\hline Linked Investments Linked to a Single Security & Product Booklet - & 148 pages \\
\hline China Construction Bank & Programme Memorandum - & 25 pages \\
\hline $\begin{array}{l}\text { Non-principal Protected Unlisted Callable Equity- } \\
\text { Linked Investment Contracts with Potential Cash } \\
\text { Distribution linked to a Basket of Stocks }\end{array}$ & $\begin{array}{l}\text { Financial Disclosure Document - } \\
\text { Offering Circular - }\end{array}$ & $\begin{array}{c}245 \text { pages } \\
51 \text { pages }\end{array}$ \\
\hline Societe Generale & Product Document - & 175 pages \\
\hline $\begin{array}{l}\text { Non-Principal Protected Unlisted Bull Equity Linked } \\
\text { Investments Linked to a Single Security }\end{array}$ & $\begin{array}{l}\text { Term Sheet - } \\
\text { Product Booklet - }\end{array}$ & $\begin{array}{l}7 \text { pages } \\
57 \text { pages }\end{array}$ \\
\hline HSBC & Programme Memorandum - & 206 pages \\
\hline $\begin{array}{l}\text { Non-Principal Protected Unlisted Equity Linked } \\
\text { Investments linked to a Single Stock }\end{array}$ & $\begin{array}{l}\text { Financial Disclosure Document - } \\
\text { Information Memorandum - }\end{array}$ & $\begin{array}{r}383 \text { pages } \\
23 \text { pages }\end{array}$ \\
\hline Bank of China & Product Booklet - & 168 pages \\
\hline
\end{tabular}

As we shall see in the next section, lack of specific information is not specific to structured products. Hong Kong markets in general provide far less useful information to investors than the US or UK. Hong Kong's financial law dictates the incentives to produce investment information. Judging by the quality and reader-friendliness of such information, such financial law falls behind that of the US and UK.

\section{Developing information markets for Mainland Solar Securities}

Deep "investment information markets" can promote the development of Hong Kong as an international financial centre - not only for solar securities but for all kinds of securities. ${ }^{188}$ Financial law which promotes the generation of insightful, reader-friendly and useful company analysis would likely have three effects on the depth of Hong Kong's financial markets. ${ }^{189}$ First, increasing the amount of information simple enough for retail investors would likely increase demand for Hong Kong securities by professional, institutional investors. Professional investors and institutional investors are people too. They often look at the same information sources (like Seeking Alpha and the

\footnotetext{
${ }^{188}$ We refer to investing information "markets" throughout this paper -- as the production and consumption of such information clearly follows market principles. The value of such information depends on its supply and demand and commands a price (even if payment for such information often occurs during the sale of the investments themselves).

${ }^{189}$ More and better information about Hong Kong securities can only benefit investors and companies themselves. For proof of this self-evident statement (albeit from a US context), see Brian Bushee, John Core, Wayne Guay, and Sophia Hamm, The Role of the Business Press as an Information Intermediary, 48 J. OF ACC. REs. 1, 2010.
} 
Wall Street Journal) and other information sources that retail investors do. ${ }^{190}$ Broadening information sources about Hong Kong-traded securities and companies (and solar companies in general) can only enhance overall financial market liquidity and promote efficiency. ${ }^{191}$ Second, having lots of people writing about Hong Kong-listed and traded securities makes secondary market sales easier and priced better. ${ }^{192}$ Lack of information leads to selling "lemons," adverse selection and moral hazard in offering and buying securities. ${ }^{193}$ Having vibrant information markets in Hong Kong-traded securities would reduce investors' reliance on any one source of information -- and possibly even improve investors' performance. ${ }^{194}$ Third, observing how others react to information can provide as much - if not more - information to investors than financial statements, earnings reports and major company events. ${ }^{195}$ Wide-spread media coverage of securities can help bring inside or little-known information in the public's view, increasing the information content of share prices. ${ }^{196}$ Hong Kong's securities regulatory regime based focuses on disclosure rather than authorisation. For disclosure to work (discipline companies), information needs to be shared and discussed.

At first glance, the quality of information investors receive about Hong Kong-listed solar companies (and companies in general) seems comparable to its larger international financial centre peers like New York. Figures 43 show that while the quantity of information about Hong Kong-listed solar companies roughly equals those listed elsewhere, the quality of such information differs. Figure 43a shows the depth of information about major Mainland solar companies listed in Hong Kong and New York. As shown, the number of internet references to various solar panel companies looks

\footnotetext{
${ }^{190}$ Indeed, institutional investors spend more of their time looking at financial media, making the value of such information even greater. Barber and Odean find that institutions may consume more of such information and use it better. See Brad Barber and Terrance Odean, All That Glitters: The Effect of Attention and News on the Buying Behavior of Individual and Institutional Investors, 21 REV. FIN. STUD. 2, 2008.

${ }^{191}$ Returns to investors on stocks which the media generally does not cover exceed those which the financial media covers. This implies that investors have special information. Thus, expanding the amount of information to retail investors about securities would remove these profitable (and unfair?) information asymmetries. See Lily Fang and Joel Peress, Media Coverage and the Cross-section of Stock Returns, 64 J. OF FIN. 5, 2009.

192 Numerous studies find that webboard and other postings have a statistically significant (albeit small) effect on equity prices. See Werner Antweiler and Murray Frank, Is All That Talk Just Noise? The Information Content of Internet Stock Message Boards, 59 J. OF FIN. 3, 2004.

${ }^{193}$ For an example of this problem in the mortgage-backed securities financial services segment, see Chris Downing, Dwight Jaffee and Nancy Wallace, Is the Market for Mortgage-Backed Securities a Market for Lemons? 22 REV. FIN. STUD. 7, 2009.

${ }^{194}$ In the US, information aggregators have started to consolidate ratings from a wide range of analysts into “consensus forecasts.” Acaedmics have not yet definitively established whether the performance of such consensus estimates and analysis based on the aggregation of analysts' analyses beats individual estimates. Yet, the high demand for such aggregation in the US shows that investors value these services. See

${ }^{195}$ For one study, see Timothy Pollock, Violina Rindova, and Patrick Maggitti, Market Watch: Information and Availability Cascades Among the Media and Investors in the U.S. IPO Market, 51 ACAD. MANAGE. J. 2, 2008.

196 See Paul Tetlock, Does Public Financial News Resolve Asymmetric Information? 23 REV. FINANC. STUD. 9, 2010.
} 
similar between Hong Kong-listed and non-Hong Kong listed solar companies. ${ }^{197}$ Figure 43b shows the depth of information provided by solar companies listed in Hong Kong and in other jurisdictions. As shown, most US-listed solar companies have some form of web-casting of financial, operational and other results. Hong Kong-listed Mainland solar companies often provide very little information. Figure 43c represents one example of the general trend in Hong Kong to provide very succinct information about companies. The information provided by both the companies themselves and their analysts consists of 2-3 line announcements about earnings or major news events. The telegraphic analysis favoured in Hong Kong likely results in part from its financial law. ${ }^{198}$
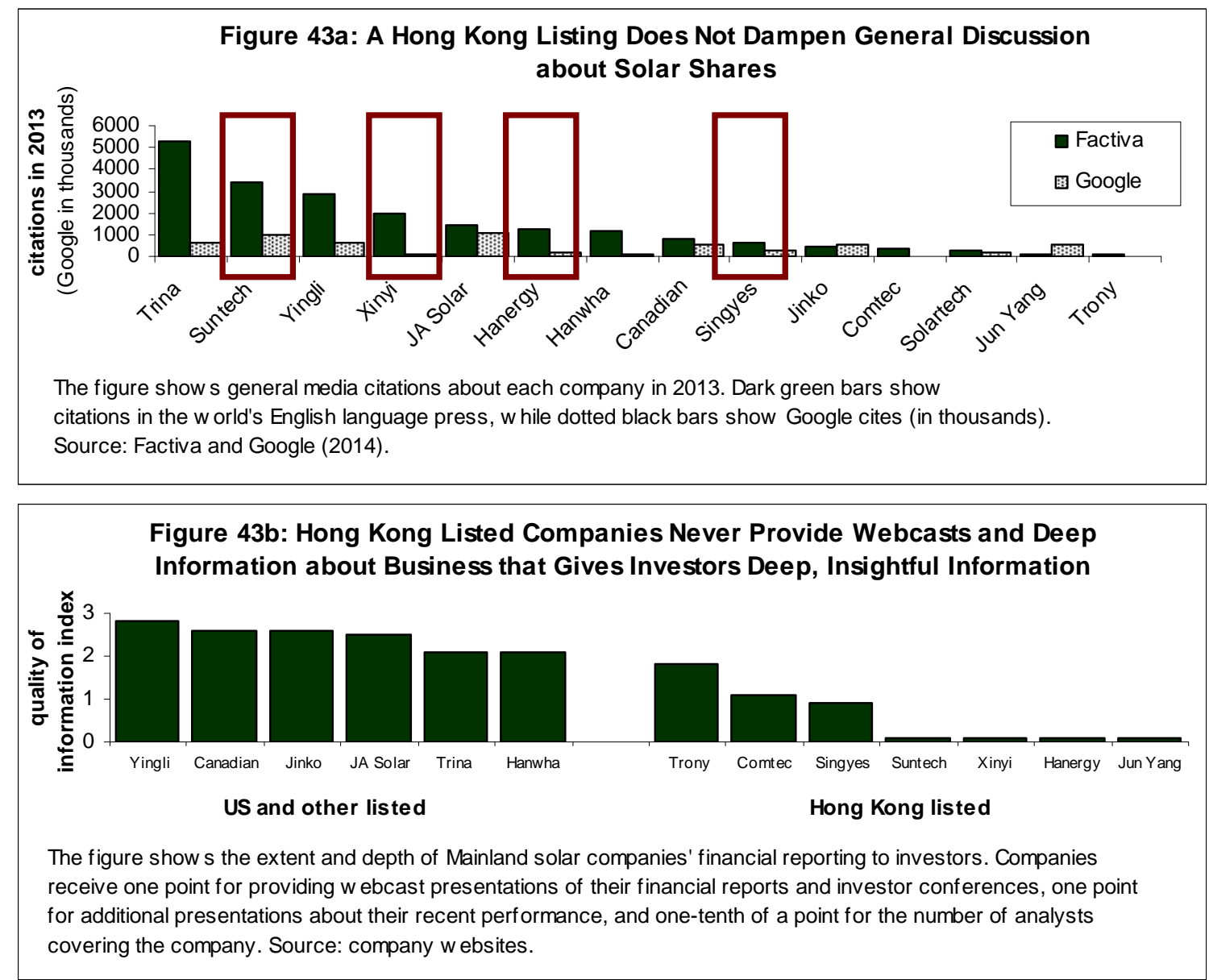

\footnotetext{
${ }^{197}$ As with previous examples, given the unscientific nature of the data used, we do not conduct more sophisticated statistical tests of similarities and differences between these two groups.

${ }^{198}$ Market practices respond to incentives given by law (and other institutions). If we observe market equilibrium practices as providing very short analytical and informational pieces, we assume market actors behave according to the incentives they face.
} 


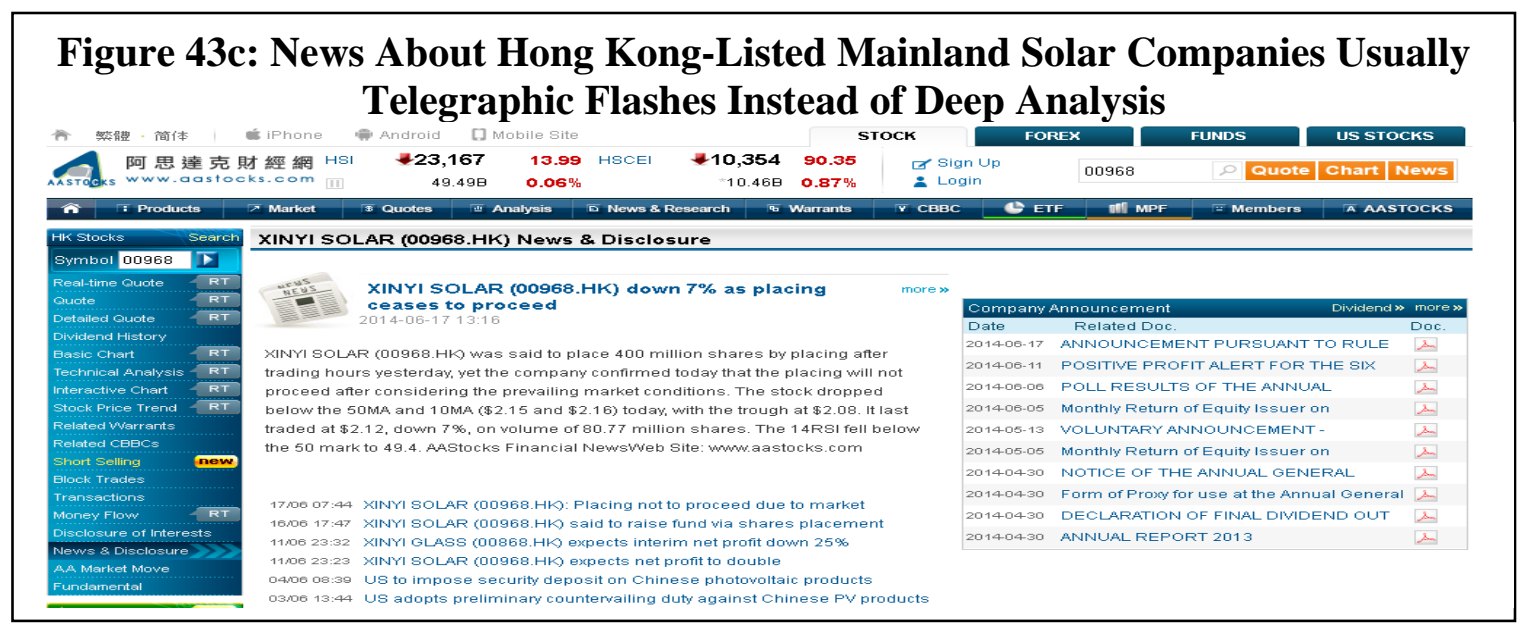

The availability of information and the geographical location of investors using an international financial centre likely go hand-in-hand. Figure 44 shows an example of an information source about securities traded in three major international financial centres and the extent of foreign interest in those shares (as proxied by web visits). As shown, Hong Kong websites cater mostly to local or Mainland investors and readers. The US and UK both have significant foreign interest in their securities. US and UK regulators and intermediaries thus have incentives to provide fuller and more accessible information to these foreign constituencies. In contrast, Hong Kong intermediaries focus on domestic investors (and to a limited extent on Mainland investors), whom they can communicate with verbally and in meetings. As a result, they do not need to produce the range of publications and analysis that UK and US intermediaries do.

Figure 44: English-Language Internet Resources for US Traders

\begin{tabular}{|c|c|c|}
\hline US & UK & Hong Kong \\
\hline Seeking Alpha & Fool UK & AA Stocks \\
\hline Foreign Visitors: 33\% & Foreign Visitors: $42 \%$ & Foreign visitors: $22 \%$ \\
\hline $\begin{array}{l}\text { Share*: India (15\%), Canada } \\
(12 \%) \text {, UK (6\%), Netherlands } \\
(4 \%)\end{array}$ & $\begin{array}{l}\text { Share*: US (36\%), India } \\
\text { (6\%), France (5\%), Canada } \\
(4 \%)\end{array}$ & $\begin{array}{l}\text { Share*: China (41\%), Macao } \\
(14 \%) \text {, Taiwan }(7 \%) \text {, US } \\
(7 \%) \text {. }\end{array}$ \\
\hline Bloomberg & Financial Times & Economic Times \\
\hline Foreign Visitors: 53\% & Foreign Visitors: $82 \%$ & Foreign visitors*: $10 \%$ \\
\hline $\begin{array}{l}\text { Share*: India (9\%), UK (8\%), } \\
\text { Canada (6\%), Japan (6\%). }\end{array}$ & $\begin{array}{l}\text { Share*: US (34\%), India } \\
\text { (8\%), Japan (4\%), France } \\
\text { (4\%). }\end{array}$ & Taiwan (50\%) \\
\hline \multicolumn{3}{|c|}{$\begin{array}{l}\text { * Share represents the share of foreign visitors calculated by dividing the proportion of website visitors } \\
\text { from a certain location by the "foreign visitors" (100\% minus the share coming from that website’s own } \\
\text { jurisdiction). } \\
\text { Source: Alexa (2014). }\end{array}$} \\
\hline \multicolumn{3}{|c|}{$\begin{array}{l}\text { Yet, the generation and intermediation of information about asset-backed securities like } \\
\text { solar company assets, liabilities and panels can particularly benefit both investors and } \\
\text { issuing companies. Figure } 45 \text { shows the superiour returns that securitising and tranching }\end{array}$} \\
\hline
\end{tabular}


assets (like solar assets) can earn because of the information thrown-off (and diversification achieved) in the process. ${ }^{199}$ Demarzo's logic (expressed in the solar context) is as follows. Imagine a financial intermediary called Bauhinia Solar Finance has invested in all kinds of solar assets -- like panels, machines and so forth. Bauhinia Solar Finance wants to sell securities in these assets. Potential investors in New York, London and Hong Kong however do not know which assets will likely pay-off. The management of Bauhinia Solar Finance however does know. Pooling these assets naturally destroys the value of this information --- they can no longer know how the whole asset pool will perform. However, investors may find pooled and tranched securities more attractive. They know diversification will protect them from Bauhinia egregiously selling them assets they know won't perform. Securitising the assets provides more liquidity -- as markets for these securities are generally more liquid than markets in share-panel revenue sharing schemes and other revenue participation schemes. Investors in these tranches should - in theory - know much more about the assets in the security than the large bundle of assets used to generate value for normal equities or bonds.

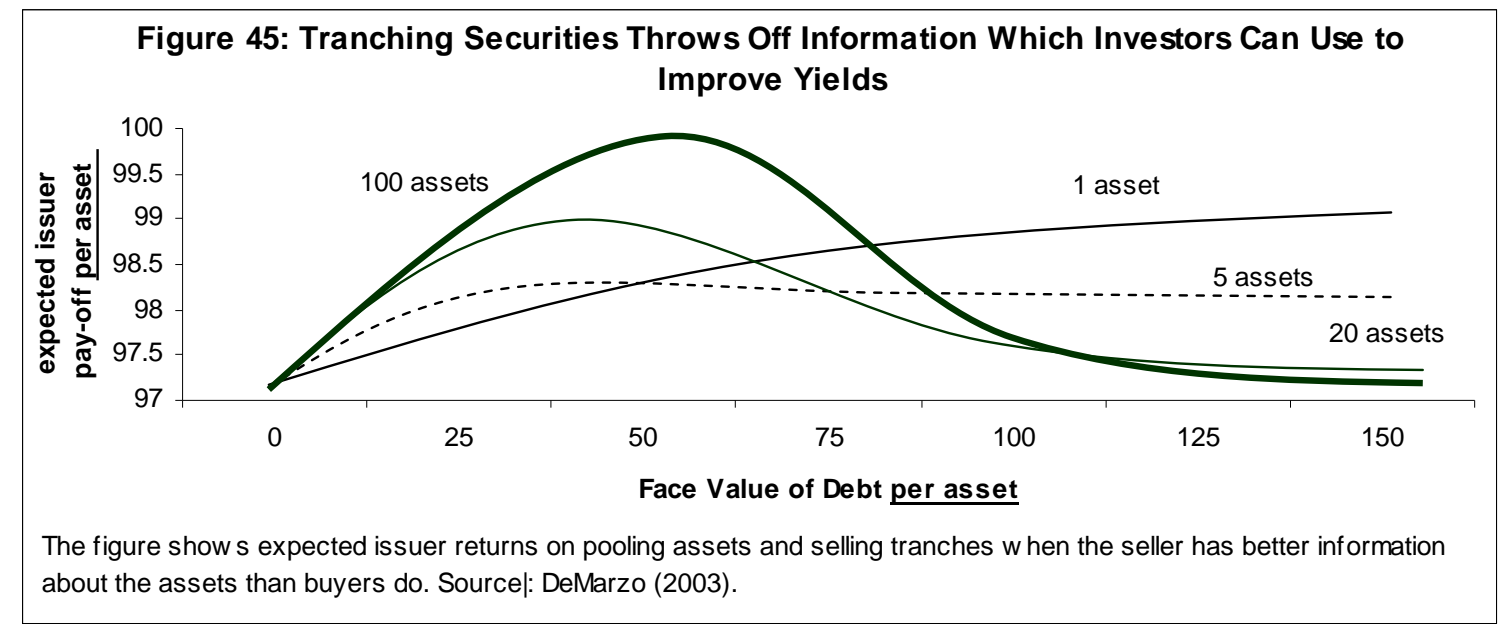

DeMarzo's model provides important insights for Hong Kong's policymakers about the way securitisation and tranching can deepen information markets for Hong Kong-traded securities of all types. In theory, securitisation should provide more information about the kinds of assets companies invest in. ${ }^{200}$ Pooling assets and tranching them requires originators, intermediaries, investors and rating agencies to take decisions about asset qualities. Yet, in practice, we observe intermediaries adding complexity into the securitisation, tranching and trading process so as to hide information about their financial transactions. ${ }^{201}$ Despite the inherently information emitting nature of selling

\footnotetext{
199 See Peter DeMarzo, The Pooling and Tranching of Securities: A Model of Informed Intermediation, 18 REV. FIN. STUD. 1, 2005.

${ }^{200}$ Asset securitisation should unbundle assets lying in a corporate portfolio and provide returns attached to those assets to specific investors. Thus, in principle, securitisation can provide more information than simple debt or equity investments. See Edward Iacobucci and Ralph Winter, Asset Securitization and Asymmetric Information, 34 J. OF LEG. STUD. 1, 2005.

${ }^{201}$ See Mei Cheng, Dan Dhaliwal and Monica Neamtiu, Banks' Asset Securitization and Information Opacity, 2008, available online.
} 
structured securitised products, financial law and custom provide intermediaries with strong incentives to structure these products so as to hide information. The mini-bond scandal happened because regulators failed to provide market actors with incentives to package in an easy-to-understand way and release the information generated by the naturally information-generating process of securitising, tranching and selling structured and securitised products.

The US provides an example of a jurisdiction realigning the incentives financial law gives to release information contained in a securitisation process. Academics like Booth have chronicled the way that inflexible financial law can retard the development of sunrise industries like solar energy. ${ }^{202}$ She militates for wide sweeping changes in financial law to accommodate "community solar" (namely financing arrangements which allow communities to invest in solar projects and receive the benefits collectively). She describes several channels for such change -- including changing state "Blue Sky" laws and relaxed SEC crowdfunding rulemaking. She also encourages increased and easier use of Regulation D (offerings to "accredited investors"), the Intrastate Exemption (which allows relaxed offering rules as long as securities are marketed only intrastate), as well as the repeal of the non-solicitation rule and an expansion of Blue Sky laws. ${ }^{203}$ At the risk of over-simplifying her argument -- the best way to encourage the development of solar financing consists of encouraging companies to provide complete and informative information, and rely on anti-fraud rules (rather than elaborate prescriptive rules) to guide and discipline market actors. Delimatsis also argues for relaxed financial rules governing the finance of sunrise industries like renewable energy. ${ }^{204}$ These two voice represent examples of a chorus of academic and professional commentators who argue that financial law needs to adapt to the needs of new technologies (like solar energy and broader investor participation in it). The solar sector best illustrates how a sunrise industry can provide incentives which encourage financial regulators to adapt “contingently" (to use our term and in contract to the "structuralist” approach).

\section{What would the final solar energy investment scheme look like?}

An information rich environment can improve the sales and liquidity of all kinds of financial services markets - including markets for solar-backed assets and liabilities. ${ }^{205}$ As we have argued, financial policy (and thus law) should encourage the generation of information which help financial service providers match solar assets and liabilities to investors' current portfolio needs. Before we can describe the kinds of legal changes needed to bring about a "better" market for sunrise industries (like solar), we need to

\footnotetext{
${ }^{202}$ See Samantha Booth, Here Comes the Sun: How Securities Regulations Cast a Shadow on the Growth of Community Solar in the United States, 61 UCLA L. REV. 760 (2014), available online.

${ }^{203}$ For Regulation D, see 17 C.F.R., at sec. 230.504-6, 2013.For the Intrastate Exemption, see 15 U.S.C. sec. 77c(a)(11), 2012, [also called the Section 3(a)(11) exemption after the original piece of legislation]. For state Blue Sky law exemptions (also known as Rule 504 exemptions), see 17 C.F.R. sec. 230.504(b)(2), 2013.

${ }^{204}$ See Panagiotis Delimatsis, Promoting Renewable Energy Through Adaptive Prudential Regulation in Financial Services, TILEC DP 2010-017, 2010, available online.

${ }^{205}$ In this section, we ignore the legal issues to focus on what an idealised solar investment service might look like. We discuss legal issues in a later section.
} 
describe what such a market would look like. Figure 46 provides an example, based on California's experience, of investment information provided by crowdfunder Mosaic. Mosaic has received about \$20 million from private investors and from the US government to develop solar-related investments worth in excess of \$100 million. ${ }^{206}$ While Mosiac currently aggregates small amounts of money for small investors, there is no reason why such a scheme can not apply on a large-scale.

\section{Figure 46: Offering Solar Investments Based on California-Based Mosaic's Experience}

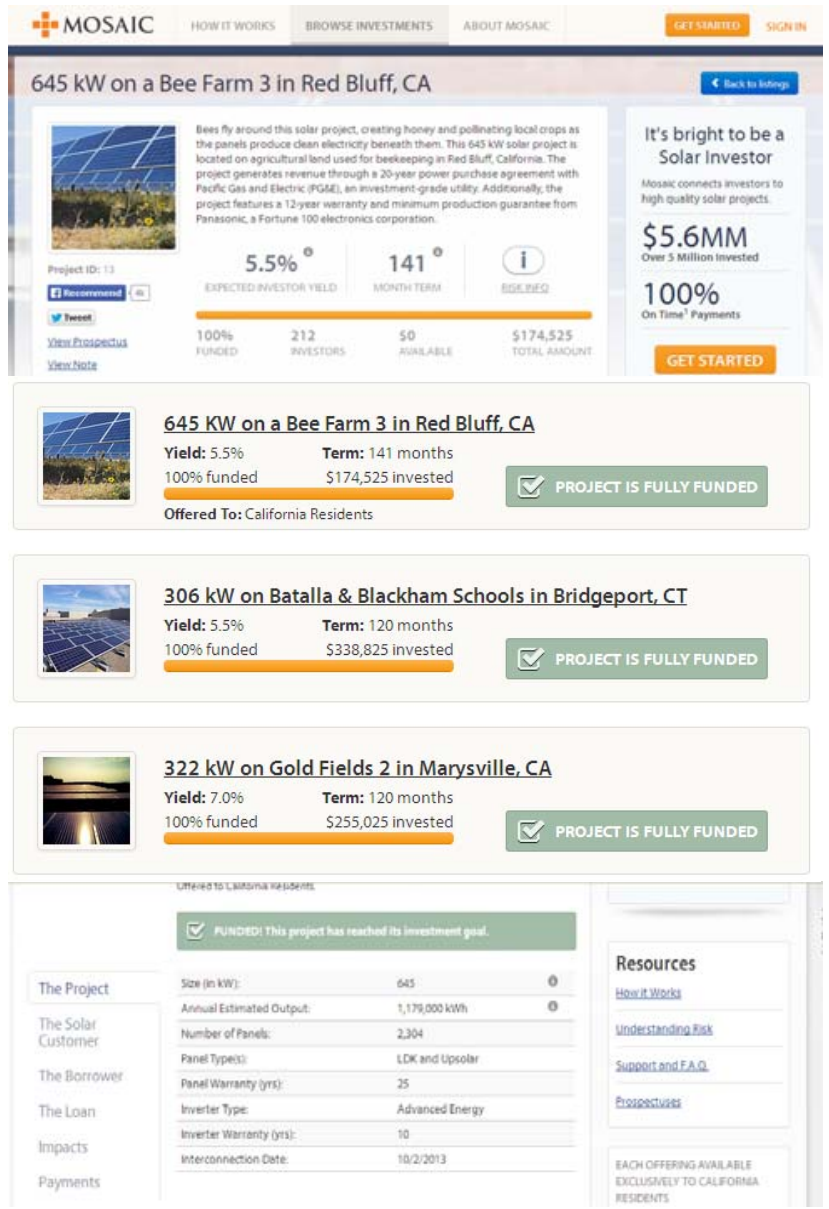

Projects listed by place, with graphics and funding status. In that way, investors can clearly see where they are investing, in which project, and which state residents are accepted. Transparently listed yields mean potential investors do not need to dig around a term sheet to find out what the true yield is. Prospectuses are available from clearly visible links.

Signing up consists of a one-click process taking the hassle out of investing for a wide range of potential investors. No need for free product give-a-ways or the other tricks that plagued Minibond offerings. Investors can see what potential yields are, terms, and how much funding has been received. Particular investments can even be excluded to particular investors (those in jurisdictions with regulations prohibiting such sales). Automatic exclusions can reduce policing time and costs.

The site provides technical information on the asset, including electricity generation capacity, number of panels, warrantee time, and so forth. No long legal language, just facts about the assets themselves. The platform also offers resources which help investors understand what they read and get more information. No trolling around a regulator's database.

Source: Mosaic (2014). We have no business or investment relationship with this company and receive no commissions or other rewards for discussing this example.

\footnotetext{
${ }^{206}$ See Andrew Herndon, Solar Mosaic’s Crowdfunding Beats Treasuries With 4.5\% Return, Bloomberg, 7 Jan, 2013, available online. See also Wendy Koch, U.S. solar projects get lift from online tool, USA Today, 17 June, 2014, available online.
} 
Tthe Mosaic example shows three attributes of market design (particularly for securitised assets) which improves the quality of financial information in that market. ${ }^{207}$ First, crowdfunding platforms like Mosaic show exactly which assets "investors" purchase and what they will be used for. ${ }^{208}$ Second, they facilitate the trade of assets rather than stocks and bonds. Investors using the Mosaic platform obtain stakes in hard assets, not opaque companies which bundle assets and liabilities together. ${ }^{209}$ Third, a solar platform like Mosaic encourages public discussion about specific assets and the development of the solar industry in general. Proof of viability also encourages market entrants - deepening the market (and thus improving the quality of markets). ${ }^{210}$ These principles emerge most clearly in crowdfunding -- yet, there is no need to confine these principles to small-scale, community investment. The development of a Mosaic-like entity in Hong Kong represents a public good which could help improve the quality of market information and participation in those markets.

As we have argued, an international financial centre's law develops “contingent” on geography and market-factors. ${ }^{211}$ The crowd-funding platforms (like Mosaic) which have developed in California show the importance of geography and focusing on market needs, instead of focusing "best practice” financial law or adopting Financial Stability Board recommendations. New technologies in California, combined with heavy-handed business regulation, have led to the crowd-funding movement which entered federal (US) and later California law. ${ }^{212}$ Financial law in the US (in particular) is redefining "who" (and more important "what”) is a broker-dealer in response to this sunrise industry. ${ }^{213}$ Indeed, most commentators argue that regulations requiring open websites and transparency serve as a sin qua non for any rulemaking in this area. ${ }^{214}$ Innovation in

\footnotetext{
${ }^{207}$ We take these three attributes from the broader policy literature. Many governments have started consultations for developing a crowdfunding policy, as crowdfunding increases participation and transparency of certain types of speculative investments. However, we want to focus on broader attractive elements of the developments in crowdsourcing policy (and law) which be applied to financial law more generally. See Kristof De Buysere, Oliver Gajda, Ronald Kleverlaan, Dan Marom, and Matthias Klaes, $A$ Framework for European Crowdfunding, 2012, available online.

${ }^{208}$ We put the word investor in quotes as many crowdfunding platforms treat investments as charitable contributions in order to circumvent securities regulations. See Edan Burkett, Crowdfunding Exemption Online Investment Crowdfunding and U.S. Secrutiies Regulation, 13 TENN. J. BUS. L. 63, 2012. Crowdfunding Exemption - Online Investment Crowdfunding and U.S. Secrutiies Regulation, A, ${ }^{209}$ Mosaic has already encouraged large solar companies to follow its example. SolarCity has announced plans to offer Mosaic-style asset-backed obligations to investors. See Christopher Martin, SolarCity Plans to Offer Asset-Backed Debt to Retail Investors, BLOOMBERG 15 JAN., 2014, available online.

${ }^{210}$ At the time of this writing, SunFunder and Crowdsun had entered the market to compete with Mosaic. Literally hundreds of start-up solar crowdfunding sites have arisen in response, including of RE-volv and Everybody Solar.

${ }^{211}$ We put the word contingent in quotes as we contrast what we call the structuralist view of financial law in international financial centres with a contingency-based view.

${ }^{212}$ We do not have space to describe the background to the law. However, we should highlight that many observers point to a café in Silicon Valley (Oakland California) as the start of the crowd-funding movements. See C. Steven Bradford, The New Federal Crowdfunding Exemption: Promise Unfulfilled, 40 Sec. Reg. L. J. 3, 2012.

${ }^{213}$ See Shekhar Darke, To Be or Not to Be a Funding Portal: Why Crowdfunding Platforms Will Become Broker-Dealers, 10 HASTINGS Bus. L.J. 183, 2014.

${ }^{214}$ Bradford provides excellent proposals for the provisions for any future crowdfunding regulation. He, like most authors writing about crowdfunding law, argues that such law must require open and plentiful
} 
California (and elsewhere where proponents of crowdfunding seek to raise funds) creates new and little-understood technologies. Crowd-funding offers the natural advantage of producing and offering extensive information about these new investments at the same time as presenting the opportunities to invest in the assets themselves. In such an information-rich environment, regulators have less need to adopt specific requirements governing the types of disclosure companies make. ${ }^{215}$ Such an information regime might help tackle the lack of transparency and other issues which have stinted the growth of Hong Kong's structured products and other securities.

Mosaic's location illustrates why Hong Kong (rather than Shanghai or Shenzhen) can become China's solar investment hub. As we discussed in a previous section, financial centres providing funds to sunrise industries tend to agglomerate in different areas than where these new sunrise industries themselves agglomerate. Figure 47 shows the location of Mosaic investors - as compared with the solar panel assets they fund. Mosaic sits in Oakland, California - close to many of its investments. Yet, other investments lump together in the US Southwest and Northeast. In general, many of the largest US contractors' headquarters - like SolarCity (in San Mateo) sit in Northern California. Yet, financing companies like Solar World (Camarillo) sit in Southern California. Funds in Southern California fund Northern California solar ventures, and visa-versa. The undisputed financial centre for solar assets has yet to be established. Yet, if history serves as a guide, such a centre will sit not-too-close and not-too-far from the solar companies themselves. ${ }^{216}$ Even if Shanghai and Shenzhen develop financial centres with superior solar financing competencies, a place will still exist in the Mainland's solar ecosystem for a Hong Kong solar investment centre. ${ }^{217}$

information disclosure. Comparing Mosaic (a crowdfunded asset-backed asset site) with MarkIt (a proprietary site providing information about asset-backed and other securities) shows how promising the development of asset-backed securities markets following the Mosaic example can be. See Steven Bradford, Crowdfunding and the Federal Securities Laws, 2012 Colum. Bus. L. Rev. 1, 2012.

${ }^{215}$ Many of these community-based funding schemes produce so much information that academic authors strain to describe what information companies must provide. For authors like Ellenoff, regulatorily required information consists of the basics like financial information. See Douglas Ellenoff, Making Crowdfunding Credible, 66 VAND. L. Rev. 19, 2013.

${ }^{216}$ Cumming and Dai show, in their study of US venture capital, that "local bias" (venture capitalists invest in companies in their own city) only under limited circumstances. See Douglas Cumming and Na Dai, Local bias in venture capital investments, 17 J. of Empir. Fin. 3, 2010.

${ }^{217}$ Studies like Florida's show that any jurisdiction developing one or more large sunrise industries will have more than enough room for several financial centres. However, his study (like many in this branch of the literature) ignores the interactions across financial centres which are required to fund sunrise industries, like solar electricity generation. In contrast, Hochberg and colleagues show how financial centres can specialize - with generalists locating in one geographical area and specialist funds in others. See Richard Florida, Startup City: The Urban Shift in Venture Capital and High Technology, available online. See also Yael Hochberg, Michael Mazzeo and Ryan McDevitt, Specialization and Competition in the Venture Capital Industry, 2011, available online. 


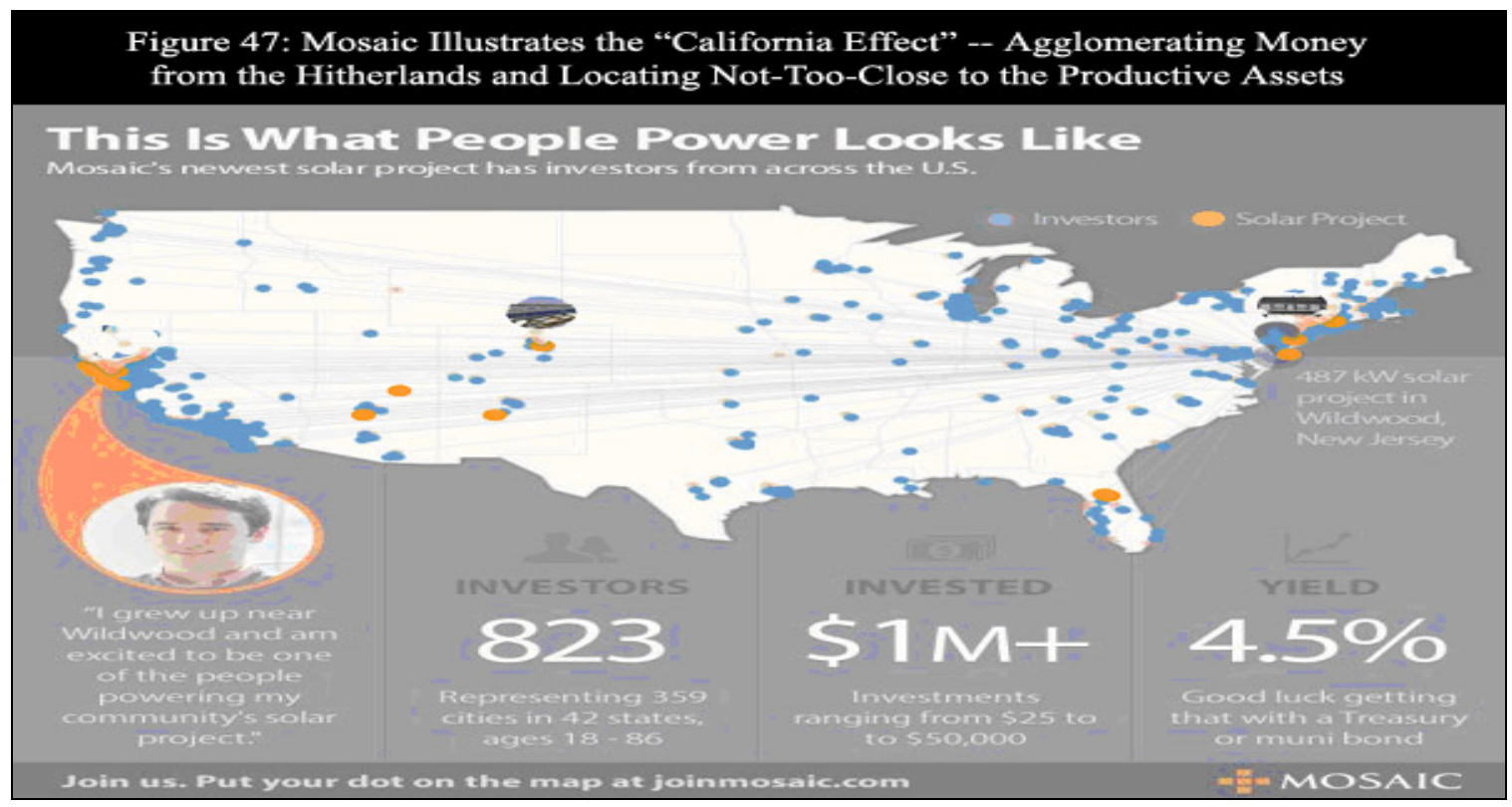

Such a regime encourages investors to learn about these products, and the broader solar market. ${ }^{218}$ Figure 48 provides several examples of online infomediaries which consolidate experts', users' and other information about specific securities (mostly equities). These services allow users (both anonymous and registered) to read and discuss analysis by other users and by mainstream media outlets. These services rely on three public goods which government policy can help put in place. First, these services receive real-time updates about changes in securities prices. If Hong Kong were to have similar services, the Hong Kong Stock Exchange would need to develop web-apps which thirdparties could query and download - preferably free of charge. Second, public policy would need to provide free infomediary services until they build a large enough mass of potential paying users to use a fee-plus-free model of information provision. ${ }^{219}$ Seeking Alpha charges for PRO users and Yahoo offers investment reports and other services for a fee. By attracting the attention of a large market, a publicly supported platform can crowd-in sellers of company information and analysis. ${ }^{20}$ Third, policy should encourage financial institutions as well as individuals to put their analysis and other information online. Far fewer research reports cover Hong Kong companies than US companies. For services like Thompson Reuters, their reports on Hong Kong companies tend to be far briefer and less insightful than those which cover US companies. Again, a body like the

\footnotetext{
${ }^{218}$ A regime which encourages the creation, dissemination and discussion of new investments does not need to run counter to an international financial centre's existing law and regulatory traditions. For example, the UK Financial Conduct Authority has proposed a range of measures aimed at promoting crowdfunding which follows the UK's and EU's existing legislation and regulatory traditions. See UK Financial Conduct Authority, The FCA's regulatory approach to crowdfunding (and similar activities), 2013, available online. ${ }^{219}$ Under free-and-fee based pricing, fees collected from those with the highest income, lowest price elasticity of demand, and most demanding customers would help pay for free services provided to the public.

${ }^{220}$ Many scholars have written about the economics of selling digital goods (like information about securities traded in Hong Kong). Selling information goods often requires versioning of free and paid content. For the bible of information marketing and economics, see Carl Shapiro and Hal Varian, INFORMATION RULES, 1998.
} 
Financial Services Development Council can encourage financial institutions to release more of their research to the public. ${ }^{221}$

\section{Figure 48: What Would Infomediary Discussion of Hong Kong-listed Solar Assets (and Liabilities) Look Like?}

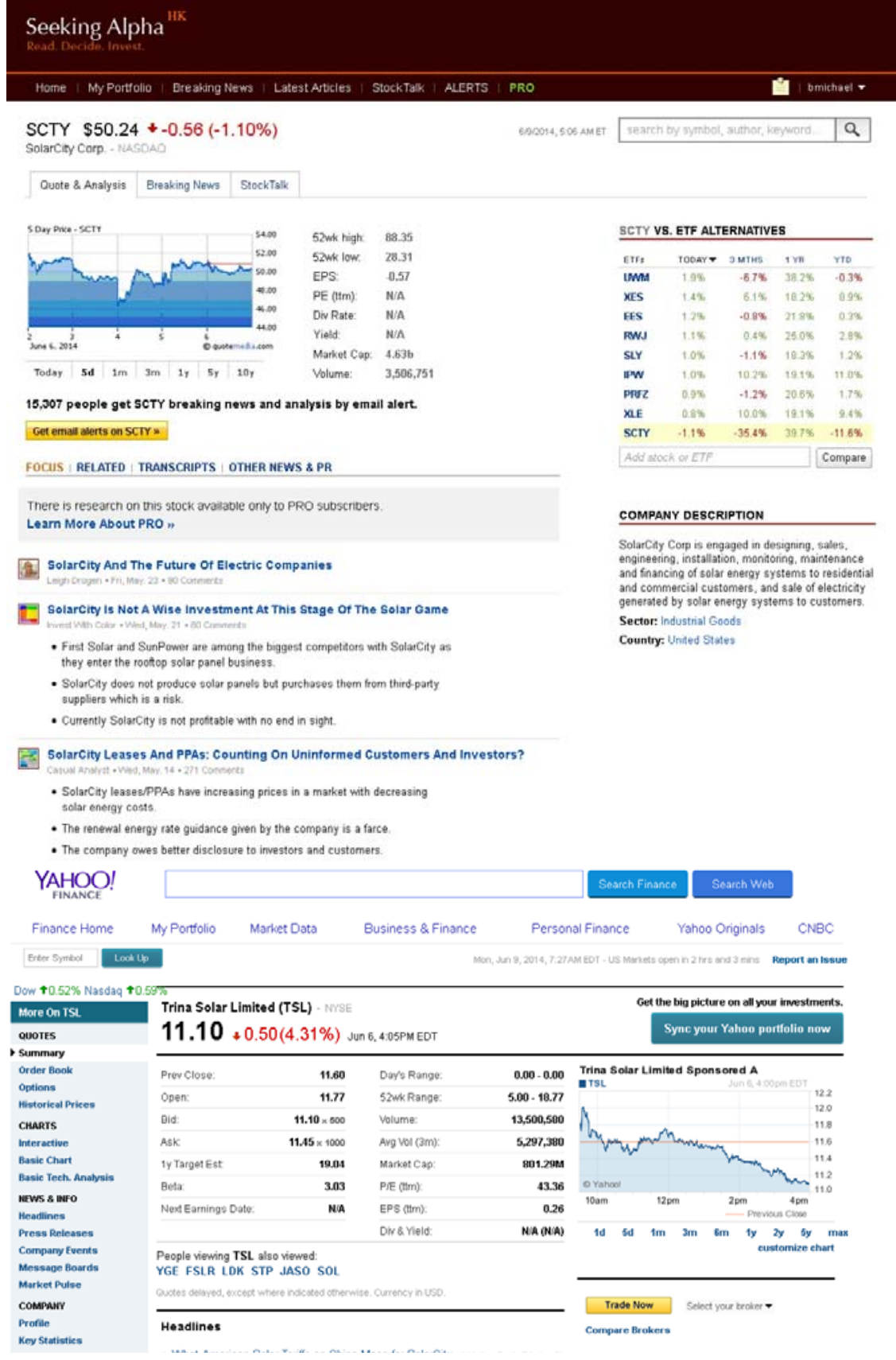

A Hong Kong franchise of the popular Seeking Alpha site could start focused on solar stocks and move out from there. With a proven business model and extensive participation, a Hong Kong affiliate could raise awareness about securities on offer across all industries.

Independent experts and even amateurs can post views about securities. Each writer has his/her own constituency, while appealing to the broadest readership. This provides for participation and a range of views. In the US's information rich environment, much of the service remains free.

Information aggregators provide investment information in easily to digest forms. Yahoo, Google, and other aggregators all provide financial news - giving information about US securities. They offer far less information about Hong Kong securities. Even retail brokers like E-Trade with the ability to trade Hong Kong shares provide relatively

${ }^{221}$ Releasing research represents the typical collective action problem. If HSBC (for example) releases analysis for free while other institutions (like Standard Chartered) do not, investors value HSBC's analysis less. By agreeing as a group to release parts of analyst reports, allow limited blogging by staff and so forth, coordination between financial institutions can help increase the market for financial information in Hong Kong. 


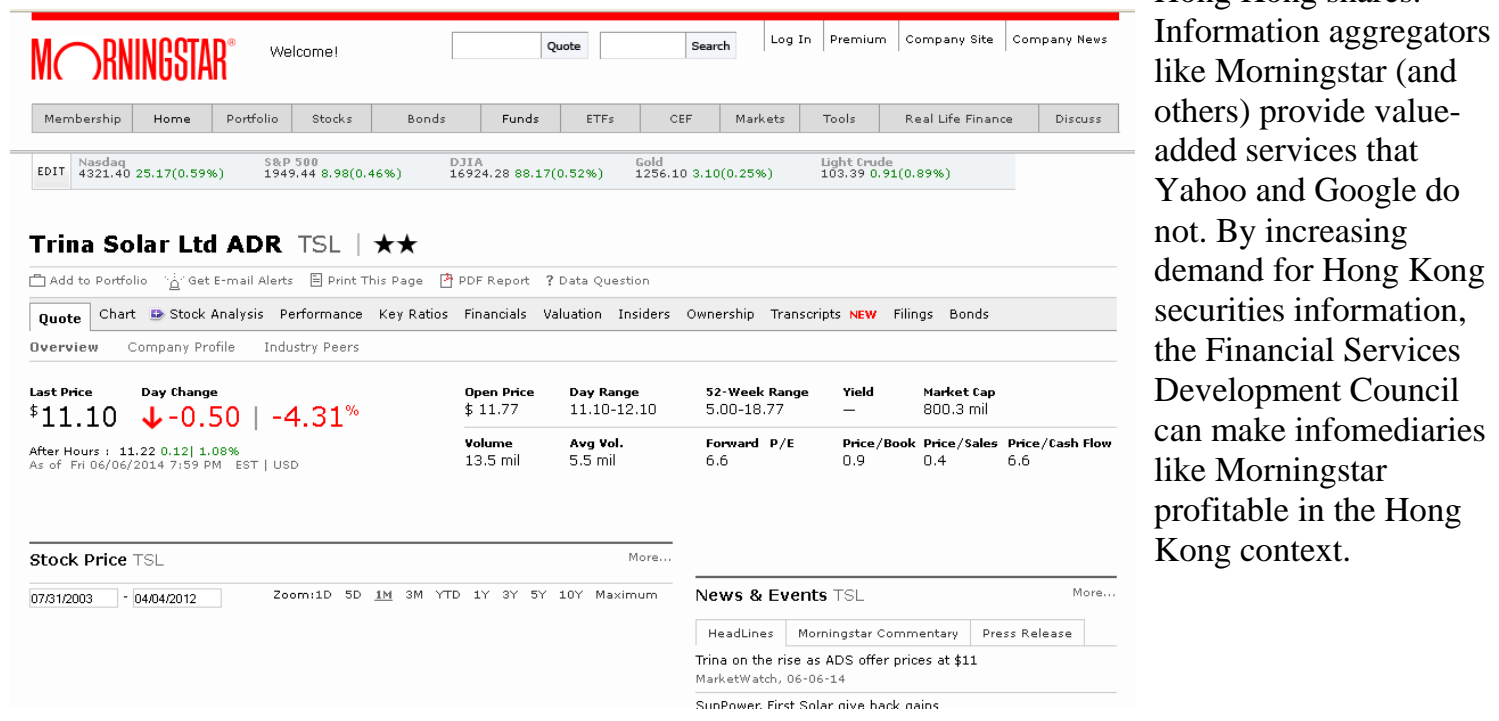

little information about Hong Kong shares. Information aggregators like Morningstar (and others) provide valueadded services that Yahoo and Google do . By increasing securities information, the Financial Services Development Council mediaries like Morningstar profitable in the Hong Kong context.

Information provision about these investments in Hong Kong - at least in the shortterm - represents a public good. Developing deeper information markets clearly requires policy intervention by the Financial Secretary. ${ }^{222}$ The market is not big enough for private companies and organisations (like the ones we have mentioned) to attract investors. As such, Hong Kong policy needs to encourage the development of these kinds of infomediaries (like Mosaic, Seeking Alpha, and so forth).

Why can't Hong Kong get there from here?

The best way to encourage the development of solar-related finance in Hong Kong consists of focusing on the needs of solar companies and their financiers. Many have already argued that the Government needs to take a pro-active role in encouraging the development of the sector. ${ }^{223}$ Yet, developing a large solar panel production cluster in Hong Kong seems unlikely. ${ }^{224}$ Hong Kong's financial institutions should focus on funding Mainland initiatives rather than (or in addition to) Hong Kong ones. Jian-ming Zheng (a property tycoon) made headlines recently by pledging about US\$530 million to

\footnotetext{
${ }^{222}$ Many think of a stock exchange and the associated organisations providing market information as the pinnacle of free-market principles in action. In fact, these institutions have traditionally emerged as selfregulating public organisations (and later as the result of public policy) to solve collective action and coordination problems. See Craig Pirrong, A Theory of Financial Exchange Organization, 43 J. of L. \& Econ. 2, 2000.

${ }^{223}$ For example. see Stephen Thompson, Why Hong Kong should be China's green-energy leader, and what we can do, SCMP 11 MAY, 2014, available online. See also Anthony Dixon and Lu Lin, Hong Kong must warm to the benefits of solar power in future energy mix, SCMP 1 APRIL, available online.

${ }^{224}$ For more on the recent failure of the Hong Kong-Shenzhen large-scale solar project after one of the largest investors (DuPont Apollo) pulled out, see Chi-fai Cheung, Sun sets on joint Hong Kong-Shenzhen solar project, SCMP 21 MAY, 2014, available online. For the success of Mainland endeavours, see Eric Ng, Solar farm taps crowd funding for 10m yuan project, SCMP 20 FEB., 2014, available online.
} 
buy Mainland solar-related assets. ${ }^{225}$ Bloomberg reports his state in Shunfeng Photovoltaic International rose more than 2,900\% -- clearly showing the profitability of investing in Mainland solar assets. ${ }^{226}$ Yet, Hong Kong securities laws have not helped investors like Zheng -- and millions of others -- make these kinds of investments.

Part of the problem revolves around Hong Kong's legal conceptions of what constitutes a security investors should want to invest in. During the recent 5-10 years, the US and UK have modernised parts of their securities law to promote the development of sunrise industries - prompting some scholars to engage in a rethink about the nature of securities themselves. ${ }^{227}$ These changes take into account new tastes in investing (such as investing directly in assets rather than in stocks and bonds which give investors only indirect access to assets and liabilities they may be interested in). These legal changes also take into account the fact that some new industries (like internet or renewable energy assets) may require new securities that pass through risks and returns more effectively than traditional stocks and bonds. ${ }^{228}$ What are some of these changes - and what can Hong Kong learn from international financial centres' experiences?

In the next section, we review several seemingly disparate pieces of legislation. DoddFrank looks different than the JOBS Act. However, both seek to increase disclosure and information about assets - a principal which not only protects investors, but (as we have shown in our discussion of solar) can increase market depth and liquidity for sunrise industry assets and liabilities. In the first part, we review changes in reporting about special purpose vehicles and collective investment companies "stuffed" with assetbacked asset securities. We show how a disclosure regime can help improve markets by giving infomediaries information. The second section talks about legal changes to/for infomediaries and funding portals. The third section talks about changes in the security of collateral placed in these company vehicles. At present, investors can not go after the assets. The fourth section talks about changes in Hong Kong's advertising regime. We argue for a special regime - modelled after the JOBS Act - promoting informational rather than demand-raising ads. The fifth section talks about how a solar industry (or any sunrise industry based on asset-backed securities) needs to improve collections on the Mainland. We describe how to improve those collections. The sixth section describes changes to credit agencies. The traditional credit agencies can help investors form

\footnotetext{
${ }^{225}$ Ehren Goossens and Benjamin Haas, Hong Kong property tycoon betting big on solar rebound, BLOOMBERG 2 APRIL, 2014, available online.

${ }^{226}$ Id.

${ }^{227}$ See Thaya Knight, Hui-wen Leo, Adrian Ohmer, A Very Quiet Revolution: A Primer on Securities Crowdfunding and Title III of the Jobs Act, Michigan Journal of Private Equity \& Venture Capital Law, Vol. 2, p. 135, Fall 2012. See also Joan Heminway, What is a Security in the Crowdfunding Era? 7 Ohio St. Entrepren. Bus. L.J. 335 (2012) University of Tennessee Legal Studies Research Paper No. 204 ${ }^{228}$ Preliminary data has already come in showing that securitisation of non-financial firm assets may provide "better" sequestration of individual risks and rewards in a company (as measured by the returns on these securities). Securities which provide investors with better isolation of risks and returns should experience higher demand - and thus higher returns as investors bid up their prices. See Michael Lemmon, Laura Xiaolei Liu, Mike Qinghao Mao, and Greg Nini, Securitization and Capital Structure in Nonfinancial Firms: An Empirical Investigation, J. OF FIN. (forthcoming), available online. See also Faten Sabry and Chudozie Okongwu, Study of the Impact of Securitization on Consumers, Investors, Financial Institutions and the Capital Markets, 2009, available online.
} 
decisions about asset-backed securities. But new forms, like crowd credit ratings, are better. The seventh section culminates in a sunrise investment promotion ordinance (SIPO). The last section describes the Financial Services Development Council's role in promoting sunrise industries. While we talk a lot about crowdfunding of asset-backed securities and other structured products, we want to focus on the principles which Hong Kong's regulators can apply across all sizes and types of investment. ${ }^{229}$

\section{Financial Law in the Service of Demand for Sunrise Industry (and Solar) Securities}

\section{Special purpose vehicles and issuers in asset-backed sunrise industry securities}

Recent changes in financial law have recognised that new technologies require new rules around the treatment of securitised assets and liabilities. Traditionally, asset-backed securities have been except from registration, as they have been sold in private placements to accredited and qualified-institutional investors. Yet, supporting our paper's thesis that law is “contingent” on investors' needs, as asset-backed securities become more useful to investors of all kinds, US law has adapted. ${ }^{230}$ The Dodd-Frank Act - and related SEC rulemaking in particular -- has put in place reforms aimed at increasing information disclosure about asset-backed securities and other types of securitised products. ${ }^{231}$ Figure 49 shows some of the provisions aimed at increasing the transparency of the asset-backed securities market in the US. ${ }^{232}$ As shown, most of these provisions encourage investors to produce information (or invest in the production of such information) about asset-backed security-related investments. ${ }^{233}$ Proposals and new rules require the disclosure of asset-level information, computer-readable loan-level information, required reporting when securities trade hands, information about repurchases, and requirements to disclose representations and warrantees. New proposals also encourage giving investors the tools they need (like waterfall simulations) showing which assets and tranches might not be paid in case the underlying assets do not pay-off.

\footnotetext{
${ }^{229}$ The convergence of new (looser) rules on advertising and participating in securities transactions and crowdfunding in the US occurred because of new information technologies (the internet) and the need to stimulate post-crisis job growth. The principles contained in the JOBS Act or CROWDFUND Act though do not necessarily need to apply only to small size transactions and other features which characterise crowdfunding.

${ }^{230}$ See Aron Zuckerman, Securitization Reform: A Coasean Cost Analysis, 1 HARV. Bus. L. ReV. 303, 2011.

${ }^{231}$ Hahn provides a competent overview of the changes. Generally speaking, readers interested in looking at specific parts of the Act related to asset-backed securities should consult section 943 and the SEC's rules related to implementing the section. See Robert Hahn, Dodd-Frank Act-Securitization-Related Final Rules, 67 Bus. LAWYER 3, 2012. See also US Congress, Dodd-Frank Wall Street Reform and Consumer

Protection Act, 124 STAT. 1376-2223, at sec. 943. See also SEC, Securities and Exchange Commission (SEC) adopted final rules to implement Section 943 of the Dodd-Frank Wall Street Reform and Consumer Protection Act (the Dodd-Frank Act) related to asset-backed securities (ABS), RELEASE Nos. 33-9175; 3463741.

${ }^{232}$ For an overview, see SEC, Asset-Backed Securities, 2014, available online.

${ }^{233}$ The US has championed increasing the production of such information in fora like the International Organization of Securities Commissions (IOSCO). The Organisation has recently promulgated a set of principles aimed at increasing asset-backed securities-related disclosures. We will illustrate how putting the IOSCO principles into action in the specific case of solar investments could help improve liquidity in Hong Kong's solar asset-backed securities markets. See IOSCO, Principles for Ongoing Disclosure of Asset Backed Securities, 2012, available online.
} 
The new proposals and rules encourage the production of information by removing the requirement to have an investment grade from a recognised credit rating agency. As we discuss below, investors may develop their own risk assessments, pay for third-party risk assessments and talk with other investors. Such requirements create markets in assetbacked securities information. $^{234}$

\section{Figure 49: Reporting on Asset-Backed Securities Can Only Deepen Demand for Solar Securities in Places Like Hong Kong}

Provision
Asset-level
Information
Disclosures
Accompanying
Ratings
Computer-readable
loan-level
information
Maintenance of
“waterfall”
programme
Lengthening
decision deadlines
Issuer review of
assets
Remove
requirements for A
rating
Allow investorsto

Allow investors to talk with other investors

Required reporting when securities trade hands

Required repurchase if breach warrantees and representations Information about repurchases

\section{Description \\ Reference}

Dodd-Frank requires the SEC to create rules governing the disclosure of asset-level information. The new rules remove a previous exemption from disclosing for certain kinds of assetbacked securities.

Ratings reports should describe the representations and warrantees made in the offering documents.

Offering institutions must report asset-level information and grouped account data in XML (eXtensible Markup Language) as an "asset data file" downloadable on the EDGAR site. Requires issuers to provide a computer program which models the security's flow of funds (or "waterfall”); helping investors analyze the offering and monitor performance. Investors should have a "reasonable" amount of time to assess the offering before the close of the offer.

Issues should review the assets underpinning an asset-backed security.

Issuers no longer need to show an "investment grade” from a ratings agency to qualify for reducing reporting requirements.

Any "shelf registered" securities (with reduced reporting requirements) must require the issuer/offerer to share investor information -- allowing investors to communicate with each other.

Known as "Exchange Act reporting", these rules a DoddFrank provision which requires asset-backed securities to report, just like other securities under the 1934 Securities Exchange Act.

Requires securitizers to buy-back securities if they made an inaccurate warrantee or representation.

Dodd-Frank s. 942

and SEC Rel. 34-

65148

$\underline{\text { SEC Rel. 33-9175 }}$

$\underline{\text { SEC Rel. 33-9117 }}$

$\underline{\text { SEC Rel. 33-9244 }}$

$\underline{\text { SEC Rel. 33-9117 }}$

$\underline{\text { SEC Rel. 33-9176 }}$

SEC Rel. 33-9245

SEC Rel. 33-9244

\section{Sec Rel. 34-63652}

$\underline{\text { SEC Rel. 33-9175 }}$

Securitizers must provide a table, reporting a security's history of fulfilled and unfulfilled repurchase requests (aggregated for all of the securitizer's asset-backed securities) if investors are required to repurchase assets.

The table provides an (over)simplified description of US asset-backed securities' disclosure-related rulemaking. See the original citation for specifics.

Source: US Securities and Exchange Commission (2014) and American Bankers Association (2012), available online.

\footnotetext{
${ }^{234}$ We do not discuss provisions aimed at reducing systemic risk (most importantly by requiring originators to retain part of the securities they package and sell).
} 
The US's new rules on asset-backed securities show the "contingent" way financial law evolves in a leading international financial centre. US regulators have focused on rules which increase investors' access to information about asset-backed assets - making markets deeper as well as safer. Traditionally, US law has exempted asset-backed security issuers from stringent information filings with the SEC, as long as these issuers maintained an investment grade rating. ${ }^{235}$ Three new developments (which we briefly described in the figure above) will encourage investors and third-parties to generate a multiplicity of reviews and assessments. First, issuers of asset-backed securities need to assess the underlying assets for any registered asset-backed security - and ensure the accuracy of statements made about those assets. ${ }^{236}$ Second, transaction documents require credit risk managers to review the underlying assets in order to obtain reducing filing paperwork conditions (a "shelf filing") with the SEC. ${ }^{237}$ Third, much of the information required to be disclosed will sit on publicly available databases -- providing the "fodder" for a range of independent assessments. ${ }^{238}$ Hong Kong law should follow the US in increasing requirements which increase the number and depth of assessments of asset-backed securities.

Hong Kong engaged in few of these reforms - making its asset-backed securities markets opaque and thus less liquid. ${ }^{239}$ In general, Hong Kong regulations govern disclosures and advertising relate to listed and unlisted structured products. ${ }^{240}$ Both pieces of regulation follow the general principle that advertising should "not be false, biased, misleading or deceptive and should include appropriate risk warnings."241 The Securities and Futures Commission (SFC) has recently concluded perfunctory work on reforming Hong Kong's structured products. ${ }^{242}$ Yet, nothing in the SFC's Guidelines and Codes comes remotely

\footnotetext{
235 The Investment Company Act of 1940 generally requires companies selling investment products to register as an "investment company." Such registration brings with it numerous regulatory requirements to register and follow certain rules. Rule 3a-7 of the Act allows asset-backed securitizers to avoid registration if they sell securities only to accredited investors, qualified institutional buyers (among other conditions). See Investment Company Act, at Rule 3a-7, available online. For an overall of the proposed changes to the rule, see also Orrick, ABS Issuers and the Rule 3a-7 Exclusion from the Investment Company Act, 2011, available online.

${ }^{236}$ SolarCity's recent offering shows the amenability of solar-backed assets to such assessments. The offering documents report the results of engineers' assessment of the underlying assets. See see Xilun Chen and Weili Chen, SolarCity LMC Series I LLC (Series 2013-1), available online.

${ }^{237}$ See Bingham, SEC Issues Advance Notice of Proposed Rulemaking on Treatment of Asset-Backed Issuers Under Rule 3a-7 and Section 3(c)(5) of the Investment Company Act, 2011, available online.

${ }^{238}$ See PwC, FSR Insights: 20 questions about the status of Regulation AB 2.0, FSR INSIGHTS, 2014, available online.

${ }^{239}$ Many academics have focused on inadequate disclosure as the Achilles-heel of Hong Kong's regulations governing asset-backed securities and securitised products. See Will Shen, When Complexity Impairs Disclosure - A Critique of SFC's Proposal to Strengthen the Disclosure Regime after the Lehman Minibonds Incident in Hong Kong, 23 EURO. BUS. L. REV. 6, 2012.

${ }^{240}$ The relevant regulations sit in two pieces of regulation -- SFC Handbook for Unit Trusts and Mutual Funds, Investment-Linked Assurance Schemes and Unlisted Structured Investment Products and the Guidelines on Marketing Materials for Listed Structured Products,

${ }^{241}$ See SFC, Guidelines on marketing materials for listed structured products, available online.

${ }^{242}$ For a review, see Morrison \& Foerster, HK SFC's New Regime on Unlisted Structured Investment Products, 1 MORRISON \& FoERSTER NEW BulLETIN 10, 2010, available online.
} 
close to imposing the same kinds of disclosure US law does. ${ }^{243}$ Hong Kong regulators have seemed relatively content to follow the "structuralist" approach to reform - by adopting Financial Stability Board recommendations - rather than make regulations "contingent" on market needs. ${ }^{244}$

Imagine if Hong Kong had a US-style disclosure regime governing its asset-backed securities? Figure 50 shows a hypothetical screen shot from a database (infomediary) presenting information about an investment in the solar-backed assets we described in the previous section. The screenshot shows most of the information required by the US rulemaking we described previously. If Hong Kong adopted US-like regulations, investors would know which assets they purchase, latest trades, reviews from other investors and other information. Without explicit SFC mandates to provide such information, the information markets needed to develop Hong Kong's markets for sunrise industry securitised products will never develop.

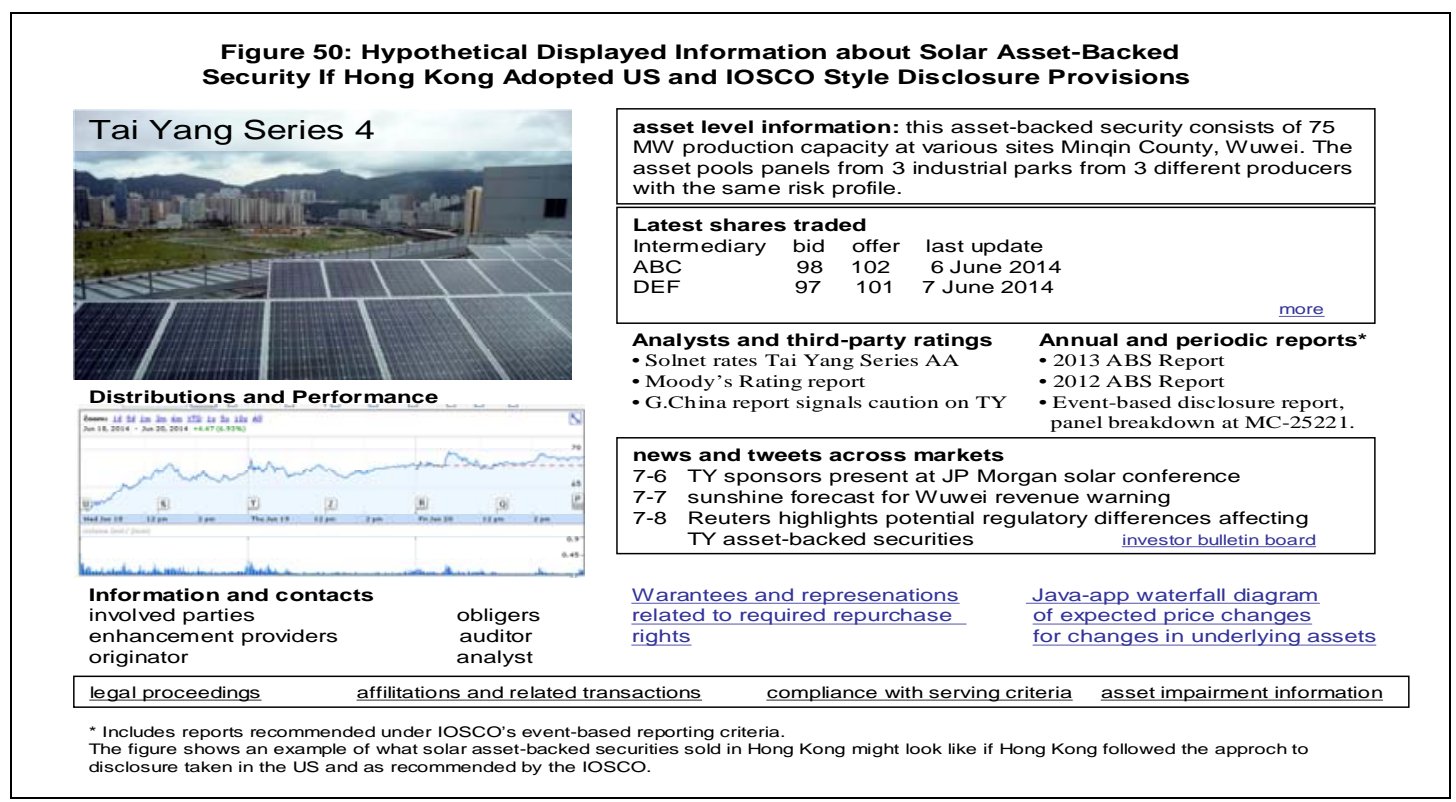

The US experience teaching us three things about the way Hong Kong's financial law can develop "contingent" to the needs of sunrise industries. First, legal change which makes for a first-tier international financial centre may not occur explicitly because policymakers want to develop sunrise industries. US lawmakers focused mostly on investor protection which adopting the relevant Dodd-Frank Act and relevant SEC rules. Yet, most analysts understood the need to change the entire trajectory of the development

\footnotetext{
${ }^{243}$ For a general review of recent rulemaking, see Linklaters, Reform of Structured Products Marketing Regime, 2011, available online. For a highly approachable review of Hong Kong's structured products disclosure requirements, see Godric Chan, Richard Mazzochi, and Urszula McCormack, Anatomy of a structured product sale in Hong Kong - are you missing anything?, KING \& WOOD MALLESONS ALERT, 2012, available online.

${ }^{244}$ For a review of Hong Kong's work on these standards, see FSB, 2013 IMN Survey of National Progress in the Implementation of G20/FSB Recommendations, 2013, available online.
} 
of US financial law -- based on new tastes and technologies. ${ }^{245}$ The Act provided securities market actors a much-needed impetus to adopt new information technologies and focus on retail investors. ${ }^{246}$ Second, Hong Kong regulators have failed to adjust regulations governing securitisation because they mistakenly see Hong Kong citizens as their constituents. As we argued in this paper, an international financial centre matches investors from outside Hong Kong (US and EU) with investments also outside Hong Kong (on the Mainland). "Importing” some of the Dodd-Frank Act (and JOBS Act) reforms would help ensure Hong Kong's regulations cover investors who have already expressed preferences for such regulation. ${ }^{247}$ Third, legal provisions requiring increased disclosure would be useless without legal changes allowing infomediaries to collect and share such information. Rules need to encourage third-parties like broker-dealers to solicit interest based on investors’ needs rather than simply promising high-yields. ${ }^{248}$ Intermediaries determine the quality, quantity and user-friendliness of information about asset-backed and other types of securities. ${ }^{249}$

\section{Infomediaries and funding portals for sunrise industries}

A vibrant market for solar asset-backed securities can develop only when law develops around investors' needs - and particularly around providing information. We previously provided the example of Mosaic Solar, showing how more information can help improve the depth and liquidity of asset-backed and securitised products markets. ${ }^{250}$ The changes

\footnotetext{
${ }^{245}$ Some have argued that Dodd-Frank represents a "paradigm shift" in the way of thinking about financial regulation. See Ronald Borod, Did Dodd-Frank Hit or Miss the Securitization Bull's Eye?, 38 WTE 3, 2012, available online.

${ }^{246}$ A Marxist might Dodd-Frank as the legislative response to dialectical forces militating for change in the US's "economic superstructure." The rest of us might just argue that the crisis provided a much-needed excuse to modernise the US's financial regulation. For a discussion, see David VanHoose, Systemic Risks and Macroprudential Bank Regulation: A Critical Appraisal, NFI PB 2011-PB-04, 2011, available online. For a more technocractic discussion of the technological aspects involved, see Rumman Iqbal and Rohit Sadhu, The Dodd-Frank Act: Impact on Derivatives Technology Infrastructure, WIPRO WP, available online.

${ }^{247}$ In other words, investors in the US (and increasingly EU) have already voted for Dodd-Frank and JOBS Act reforms -- showing their desire for these reforms. As Hong Kong broker-dealers accommodate these groups of investors, why not give them the rules they already said they want in other political arenas? While most academics criticize the way Dodd-Frank acts on those political preference, even the most strident academics do not dispute the Act's desired goals. See John Coffee, The Political Economy of Dodd-Frank: Why Financial Reform Tends to be Frustrated and Systemic Risk Perpetuated, 97 CoRnell L. REV. 1019, 2012.

${ }^{248}$ Some scholars have claimed at Dodd-Frank represents an attempt to achieve broader public policy objectives. Putting investors back in touch with the companies (and assets) they fund certainly qualifies as a public policy objective. See David Lynn, The Dodd-Frank Act's Specialized Corporate Disclosure: Using the Securities Laws to Address Public Policy Issues, 6 J. Bus. \& TECH. L. 327, 2011. Dodd-Frank Act's Specialized Corporate Disclosure: Using the Securities Laws to Address Public Policy Issues, The; $\mathrm{M}$.

${ }^{249}$ For this "epistemological" study of the way intermediaries shape investors' information set, see Henry Hu, Too Complex to Depict - Innovation, Pure Information, and the SEC Disclosure Paradigm, 90 TEX. L. REV. 1601, 2012.

${ }^{250}$ Offering memoranda usually do not make for gripping reading. However, Mosaic Solar's highlights all the major issues involved in the sale of securitised solar assets. The offering document also shows how the
} 
mostly likely to give impetus to the US's solar asset-backed securities markets do not come from Dodd-Frank or SEC rules on securitisation. They come from crowdfunding legislation. Such legal changes - with their view toward information-sharing and easing restrictions on participating in all kinds of securitisation transactions -- will likely affect securitisations in sunrise industries at all levels. ${ }^{251}$

The US CROWDFUND Act represents the first step toward creating the legal framework for transparent, wide-spread participation in the US's sunrise industries' asset-backed securities -like those offered by Mosaic Solar. ${ }^{252}$ Provisions in a part of the Act - known individually as the CROWDFUND Act - regulate many newly established crowdfunders. ${ }^{253}$ Figure 51 summarises some of the key provisions of the Act, and related rulemaking by the SEC and FINRA. ${ }^{254}$ While the provisions target small-scale investors - the Act's principles extend across the entire financial market.

\section{Figure 51: New Provisions Governing US CROWDFUND companies}

a) investments must be less than $\$ 1$ million

b) limits on investment depend on investors' income

c) regulates "funding portals" as quasi broker-dealers

d) register with a self-regulating organisation

e) "health warnings" to potential investors

f) background checks on directors

g) requires "all or nothing" offers

h) requires intermediation through portal or broker (no direct sales)

i) three tier financial reporting (100k or less is income tax statements, $100-500 \mathrm{k}$ is financial statements and $500 \mathrm{k}+$ is audited financial statements).

While US lawmakers have laid the foundations for developing online asset-backed securities markets, the SFC has taken pains to remind potential crowdfunders about the

US puts into practice many of the principles we have described. See Mosaic, Offering Memorandum: Solar Mosaic, Inc. \$294,790 Solar Power Notes, 2013, available online.

${ }^{251}$ Several authors have commented on the way the legislation we describe in this section represents a paradigm shift in the way lawmakers and regulators think about financial regulation. Like with any change, several authors express scepticism about the fit of the law in existing corpus of financial law and its likely impact. Hemingway and Hoffman question the legal fit and impacts, whereas Wenzell questions the economic impacts. See Joan Heminway and Shelden Hoffman, Proceed at Your Peril: Crowdfunding and the Securities Act of 1933, 78 TENN. L. ReV. 879, 2011. See also Tom Wentzell, The JOBS Act: Effects on Capital Market Competition in Both Public and Private Markets, 10 U. OF St. THOMAs L. J. 3, 2013.

${ }^{252}$ As part of the 2012 Jumpstart Our Business Startups (JOBS) Act, the Capital Raising Online While Deterring Fraud and Unethical Non-Disclosure (CROWDFUND) Act focuses specifically on activities the reader would identify with crowdfunding. We keep our discussion of the JOBS Act and Title III of that Act (known as the CROWDFUND Act) relatively short. See Peter Sumners, Article IV: Crowdfunding America's Small Businesses After the JOBS Act of 2012, 32 REV. BANKING \& FIN. L. 38, 2012.

${ }^{253}$ For an overview, see Michael Zuppone, Demystifying the Recently Enacted Crowdfunding and Private Offering Reforms: Opportunities for Issuers and Investors, available online.

${ }^{254}$ For a overview, see Noam Noked, Jobs Act Title III Crowdfunding Moves Closer To Reality, HLS FCGFR DEC. 6, 2013, available online. 
illegality of offering securities in Hong Kong under a crowdfunding scheme. ${ }^{255}$ Crowdfunded solar (and other sunrise industry) asset sales require three things in Hong KOng. First, solar-asset websites and offerers - whether in general or in a crowdfunded scheme - must be licensed and offer SFC-authorised securities. ${ }^{256}$ Second, advertisements themselves must follow SFC regulations and offerers must provide for a prospectus. ${ }^{257}$ Third, platforms (like Mosaic) operated in Hong Kong would probably breach provisions related to the offer of automated trading services and existence as a recognized exchange company. ${ }^{258}$ Some types of advertisements could be exempted under Hong Kong's “qualified investors” provisions. However, the other points still apply. $^{259}$ Hong Kong law does not allow for many of the provisions already adopted in the US - making Hong Kong an unlikely jurisdiction for the creation and trade of sunrise industry asset-backed securities and other securitised products. ${ }^{260}$

What can Hong Kong do to put in place platforms (like Mosaic)? Figure 52 provides a "for dummies" version of the relevant provisions governing the authorisation of an automated trading service and recognized exchange company like a Hong Kong version of Mosaic Solar. ${ }^{261}$ In both cases (allowing an "automated trading service" or "recognized exchange company"), the Securities and Futures Commission has the authority to authorise a company like Mosaic Solar to operate in Hong Kong. ${ }^{262}$ The Commission has published guidelines for regulating automated trading services. These principles-based rules require providers to have sufficient financial resources, engage in risk management, ensure their own operational integrity and fitness to operate an automated trading service. ${ }^{263}$ The Guidelines also require that providers keep records,

\footnotetext{
255 See SFC, Notice on Potential Regulations Applicable to, and Risks of, Crowd-funding Activities, 7 May 2014, available online.

${ }^{256}$ Securities and Futures Ordinance at sec. 114 -115 and Schedule 5.

${ }^{257}$ For the requirement that only authorised securities are allowed to be advertised, see Securities and Futures Ordinance, at sec. 103. For prospectus requirements, and in case of an issue by a company incorporated in Hong Kong, see Companies Ordinance (provisions on winding up and other miscellaneous provisions), at sec. 38, 38B and 38D. For a company incorporated outside Hong Kong, Companies Ordinance at sec. 342 and 342C.

258 Securities and Futures Ordinance, sec. 19 and 95.

${ }^{259}$ Aspiring solar-backed securities mongers seem highly unlikely to succeed without going through the same kinds of authorisation process as the large banks and broker-dealers. Hong Kong -- like the US -exempts advertisements and sales materials pitched only to professional investors. However, offers still need the appropriate SFC licenses. See Securities and Futures Ordinance, CAP. 571, at sec. 103.

${ }^{260}$ Even the discourse about crowdfunding these kinds of investments in Hong Kong starkly differs from the excited and optimistic tone of the US. The SCMP's Howard Winn has penned a number of hopeful articles about the sector -- noting general malaise in the crowdfunding space. For example, see Howard Winn, Hong Kong crowd funding site looking for momentum, SCMP 13 MAR., 2014, available online.

${ }^{261}$ We provide this description of the reader uninterested in the technicalities of the Ordinance and thus unlikely to rely on our paraphrase of the Ordinance. To take one example, the original refers to the "Commission” which we paraphrase as "SFC." Even a cursory reading will see we make many elisions like this. The reader should read our paraphrase side-by-side with the original to make sure some items have not been 'lost in translation.'

${ }^{262}$ Sec. 95(2) of the Securities and Futures Ordinance provides the authority to authorise a automated trading service, while sec. 19(2) allows the Commission to authorise an exchange company.

263 See SFC, Guidelines for the Regulation of Automated Trading Services, at Standard 1-3, available online.
} 
conduct their business in a transparent manner, engage in surveillance and issue reports. $^{264}$

\section{Figure 52: “For Dummies” Description of Securities and Futures Ordinance Provisions Allowing for a Hong Kong Version of Mosaic Solar}

(see disclaimer at bottom)

\section{Exchange companies}

1) No person shall operate a stock market (platform for buying and selling securities) unless the person is a recognised exchange company (among other criteria),

2) the SFC can recognise a person as a recognised exchange company if such recognition serves the public interest or helps regulate securities markets,

3) the SFC can change or amend its recognition (in consultation with the Financial Secretary) as it sees fit,

4) such a change occurs when the SFC says it occurs (as defined in a notice),

5) any person operating a stock market can be punished with fines and/or jail time,

6) when the SFC recognises a "recognised exchange company", such recognition shall appear in the (government) Gazette,

7) when the SFC does not want to recognise an exchange company, the SFC shall listen to the arguments of an aspiring "recognised exchange company" before rejecting the application for recognition,

8) the SFC shall inform the aspiring "recognised exchange company" who failed to obtain recognition about the reasons for its refusal,

9) providing automated trading services for the operation of a futures market does not constitute operating a stock market (and thus require recognition as an exchange company),

10) a "stock market" is a stock market (as defined in the Ordinance).

\section{Autorization for providing automated trading services}

1) Only authorised persons can provide automated trading services,

2) the SFC can authorise a person to provide these services as it likes,

3) when the SFC grants such authorisation, it shall announce the authorisation in the Gazette,

4) the SFC must listen to the arguments of a person applying for authorisation to provide automated trading services before refusing them,

5) the SFC should give reasons for refusing to authorise an automated trading services provider,

6) the SFC shall publish in the Gazette procedures, principles and standards for applying as an automated trading services provider,

7) such guidelines do not have legal force,

8) providers shall offer automated trading services to Hong Kong persons,

9) a person shall not technically be offering automated trading services if that person has and is providing financial services to the offeree.

Disclaimer: our brief (and possibly glib) simplification of the Securities and Futures Ordinance provisions highlighted omits several elements from each point and in several cases only roughly describes the article in the section. Please see the original for the exact wording and meaning. We label our description as "for Dummies" because the summary does not remain faithful to the content of the article in several cases.

${ }^{264} I d$ at Standard 4-7. 
The US provides examples of how such portals could be regulated. Under the JOBS Act, the Act defines a "funding portal" as "any person acting as an intermediary in a transaction involving the offer or sale of securities for the account of others." ${ }^{265}$ Funding portals need not register as a broker-dealers as long as they remain subject to SEC rulemaking, hold membership in a national securities association and follow other rules set down by the SEC. ${ }^{266}$ The Act limits them by requiring that they do not offer investment advice or recommendations, actually offer or solicit interest in the securities shown on their website, pay agents commissions for helping to sell securities displayed on the site, hold/manage investors funds, or other activities the SEC prohibit. ${ }^{267}$ The effect of such legislation consists of creating a two-track regulatory structure -- with regulatory easement for sunrise industries.

SEC rulemaking adds clarity to several JOBS Act provisions -- again mostly providing extensive and pro-active rules of encouraging the production and dissemination of information. ${ }^{268}$ The extensive list of information which funding portals must put in the public domain clearly aim at deepening information markets as much as the financial markets they underpin. These include 21 pieces of information -- including a description of the issuer's ownership and capital structure, financial condition, and disclosure of the amount of compensation paid to the intermediary for conducting the offering (among other factors). Interestingly, the US Financial Industry Regulatory Authority (FINRA) has proposed regulations for funding portals which one would expect of a self-regulating body - such as requirements to register, face disciplinary sanctions and so forth. ${ }^{269}$ FINRA rules allow the FINRA to post information given by funder portals. Increasingly the availability of public information clearly represents a goal of FINRA policy. Clearly, these regulations aim to solve a collective action problem by mandating information disclosure, thereby deepening US sunrise industry financial markets. ${ }^{270}$

\section{Requiring such a high degree of disclosure in Hong Kong could significantly add transparency (and thus interest) in asset-backed securities marketed in the city. ${ }^{271}$}

\footnotetext{
265 Jumpstart Our Business Startups Act, at sec. 304(b). For an overview, see Reid Godbolt, SEC Proposes Crowdfunding Rules for Issuers and Funding Portals, 2014, available online.

266 Jumpstart Our Business Startups Act, at 304(a).

${ }^{267}$ Id at 304(b)(A-E).

${ }^{268}$ See SEC, Crowdfunding, FILE No. S7-09-13, 2014, available online. For a more digestable version, see Michael Zuppone, SEC Proposes Regulation to Implement JOBS Act Crowdfunding Offering Provisions, available online.

269 See FINRA, Jumpstart Our Business Startups (JOBS) Act: FINRA Requests Comment on Proposed Funding Portal Rules and Related Forms, Regulatory Notice 13-34, 2013, available online. See also FINRA, Appendix A: Funding Portal Rules, available online.

${ }^{270}$ A number of commentators rightly critique the SEC rules for the wrong reason. These authors argue for relaxed information requirements because these provisions' steep compliance costs. One estimate places the cost of raising $\$ 100,000$ under these rules at about $\$ 40,000$. Critiques about their cost ignore the large social value placed on information disclosure. See Rutheford Campbell, Proposed Crowdfunding Regulations Under the Jobs Act: Please, SEC, Revise Your Proposed Regulations in Order to Promote Small Business Capital Formation, available online.

${ }^{271}$ In a recent study, Friewald and co-authors find that increased reporting of structured products (on the TRACE database) has corresponded to increased market liquidity and depth. See Nils Friewald, Rainer
} 
Some of these information items required under the new US rules already appear in Hong Kong prospectuses and other information. Yet, not all infomediaries have the same objectives -- and thus regulators should not treat them equally. Heminway broadly characterizes these infomediaries as distributional (like Sunfunder), informational (like most) and collectivizing intermediaries (like Mosaic). ${ }^{272}$ Clearly, the SEC and Finra (or their Hong Kong equivalent in the SFC) should not regulate informational sites which do not take money the same way they regulate aggregators. Moreover, as Schwartz notes, the CROWDFUND Act basically has the effect of converting debt and asset-backed into equity-like securities. ${ }^{273}$ Paraphrasing his argument, the Act imposes information reporting and other requirements on crowdfunded debt and asset-backed securities making them look, feel and act like equity. Regulation can have the effect of making non-equities look, feel and trade like equity -- increasing Hong Kong's market depth and liquidity and popularity.

Yet, Hong Kong should not slavish follow the US's lead. Figure 53 shows the major issues raised in the US's infomediary and funding portal regulations, and Hong Kong's preferred response. Most importantly in the figure, US regulations do not allow for the trade of asset-backed securities under the JOBS and CROWDFUNDING Acts' rules. ${ }^{274}$ We previously argued the US's differential treatment of crowdfunding and asset-backed securities reflects history, more than practical necessity. ${ }^{275}$ No a priori reason exists to exclude asset-backed securities from the regime we advocate - a regime encouraging Mosiac-like reporting and user-friendly investment analysis.

\section{Figure 53: How Should Provisions in Hong Kong Relate to Changes Happening in the US?}

\begin{tabular}{|c|c|c|}
\hline Issue & US & Hong Kong (preferred)* \\
\hline $\begin{array}{l}\text { nationality of firms taking } \\
\text { part }\end{array}$ & US-only & anyone \\
\hline $\begin{array}{l}\text { allow already registered } \\
\text { companies }\end{array}$ & already registered only & allow anyone \\
\hline adverts & not allowed & should be allowed \\
\hline commissions & not allowed & should be allowed \\
\hline secondary sales & only back to issuer & anyone \\
\hline anti-dilution (tag-along) & doesn't have & should have \\
\hline $\begin{array}{l}21 \text { pieces of information } \\
\text { put in the public domain }\end{array}$ & yes & also should have \\
\hline
\end{tabular}

Jankowitsch, and Marti Subrahmanyam, To Disclose or not to Disclose: Transparency and Liquidity in the Structured Product Market, 2013, available online.

${ }^{272}$ See Joan Heminway, The New Intermediary on the Block: Funding Portals under the CROWDFUND Act, 13 UC Davis Bus. L. J. 1, 2013.

${ }^{273}$ See Andrew Schwartz, Crowdfunding Securities, 88 Notre DAme L. Rev. Vol. 1, 2013.

${ }^{274}$ See Orrick, Jumpstart Our Business Startups (“JOBS”) Act Eases Restrictions on Rule 144A and Private Offerings - ABS Considerations, 2012, available online.

${ }^{275}$ As Orrick notes, the Dodd-Frank Act (with its focus on financial system risk) contains a punitive approach to asset-backed securities' regulation. The JOBS Act, in contrast, focuses on promoting job growth in a recessionary environment. 
asset-backed securities allowed?

risk-retention

The figure shows major issues in the US's asset-backed securities and crowdfunding law and provides suggestions as to how Hong Kong regulators should deal with these same issues.

* Hong Kong represents authors' recommendations.

Source: US based on JOBS Act and SEC regulations.

Several other areas should differentiate Hong Kong’s sunrise industries financial industries financial regulation from the US JOBS Act predecessor. US law does not allow for anti-dilution (tag-along) rights -- discouraging future investors. ${ }^{276}$ Clearly, this represents an oversight which Hong Kong regulators can relatively easily address at home. US-based asset-backed securitisation schemes controversially require issuers (originators) to retain some of the risk in the securitised assets they sell. ${ }^{277}$ Such risk retention requirements will likely make the US markets less attractive, increasing Hong Kong's lustre as a securitisation centre. ${ }^{278}$ Hong Kong lawmakers need not -- and probably will not -- adopt similar risk-retention measures at home. ${ }^{279}$ The US only allows US firms to take part in the JOBS Act -- and its incentives. Clearly, faults with US securitisation rules provide a market opportunity for Hong Kong. ${ }^{280}$

\section{Making advertising easier and more informative}

Advertising represents one of the key ways of informing investors about the most productive opportunities for deploying their capital - particularly in sunrise industries. Regulators and their advisors usually focus on "persuasive" advertising - advertising which seeks to encourage investors to buy investments they normally would not in the absence of such advertising. ${ }^{281}$ Statutorily-defined objectives focusing on investor protection usually guide regulators' focus on persuasive advertising. ${ }^{282}$ Yet,

\footnotetext{
${ }^{276}$ See John Wroldsen, The Social Network and the Crowdfund Act: Zuckerberg, Saverin, and Venture Capitalists' Dilution of the Crowd, 15 VAnDERBILT J. of ENT. \& TECH. L. 3, 2013.

${ }^{277}$ See KPMG, Regulators Revise Proposed Risk Retention Rules for Asset-Backed Securitizations, 13 Defining Issues 46, 2013, available online.

${ }^{278}$ We ignore the issue of whether such rules will promote financial stability -- as the academic literature still has not reached a conclusion. The main point remains -- US risk retention requirements under DoddFrank make Hong Kong attractive. See Timothy Geithner, Macroeconomic Effectsof Risk Retention Requirements, 2011, available online.

${ }^{279}$ In the US context, when an originator in California passes off all the risks of an asset-backed security to investors in New York, the US as a whole still faces systemic risk. However, if originators in Hong Kong pass off these risks to investors in Mexico (for example), we externalise these systemic risks. Thus, Hong Kong is in the enviable position of passing off risks which fragilise foreign economies, while reaping the benefits of fat securitisation fees and commissions.

${ }^{280}$ Academics from all disciplines remain highly critical of Dodd-Frank and its effect on the competitiveness of the US financial services industry. For one of the many examples of such analysis, see David Batty, Dodd-Frank's Requirement of Skin in the game for Asset-Backed Securities May Scalp Corporate Loan Liquidity, 15 N.C. BANKING INST. 13, 2011.

${ }^{281}$ For a review of these kinds of advertising and the broader economic principles of advertising in all sectors (including financial services), see Kyle Bagwell, The Economic Analysis of Advertising, 2005, available online.

${ }^{282}$ In Hong Kong for example, the Securities and Futures Ordinance requires that the SFC "provide protection for members of the public investing in or holding financial products.” The Ordinance also
} 
"informative” and "complementary" advertising actually allow investors to identify investment opportunities and participate in them. Numerous studies have shown that the informative advertising of financial services creates value and reduces investors' dissatisfaction with their investments. ${ }^{283}$ Many authors have noted that strong incentives exist in the financial services to engage persuasive advertising which adds no particular value - and may destroy by encouraging investors to purchase high risk - low return investments. ${ }^{284}$ Fortunately, at least in the US, regulators have increasingly relaxed rules on financial services advertising.

The JOBS Act allows for advertising which helps better match investors' needs with investment products. Under the Act, private companies - like many of the solar companies reviewed earlier in this paper - can directly advertise to "accredited investors" and "qualified institutional investors" (who receive this designation because of their selfidentified desire to receive such advertisements). ${ }^{285}$ The Act and related SEC rules have three effects in promoting the development of information markets in sunrise industries. ${ }^{286}$ First, general solicitation (in newspapers, on the internet, in public speeches and so forth) is now allowed. Solar companies like Yingli can put up posters in Times Square (New York) saying "Buy 100 shares of Yingli and Reduce Your Reliance on Coal Electricity." 287 Second, SEC rules look poised create a class of accredited investors able to receive advertisements about solar (and other) investment opportunities. ${ }^{288}$ Overtime, a group of "accredited investors" will expand - creating an expanded class of investors, but still not providing information to the broader public as originally hoped. ${ }^{289}$ Third, regulators seek to create public markets in information by requiring companies to report

requires the SFC to "promote understanding by the public of financial services including the operation and functioning of the securities and futures industry" - but not understanding of particular products or industries. Such objectives clearly encourage the SFC to focus on the risk-side of securities advertising without much regard for the return-side of such advertising. See Securities and Futures Ordinance, at sec 4.

${ }^{283}$ See Simone Wies, Arvid Hoffmann, Jaakko Aspara, and Joost Pennings, Shareholder Complaints and Advertising Investments, 2014, available online.

${ }^{284}$ Mutual funds in particular represent an area where academics have found advertising probably destroys rather than creates value. See Alan Palmiter and Ahmed Taha, Mutual Fund Performance Advertising: Inherently and Materially Misleading? GEORGIA L. REV., 2011, available online. See also Bruce Huhmann and Nalinaksha Bhattacharyya, Does mutual fund advertising provide necessary investment information?, 23 INT’L J. OF BANK MARKETING 4, 2005.

${ }^{285}$ For more, see Larissa Lee, The Ban Has Lifted: Now is the Time to Change the Accredited-Investor Standard, UTAH L. REv. Forthcoming, 2014, available online. At the time of this writing, individuals (and institutions) receive such status because they have identified themselves to the advertiser or an intermediary whom the advertiser relies on when obtaining the lead's contact information. Accredited investors usually sign a declaration saying they met the criteria of an accredited investor without providing any supporting documents or proof of their assets or income.

${ }^{286}$ The legislative history of the JOBS Act indicates that such advertisements clearly aim at encouraging the development sunrise industries (which consist of small companies looking for capital to expand). As US President Barrack Obama said, at the Act's signing, the Act will allow "startups and small business[es to] ... have access to a big new pool of potential investors, namely, the American people.” Remarks on Signing the Jumpstart Our Business Startups Act, 2012 DAILY COMP. PRES. DOC. 1, 2012.

${ }^{287}$ Companies can solicit to the public, but only sell to "accredited investors."

${ }^{288}$ See Securities and Exchange Commission, Eliminating the Prohibition Against General Solicitation and General Advertising in Rule 506 and Rule 144A Offerings, File No. S7-07-12, available online.

${ }^{289}$ For an analysis of the SEC's rules on “accredited investors”, see The SEC's JOBS Act Rulemaking:

What It Means for Private Fund Managers, 2013, available online. 
to the SEC such public advertising. ${ }^{290}$ In this way, advertisements -- and the valuable information they contain -- can not stay within a limited group of persons.

Yet, the JOBS Act (and its amendments of US securities law) still misses the point. First, new rules allowing general solicitation to the public will likely encourage potentially harmful "persuasive" advertising, rather than the constructive "informative" and "complementary” advertising.” Nothing requires companies and financial intermediaries to post educational Ogilvy-style ads rather than BDDP \& Fils racy ones. If "persuasive" advertising of structured products and asset-backed securities contributed to the 2008 financial crisis, then "informative” advertising could have helped mitigate it. ${ }^{291}$ Second, regulators and academics still wrongly view any definition of "accredited investors" as revolving around their wealth or income. Lee for example, proposes to strengthen the current principles-based accreditation procedure by using metrics like the investors' financial sophistication, wealth verification, diversification, and upfront disclosures. ${ }^{292}$ Instead, policymakers should look at investors' need for asset-backed securities. Do they help the investor understand the market or the assets (for example a coal producer buys solar-backed bonds in order to see how they perform before making large-scale investments in solar energy)? Do their price movements help hedge other parts of the investors' portfolios (we showed in a previous section that Mainland solar asset's value correlate negatively with the Japanese stock market). Such US financial law defects represent an opportunity for Hong Kong.

While Hong Kong law is pretty relaxed about advertising investments, such law clearly does not encourage the kind of "informative" advertisement we think will make Hong Kong a competitive international financial centre for sunrise industries. In general, advertisements abroad - which as we have argued represent the majority of sunrise industries' “catchments area” -- naturally fall within other countries' jurisdiction. ${ }^{293}$ The regime covering the sale of Hong Kong securities to Hong Kong residents remains as restrictive as anywhere in the developed world. ${ }^{294}$ Companies and investment advisors can not put material from a prospectus in an advertisement. ${ }^{295}$ Exceptions include material authorised by the SFC, which informs the viewer of the listing applicant to which the advertisement relates, warns potential investors to read the prospectus, and states that the advertisement does not constitute an offer or an invitation to buy

\footnotetext{
290 See Securities and Exchange Commission, Amendments to Regulation D, Form D and Rule 156, FILE No. S7-06-13, available online.

${ }^{291}$ Wide-spread evidence shows that asset-backed asset offerers and structured product sellers relied on increasing the complexity of their securities as a way to reduce competitive pressures in their sector. Clearly, such complexity could not exist in a market where investors have become used to clear and informative advertising and product information. See Claire Cererier and Boris Vallee, What Drives Financial Complexity? A Look into the Retail Market for Structured Products, available online.

292 See Larissa Lee, The Ban Has Lifted: Now is the Time to Change the Accredited-Investor Standard, UTAH L. REV., Forthcoming, 2014, available online.

293 The Securities and Futures Ordinance excludes foreign advertising from registration. See Securities and Futures Ordinance, at 103(3)j.

${ }^{294}$ Sections 103 to 106 of the Securities and Futures Ordinance provide an extensive list of do’s and don't for advertising securities, as well as the types of securities and persons potentially excluded.

295 See Companies Ordinance, at 38B
} 
securities. ${ }^{296}$ Like in most places, Hong Kong law generally allows the giving of investment advice in public media - allowing for specific recommendations contained in sites like Seeking Alpha or Motley Fool. See Securities and Futures Ordinance at Schedule 5(ix). Yet, as briefly discussed in Figure 55, Hong Kong lacks an Englishlanguage information source for Hong Kong and Mainland shares. ${ }^{297}$ Without a vibrant English-language financial press that reports company-level (and even asset-level information), Hong Kong will have a hard time catching up with New York and London. $^{298}$

\section{Figure 55: Why Doesn’t Hong Kong Have Its Own Jim Cramer?}

Jim Cramer, the host of CNBC's Mad Money, represents a uniquely American phenomenon. Every day, his show and other fora (like TheStreet.com) provide TV viewers and internet readers with very specific stock picks. Such picks clearly solicit interest (long or short) in specific shares. What makes Jim different from the CEOs of these companies? Or you and I? In other words, why does US law allow for - and obviously encourage - advertisements in specific shares (even before the JOBS Act)? Maybe Hong Kong locals may not tune into a Hong Kong version of Mad Money - but what about the millions in the US and EU with an interest in Mainland (and Hong Kong) shares? Hong Kong law may not prohibit a local Jim Cramer - but it neither provides strong incentives for others to replicate Mr. Cramer's stock picking media empire around the China South Sea.

Hong Kong's regulatory response has been the tighten regulations around advertising investments - rather than let the disinfecting sunlight of transparency do its work. The Code on Unlisted Structured Investment Products reflects this approach. The Code provides numerous requirements to provide warnings to investors. ${ }^{299}$ Yet, the Code mentions nothing about encouraging intermediaries to provide ideas about such investments that could contribute to a well-balanced portfolio. Under the rules, any such ideas might be considered as "contain[ing] language, artwork or graphics that is inaccurate or inconsistent with the offering document for the relevant structured investment product.” Reforms which make advertising structured products more

\footnotetext{
${ }^{296}$ See Companies Ordinance at Schedule 19.

297 Bloomberg, Wall Street Journal, Reuters and other international media organisations work in Hong Kong. However, their coverage of Hong Kong companies pales in comparison to their US coverage. A simple look at Bloomberg’s Hong Kong page shows much of the "news” about market aggregates and macro-economic data from across Asia.

298 The evidence clearly shows that adopting English has very positive effects on portfolio investment. While some of this preference reflects a "home bias" by native English speakers, much of the effect comes down to English's pivotal role as the language of international financial media (and thus source of learning about investment options). See Zoran Ivkovic and Scott Weisbenner, Information Diffusion Effects in Individual Investors' Common Stock Purchases: Covet Thy Neighbors' Investment Choices, 20 REV. FIN. STUD. 4, 2007. See also Thomas Jeanjean, Herve Stolowy, Michael Erkens \& Teri Yohn, International evidence on the impact of adopting English as an external reporting language, 45 J. OF INT'L BUS. STUD. 5, 2014.

${ }^{299}$ See Code on Unlisted Structured Investment Products, at Appendix D (Advertising guidelines applicable to unlisted structured investment products).
} 
difficult deprive investors of the information they need to protect themselves from the abusive marketing practices committed during the Minibond episode.

\section{Arranging for collections against Mainland collateral}

Nothing about Hong Kong's law makes it a particularly friendly (or unfriendly) jurisdiction for securitising assets. Hong Kong follows UK law - giving direct effect to UK cases before 1997 and following legislative developments closely since that time. In HKSAR v Ma Wai-kwan and others (29 July 1997), the Hong Kong Court of Appeal decided that the common law and rules of equity of England which applied in Hong Kong on 30 June 1997 continue to apply in the HKSAR, subject to their independent development. ${ }^{300}$ Yet, as much of the collateral for the securitised transactions that rely on the Ma Wai-kwan et al. ruling will likely physically rest in other countries. What issues does this pose for Hong Kong as an international financial (and securitisation) centre?

Given weaknesses with China’s legal framework governing securitization, “importing” Hong Kong law through cross-border securitisation appears the best option for the international sale of Mainland solar securities. China has made efforts to develop the legal framework around the securitisation of assets and income streams deriving from those assets. ${ }^{301}$ Yet, Mainland law remains extremely non-conducive toward such securitisations. ${ }^{302}$ Following Faleris, we also think that cross-border securitised transactions provide the most likely vector for developing the Mainland's securitised asset market - and promoting broader securities market development in general. ${ }^{303}$ The solar industry represents the perfect already-made sector with its own group of specialised international investors. ${ }^{304}$ Moreover, since China lacks laws to govern such securitisation, importing law from Hong Kong can help reduce uncertainty around the assignment of rights and risks - at least at the securitisation stage.

Depending on the way the originators structure the securitisation, the property rights enshrined in the securitisation instruments passing through the hands of Hong Kong's

\footnotetext{
${ }^{300}$ See Kingsley Ong and Annie Lam, Chapter 20: Hong Kong, In The International Comparative Legal Guide to Securitisation 2011, available online.

${ }^{301}$ See Yuwa Wei, Asset-Backed Securitization in China, 6 RiCH. J. GLOBAL L. \& Bus. 225, 2007. See also Mimi Hu, Developing Securitization Laws in China, 27 REV. BANKING \& FIN. L. 565, 2008.

${ }^{302}$ We do not discuss and analyse specific points of Mainland law, in order to keep this paper at a reasonable length. For the reader interested in a detailed - though succinct - analysis of the major issues, see Roy Zhang and Ma Feng, Chapter 12: China, International Comparative Legal Guide to Securitisation 2013, available online.

${ }^{303}$ See Nicholas Faleris, Cross-Border Securitized Transactions: The Missing Link in Establishing a Viable Chinese Securitization Market, 26 Nw. J. INT'L L. \& BUS. 201, 2006.

${ }^{304}$ Farleris specifically argues that "rather than attempting to both build an infrastructure and attract asset-backed securitization investors with large, sweeping changes, the market would be better served by building up the securitization infrastructure gradually and by developing a core group of regional investors at the same time." He specifically seeks to implement his plan with a set of state-owned enterprise assets. However, even the causal reader can see his approach (and argument) would be more effective if he had framed it in terms of a specific industry like solar. See Id. at 202. See also Id at V.5.
} 
international financial institutions may fall into one or more jurisdictions. ${ }^{305}$ Figure 56 provides an example of the way that various rights, returns and risks flow in the crossborder sale of Mainland asset-backed solar securities to foreigner investors (like US investors). ${ }^{306}$ We use techniques from a branch of economics known as New Institutional Economics, to determine how risks and returns "attach" to various institutions. The figure shows each step of the securitisation process, the contracts involved and the risks involved (in green below each step). As the number of contracts and jurisdictions involved in them increases, the higher the amount of risk inherent in the security. ${ }^{307}$ Cross-border securitisation thus tends to increase risks without providing a way of making the underlying assets any more productive. As such, the development of deep markets for sunrise industry securitisations will rely on finding cheaper and less risk-introducing contractual methods of creating asset-backed securities.

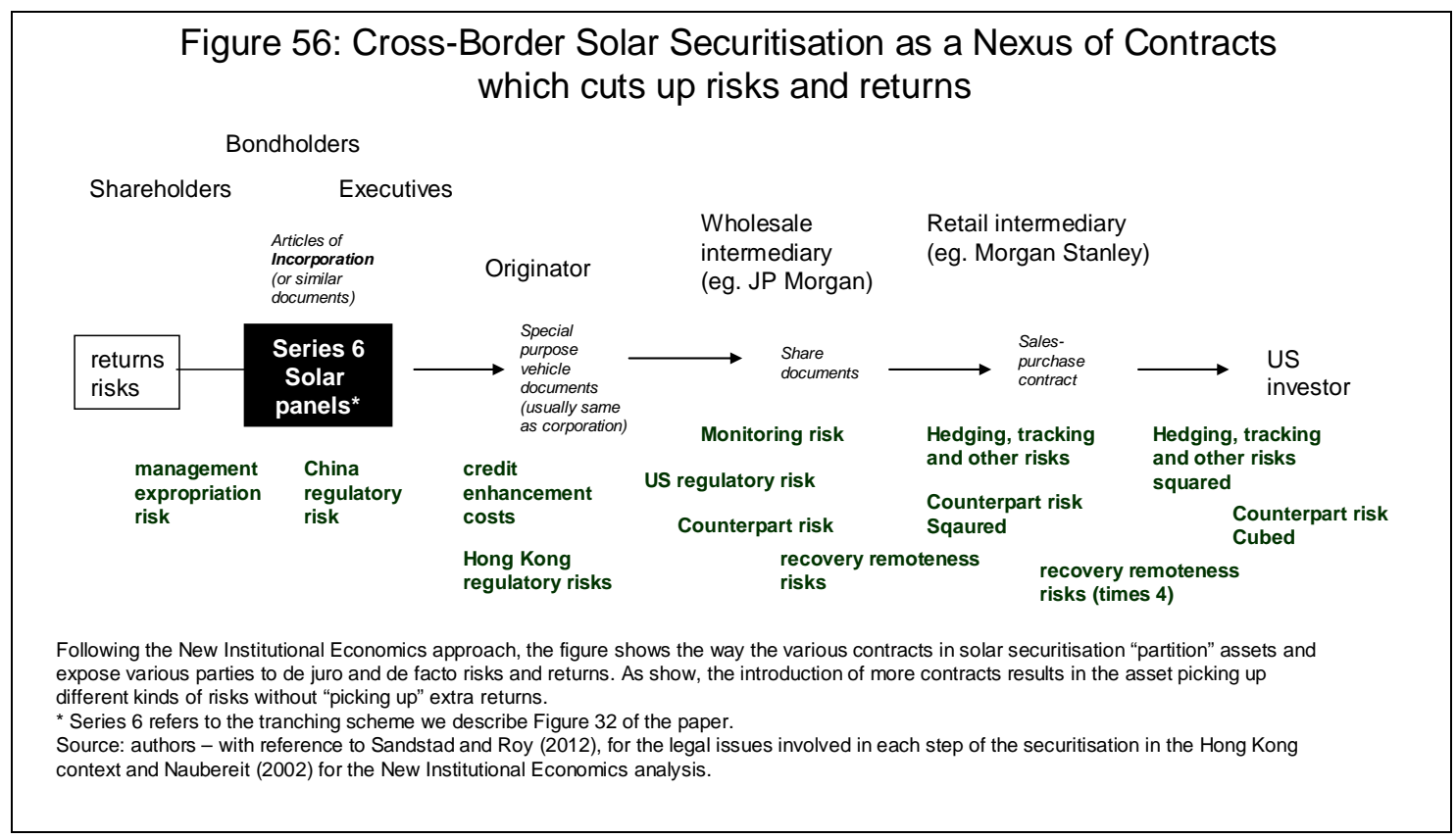

The major legal issues affecting the assignment of rights (and risks) relates to the Mainland's law on “true sale” and Hong Kong’s law on “equitable assignment.” Combined, both issues reduce final investors’ rights over solar assets - particularly in case payments stop for any reason. Related to the issue of true-sale, final investors could find out that the solar-backed securities they hold never held legal title to the solar panels

\footnotetext{
305 The instruments underpinning a securitisation represent a method of allocating property rights over the securitised assets. Interestingly, new institutional economists -- the branch of economics best equipped to analysis how these contracts assign rights and obligations - have conducted few studies of the way the assignment of residual rights to these assets affects contract performance (and the way law enforcement and national traditions affect the value of those rights). For one study, see Philipp Naubereit and Sonja Gier, An Institutional Economic Analysis of Securitization in Real Estate, 2002, available online.

${ }^{306}$ We provide only a summary of the process, with a focus on the aspects of securitisation relevant for our discussion. For a broader background, see Jacob Gyntelberg and Eli Remolona, Securitisation in Asia and the Pacific: implications for liquidity and credit risks, BIS QUART. REV., 2006, available online.

${ }^{307}$ For deeper discussion, see Tamar Frankel, Cross-Border Securitization: Without Law, But Not Lawless, 8 DuKE J. COMP. \& INT'L L. 255, 1998.
} 
(or underlying assets) in the first place. ${ }^{308}$ In Hong Kong's case, equitable assignment means that assets (and income streams) may not "perfectly" pass to final investors. ${ }^{309}$ In both cases, the contractual form chosen may reduce returns to final investors and increase risks. As such, Hong Kong law should focus on ways of reducing the securitisation agency-chains which introduce risk and dissipate returns.

The other major issue concerns recourse to the solar assets (and liabilities) themselves. What happens if these solar panels stop generating (and distributing) income to their residual owners of these property rights in the US? What are these investors' de jure rights over the underlying collateral (and the income itself)? If a key advantage of using Hong Kong as a securitisation centre revolves around its "better" law, what is the likelihood of getting its court orders translated into the Mainland? In general, recognition of foreign judgements - particularly those involving civil claims - remains highly problematic. ${ }^{310}$ While bringing action from Hong Kong may be easier than from the US or EU( for example), such action still remains difficult. ${ }^{311}$

Yet, the desultory number of solar-related disputes in Hong Kong at present makes Hong Kong hardly look like a centre for exercising solar company-related rights. Figure 56 presents several Hong Kong solar-related cases, compared with similar cases in other jurisdictions. These can be divided into four major kinds -- patent infringement, contract disputes, employment disputes and shareholder disputes. Exciting and industry-forming patent disputes comprised only a small part of these civil actions. Only Solarex Corp. v. Arco Solar Inc. and Siemens Solar Industries involved a patent dispute. Lack of significant photovoltaic sector cases suggests that no court has yet risen to play the important industry-forming role it played in sunrise industries like information or biological technology. ${ }^{312}$ Lack of significant litigation of solar industry cases represents an opportunity for Hong Kong to establish itself as a venue-of-choice in this sunrise industry. ${ }^{313}$

\footnotetext{
${ }^{308}$ See Mimi Hu, Developing Securitization Laws in China, 27 ReV. BANKING \& Fin. L. 565, 2008. See also Shengzhe Wang, True SALE SeCuRitiZation: GeRmany AND CHINA, 2007.

${ }^{309}$ In legal language, "perfection" or "perfecting” an assignment relates to passing of legal rights and obligations to the third-party.

${ }^{310}$ See Yuliya Zeynalova, The Law on Recognition and Enforcement of Foreign Judgments: Is It Broken and How Do We Fix It? 31 Berkeley J. OF INT’L L. 1, 2013.

${ }^{311}$ See Jie Huang, Interregional Recognition and Enforcement of Civil and Commercial Judgments: Lessons for China from US and EU Laws, J. OF INT’L PRIVATE L., 2010, available online.

${ }^{312}$ For a discussion of the way court judgments can help determine the development of a sunrise industry, see Bradford Smith and Susan Mann, Innovation and Intellectual Property Protection in the Software Industry: An Emerging Role for Patents?, 71 U. of ChicAGo L. Rev. 1, 2004. See also Polk Wagner, Of Patents and Path Dependency: A Comment on Burk and Lemley, 18 BerKeLEy TeCH. L. J. 1, 2004

${ }^{313}$ The lack of litigation involving asset-based securitisation (or involving the securitisation process in general) represents a more serious concern for policymakers looking to Hong Kong's courts as a venue for establishing the cutting-edge legal doctrines which will define the development of sunrise industries like solar. Only 3 Hong Kong cases emerged from a brief Westlaw search of asset-backed securities cases. In contrast, a cursory search of US federal and state law produced over 2,000 cases.
} 


\section{Figure 57: Solar-Related Court Cases So Far Extremely Uninspiring}

Hong Kong

CEP Ltd. v Wuxi Jiacheng Solar Energy Technology Co. Ltd.

[2014] HKCU 1485

Case involved a dispute over whether the buyer allowed to use a transferable letter of credit to make payment and whether the conduct of the seller's representative constituted waiver/estoppel against seller on the use of transferable letter of credit.

Re Solar Touch Ltd.

[2004] HKCU 751

Creditor asked to wind up C, a BVI incorporated company.

Solar Exports Ltd. v Yick Lee Trading (China) Ltd.

[2003] HKEC 722

Pedestrian case involving a payment dispute.

Mainland

Jiangsu Huaiyin Huihuang Solar Energy Co. Ltd. v Hou Lina

Dispute involving the infringement of the right to use a trademark.

US

Sunearth Inc. and The Solaray Corp. v. Sun Earth Solar Power Co., NBSolar USA and Does 1-10

Trademark and trade name infringement case over the right to the Sun Earth name.

Sybac Solar AG. v. Sybac Solar LLC

German solar energy company sued its US subsidiary for breaching a project agreement.

Gaea Holdings, LLC v. Solar Energy Initiatives, Inc.

Case involved dispute over an independent consulting agreement

Ray Angelini, Inc., v. SEC BESD Solar One and others

Ray Angelini Inc. alleged non-payment for services performed.

Michael Oberstein v. Sunpower Corp. and others.

NYSA used exclusively SunPower solar PV components in exchange for marketing, advertising, and

SunPower's work developing local markets. Later claimed Sunpower did not do enough to promote

business in the area.

GT Solar Incorporated v. Fabrizio Goi

GT Solar Incorporated sued Fabrizio Goi for obtaining confidential information about GT Solar's manufacturing process and sharing it with GT Solar's California-based competitor.

Arkansas Public Employee Retirement System et al. v. GT Solar International, Inc. et al.

An investor (Arkansas Public Employee Retirement System) who purchased GT Solar shares in the IPO sued the company for losses in share price of $24 \%$. The investor claimed GT Solar's promoters failed to disclose in its offering documents the "substantial likelihood" that GT Solar's biggest customer would stop buying its furnaces from GT Solar (which it did stop).

Siemens Solar Industries v. Atlantic Richfield Co.

Siemens Solar Industries bought a company manufacturing thin film silicon (TFS) technology. The buyer later found out the technology was not commercially viable and abandoned production. The buyer claimed the seller did not inform them sufficiently well about such a possible production stoppage.

Solarex Corp. v. Arco Solar Inc. and Siemens Solar Industries, LP.

Solarex Corp claimed Arco Solar Inc. and Siemens Solar Industries violated its patents.

Invenergy Solar Development v. Gonergy Caribbean SARL and Yazid Aksas

Gonergy Caribbean SARL and Yazid Aksas agreed to buy Invenergy Solar Development. When the acquirers found out the potential acquiree's projects were not commercially viable, the acquirer tried to cancel the sale. The acquirees wanted development fees the acquirer promised.

MEMC Electronic Materials Inc. et al. v. BP Solar Internatioonal Inc.

Case revolved around whether one of the company actually purchased silicon powder.

Solar Cells Inc. v. True North Partners LLC, First Solar LLC, Michael J. Ahearn, Michael L. Pierce and Michael Gallagher.

Shareholders objected to a merger which diluted their share of one of the pre-merger companies.

Source: Westlaw (2014). 
How can Hong Kong law help promote the production of enforceable judgements regarding Mainland solar assets? If Hong Kong will develop as a venue-of-choice for securitising solar assets, investors must be able to sue Mainland solar companies in case of problems. They must know the courts will act - and should have recourse to Hong Kong's courts in case Mainland courts provide little assistance. The 2006 Arrangement on Reciprocal Recognition and Enforcement of Judgments in Civil and Commercial Matters represents a first step in this direction. ${ }^{314}$ Figure 58 shows the major provisions from the Agreement. In theory, US investors looking to sue a non-listed Mainland company like Zhejiang Firstar Panel Tech (for non-payment of promised payments under a securitisation claim) may use Hong Kong courts to try and enforce the judgement (particularly if they agreed to Hong Kong as the venue-of-choice). Yet, only one case has so far mentioned the Arrangement. ${ }^{315}$ Improving the arrangement will rely on proactive government support.

\section{Figure 58: Overview of the Reciprocal Recognition and Enforcement of Judgments in Civil and Commercial Matters Arrangement}

\section{Article $\quad$ Topic covered}

Article 1 Power to seek recognition of foreign court's judgment

Article 2 Definition of "enforceable final judgment"

Article 3 Definition of "choice of court agreement in writing"

Article 4 Place to apply for recognition

Article 5 Standing in case defendant lives/works in more than one province

Article 6 Documents plaintiff needs to submit (application)

Article 7 Information needed in application

Article 8 Application of local law during application proceedings

Article 9 Conditions mitigating (stopping) any recognition/enforcement

Article 10 Proceeds on applications during an appeal

Article 11 Equivalence in effect for court recognising application

Article 12 Procedure for appealing a decision based on an application

Article 13 No opening settled cases or using more than one jurisdiction (court)

Article 14 Authorisation to freeze assets in case of

Article 15 Payment of enforcement fees/costs

Article 16 Power to include interest, lawyer fees, and litigation costs

Article 17 No applications about judgement made before arrangement comes into effect

Article 18 Dispute resolution (between Mainland and Hong Kong authorities)

Article 19 Date the Arrangement starts

What can't the Government do to improve knowledge about, and the use of, the Agreement in improving the settlement of potential disputes around securitised assets (like solar-backed securities)? The Government established the Financial Dispute Resolution Centre specifically in response to poorly functioning securitisation markets -

\footnotetext{
${ }^{314}$ See Arrangement on Reciprocal Recognition and Enforcement of Judgments in Civil and Commercial Matters by the Courts of the Mainland and of the Hong Kong Special Administrative Region Pursuant to Choice of Court Agreements between Parties Concerned, 2006, available online.

${ }^{315}$ See Chengdu Transportation Construction Development Co., Ltd. Thailand v. Neo-China Land Group Ltd., [2013] HKCU 51.
} 
as epitomised by the Minibond scandal. ${ }^{316}$ Investors dealing with cross-border solar securitisations will likely prefer Hong Kong's financial dispute resolution scheme to the Mainland's. ${ }^{317}$ The non-regulatory nature of the Centre makes its serious functioning unlikely. ${ }^{318}$ Lack of public information about the Centre's proceedings make using its deliberations as the basis for setting solar-securitisation policy unlikely. ${ }^{319}$ Mediation and arbitration decisions do not accrete into legal doctrines in the same way that case law does -- making the Centre a substitute rather than complement to court-based litigation. Such critiques are not new. Most proposals aimed at improving the US's (and to a lesser extent the UK's) dispute resolution framework focus on increasing the transparency of the process and releasing more information about these disputes. ${ }^{320}$ The development of alternative (non-judicial) dispute resolution stunts the development of an internationally competitive financial law which can attract various parties to solar securitisations. ${ }^{321}$

What can the Hong Kong Government do to encourage the development of Hong Kong as a venue-of-choice in deciding the law of solar-securitisation? In line with our thesis, open-access information about investment disputes (including disputes about solarbacked securities) best allows investors to decide on the risks and mitigate them. The Financial Dispute Resolution Centre should have to publish information about all disputes, including the financial equivalent value of money concerned (though not the outcomes). Improving the arrangement will rely on pro-active support from the Department of Justice, working in collaboration with the Financial Services Development Council. We describe this in the Appendix.

\section{Conclusion}

An international financial centre represents a technology for bringing money to new (and existing) tastes and technologies. Yet, somehow, financial regulators and policymakers have lost sight of that fact. In this paper, we have illustrated numerous mismatches between the supply of, and demand for, funds in China's solar industry. Financial law -

\footnotetext{
${ }^{316}$ See SFC, Memorandum of Understanding, available online. See also Terms of Reference, available online. For a popular media discussion of the Centre, see Enoch Yiu, Hong Kong mediation centre aims to end Lehman minibonds investor pain, SCMP 20 MAY, 2013, available online.

${ }^{317}$ See Robin Huang and Shahla Ali, Governing Financial Disputes in China: What Have We Learned From the Global Financial Crisis of 2008, 7 E. ASIA L. REV. 195, 2012.

Governing Financial Disputes in China: What Have We Learned From the Global Financial Crisis of 2008;

${ }^{318}$ See Shahla Ali and Antonio Da Roza, Alternative Dispute Resolution in Financial Markets - Some More Equal than Others: Hong Kong's Proposed Financial Dispute Resolution Centre in the Context of Experience in the UK, US, Australia and Singapore, 21 PAC. Rim L. \& PoL. J. 3, 2012. See also Shahla Ali and John Kwok, After Lehman: International Response to Financial Disputes - A Focus on Hong Kong, 10 RichMOND J. OF GLOBAL L. \& BuS. 2, 2011.

${ }^{319}$ If the Centre provided extensive information about disputes mediated and arbitrated through its good offices, policymakers could see emerging issues and respond to them.

${ }^{320}$ For an excellent argument, see Alicia Surdyk, On the Continued Vitality of Securities Arbitration: Why Reform Efforts Must Not Preclude Predispute Arbitration Clauses, 54 N.Y. L. SCH. L. REV. 1131, 2010.

${ }^{321}$ A host of other reasons militate against mediation and arbitration - including thresholds for arbitration under HK\$500,000. See Justin D'Agostino, The Hong Kong Financial Dispute Resolution CentreSpecialist arbitrators required to perform a delicate balancing act?, 2013, available online.
} 
and other policies - supposedly seek to help Hong Kong's financial institutions bridge those gaps. However, the international financial centre's financial law (banking and securities ordinances and subsidiary regulation) have not helped as much as they could. Why not?

A focus on Hong Kong's financial sector - and the law which governs it - has diverted attention away from the industries and consumer preferences which use that financial sector. In this paper, we describe the Mainland solar industry's need for international financing. We describe why asset securitisation represents an important method of obtaining such finance. We also describe how Hong Kong's financial law should adopt to "drape over" tastes for solar funding and new technologies available for providing such funding. We argue that the SFC should modify existing rules -- making informational advertising to solar-company investors easier. We also argue that the HKMA and SFC should promulgate regulations requiring broader dissemination of bond trades as well as information about asset-backed securities. By promoting the development of solar-backed security finance, Hong Kong lawmakers will promote the development of sunrise industries in general - and thus ensure Hong Kong's role as an international financial centre for years to come. 


\section{Appendix I: Solar Company Finance and the Financial Services Development Council's Business Plan}

What can the Financial Services Development Council do to encourage the development of solar securitisation financial services? Throughout this paper, we have argued for five roles for Financial Services Development Council -- assuming the Council becomes the private company it has always intended to become. ${ }^{322}$ First, it can set up and maintain a Mosaic-like website. Second, the Council can help syndicate local English-language versions of sites like Seeking Alpha (HK) and Motley Fool (HK). Third, it can set up a harmonised webcasting platform like the NASDAQ offers so internet users can see investor day presentations, earning calls, annual meetings and other presentations online. Fourth, it can help underwrite the Bauhinia solar fund (which sells pooled solar assets) and participate in the origination of other solar-backed securities. Fifth, it can maintain a database about disputes involving asset-backed securities (and particularly solar-backed ones). These revenue-generating activities supplement its normal role, providing advice on the development of Hong Kong's financial services sector.

\section{The FSDC should provide public goods which make solar securitisation possible}

The Financial Services Development Council (FSDC) represents the organisation best placed to provide many of the public goods needed for the development of a solarsecuritisation centre in Hong Kong. Promoting sunrise industries - and the securitisation of photovoltaic assets and liabilities in particular - represents a public good in three ways. First, once a vibrant market for solar asset securitisations exists, private market actors will face lower costs in establishing their own services. Second, information disclosure represents both a first-mover disadvantage and an experience good (service). Third, investments in English-language services can help reduce switching costs as current local (non-international) financial institutions target ASEAN, US and EU markets. Initial funding for the Council helps pay for initial costs that would be unprofitable for private sector actors to pay in the short-run, but which profit all parties in the longer-run.

\footnotetext{
${ }^{322}$ The original terms of reference for the Council envisioned it as a limited company with its own funding. See Cha et al., Preparatory Task Force's Report on the Setting Up of a Financial Services Development Council, 2012, available online.
} 
Figure A1: Hong Kong Can't (Technically) be an International Financial Centre without Extensive International English-Language Financial Information

A core strategy pushed by the Financial Services Development Council and pundits advising Hong Kong's policymakers all encourage deeper and closer linkages with the Mainland. Gathering more Mainland assets and customers will make Hong Kong a more vibrant international financial centre. Concomitant with that approach has been hiring of Mandarin speakers (and keeping printed materials in Chinese).

At the risk of seeming pedantic, technically, they are not correct. Hong Kong represents a special administrative region in China. Developing Mainland financial service offerings will make Hong Kong a more vibrant domestic financial centre (albeit one in a very vibrant market). By definition, if Hong Kong wants to become an international financial centre, its financial institutions need clients outside of China. And developing these clients requires the lengua franca of the business world - English.

Yet, public investments will need to move Hong Kong's financial institutions (except international ones like Citi and Deutsche Bank to name a few) into using English more widely. Hong Kong financial institutions are locked in - having developed Chinese-language materials and customers. Its cheaper to expand the Chinese Economic Journal, then develop an English language version of a Hong Kong Business Daily. Yet, if these resources already existed, adding to them would only incur marginal costs. The Financial Services Development Council can provide resources for the "sunk costs" needed to make marginal investments in English-language resources less expensive for financial firms.

\section{Establishing and updating the web portal about investments in solar assets}

Why can't Hong Kong copy Mosaic? Mosaic has emerged as the result of a publicprivate partnership. ${ }^{323}$ In the text, we described how displaying asset-backed securities the way Mosaic does can help deepen Hong Kong’s solar securities markets and make investments safer. The Financial Services Development Council -- through a Secretariat -- could help crowd-in investments for asset-backed securities by setting up a Mosaic-HK as a pilot project. ${ }^{324}$ Like Mosaic (and other similar sites), the site can list Mainland solar asset (and liability) securities on offer once the Financial Secretary's Office pushes through the regulatory framework needed for their offer. ${ }^{325}$ The site can show advertisements - both "persuasive" and "informative" (to the extent allowed by law). The site can also charge serious investors for accessing information on a premium basis not visible to the general public. Work on this activity would likely be a part-time job. Once the software is up and running and initial projects are identified and displayed, the site should take care of itself. Specialist staff would need to address complex issues that arise, like tax issues, whether a particular asset can be listed, and so forth. Figure A2 provides the initial budget for this activity. ${ }^{326}$

\footnotetext{
${ }^{323}$ The US Department of Energy put up \$2 million and private investors put up about \$3.4 million in first round funding. Unlike in the case we propose, Mosiac emerged mostly from private initiative. In Hong Kong's case, we propose the public-part of the public-private partnership to go first.

${ }^{324}$ In Arner et al. (2014) we advocate converting the Council into a public body --albeit one still about to earn a profit. The Council would need a Secretariat in order to undertake much of the work we propose in that paper, and in the current paper you are now reading.

${ }^{325}$ Appendix II describes in more detail the complementary regulatory changes needed for legal and successful offer of many of the activities in this section.

${ }^{326}$ Most of the benefits accrue to Hong Kong's banks -- who then pay back part of these benefits as taxes. Yet, we do not calculate the social impacts (costs and benefits) of these activities - as such calculations
} 
Figure A2: Example Budget Plan for Solar Web Portal

\begin{tabular}{|c|c|c|c|}
\hline Item & $\begin{array}{l}\text { Estimated } \\
\text { Number }\end{array}$ & $\begin{array}{l}\text { Amount } \\
\text { (HKD) }\end{array}$ & $\begin{array}{l}\text { Totals } \\
\text { (HKD) }\end{array}$ \\
\hline \multicolumn{4}{|l|}{ Revenue } \\
\hline Project listings & 80 listings & $\$ 10,000$ & $\$ 800,000$ \\
\hline Number advertisements & 450 ads & $\$ 2,000$ & $\$ 900,000$ \\
\hline Investor registrations & 750 regist. & $\$ 500$ & $\$ 375,000$ \\
\hline$\underline{\text { Sub-total }}$ & & & $\$ 2,075,000$ \\
\hline \multicolumn{4}{|l|}{ Expenses } \\
\hline Project staff & 40 days & $\$ 5,000$ & $\$ 200,000$ \\
\hline $\begin{array}{l}\text { Due diligence and specialised } \\
\text { staff }\end{array}$ & 20 days & $\$ 10,000$ & $\$ 200,000$ \\
\hline$\underline{\text { Sub-total }}$ & & & $\$ 400,000$ \\
\hline Expected annual gain & & & $\$ 1,675,000$ \\
\hline
\end{tabular}

The Financial Services Development Council has a particular role to play in setting up a Mosaic-copy cat. First, its contacts allow it to source these projects and offer them on a non-discriminatory basis to both institutional and retail investors. Second, the Council would have more leverage (prestige) than a local company if negotiating with a company like the California-based Mosaic for rights to use the trade name. Third, because this project does not require a full person (and won't generate significant profits), the activity should be done by the quasi-public sector.

\section{Syndicating data to third-party users (like Yahoo) and developing online infomediaries}

A vibrant market for information can help promote the liquidity of solar-backed securities, as well as a range of other securities. Yet, Hong Kong's financial sector lacks far behind in producing data usable by investors and others. A simple search on Yahoo Finance, Google Finance, and even paid services like Reuter's Eikon produces far less information about Hong Kong's companies (and asset-backed securities!) than for their US or UK counterparts. By making initial investments in developing platforms like Seeking Alpha or Yahoo Finance, the Financial Services Development Council can help crowd-in other market actors. Unlike markets for rice or shoes, markets for information goods become deeper and more profitable as they become more widespread.

The economics of establishing a top-tier infomediary echo those of creating a Mosaic-like platform. Figure A3 shows a back-of-the-envelope estimate of the relevant costs and benefits (revenues) of providing information about security prices and investor talk-chat services like Seeking Alpha. The business model shown in the figure differs from the Mosaic-clone site in its scope. The wide scope of this service can help crowd-in demand for solar-backed assets as well as other assets.

would likely excite controversy and detract attention away from the business model itself. Thus, the benefits we estimate certainly and largely under-estimate the value of such a service. 
Figure A3: Creating English-Language Infomediaries Generates about HKD\$14 million

\begin{tabular}{|c|c|c|c|}
\hline Item & Number & $\begin{array}{l}\text { Amount } \\
\text { (HKD) }\end{array}$ & $\begin{array}{l}\text { Totals } \\
\text { (HKD) }\end{array}$ \\
\hline \multicolumn{4}{|l|}{ Revenue } \\
\hline Paid content & 600 placements & $\$ 25,000$ & $\$ 15,000,000$ \\
\hline Pay of click ads & 450,000 clicks & $\$ 0.1$ & $\$ 45,000$ \\
\hline \multirow{2}{*}{$\begin{array}{l}\text { Commissions on referrals for } \\
\text { analyst reports etc. } \\
\text { Sub-total }\end{array}$} & 700 referrals & $\$ 2,500$ & $\$ 1,750,000$ \\
\hline & & & $\$ 16,795,000$ \\
\hline \multicolumn{4}{|l|}{ Expenses } \\
\hline Project staff & 250 days & $\$ 5,000 /$ day & $\$ 1,250,000$ \\
\hline Data purchase plans & 365 days & $\$ 10,000 /$ day & $\$ 3,650,000$ \\
\hline$\underline{\text { Sub-total }}$ & & & $\$ 4,900,000$ \\
\hline Expected annual gain & & & $\underline{\underline{\$ 11,895,000}}$ \\
\hline \multicolumn{4}{|c|}{$\begin{array}{l}\text { The Financial Services Development Council's Secretariat could sign syndication } \\
\text { agreements with the relevant data and platform providers in order to get these services off } \\
\text { the ground. Seeking Alpha only has a US-focused service (so far). The Council could } \\
\text { sign a licensing agreement to use the name and HTML code (giving the site its look-and } \\
\text { feel). The Council could also enter into a similar agreement with Yahoo (and possibly } \\
\text { Google) to set up English-language Yahoo Finance and Google Finance sites with data } \\
\text { fed from the Hong Kong Stock Exchange, HKMA and SFC. Similar agreements with the } \\
\text { Exchange, HKMA and SFC would need to obtain access to such information in the first } \\
\text { place. }\end{array}$} \\
\hline
\end{tabular}

\section{Working with the Hong Kong Stock Exchange on webcast syndications}

Webcasts represent an important way that investors (institutional and retail) can interact with the companies they invest in. They also help ensure that institutional investors do not have access to privileged information - as webcasts provide investors of all incomes and locations the same chance to hear the same information. Corporate-IR.net - the platform that many companies use to put their webcasts online - ranks 2,280 out of all websites in the US (and 7,770 in the world). ${ }^{327}$ Nasdaq OMX - which offers corporate services like webcasting - ranks 5,640 in the US and 12,315 in the world. ${ }^{328}$ Nasdaq OMX's technology segment earned about $\$ 400$ million in revenue in 2013 sufficient revenues if a Hong Kong copycat earned even half of that amount.

The Financial Services Development Council can work with local companies and service providers in three ways. First, the Council's Secretariat -- through its participation in a limited liability company - can start offering rudimentary webcasting with simultaneous

\footnotetext{
${ }^{327}$ See Alexa.com at http://www.alexa.com/siteinfo/corporate-ir.net

${ }^{328}$ http://www.alexa.com/siteinfo/shareholder.com
} 
English-language translation in one central location. ${ }^{329}$ Second, the Council can generate content as well as simply act as an intermediary. Indeed, having a Mosaic-like portal, an arrangement with a service-provider like Yahoo for an English version of its Hong Kong finance site, and its own propriety content can develop such information markets. We do not have enough information to cost out this option.

\section{Underwriting the Bauhinia Solar Investment Fund and other securities}

Asset-backed securities sales in Hong Kong require public investment in order to jumpstart this market. As we have shown, securitisations remain low in Hong Kong - and many of the structured products existing in the market focus on speculative (rather than productive) investment. The Financial Services Development Council could work with a financial institution like HSBC (or another) to securitise assets and liabilities of these organisations.

By bearing most of the expenses in the first underwriting of the securities we propose in this paper, the Council could also dictate the structure and targets of these financial services. At present, Hong Kong's financial institutions might be "locked in" to their existing profitable segments. By moving first, the FSDC can sort out the regulatory and market issues of offering solar-backed securities - making marginal market entry less expensive (and thus more profitable). After the Council oversees the first successful securitisations, their marketing and sale, the Council would stop this activity. In that way, the Council does not crowd-out private market actors.

Mainland solar companies hold enough assets and liabilities to create a vibrant market for asset-backed securities in Hong Kong. As we have previously showed, the value of these assets and liabilities come to about $\$ 90$ million. If financial institutions can generate $1 \%$ on the value of these securities in commissions, revenue from this activity would come to about $\$ 900,000$ (before expenses). In all likelihood, expenses would completely

dissipate these revenues. However, the security could be advertised on web portals and in other venue - deepening the market for these services.

\section{Maintaining the database about sunrise industry disputes}

Disputes represent the way that laws and institutions develop. ${ }^{330}$ As we described in the main paper, without public knowledge about these disputes (and the outcome of these disputes), sunrise industries have difficulty developing. Public knowledge about disputes

\footnotetext{
${ }^{329}$ In practice, these events may be available only through the companies’ websites. Nevertheless, the FSDC can host the webcasts - either on its own site or through a company it participates in. We do not have an opinion about whether the FSDC should offer these services as a private company, exist as a public company while holding shares in a private company, or go it alone. Different models for the FSDC have been proposed.

${ }^{330}$ Readers familiar with the "conflict resolution” school of New Institutional Economics will recognise that institutions develop as the accretion of resolutions to previous conflicts. Law (and the institutions it governs) changes as the equilibrium outcome of these conflicts.
} 
in the solar energy sector will have three impacts. ${ }^{331}$ First, a database about these disputes will show how the industry is developing. Second, it will help assure solar companies and investors that an active mechanism is in place for resolving disputes - thus encouraging participation in solar company securitised assets and liabilities. Third, the collection of these disputes (and their solutions) will help create a type of jurisprudence which never arrives at the courts. Legal scholars and analysts can analyse the types of disputes occurring - and propose policies which resolve the underlying factors causing the disputes in the first place. Naturally, the exact information disclosed would need to be agreed with potential users of the system in the first place.

The FSDC can offer three products aimed at promoting the dissemination of information about conflicts in the solar securitisation industry. First, it can help collect such information in a database it could charge money to access. The Council could work with the Financial Dispute Resolution Centre (FDRC) on ways of encouraging people to complain. Such assistance to the FSRC Public assistance can help attract attention to the Council's information products. If the Council is allowed to participate financially in the Centre's profits, sending business to it could also help its bottom line. Second, the Council can sell this information to infomediaries like Westlaw or Lexis-Nexis. Naturally, the information sold would only be what the disputing parties agree to. Third, the market may be big enough to support revenue earned from sessions at Hong Kong's various investors and compliance conferences. The Council can help find speakers, participants and "sub-contract" sessions on solar-industry development and dispute resolution. Revenues from this area - while probably barely recovering costs - would probably also help attract attention to the Council's other information offerings.

Serve as an anchor for Sunrise Industries Promotion Policy

Part of the Financial Services Development Council's work would consist of promoting certain public policies. The Council needs to earn profits to survive. Yet, as a publicprivate partnership, the Council could lobby for market-friendly policies. We have previously argued that the Council should be a public body - with the ability to raise revenue (and without a bail-out guarantee by the Government). What policymaking functions would the Council have in the areas of solar-backed securitisation? Frankel provides 9 suggestions for reforming securitisation markets in general. ${ }^{332}$ We provide these suggestions below - explaining what the Council can do to address this policy area.

\section{Provide loan-level information that investors, ratings agencies and regulators can use to evaluate collateral and its expected economic performance, both at pool underwriting and continuously over the life of a securitization.}

If the Council helps find money Hong Kong versions of a Mosaic, Yahoo finance and other information intermediaries, these intermediaries could provide such information. We show in Figure 50 what such information might look like. We describe in Appendix

\footnotetext{
${ }^{331}$ We do not specify the amount of information disclosed or other details about such a disclosure regime in the main body of this paper. We leave it to regulators and the markets to work this out.

${ }^{332}$ See Alison Frankel, Reforming the Asset-Backed Securities Market, 2010, available online.
} 
II the regulations the Council can lobby for -- which would require this kind of securitylevel disclosure.

2. Make deal documents for all asset-backed securities and structured finance securities publicly available to market participants and regulators.

Ditto (see 1 above).

3. Develop, for each asset class, standard pooling and servicing agreements with model representations and warranties as a non-waivable industry minimum legal standard.

The Council would have a role to play in such stardardised securitisation documents. As we argue in the main paper, the US represents a very heterogeneous securitisation market. In theory, Hong Kong financial institutions could even set up the international template for such agreements -- with leadership from the Council.

\section{Develop clear standard definitions for securitization markets}

By encouraging all securitised assets to appear online (and by encouraging public discussion of these products in fora like a Seeking Alpha-HK), the Council could encourage the market to create such definitions. All asset and liability-backed securities appearing on these websites would clearly comprise the market. Thus, instead of sitting in an Ivy-Tower and dreaming up a definition using legal theory, the Council's information products could encourage markets to develop these definitions for themselves.

5. Directly address conflicts of interest of servicers that have economic interests adverse to those of investors, by imposing direct fiduciary duties to investors and/or mandatory separation of those economic interests, and standardize servicer accounting and reporting for restructuring, modification or work-out of collateral assets.

The Council has two roles. First, the Council would lobby for disclosing such conflicts of interest (using rules which we propose in Appendix II). Second, the Council would encourage the development of the infomediaries (like Mosaic-HK) where conflict of interest declarations could appear along side the offer of the securities themselves.

6. Just as the US Trust Indenture Act of 1939 requires the appointment of a suitably independent and qualified trustee to act for the benefit of holders of corporate debt securities, Hong Kong model securitization agreements could contain substantive provisions to protect asset-backed security holders.

The Council could encourage the development of these provisions through legal advice to the SFC (as we describe in Appendix II). With vibrant and critical discussion of individual securities on websites like a Seeking Alpha-HK or Motley Fool-HK, such 
provisions would become less important. Market actors themselves could police the managers of securitisation trusts. Economic incentives would far more

\section{Asset-backed securities should be explicitly made subject to private right of action provisions of anti-fraud statutes in securities law and to appropriate Sarbanes- Oxley-like disclosures and controls.}

The Council could take the lead in gathering opinions from market actors (both in Hong Kong and abroad) as well as providing a forum for debate/discussion. The Minibond scandal shows the way government activity can work with (and substitute for) private right of action.

\section{Certain asset-backed securities could be simplified and standardized so as to encourage increased trading in the secondary market on venues, such as exchanges, where trading prices are more visible to investors and regulators.}

The Council can encourage the sharing of information (through the websites it helps set up) which makes such exchange-based trading efficient. The Council - through setting up a Mosaic-HK like website and encouraging the legal changes which allow for its operation -- can also help create new exchanges.

\section{Ratings agencies need to use loan-level data in their initial ratings and to update their assumptions and ratings as market conditions evolve and collateral performance is reported.}

The Council's work on developing infomediaries would help supplement the problematic rating agencies ratings. These websites would also contain information and debate about the assumptions and information the rating agencies use to arrive at their rankings. Many critical articles appear on Motley Fool, Seeking Alpha, and other websites of rating agencies’ reports. The Council can encourage such analysis -- without necessarily participating in it itself.

\section{Conclusion}

The Financial Services Development Council can expect to make almost US\$5 million in profits from the activities we describe in this appendix. These funds show that the Council can promote the development of a sunrise securitisation market while still making a profit. Without the Council's participation, these activities seem highly unlikely to develop. Using the Council also fits with the "contingency" approach we describe in the paper -- by finding a need in Hong Kong's financial markets and addressing it at a profit. 


\section{Appendix II: Regulatory Provisions Implementing a Sunrise Industries Promotion Policy}

In recent years, many financial centres have focused on modifying their law to encourage the development of new and innovative industries. The US had its JOBS Act - focusing narrowly on new and innovative industries. The UK's Financial Services and Markets Act (FSMA) establishes a principles-based approach to regulation - letting markets rather than financial law take the lead. Hong Kong's Financial Secretary has convened a Task Force looking at how to make Hong Kong's financial services more internationally competitive ${ }^{333}$ However, no serious policy initiatives have aimed at promoting returns as well as managing risks - of Hong Kong's financial services sector.

In this paper, we have argued for several policies aimed at promoting the securitisation of assets used in sunrise industries like solar energy. First, we have argued for a pro-active policy promulgated by the Financial Secretary's Office for encouraging the development of Hong Kong as a securitisation centre. Second, we have argued for improving the availability of public information about stocks, bonds and asset-back securities offered and traded. Third, we have argued for relaxing SFC requirements - especially governing funding portals and around the "informative" advertising of asset-backed securities in sunrise industries. Fourth, we have argued for increasing information about disputes and about the 2006 Arrangement on Reciprocal Recognition and Enforcement of Judgments in Civil and Commercial Matters and sharing information about financial disputes. To keep our appendix short, we omit discussing the final point.

\section{Outlines of the Policy}

The Financial Secretary's Office needs to promulgate an administrative order (either formally or informally) putting in place provisions of a Sunrise Industries Promotion Policy (SIPP). ${ }^{334}$ Numerous academic authors argue that for a special prudential regulatory scheme for renewable energy - and in our case specifically solar investments. ${ }^{335}$ Moreover, the Financial Secretary's Office (through such a Policy) should coordinate the activity of the HKMA and SFC for several reasons. First, these two institutions are sub-ordinate to the Financial Secretary's Office. Because of their risk adverse nature, they will not take action on the reform-minded proposals we have outlined in our paper without specific instructions from the Government. ${ }^{336}$ Second, the cross-institutional nature of the policy requires the participation of the Financial Services

\footnotetext{
${ }^{333}$ We review these policies in Arner et. al. (2014). We refer the reader to this study so as not to repeat these arguments here.

${ }^{334}$ The Policy serves as an analogue to the US JOBS Act -- with its focus on defining Emerging Growth Companies. We describe the Act and its special regime for sunrise industry companies in the main body of our paper.

${ }^{335}$ See Panagiotis Delimatsis, Promoting Renewable Energy Through Adaptive Prudential Regulation in Financial Services, TILEC DP 2010-017, 2010, available online.

${ }^{336}$ We describe the administrative dependence of the SFC and HKMA in Arner et al. (2014). To briefly recap, the HMKA is subordinate to the Financial Secretary. The SFC is highly attentive (though technically independent).
} 
Development Council, the Hong Kong Stock Exchange, private sector and the regulators (HKMA and SFC). Only the Financial Secretary’s Office has the legitimacy and authority to engage in such a broad-sweeping activity. The HKMA and SFC have extensive delegated rulemaking powers. Thus, only an administratively superiour organisation - like the Financial Secretary's Office - can engage in such coordination.

The Sunrise Industries Promotion Policy should consist of broad instructions to agencies “depending” on the Financial Secretary's Office. Figure A4 shows the major areas contained in the policy document. ${ }^{337}$ The Financial Secretary's Office should define a Hong Kong equivalent to the US JOBS Act's “emerging growth companies” - called sunrise industry companies in Hong Kong (and defined differently). Such a definition would focus attention on these companies - and serve as a pilot for broader coverage. In keeping with the pilot, the easiest thing for the Financial Secretary's Office to do is use the list from the Mainland's $12^{\text {th }}$ Five Year Plan. Such a list makes sense because many of the assets listed in Hong Kong (do and would) come from the Mainland. Second, the Financial Secretary's Office can instruct the HKMA to modify the Central

Moneymarkets Unit webpage. The instruction would likely contain instructions on the types of materials on the site and a requirement that independent evaluation find the site "good" or "outstanding". 338

\section{Figure A4: Financial Secretary's Instructions to HKMA and SFC*}

1. Definition of "emerging growth companies" coinciding with the seven sectors defined in the Mainland's $12^{\text {th }}$ Five Year Plan,

2 Establish a bond and asset-backed securities web portal platform and issue guidelines requiring electronic submission of all asset data in XBRL format,

3. Encourage the SFC to issue a rulebook on Sunrise Industries (including new rules

on funding platforms and advertising, particularly of asset-backed securities),

4. Instruct HKMA, SFC and Financial Disputes Resolution Centre to deal with Mainland counterparts on dispute resolution (and particularly sharing information), 5. Work with Financial Services Development Council and Department of Justice on improving the functioning of the 2006 Arrangement on Reciprocal Recognition and Enforcement of Judgments in Civil and Commercial Matters.

* The SFC while technically independent, still must consult with the Financial Secretary.

\footnotetext{
${ }^{337}$ Unlike other jurisdictions, Hong Kong's financial law relies heavily on principles-based regulation. As such, the Financial Secretary's Office probably needs not (and wants not) to issue very specific instructions. See Bryane Michael, Does Objectives-Based Financial Regulation Imply A Rethink of Legislatively Mandated Economic Regulation? The Case of Hong Kong and Twin Peaks Financial Sector Regulation, available online.

${ }^{338}$ Such a requirement allows the Financial Secretary's Office to delegate decisions over the form, layout, structure and content of the site - while ensuring its market-oriented approach. Such a market-based approach toward defining the site also conforms with the "contingency-based" approach we argue for in the main paper. A "structuralist" view of financial law (a view we disagree with) would require the Financial Secretary's Office to promulgate specific instructions about how the Moneymarkets website should look like.
} 
Several other instructions can promote the rapid development of the Sunrise Industries Promotion Program. First, the Financial Secretary's Office can require the HKMA to issue a guideline to all broker-dealers and asset managers requiring the electronic submission of asset trades in XBRL. This would allow the HKMA (and later by infomediaries) to report bond and securitised-asset and securitised-liability trades in real time. Again, if the HKMA reports such trades on its Moneymarkets site (and keeping with a "contingency" rather than "structuralist" approach), rulemaking should require "good" or "outstanding" assessments of any HKMA platform by a random sample of the portal's users (or preferably an independent evaluation service). ${ }^{339}$ Second, the Financial Secretary's Office can request that the SFC develop a consolidated Rulebook on Sunrise Industries. The Rulebook provide rules for funding portals looking to become automated trading services and/or recognized exchange companies. The Rulebook would also provide new rules encouraging "informative" advertising and other provisions which we describe in the main body of our paper. Third, the policy would request the HKMA, SFC, and the Financial Dispute Resolution Centre to work with Mainland counterparts - as well as report information about disputes brought before the Centre. Because of the international nature of this work, the Financial Secretary has a key "diplomatic" role to play. Finally, the policy can encourage the Financial Services Development Council and the regulators (HKMA and SFC in particular) to work with the Department of Justice on improving the performance of the 2006 Arrangement on Reciprocal Recognition and Enforcement of Judgments in Civil and Commercial Matters. The Financial Secretary represents a political, as well as administrative, office. By using the standard channels for building and communicating political support for the policy, the Financial Secretary's Office can help encourage participation by local banks and other financial services actors.

\section{HKMA Statutory Guideline on Debt and Securities-Backed Instrument Reporting}

Reporting on securities in Hong Kong follows the regulators' current "structuralist" approach to regulation, rather than the "contingency" one we have argued for throughout this paper. ${ }^{340}$ The HKMA's current system for reporting trades is complex and poorly covers asset-backed securities like solar. Ideally, broker-dealers and asset managers should go to one page where they put in trades (or upload trades in a batch from their firm's software) and even see the latest trade information. ${ }^{341}$ Figure A5 shows the webpage for the trade repository - in effect Hong Kong's central resource for reporting asset trades. Instead of providing a simple platform (and accompanying Guideline), the trade repository pages provide links to literally thousands of pages of manuals and

\footnotetext{
339 Their website is located at: https://www.cmu.org.hk/cmupbb_ws/eng/page/wmp0100/wmp010001.aspx

${ }^{340}$ The introduction to the HKMA's Trade Repository webpage provides the general attitude toward such reporting. Following a structuralist mindset of adopting best practice, the HKMA notes, "the reform measures adopted by the international regulatory community include requiring all OTC derivatives transactions be reported to trade repositories (TRs) and all standardised OTC derivatives transactions be cleared at central counterparty (CCP) clearing facilities.” A contingency approach to regulation might start this text by saying, "In order to provide for more efficient markets and trading for investors and companies, the HKMA offers this Trade Repository service."

${ }^{341}$ In practice, traders do not report on trades (given incentives for misreporting). Intermediaries (like superiors or clerical stuff) and independent staff make, confirm and report on such trades.
} 
instructions. ${ }^{342}$ The products currently covered consist of interest rate derivatives and foreign exchange derivatives. The trade repository will require a complete redesign to deal with asset-backed securities like solar-backed bonds and pooled liabilities.

\section{Figure A5: Trade Repository Layout Follows the HKMA's Needs Rather than Market Participants'}
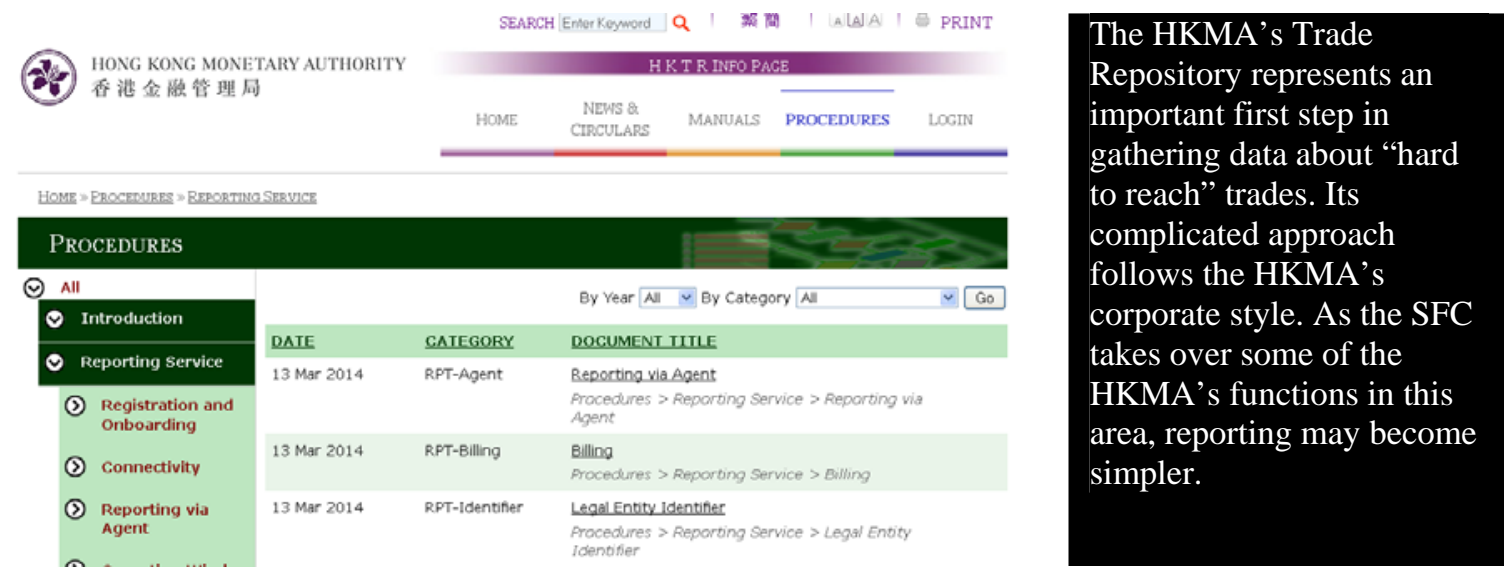

A Guideline governing a debt and securities-backed instrument reporting scheme would cover the general principles we describe in our paper. In some cases, the Guideline can consolidate the voluminous instructions currently provided on the trade repository website. In most cases, the Guideline would need to create new rules for reporting trades in securitised assets and liabilities (both in primary and secondary markets). Except in the case of government and corporate debt, stocks, bonds, and standard derivatives, the Guideline would define who, what, where, when and how to report on these assets. ${ }^{343}$ Also, as shown in Figure A6, he Rulebook would also encourage the distribution of such data to third-party infomediaries. The Guideline would also need to cover how data gets imported from the CMU, CCASS and other exchanges (as relevant). The Hong Kong Stock Exchange's own query tool for finding information about exchange-traded securities is very clumsy. The Trade Repository should not duplicate information contained elsewhere -- unless it presents that information better (more clearly).

\footnotetext{
${ }^{342}$ These instructions revolve around reporting trades (as one major group) and matching/confirmation.

${ }^{343}$ The Central Moneymarkets Unit of the HKMA provides electronic clearing, settlement, and custodian services for Hong Kong dollar-debt instruments. The Hong Kong Stock Exchange’s Central Clearing and Settlement System (CCASS) provides clearing, settlement, and depository services for exchange-traded securities.
} 


\section{Figure A6: Outline Guideline for Debt and Asset-Backed Securities}

Section 1: $\quad$ Objectives of the Guideline

Section 2: "Five Ws" of reporting debt and asset-backed securities (whether traded on exchanges or over-the-counter).

Section 3: $\quad$ Special requirements for persons not trade repository members

Section 4:

Section 5: Methods of reporting for persons already reporting to an exchange

Section 6: Reporting methods for over-the-counter transactions

Section 6: Differences between securitisation reports, trading reports, and "bespoke" transactions

Section 7:

Section 8:

Section 9:

Section 10: The use and reuse of the data you provide Services offered by the HKMA (or its successor)* to help you report Rules governing the third-party distribution of your data Complaints about the collection and use of your data

The relevant working groups on drafting the Guideline will need to tackle a number of issues. First, when registering securities, how to isolate the "bespoke" market from securities destined to be traded on markets. Originators make some asset-backed securities only for a particular buyer (or group of buyers). These securities are sold - but not meant for resale. In addition, as we have previously stated, the HKMA should hire an outside consulting firm to conduct an assessment of the Trade Repository. Figure A7 shows the terms of reference for such an assignment. Following the market-driven approach to regulation (what we call “contingency-based”), such an assessment should focus on users - rather than the needs of the HKMA. Clearly, having a centralised source of information about solar-backed securities can help deepen Hong Kong's markets. An assessment which focuses on final users can only help in achieving that objective. A similar terms of reference can govern a similar assessment of the Moneymarket Unit's website reporting bond trades. ${ }^{344}$

Figure A7: Model Terms of Reference for Independent Assessment of the Trade Repository Interface

The Consultant shall conduct a 20 day assessment of the HKMA's Trade Repository page. The assessment shall focus on the user-friendliness, interactivity and "marketing mindset" of the repository. The assessment must be primarily based on current and potential users of the site and must rely on hard-data (such as surveys, interviews, references to the site and so forth).

Parts of the assessment may include:

a) "look and feel" including how easy it is to use the site, its graphical interfaces, and use by a range of actors,

b) explanatory materials - including their user-friendliness, clarity, helpfulness, and so forth.

c) users' perceptions of the current design - including complaints they have about any part of the service and their suggestions for improving the site,

\footnotetext{
${ }^{344}$ We have already discussed the ways reporting about bond trades in Hong Kong can be improved. No rulemaking needs to be done to change the way the Moneymakers Unit reports about bond trades - as the Unit can engage in such work without an administrative diktat.
} 
As a market-friendliness study, the assessors shall not consider aspects like website security, integration with the HKMA's other systems, the practicality of proposals in light of existing regulations and technical possibilities, difficulties in coordinating with the SFC, and other HKMA capacities. The assessor may have access to the website during the course of the assessment using a guest account which can not post data or access sensitive data on live trades. The HKMA also reserves the right to conduct the engagement in a way which minimises the possibility of using data for the consultant's personal benefit.

Individuals and companies interested in the assignment should submit a short (1 page or less) description how they would conduct the assignment, their budget for this work, and CV(s).

\section{SFC Code on the Electronic Offer of Asset-Backed Securities in Sunrise Industries}

SFC work enabling market platforms for trading solar-backed securities can promote the development sunrise industry financing more generally. In the US, reforms aimed at improving reporting of securities transactions and allowing for greater participation in asset-backed securities investments was couched in terms of crowdfunding. Yet, as we described already, there is no reason why Mosaic needs to focus only on crowdfunding (and relatively small investments). One could just as easily imagine Mosaic containing sections for institutional investors and presenting very large investments in the same simple and clear way it presents small investments in single solar panel investments. While the US JOBS Act may inspire changes in SFC rules governing the offer of assetbacked securities, the Act needs not serve as a rigid model.

The new SFC Code governing investments in asset-backed securities (like solar-backed assets) focuses primarily on promoting "informative" internet advertising (solicitation) as well as the offer and sale of these investments. The Code would achieve two objectives -defining rules of funding platforms and for websites that advertise solar-backed (and other sunrise industry) securities, without offering them. Figure A8 shows the outlines of such a Code. We have provided detailed explanations about how to change existing SFC rulemaking in the main body of our paper.

Figure A8: Outline of the "Sunrise Industries Code"

Section 1: $\quad$ Objectives

Section 2: $\quad$ Definitions (Funding Portal, Crowdfunding Portal, Informative Advertising, Sunrise Industry)

Section 3: $\quad$ Provisions related to the registration of automated trading services and/or recognized exchange companies conforming to the definition of a crowdsourcing portal

Section 4: $\quad$ Types of warnings required on portals

Section 5: $\quad$ Substantive information required on portals and about portals

Section 6: $\quad$ Guidelines for advertising asset-backed securities

Section 7: Definition of "qualified investors"

Section 8: $\quad$ SFC database on funding portals and asset-backed securities

Section 9: $\quad$ Regulations of portal infomediaries 
Each section would enable Mosaic-like websites (and the websites like Seeking AlphaHK which make these websites more useful) to function effectively in Hong Kong. Section 1 -- in keeping with Hong Kong's principles-based regulatory structure -- would define the Code's objectives. As a general principle, securitised solar assets and liabilities should be advertised as clearly as shoes, computers and things consumers can actually tough. Section 2 would define "funding portals" in the context of the Securities and Futures Ordinance's current definitions of “automated trading services” and/or "recognized exchange companies". The section might also provide definitions for the infomediary sites -- like a Seeking Alpha-HK - where investors would discuss publicly listed asset-backed securities. Section 4, in keeping with the SFC's desire to provide warnings, would define the types of warnings that funding portals and infomediaries offering securitised assets and liabilities, would need to post online. Section 5, following the US example, would describe the kinds of information a Mosaic-HK and Seeking Alpha-HK would need to include. Section 6 would define the relaxed requirements for listing and advertising approved securities under the scheme we describe in our main paper. The Code would also provide guidance for providing "informative" rather than simply "persuasive" advertising. We have described the other sections in the main body of our paper.

\section{Conclusion}

Hong Kong's financial institutions will not develop deep and innovative securitised products without help from the Government. In the previous appendix, we described the activities the Financial Services Development Council could undertake to "crowd-in" the development of market infrastructure needed to trade across borders securitised products. In this appendix, we describe the activities the Financial Secretary's Office needs to undertake. Much of such work consists of cheer-leading the HKMA and SFC. The HKMA (and SFC) should revise the way it collects and reports data on securitised transactions. The SFC should create rules which allow for the operation of funding platforms and securitised products infomediaries. 